\title{
EARLY INTERNATIONALIZING FIRMS' CAPABILITIES
}

Classification, configurations, and effects on international performance

Shuijing Jie

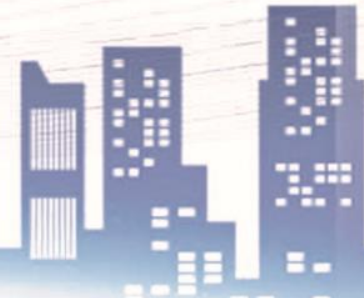




\section{EARLY INTERNATIONALIZING FIRMS' CAPABILITIES}

Classification, configurations, and effects on international performance

Shuijing Jie 


\title{
EARLY INTERNATIONALIZING FIRMS' CAPABILITIES
}

Classification, configurations, and effects on international performance

\author{
DISSERTATION
}

\author{
to obtain \\ the degree of doctor at the University of Twente, \\ on the authority of the rector magnificus, \\ Prof. dr. T.T.M. Palstra, \\ on account of the decision of the Doctorate Board \\ to be publicly defended \\ on Thursday 1 October 2020 at $14.45 \mathrm{hrs}$
}

by

Shuijing Jie

born on the $6^{\text {th }}$ of June, 1991

in Jiangxi, China 
This dissertation has been approved by:

supervisor

Prof. dr. A. Groen

co-supervisor

Dr. R. Harms

Cover design: $\quad$ Shuijing Jie

Printed by:

Ipskamp Printing Enschede

Lay-out:

Shuijing Jie

ISBN:

978-90-365-5060-4

DOI: $\quad 10.3990 / 1.9789036550604$

(C) 2020 Shuijing Jie, The Netherlands. All rights reserved. No parts of this thesis may be reproduced, stored in a retrieval system or transmitted in any form or by any means without permission of the author. Alle rechten voorbehouden. Niets uit deze uitgave mag worden vermenigvuldigd, in enige vorm of op enige wijze, zonder voorafgaande schriftelijke toestemming van de auteur. 


\section{Graduation Committee:}

Chairman / secretary

supervisor:

co-supervisor:

Committee Members prof. dr. T.A.J. Toonen

prof. dr. ir. A. Groen

dr. R. Harms

prof. dr. A. Groen

dr. R. Harms

prof. dr. ir. L.J.M. Nieuwenhuis

prof. dr. M.R. Kabir

prof. dr. R. Breitenecker

prof. dr. J. Halberstadt

prof. dr. T. Flatten

dr. H. Roelfsema 



\section{Table of Contents}

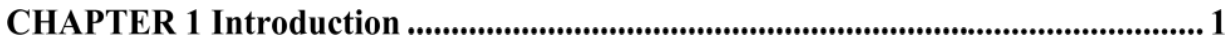

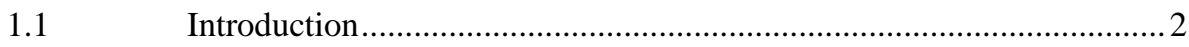

1.2 Theoretical foundation and research questions ................................ 4

1.2.1 Early internationalizing firms ........................................................ 4

1.2.2 CBP and EIFs' international performance ......................................... 5

1.2.3 Alternative perspectives and EIFs' international performance .............. 7

1.2.4 Capability bundles and capability configurations ............................... 8

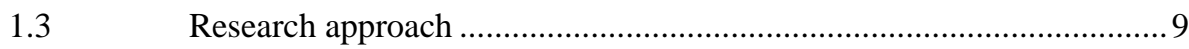

1.3.1 Conceptual research approach...................................................... 9

1.3.2 Empirical research approach ......................................................... 11

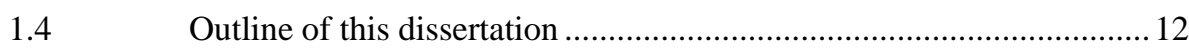

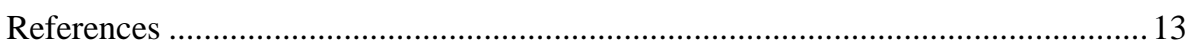

\section{CHAPTER 2 The Development of Research on Chinese Early Internationalizing}

Firms: A Review and Content Analysis ..................................................................... 19

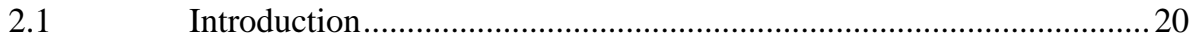

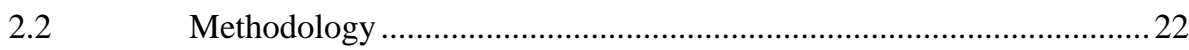

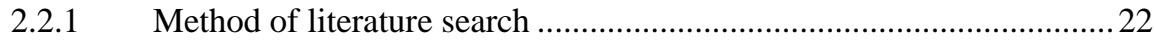

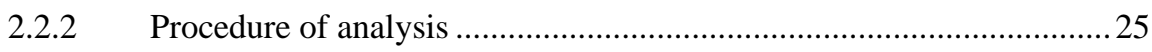

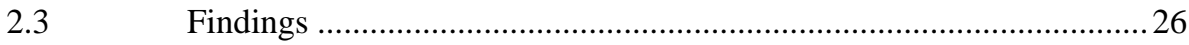

2.3.1 Analyses from antecedents to elements ............................................29

2.3.2 Analyses from elements to outcomes...................................................29

2.3.3 Analyses from antecedents to outcomes ............................................... 31

2.3.4 Analyses on implications of internationalization ................................. 32

2.4 Discussion and implications for future research ............................... 33

2.4.1 Research gaps for studies focus on the Antecedents .............................35

2.4.2 Research gaps for studies focus on the Elements............................... 36

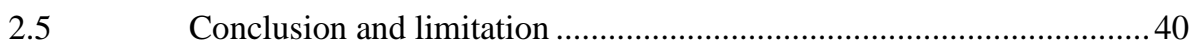

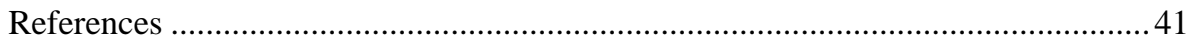

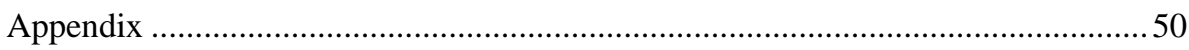

CHAPTER 3 Capabilities and Early Internationalizing Firms' Performance: A Systematic Literature Review .......................................................................................5 53

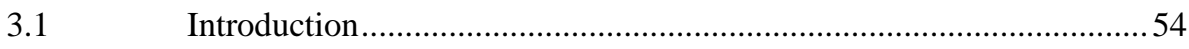

3.2 The theoretical background of the capability categorization model..... 55

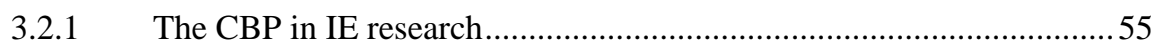

3.2.2 Categorizing substantive capabilities ..............................................57

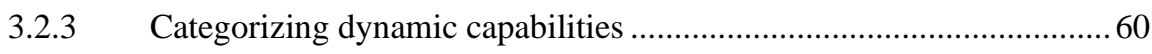

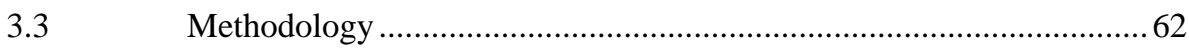

3.3.1 Systematic literature review and its conceptual boundaries................6 62 


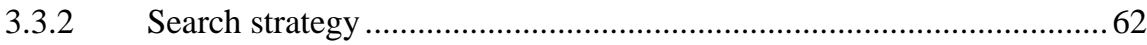

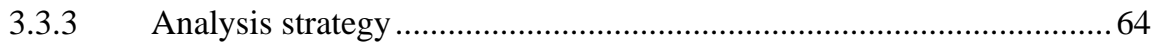

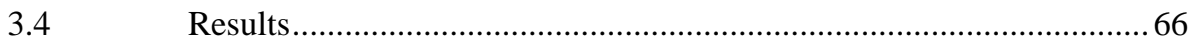

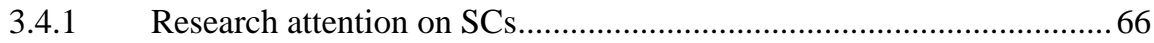

3.4.2 Research attention on DCs .......................................................... 70

3.5 Discussion and future research agenda ............................................ 73

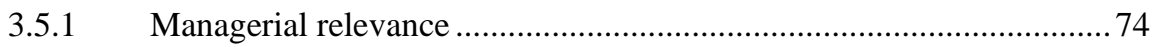

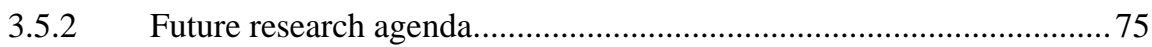

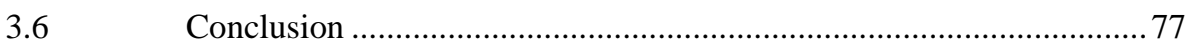

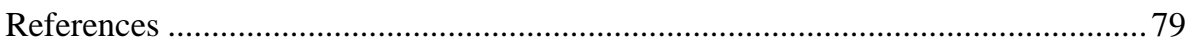

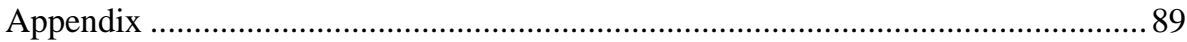

CHAPTER 4 Capability Bundles for International Performance of TechnologyBased Early Internationalizing Firms .................................................................... 91

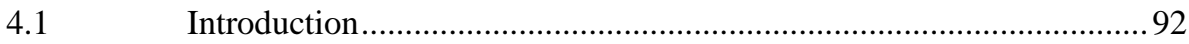

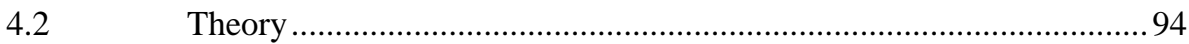

4.2.1 The capability-based perspective ......................................................... 94

4.2.2 The set-theoretic perspective on the capabilities-performance

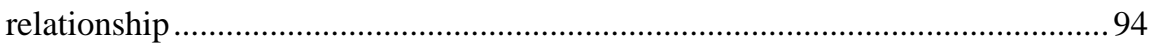

4.2.3 Dynamic bundles and configurations of dynamic bundles.................. 97

4.2.4 Dynamic bundles for international performance................................. 98

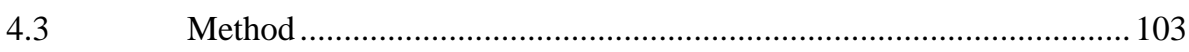

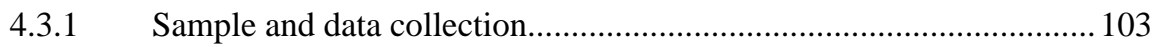

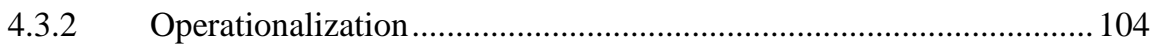

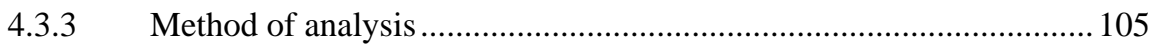

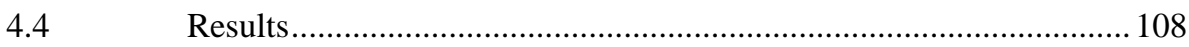

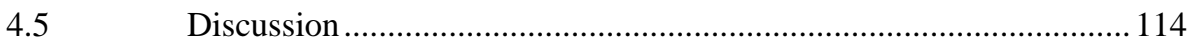

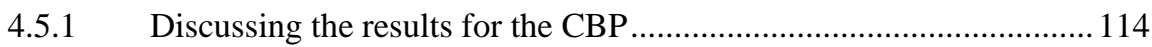

4.5.2 Discussing implications for international entrepreneurship ............... 114

4.5.3 Managerial relevance ................................................................... 115

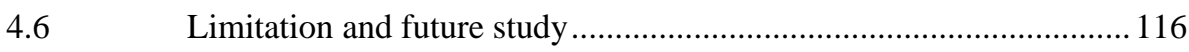

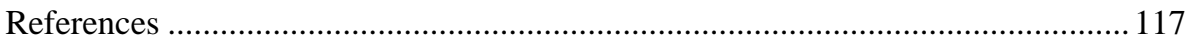

\section{CHAPTER 5 Cross-cultural Competences and International Entrepreneurial} Intention: A Study on Entrepreneurship Education............................................. 127

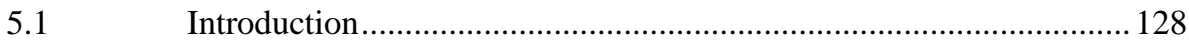

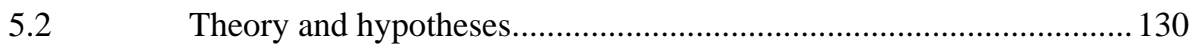

5.2.1 TPB and (international) entrepreneurial intention............................ 130

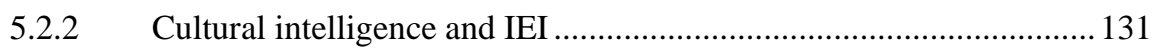

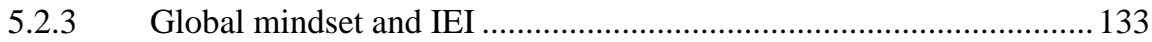

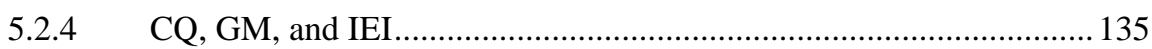

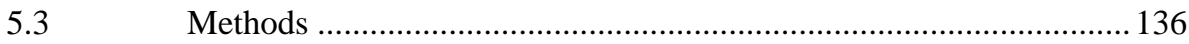




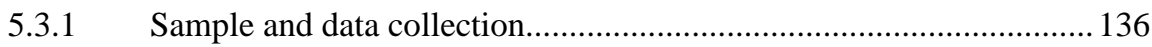

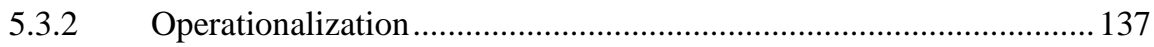

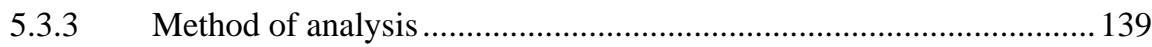

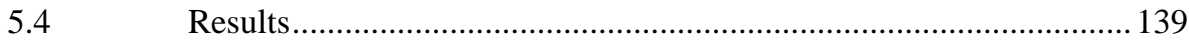

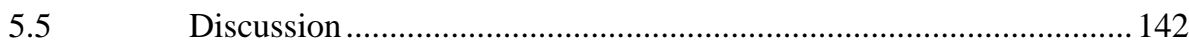

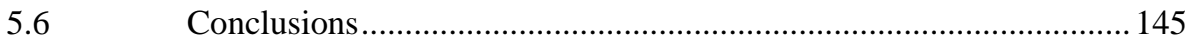

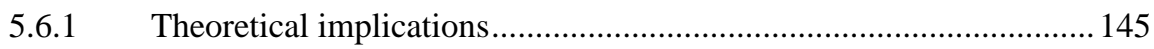

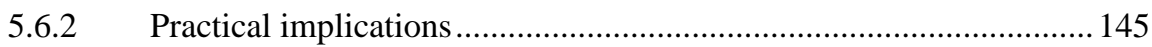

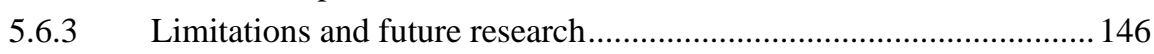

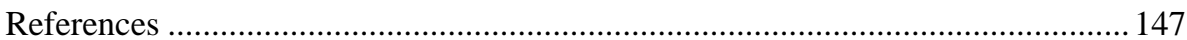

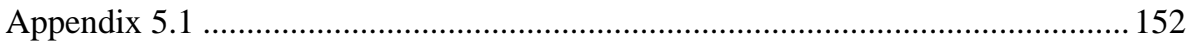

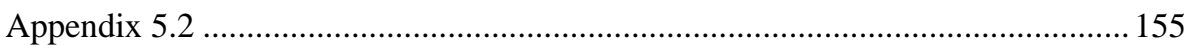

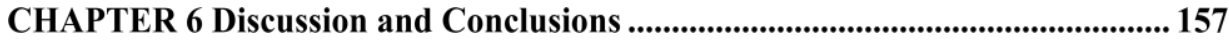

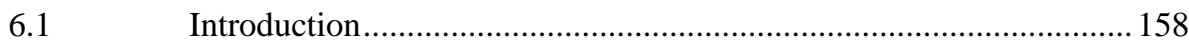

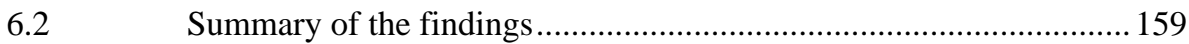

6.2.1 Chapter 2: Research questions, findings, and contributions............... 159

6.2.2 Chapter 3: Research questions, findings, and contributions................. 160

6.2.3 Chapter 4: Research questions, findings, and contributions................ 161

6.2.4 Chapter 5: Research questions, findings, and contributions................ 162

6.3 Contributions to the capability-based perspective.............................. 163

6.3.1 Theoretical implications for the capability-based perspective ........... 163

6.3.2 Future research agenda for the capability-based perspective ............. 165

6.4 Contributions to international entrepreneurship............................... 166

6.4.1 Theoretical implications for international entrepreneurship ............... 166

6.4.2 Future research agenda for international entrepreneurship ............... 167

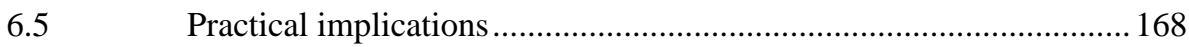

6.5.1 Case analysis on TikTok's capability configurations.......................... 168

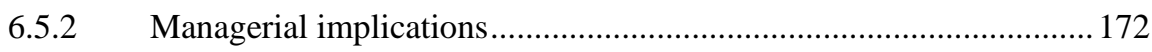

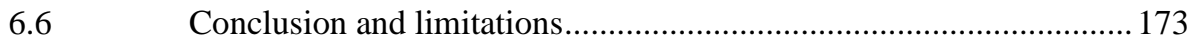

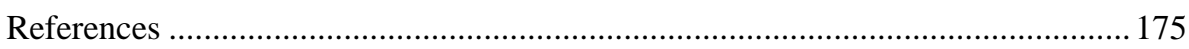

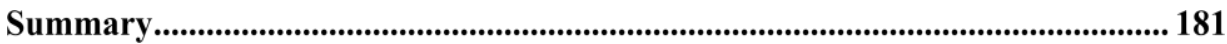

Nederlanse samenvatting (Summary in Dutch)....................................................... 187

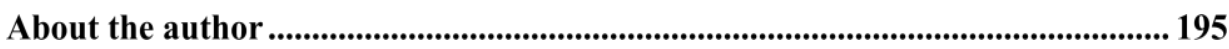

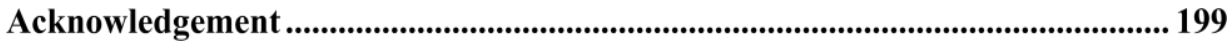




\section{List of Tables}

Table 2.1 Research focus of all reviewed articles. 28

Table 3.1 Capability categories and the distribution. 68

Table 4.1 Sample descriptions $(\mathrm{N}=88)$.

Table 4.2 Operationalization. 106

Table 4.3 Correlations, descriptive statistics, and calibration cut-offs. 107

Table 4.4 Necessary condition analysis results. 108

Table 4.5 Simplified truth table for High international performance. 109

Table 4.6 Capability configurations for High international performance.110

Table 4.7 Simplified truth table for Low international performance. 111

Table 4.8 Capability configuration for Low international performance. 111

Table 4.9 Mean values of condition in each solution. 113

Table 5.1 Reliability statistics of the scales. 138

Table 5.2 Sampling adequacy. 139

Table 5.3 Correlation table. 139

Table 5.4 Direct effects on (international) entrepreneurial intention. 140

Table 5.5 Moderated regression analyses. 141

Table 5.6 Summary results of hypothesis tests. 142 


\section{List of Figures}

$\begin{array}{ll}\text { Figure 1.1 Dissertation outline. } & 12\end{array}$

Figure 2.1 The procedure and result of the systematic literature search. 24

Figure 2.2 Organizing framework of the literature and counts of the most frequent topics treated therein.

Figure 3.1 Performance implications of SCs and DCs along the internal and external dimension.

Figure 3.2 The categorization model and generic types of SCs. $\quad 58$

Figure 3.3 The categorization model and generic types of DCs. 61

Figure 3.4 The procedure and result of the systematic literature search. 63

Figure 4.1 Set-theoretic framework. 102

Figure 5.1 The conceptual model of this study. 136

Figure 5.2 The interaction effect of CQ and PA on IEI. 139

Figure 5.3 The interaction effect of CQ and SN on IEI. 142 

CHAPTER 1

Introduction 


\subsection{Introduction}

One and half billion downloads! TikTok surpassed Facebook only two years after its launch in 2017 (Chapple, 2019) and continues to be one among the most popular apps in the world. TikTok is an app that people use to create, watch, and share short lip-sync, comedy, and talent videos, usually in 15 seconds. Powered by artificial intelligence technologies, TikTok learns about users' habits and personalities and feeds them with the most interesting content. The more users use the app, the more they engaged. As of July 2018, it was reported that users spend an average of 52 minutes a day on TikTok (Mediakix, 2019). It is not surprising that Mark Zuckerberg, the founder of the Facebook empire, felt the threat of this video sharing app (Newton, 2019).

ByteDance, the parent company of TikTok, is emerging as one of the most successful Chinese internet technology company in the world. Established in March 2012 in Beijing, ByteDance hit a valuation of 75 billion USD as of November 2018. It is considered as the most valuable unicorns in the world (Reuters, 2018). Similar to TikTok, apps of ByteDance use artificial intelligence engines to attract users and increase user stickiness. For example, Toutiao, a news aggregator created by ByteDance, has 120 million daily active users as of September 2017 (He, 2017). With a huge user base, ByteDance obtains its revenue mainly from advertising. For the first half of 2018, ByteDance generated more than 7 billion USD in revenue.

ByteDance starts international expanding early in its life. ByteDance had its first global investment in an Indian news app Dailyhut in 2016, only three years after its establishment (Osawa \& Zhang, 2019). In early 2017, ByteDance bought a U.S. video-sharing app Filpagram (Osawa \& Zhang, 2019). In November 2017, ByteDance acquired Musical.ly, a video-sharing app with more than 200 million users worldwide (Fannin, 2019). By now, ByteDance operates over 20 apps in China and abroad and created a significant following around the world in the early stage of its international expansion. Currently, ByteDance has over 800 million daily active users and more than one billion registered users worldwide (Lahiri, 2019). TikTok, as the most popular ByteDance app abroad, enjoys phenomenal popularity in the world, especially in India. Within the 1.5 billion downloads, the India market contributed about 45 per cent, and the U.S. market contributed about 6 per cent (Chapple, 2019). 
It is of particular interest in how young technology companies from China can go early and rapid internationalization and achieve high international performance. Extant international business studies indicate that internationalization is challenging, especially for young firms. Newly established firms usually suffer from liabilities of newness (Freeman, Carroll, \& Hannan, 1983) and adolescence (Bruderl \& Schussler, 1990). That is young firms are more likely to fail than old ones. Furthermore, when they expand into international markets, they suffer from liabilities of foreignness (Zaheer, 1995) and outsidership (Johanson \& Vahlne, 2009). That is firms face uncertainties, risks, and costs when they come from outside of the local market. Challenges become fierce when taking account of the institutional uncertainties (Puffer, McCarthy, \& Boisot, 2010) and environmental uncertainties (Parnell, Lester, Long, \& Köseoglu, 2012) in transition economies like China.

Scholars argue that young entrepreneurial firms overcome these challenges by leveraging unique capabilities and strengths (Knight \& Cavusgil, 2004). A capability is "a learned and stable pattern of collective activity" (Zollo \& Winter, 2002 , p. 340) at the level of the firm. By definition, capabilities are usually virtual and intangible (Lin \& Tang, 2009). Such capabilities help firms to address the challenges of early internationalization. Young firms employ capabilities to develop unique products for international markets, and adapt to the dynamic international environment under conditions of resource deficiency to create competitive advantages (Cavusgil \& Knight, 2015). This allows them to achieve superior international performance.

However, the large and fragmented literature on capabilities is ambiguous about the way that capabilities are conceptualized. Such ambiguity calls for categorisation and a review on the literature on capabilities (Reuber, Dimitratos, \& Kuivalainen, 2017). Also, the literature tends to stress the independent and linear influence from specific capabilities on international performance. However, we argue that young entrepreneurial firms need a configuration of capabilities to compete in international markets. Therefore, the overarching research questions are: a) What capabilities do young entrepreneurial firms need; and b) how do these firms configure capabilities to achieve high international performance?

This dissertation examines the capabilities of early internationalizing firms (EIFs) need to succeed in international markets. Besides, it analyses how technology- 
based EIFs use the configuration of capabilities to achieve high international performance.

This dissertation includes four studies, two conceptual studies (one content analysis study and one systematic literature review), and two empirical studies. First, a content analysis is conducted on the research of EIFs in the context of China. This study takes stock of the topics in the extant Chinese EIFs studies. It provides suggestions for the future research agenda. Second, the systematic literature review discusses and categorizes capabilities that influence international performance. This study provides a foundation for the empirical studies that follow.

Third, our first empirical study explores the capability configuration for international performance in Chinese technology-based EIFs. The second empirical study examined the influence of personal-level capabilities on students' intention to conduct international entrepreneurial activities. Results from the conceptual and empirical studies offer insights into what the role of different types of capabilities have played in achieving international performance. Also, our findings shed light on how firms configure capability bundles to perform well in international markets. The findings contribute to a better understanding of capabilities and international performance in EIFs.

This introduction provides a brief overview of the theoretical foundation in research on capabilities and the EIFs (Section 1.2), leading to the formulation of the research problem and the main research question of this dissertation. Followed is the research approach this dissertation followed in conducting these four studies (Section 1.2.2). The last part comes with the outline of four studies in this dissertation (Section 1.3).

\subsection{Theoretical foundation and research questions}

\subsubsection{Early internationalizing firms}

The emergence of EIFs (Rialp, Rialp, \& Knight, 2005, p. 148), such as ByteDance, is attracting scholars' research interests (for reviews, see BaierFuentes, Hormiga, Miravitlles, \& Blanco-Mesa, 2019; Romanello \& Chiarvesio, 2019). EIFs are firms that "begin international activities soon after their establishment" (Romanello \& Chiarvesio, 2019, p. 4). Scholars focus on other 
similar types of firms that share the same thesis of "international at inception" with EIFs (Rialp et al., 2005, p. 148). For example, international new ventures (Khavul, Perez-Nordtvedt, \& Wood, 2010; Oviatt \& McDougall, 1994b), born global firms (Knight \& Cavusgil, 2004; Zhou, Wu, \& Luo, 2007), and global startups (Chin, Liu, \& Yang, 2016; Oviatt \& McDougall, 1995).

Research on EIFs is becoming an integral part of the growing international entrepreneurship literature (IE; McDougall, 1989; Oviatt \& McDougall, 1994a). IE research emerged at the intersection of international business and entrepreneurship research (McDougall \& Oviatt, 2000). It discusses "the discovery, enactment, evaluation, and exploitation of opportunities-across national borders - to create future goods and services." (Oviatt \& McDougall, 2005 , p. 540). IE research contributes to a better understanding of internationalization by exploring the formation, behaviours, and impacts of EIFs (McDougall, Shane, \& Oviatt, 1994). These studies complement to traditional internationalization theories by focusing on the entrepreneurs and their social network to explain the formation and behaviours of EIFs (McDougall et al., 1994). Therefore, IE research contributes to traditional internationalization theories such as internationalization process theory (Johanson \& Vahlne, 1977).

\subsubsection{CBP and EIFs' international performance}

What factors drive the outcomes (performance) of EIFs is a significant topic of discussion among the several key research topics in IE research (Keupp \& Gassmann, 2009). In research on EIFs' performance, the capability-based perspective (CBP; Teece, Pisano, \& Shuen, 1997a) is a well-established theoretical lens (Al-Aali \& Teece, 2014; Knight \& Cavusgil, 2004; Weerawardena, Mort, Liesch, \& Knight, 2007). The CBP holds that a firm's heterogeneity in conducting functional-directed behaviours (capabilities) can drive performance differences (Teece, 2007; Teece et al., 1997a). We adopt the definition of capability as "a learned and stable pattern of collective activity" (Zollo \& Winter, 2002, p. 340) at the level of the firm in this thesis work.

Two important classes of capabilities have been addressed in the literature: substantive capabilities and dynamic capabilities. The notion of substantive capabilities involves the performance of administrative, operational, and governance-related functions that allow firms to accomplish tasks in higher quality and with lower cost (Teece, 2014). Prior IE research shows that 
substantive capabilities, such as international marketing capability contribute to the firm's early entry into international markets (Weerawardena, Mort, \& Liesch, 2017).

The central notion of dynamic capabilities is to sense the change in the environment, formulate a response to the change, then take actions to implement the response (Teece, 2014). Dynamic capabilities contribute to firm performance by configuring the resources and substantive capabilities to address and shape rapidly changing business environments. For instance, dynamic capabilities such as adaptive capability and information acquiring capability play a positive mediating role in linking firm resources and Chinese entrepreneurial firms' international performance (Lu, Zhou, Bruton, \& Li, 2010).

The CBP can be used to explain EIFs' international performance for the following reasons. First, the tenet of the $\mathrm{CBP}$ - pursuing sustainable competitive advantage (Teece, 2007; Teece et al., 1997a) - is in line with the primary goal of EIFs. Scholars maintain that the ultimate goal in EIFs is "to derive significant competitive advantage from the use of resources and the sale of outputs in multiple countries" (Oviatt \& McDougall, 1994b, p. 31). Meanwhile, the notion of the CBP explains where a firm's sustainable competitive advantage come from and how a firm can sustain it (Teece, Pisano, \& Shuen, 1997b). Therefore, the CBP explains how do EIFs achieve sustainable competitive advantage and lead to their performance in the end.

Second, the core thesis of CBP literature could explain the origin and future performance of EIFs. The CBP emphasises opportunity identification in dynamic environments (Al-Aali \& Teece, 2014), which conforms the definition that EIFs originate from cross-border opportunities discovery and exploitation (McDougall \& Oviatt, 2003). CBP researchers advocate the framework of "sensing-seizing-transforming" of identifying and exploiting opportunities (Teece, 2007). Meanwhile, EIF literature suggests that cross-border opportunities identification and exploitation defines EIFs (Keupp \& Gassmann, 2009; McDougall \& Oviatt, 2003). Furthermore, higher dynamic capabilities help EIFs discover and seize more international opportunities, therefore contribute to EIFs' international performance (e.g., internationalization scope and extent). Consequently, the CBP could explain EIFs' opportunity exploitation and further performance in international markets. 


\subsubsection{Alternative perspectives and EIFs' international performance}

Some alternative perspectives can explain the international performance of EIFs. For example, the resource-based view, the knowledge-based perspective, and strategic orientations (for reviews, see Keupp \& Gassmann, 2009; Romanello \& Chiarvesio, 2019). The resource-based view stresses the importance of owning unique resources or assets on achieving high performance in EIFs. However, resources have been criticized as either ambiguous or confusing to obtain (Kraaijenbrink, Spender, \& Groen, 2009). The knowledge-based view holds that knowledge is the primary resource underlying competitive advantage (Felin \& Hesterly, 2007). Strategic orientation literature suggests that some firms' unique proclivities distinguish themselves from rival firms in creating values and competitive advantage (Boso, Story, \& Cadogan, 2013). Such proclivity includes the tendency to accept innovativeness, risk-taking, proactiveness, competitive aggressiveness and autonomy (Lumpkin \& Dess, 1996). However, these resources, knowledge, or orientation are firms' assets instead of actions. We argue what matters for EIFs' international performance are actions EIFs take (capabilities) to create value in international markets.

For this $\mathrm{PhD}$ research, the CBP is appropriate for the explanation of EIFs' international performance. We argue such appropriateness from the following three aspects. First, we argue that it is the entrepreneurial actions that determine new venture's ability to compete with their rivals instead of the resources owned by them. Zahra (2005) states that "entrepreneurial firms are defined by their actions, not by the types of resources they have or control" (p. 21). Further, the definition of EIFs "is concerned with value added, not assets owned" (Oviatt \& McDougall, 1994a, p. 49). Moreover, capabilities represent organizational behaviours that make differences to the outcome by definition, while resources or knowledge or orientations need to be translated into actions before having a direct influence on value creation.

Second, capabilities are virtual and intangible by definition; such feature appeals to the requirements of low resource-demanding in EIFs' development and international expansion (Cavusgil \& Knight, 2015). Al-Aali and Teece (2014) argue that the unique resources cannot contribute to sustainable competitive advantage in a rapidly changing environment. Accordingly, they suggest the capabilities that can renew firms' resource base are the real source of the longrun competitive advantage. Further, the changing international environment asks for additional resources that contribute to the competitive advantage (Oviatt \& 
McDougall, 1994a, p. 51). Accordingly, to sustain long-lived competitive advantage, EIFs need to get additional resources, therefore, bear more costs and risks. Obtaining intangible capabilities instead of tangible resources, therefore, reduce the costs, risks, and other challenges of internationalization.

Third, we argue that the activities to orchestrate and update resources (capabilities) are more valuable than resources per se. The capability represents the management of the resources of the firm, and the management of resources may be more important than the resources themselves (Al-Aali \& Teece, 2014). From Al-Aali and Teece (2014) point of view, "strong dynamic capabilities coupled with good strategy work together to generate and sustain superior enterprise performance in fast-moving global environments (p. 95)". Additionally, the criteria for resources - valuable, rare, inimitable, and nonsubstitutable (Barney, 1991), have been criticized as unable to explain sustainable competitive advantage (Kraaijenbrink et al., 2009). These criteria are regarded as the basic conditions of competitive advantage, instead of sufficient ones. Furthermore, scholars argue that it is not the possession of resources, but the deployment of these contribute to the competitive advantage (Kraaijenbrink et al., 2009). Consequently, "studying internationalization using a capabilities lens is appropriate and complementary to other resource-based explanations" (Sapienza, Autio, George, \& Zahra, 2006, p. 915). To summarize, it is appropriate to study EIFs' international performance from the CBP.

\subsubsection{Capability bundles and capability configurations}

Although dynamic capabilities are thought to improve firm performance and performance-related factors, researchers like Eisenhardt and Martin (2000) argue that effective dynamic capabilities are an essential part of but not sufficient enough for competitive advantage. Peteraf, Di Stefano, and Verona (2013) argue that the locus of competitive advantage lies in the form of dynamic bundle of capabilities, rather than in simple or stable routines (substantive capabilities) or complex routines (dynamic capabilities) in isolation.

Dynamic bundle of capabilities consists of both substantive capabilities, and dynamic capabilities are based on dynamic capability frame (Teece et al., 1997a). At the initial stage, firms have a certain bundle of capabilities. It then becomes necessary to develop or transform capabilities to achieve long-term growth (Lichtenstein \& Brush, 2001). Besides, dynamic capabilities are not supposed to 
generate value alone (Teece, 2012), which calls for the combination with substantive capabilities (Caloghirou, Kastelli, \& Tsakanikas, 2004; Lee, Lee, \& Pennings, 2001; Peteraf et al., 2013). In dynamic environments, firms need dynamic capabilities to change the way how they use their resources to address the turbulence (Eisenhardt \& Martin, 2000). In the context of IE, dynamic capabilities influence the venture's long-term economic return and global competitive advantage via capability upgrading (Luo, 2000).

Here, we argue that configurations of bundles, rather than configurations of singular capabilities or singular bundles, are associated with superior international performance. This argument is based on management systems theory (Mintzberg, 1980), which argues that firms need a set of functions and, hence, capabilities (Teece, 2014) to operate. More specifically, the idea of capability complementarity (Ennen \& Richter, 2010) or capability configurations (Sjödin, Parida, \& Kohtamäki, 2016) illustrates that capabilities contribute more strongly to firm performance when they operate in combinations (Su, Peng, Shen, \& Xiao, 2013). Karna, Richter, and Riesenkampff (2016) summarize this argument as follows: "a regrouping of different types of capabilities into more meaningful, conceptually distinct categories would provide a better theoretical understanding of the role of capabilities as performance drivers" (p. 1169).

\section{$1.3 \quad$ Research approach}

\subsubsection{Conceptual research approach}

A content analysis on the research of Chinese EIFs. Chapter 2 focuses on reviewing research on the EIFs in China, with the aims of consolidating the current knowledge, identifying research gaps, and providing suggestions for future study. The rapid increase of young Chinese firms goes into international markets, and the proliferation of research on this topic calls for consolidation and synthesis on the knowledge of this topic. Existing review studies mainly focus on the development of general IE, not specifically on the context of China (for a review, see Jones, Coviello, \& Tang, 2011; Keupp \& Gassmann, 2009; Kiss, Danis, \& Cavusgil, 2012; Romanello \& Chiarvesio, 2019). 
This chapter reviews the scholarship on Chinese EIFs and offers insights into the specific areas in critical need of further development. It used a coherent framework to organize the findings that result from the content analysis. This study generalized three top-level thematic categories of inquiry that focus on the antecedents, elements and outcomes of Chinese EIFs. Additionally, it sorts out four research streams among these thematic categories and identified several inconsistencies and understudied research questions. This study provides recommendations for a future study aimed at developing a more integrated research agenda on Chinese EIFs for scholars. Therefore, Chapter 2 answers the following questions:

Question 2.1: What research topics have been studied in the literature of EIFs in China?

Question 2.2: What are the future research topics to gain a better understanding of EIFs in China?

A systematic literature review on capabilities for EIFs' international performance. Chapter 3 addresses the importance and the categorization of capabilities in the IE literature. Researchers are seeking guidance on the types of capabilities for the international performance of EIFs (Reuber et al., 2017). Here, we offer this called-for guidance by providing a novel capability categorization model that reviews and classifies the state-of-the-art in the capability-based literature on EIFs. Research on dynamic capabilities has focused on international market observation, evaluation, and resource reconfiguration. Research on substantive capabilities has focused on international market operations. Research gaps exist on the interactions between capabilities, and on the domestic marketoriented capabilities. We propose a research agenda for capabilities-based IE research. Accordingly, Chapter $\mathbf{3}$ shed lights on the following questions:

Question 3.1: How can we categorize the capabilities that are related to international performance?

Question 3.2: Which capabilities are studied in research on the international performance of EIFs? 


\subsubsection{Empirical research approach}

An empirical study on capability configuration and EIFs' international performance. The rising of the early international expansion of Chinese firms attracts research interest (Kiss et al., 2012; Naudé \& Rossouw, 2010). Chinese EIFs face internationalization challenges, for example, an imperfect market economy, insufficient financial support, and unstable policies (Zhu, Wittmann, $\&$ Peng, 2012). Previous research points out that capabilities are the important factors facilitate Chinese EIFs to tackle these challenges and achieve high performance (De Clercq, Sapienza, \& Zhou, 2014; Zhou et al., 2007). Chapter 4 explores the configuration of capability bundles that lead to the high international performance of Chinese EIFs. This chapter contributes to the IE literature by applying the set-theoretic perspective on the relationship between capabilities and international performance of technology-based EIFs. This perspective addresses conjunction, equifinality, and asymmetry in the capabilityperformance relationship, which goes beyond the linear logic that was the foundation of much of prior research (Douglas, Shepherd, \& Prentice, 2020; Misangyi et al., 2017). We contribute to the strategic management literature by extending and supporting the notion of the dynamic bundle, which combines dynamic and substantive capabilities of the same kind. To support our contribution, we use a fuzzy-set Qualitative Comparative Analysis on 88 technology-based EIFs. Our results show configurations of dynamic bundles that are associated with high international performance. Chapter 4 provides insights into answering the following question:

Question 4: What are the capability bundles of Chinese technologybased EIFs use to achieve high international performance?

An empirical study of individual capabilities and international entrepreneurial intention. Chapter 5 investigates the influence of personal-level capabilities on students' intention to start international entrepreneurship. The literature on capabilities indicates that the individual level capabilities are the foundation of organizational level capabilities (Nelson \& Winter, 1982). The scarce study focuses on the relationship between individual-level capabilities and entrepreneurial intention. This chapter intends to contribute to entrepreneurship education by identifying and fostering potential international entrepreneurs. We apply the theory of planned behaviour (Ajzen, 1985, 1991) with the integration of capabilities of global mindset and cultural intelligence as predicts of students' 
international entrepreneurial intention. A sample of 84 students is collected and analyzed with OLS regression and moderation analysis. This chapter answers the following question:

Question 5: How are students' personal capabilities related to their intention of international entrepreneurship?

\section{$1.4 \quad$ Outline of this dissertation}

The central thesis of this dissertation focuses on the configuration of capabilities and EIFs' international performance. Chapter 4 reports an empirical study to explore this relationship. Since classification is the foundation of configurations, this dissertation presented a study on the classification of firm-level capabilities in Chapter 3. Furthermore, Chapter 2 reports a systematic literature review to shed lights on the elements that have been studied in EIFs as the fundamental components of configurations. In the end, this dissertation conducted a study on entrepreneurship education on the drivers of international entrepreneurship intention (Chapter 5), regarding the importance of international entrepreneurship to economic development. As a synopsis of this dissertation, Figure 1.1 provides the outline of this dissertation and logical connections among chapters.

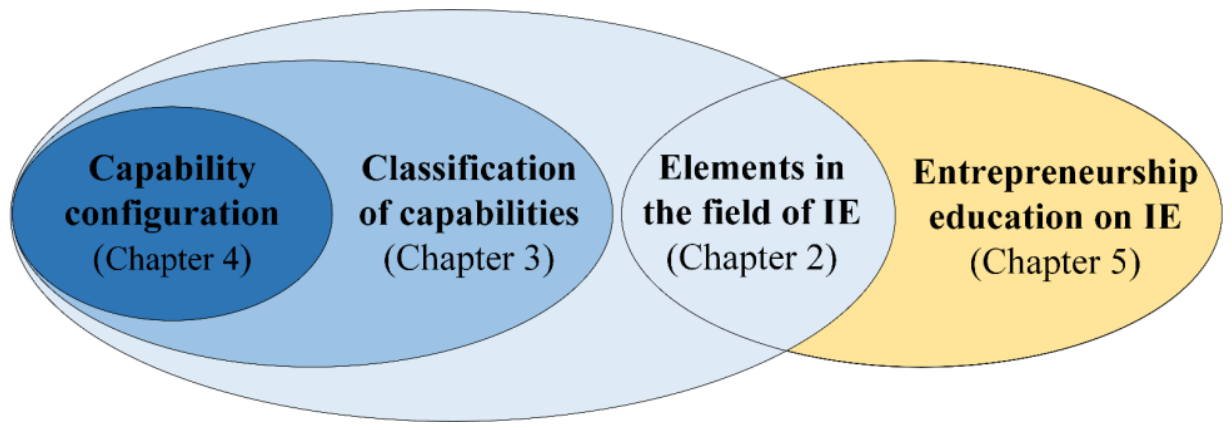

Figure 1.1. Dissertation outline. 


\section{References}

Ajzen, I. (1985). From intentions to actions: A theory of planned behavior. In Action control (pp. 11-39): Springer.

Ajzen, I. (1991). The theory of planned behavior. Organizational Behavior and Human Decision Processes, 50(2), 179-211. doi:10.1016/0749-5978(91)90020-t

Al-Aali, A., \& Teece, D. J. (2014). International Entrepreneurship and the Theory of the (Long-Lived) International Firm: A Capabilities Perspective. Entrepreneurship Theory and Practice, 38(1), 95-116. doi:10.1111/etap.12077

Baier-Fuentes, H., Hormiga, E., Miravitlles, P., \& Blanco-Mesa, F. (2019). International entrepreneurship: a critical review of the research field. European Journal of International Management, 13(3), 381-412. doi:10.1504/Ejim.2019.099427

Barney, J. (1991). Firm Resources and Sustained Competitive Advantage. Journal of Management, 17(1), 99-120. doi:10.1177/014920639101700108

Boso, N., Story, V. M., \& Cadogan, J. W. (2013). Entrepreneurial orientation, market orientation, network ties, and performance: Study of entrepreneurial firms in a developing economy. Journal of Business Venturing, 28(6), 708-727. doi:10.1016/j.jbusvent.2013.04.001

Bruderl, J., \& Schussler, R. (1990). Organizational Mortality - the Liabilities of Newness and Adolescence. Administrative Science Quarterly, 35(3), 530-547. doi:10.2307/2393316

Caloghirou, Y., Kastelli, I., \& Tsakanikas, A. (2004). Internal capabilities and external knowledge sources: complements or substitutes for innovative performance? Technovation, 24(1), 29-39. doi:10.1016/S0166-4972(02)00051-2

Cavusgil, S. T., \& Knight, G. (2015). The born global firm: An entrepreneurial and capabilities perspective on early and rapid internationalization. Journal of International Business Studies, 46(1), 3-16. doi:10.1057/jibs.2014.62

Chapple, C. (2019, November 14). TikTok clocks 1.5 billion downloads on the App Store and Google Play. Retrieved from https://sensortower.com/blog/tiktokdownloads-1-5-billion

Chin, T., Liu, R. H., \& Yang, X. M. (2016). 'Reverse internationalization' in Chinese firms: A study of how global startup OEMs seek to compete domestically. Asia Pacific Business Review, 22(2), 201-219. doi:10.1080/13602381.2015.1055087

De Clercq, D., Sapienza, H. J., \& Zhou, L. (2014). Entrepreneurial strategic posture and learning effort in international ventures: The moderating roles of operational flexibilities. International Business Review, 23(5), 981-992. doi:10.1016/j.ibusrev.2014.03.001

Douglas, E. J., Shepherd, D. A., \& Prentice, C. (2020). Using fuzzy-set qualitative comparative analysis for a finer-grained understanding of entrepreneurship. 
Journal of Business $\quad$ Venturing, 35(1), 105970. doi:10.1016/j.jbusvent.2019.105970

Eisenhardt, K. M., \& Martin, J. A. (2000). Dynamic capabilities: What are they? Strategic Management Journal, 21(10-11), 1105-1121. doi:https://doi.org/10.1002/1097-0266(200010/11)21:10/11<1105::AIDSMJ133>3.0.CO;2-E

Ennen, E., \& Richter, A. (2010). The whole is more than the sum of its parts - or is it? A review of the empirical literature on complementarities in organizations. Journal of $\quad$ Management, 36(1), 207-233. doi:https://doi.org/10.1177/0149206309350083

Fannin, R. (2019). The strategy behind TikTok's global rise. Harvard Business Review, 2019(December 8).

Felin, T., \& Hesterly, W. S. (2007). The knowledge-based view, nested heterogeneity, and new value creation: Philosophical considerations on the locus of knowledge. Academy of Management Review, 32(1), 195-218. doi:10.5465/amr.2007.23464020

Freeman, J., Carroll, G. R., \& Hannan, M. T. (1983). The liability of newness: Age dependence in organizational death rates. American Sociological Review, 692710 .

He, W. (2017, September 6). Jinri Toutiao looks to BRICS nations. Retrieved from http://www.chinadaily.com.cn/bizchina/2017-09/06/content_31619329.htm

Johanson, J., \& Vahlne, J.-E. (1977). The internationalization process of the firm-A model of knowledge development and increasing foreign market commitments. Journal of International Business Studies, 8(1), 23-32.

Johanson, J., \& Vahlne, J. E. (2009). The Uppsala internationalization process model revisited: From liability of foreignness to liability of outsidership. Journal of International Business Studies, 40(9), 1411-1431. doi:10.1057/jibs.2009.24

Jones, M. V., Coviello, N., \& Tang, Y. K. (2011). International Entrepreneurship research (1989-2009): A domain ontology and thematic analysis. Journal of Business Venturing, 26(6), 632-659. doi:10.1016/j.jbusvent.2011.04.001

Karna, A., Richter, A., \& Riesenkampff, E. (2016). Revisiting the role of the environment in the capabilities-financial performance relationship: A metaanalysis. Strategic Management Journal, 37(6), 1154-1173. doi:10.1002/smj.2379

Keupp, M. M., \& Gassmann, O. (2009). The past and the future of international entrepreneurship: A review and suggestions for developing the field. Journal of Management, 35(3), 600-633.

Khavul, S., Perez-Nordtvedt, L., \& Wood, E. (2010). Organizational entrainment and international new ventures from emerging markets. Journal of Business Venturing, 25(1), 104-119. doi:10.1016/j.jbusvent.2009.01.008 
Kiss, A. N., Danis, W. M., \& Cavusgil, S. T. (2012). International entrepreneurship research in emerging economies: A critical review and research agenda. Journal of Business Venturing, 27(2), 266-290. doi:10.1016/j.jbusvent.2011.09.004

Knight, G. A., \& Cavusgil, S. T. (2004). Innovation, organizational capabilities, and the born-global firm. Journal of International Business Studies, 35(2), 124-141. doi:10.1057/palgrave.jibs.8400071

Kraaijenbrink, J., Spender, J. C., \& Groen, A. J. (2009). The Resource-Based View: A Review and Assessment of Its Critiques. Journal of Management, 36(1), 349372. doi:10.1177/0149206309350775

Lahiri, T. (2019, March 4). Facebook finally has a serious - and very fun - Chinese rival. Retrieved from https://qz.com/1564270/bytedance-video-app-tiktok-rival-tofacebook-reached-1-billion-downloads/

Lee, C., Lee, K., \& Pennings, J. M. (2001). Internal capabilities, external networks, and performance: A study on technology-based ventures. Strategic Management Journal, 22(6-7), 615-640. doi:10.1002/smj.181

Lichtenstein, B. M. B., \& Brush, C. G. (2001). How do "resource bundles" develop and change in new ventures? A dynamic model and longitudinal exploration. Entrepreneurship Theory and Practice, 25(3), 37-58. doi:https://doi.org/10.1177/104225870102500303

Lin, G. T. R., \& Tang, J. Y. H. (2009). Appraising Intangible Assets from the Viewpoint of Value Drivers. Journal of Business Ethics, 88(4), 679-689. doi:10.1007/s10551-008-9974-y

Lu, Y., Zhou, L. X., Bruton, G., \& Li, W. W. (2010). Capabilities as a mediator linking resources and the international performance of entrepreneurial firms in an emerging economy. Journal of International Business Studies, 41(3), 419-436. doi:10.1057/jibs.2009.73

Lumpkin, G. T., \& Dess, G. G. (1996). Clarifying the entrepreneurial orientation construct and linking it to performance. Academy of Management Review, 21(1), 135-172. doi:10.2307/258632

Luo, Y. D. (2000). Dynamic capabilities in international expansion. Journal of World Business, 35(4), 355-378. doi:10.1016/S1090-9516(00)00043-2

Mcdougall, P. P. (1989). International versus domestic entrepreneurship - New venture strategic behavior and industry structure. Journal of Business Venturing, 4(6), 387-400. doi:10.1016/0883-9026(89)90009-8

McDougall, P. P., \& Oviatt, B. M. (2000). International entrepreneurship: The intersection of two research paths. Academy of Management Journal, 43(5), 902-906. doi:10.2307/1556418

McDougall, P. P., \& Oviatt, B. M. (2003a). Some fundamental issues in international entrepreneurship. Entrepreneurship Theory and Practice, 18, 1-27. doi:10.1.1.210.861 
McDougall, P. P., \& Oviatt, B. M. (2003b). Some fundamental issues in international entrepreneurship. Entrepreneurship Theory and Practice, 18, 27.

Mcdougall, P. P., Shane, S., \& Oviatt, B. M. (1994). Explaining the formation of international new ventures - The limits of theories from international-business research. Journal of Business Venturing, 9(6), 469-487. doi:https://doi.org/10.1016/0883-9026(94)90017-5

Mediakix. (2019). 13 TikTok statistics marketers need to know: TikTok demographics \& key data. Retrieved from https://mediakix.com/blog/top-tik-tok-statisticsdemographics/

Mintzberg, H. (1980). Structure in 5's - A synthesis of the research on organization design. Management Science, 26(3), 322-341. doi:10.1287/mnsc.26.3.322

Misangyi, V. F., Greckhamer, T., Furnari, S., Fiss, P. C., Crilly, D., \& Aguilera, R. (2017). Embracing Causal Complexity: The Emergence of a NeoConfigurational Perspective. Journal of Management, 43(1), 255-282. doi:10.1177/0149206316679252

Naudé, W., \& Rossouw, S. (2010). Early international entrepreneurship in China: Extent and determinants. Journal of International Entrepreneurship, 8(1), 87-111. doi:10.1007/s10843-010-0049-7

Nelson, R. R., \& Winter, S. G. (1982). The Schumpeterian tradeoff revisited. American economic review, 72(1), 114-132. doi:https://www.jstor.org/stable/1808579

Newton, C. (2019, October 1). Read the full transcript of Mark Zuckerberg's leaked internal Facebook meetings: Highlights from two hours of leaked audio from recent Q\&A sessions with Facebook's CEO. Retrieved from https://www.theverge.com/2019/10/1/20892354/mark-zuckerberg-fulltranscript-leaked-facebook-meetings

Osawa, J., \& Zhang, Y. (2019, June 25). How ByteDance founder is building a global tech giant from China. Retrieved from https://www.theinformation.com/articles/how-bytedance-founder-is-buildinga-global-tech-giant-from-china

Oviatt, B. M., \& Mcdougall, P. P. (1994a). Toward a Theory of International New Ventures. Journal of International Business Studies, 25(1), 45-64. doi:10.1057/palgrave.jibs.8490193

Oviatt, B. M., \& McDougall, P. P. (1994b). Toward a theory of international new ventures. Journal of International Business Studies, 45-64.

Oviatt, B. M., \& McDougall, P. P. (1995). Global start-ups: Entrepreneurs on a worldwide stage. Academy of Management Perspectives, 9(2), 30-43. doi:https://doi.org/10.5465/ame.1995.9506273269

Oviatt, B. M., \& McDougall, P. P. (2005). Defining international entrepreneurship and modeling the speed of internationalization. Entrepreneurship Theory and Practice, 29(5), 537-553. doi:10.1111/j.1540-6520.2005.00097.x 
Parnell, J. A., Lester, D. L., Long, Z., \& Köseoglu, M. A. (2012). How environmental uncertainty affects the link between business strategy and performance in SMEs. Management Decision, 50(4), 546-568. doi:10.1108/00251741211220129

Peteraf, M., Di Stefano, G., \& Verona, G. (2013). The Elephant in the Room of Dynamic Capabilities: Bringing Two Diverging Conversations Together. Strategic Management Journal, 34(12), 1389-1410. doi:10.1002/smj.2078

Puffer, S. M., McCarthy, D. J., \& Boisot, M. (2010). Entrepreneurship in Russia and China: The Impact of Formal Institutional Voids. Entrepreneurship Theory and Practice, 34(3), 441-467. doi:10.1111/j.1540-6520.2009.00353.x

Reuber, A. R., Dimitratos, P., \& Kuivalainen, O. (2017). Beyond categorization: New directions for theory development about entrepreneurial internationalization. Journal of International Business Studies, 48(4), 411-422. doi:10.1057/s41267017-0070-3

Reuters. (2018). China's Bytedance seeks to raise $\$ 3$ bln at up to $\$ 75$ bln valuation sources. Retrieved from https://www.reuters.com/article/bytedancefundraising/chinas-bytedance-seeks-to-raise-3-bln-at-up-to-75-bln-valuationsources-idUSL5N1UZ0C3

Rialp, A., Rialp, J., \& Knight, G. A. (2005). The phenomenon of early internationalizing firms: What do we know after a decade (1993-2003) of scientific inquiry? International Business $\quad$ Review, 14(2), 147-166. doi:10.1016/j.ibusrev.2004.04.006

Romanello, R., \& Chiarvesio, M. (2019). Early internationalizing firms: 2004-2018. Journal of International Entrepreneurship, 17(2), 172-219. doi:10.1007/s10843018-0241-8

Sapienza, H. J., Autio, E., George, G., \& Zahra, S. A. (2006). A capabilities perspective on the effects of early internationalization on firm survival and growth. Academy of Management Review, 31(4), 914-933. doi:10.5465/Amr.2006.22527465

Sjodin, D. R., Parida, V., \& Kohtamaki, M. (2016). Capability configurations for advanced service offerings in manufacturing firms: Using fuzzy set qualitative comparative analysis. Journal of Business Research, 69(11), 5330-5335. doi:10.1016/j.jbusres.2016.04.133

Su, Z. F., Peng, J. S., Shen, H., \& Xiao, T. (2013). Technological Capability, Marketing Capability, and Firm Performance in Turbulent Conditions. Management and Organization Review, 9(1), 115-137. doi:10.1111/j.1740-8784.2011.00280.x

Teece, D. J. (2007). Explicating dynamic capabilities: The nature and microfoundations of (sustainable) enterprise performance. Strategic Management Journal, 28(13), 1319-1350. doi:10.1002/smj.640

Teece, D. J. (2012). Dynamic Capabilities: Routines versus Entrepreneurial Action. Journal of Management Studies, 49(8), 1395-1401. doi:10.1111/j.14676486.2012.01080.x 
Teece, D. J. (2014). The foundations of enterprise performance: Dynamic and ordinary capabilities in an (economic) theory of firms. Academy of Management Perspectives, 28(4), 328-352. doi:10.5465/amp.2013.0116

Teece, D. J., Pisano, G., \& Shuen, A. (1997a). Dynamic capabilities and strategic management. Strategic Management Journal, 18(7), 509-533. doi:10.1002/(Sici)1097-0266(199708)18:7<509::Aid-Smj882>3.0.Co;2-Z

Teece, D. J., Pisano, G., \& Shuen, A. (1997b). Dynamic capabilities and strategic management. Strategic Management Journal, 509-533.

Weerawardena, J., Mort, G. S., \& Liesch, P. W. (2017). Capabilities development and deployment activities in born global B-to-B firms for early entry into international markets. Industrial Marketing Management.

Weerawardena, J., Mort, G. S., Liesch, P. W., \& Knight, G. (2007). Conceptualizing accelerated internationalization in the born global firm: A dynamic capabilities perspective. Journal of World Business, 42(3), 294-306. doi:10.1016/j.jwb.2007.04.004

Zaheer, S. (1995). Overcoming the Liability of Foreignness. Academy of Management Journal, 38(2), 341-363. doi:10.2307/256683

Zahra, S. A. (2005). A theory of international new ventures: a decade of research. Journal of International Business Studies, 36(1), 20. doi:10.1057/palgrave.jibs.8400118

Zhou, L. X., Wu, W. P., \& Luo, X. M. (2007). Internationalization and the performance of born-global SMEs: The mediating role of social networks. Journal of International Business $\quad$ Studies, 38(4), 673-690. doi:10.1057/palgrave.jibs.8400282

Zhu, Y. M., Wittmann, X., \& Peng, M. W. (2012). Institution-based barriers to innovation in SMEs in China. Asia Pacific Journal of Management, 29(4), 1131-1142. doi:10.1007/s10490-011-9263-7

Zollo, M., \& Winter, S. G. (2002). Deliberate learning and the evolution of dynamic capabilities. Organization Science, 13(3), 339-351. 


\section{CHAPTER 2 \\ The Development of Research on Chinese Early Internationalizing Firms: A Review and Content Analysis}

An early version of the chapter has been presented as:

Jie, S., Harms, R., \& Groen, A. J. (2019). Trends and foundations in Chinese technology-based international new ventures. Paper presented at the 27th Annual High Technology Small Firms Conference (HTSF), Enschede, Netherlands.

This chapter is prepared for submission to International Business Review. 


\section{$2.1 \quad$ Introduction}

The rise of Chinese firms go into international competition at their early stages is burgeoning. On the one hand, many big Chinese companies develop with internationalization in their infancy. For example, the startups of Alibaba and Baidu arouse from their founders' abroad experience (Barboza, 2006; Wang, 2014), and the survival and expansion of Huawei rely on its first overseas contract (Chang et al., 2009). On the other hand, young Chinese firms show high international market engagement and present outstanding international performance. For instance, young Chinese firms like DJI, Xiaomi, and UBTECH are currently the world's leading players in the market of consumer and commercial drones, smartphones, and education with robotics (Kantar, 2019).

Those Chinese firms that "begin international activities soon after their establishment" (Romanello \& Chiarvesio, 2019, p. 4) are called Chinese early internationalizing firms (CEIFs) by scholars. The investigation on CEIFs subordinates to the broader research field of international entrepreneurship (IE; McDougall, 1989; Oviatt \& McDougall, 1994). The literature on CEIFs covers research on several types of Chinese firms, such as international new ventures (Khavul, Perez-Nordtvedt, \& Wood, 2010; Oviatt \& McDougall, 1994), born global firms (Knight \& Cavusgil, 2004; Zhou, Wu, \& Luo, 2007), global startups (Chin, Liu, \& Yang, 2016; Oviatt \& McDougall, 1995), and early internationalizing firms (EIFs; Rialp, Rialp, \& Knight, 2005; Tsukanova \& Zhang, 2019). Since these types of firms share a similar definition of “international at inception” with EIFs (Rialp et al., 2005, p. 148).

The proliferation of existing literature on CEIFs contribute to the understanding of IE phenomenon in China; however, there lacks a consolidation and synthesis on the knowledge of CEIFs. Existing literature on CEIFs investigates the emergent (e.g., Yamakawa, Khavul, Peng, \& Deeds, 2013), development (e.g., Zou \& Ghauri, 2010), and performance of EIFs (e.g., Zhou \& Wu, 2014) in the context of China. However, no study focuses on integrating the development of CEIFs into a framework to the best of our knowledge. Previous IE review studies focus either on the development of general IE research (e.g., Dzikowski, 2018; Jones, Coviello, \& Tang, 2011; Keupp \& Gassmann, 2009; Romanello \& Chiarvesio, 2019) or on the context of emerging economies (Kiss, Danis, \& Cavusgil, 2012). Furthermore, considering the growing prominence of Chinese 
companies in the global economics (Buckley et al., 2007; UNCTAD, 2019), and the important role entrepreneurship play in driving their international expansion (Liu, Li, \& Xue, 2011; Zhang, Ma, \& Wang, 2012), we need more understanding of the existing development of CEIFs.

Therefore, it is imperative to synthesize the conceptual and empirical findings toward a more integrated understanding of CEIFs. The goals of this review work are as follows: (1) to systematically evaluate the theoretical and empirical development of the literature on CEIFs; (2) to map out the state-of-the-art of CEIFs literature set to identify the inconsistencies and overlooked research gaps; and (3) to provide suggestions for future research aiming at developing a more integrated research agenda on CEIFs.

The tasks are important for several reasons: Firstly, a timely synthesis and consolidation of existing knowledge contributes to the basis of theory extension and building in the research field of IE (Deng, 2012). The ongoing US-China trade war spotlights the internationalization of Chinese firms (Qiu \& Wei, 2019) - both mature and new ventures. This influential global event provides us with a seasonable opportunity to review and consolidate the existing development of CEIFs, so as to consolidate the theoretical extension of IE research in the context of China. Secondly, the identification of key elements in CEIFs provides a framework for future research and encourages the cross-comparison of research findings (Barney \& Zhang, 2009; Child, 2009). The consolidation on the findings of the emergent, development, and performance of CEIFs provide opportunities to compare the research in the context of China with the general IE research, therefore, identify an opportunity for under-studied topics (Kiss et al., 2012). Also, comprehensive knowledge of CEIFs makes it possible to make a comparison between China and other economies (Kiss et al., 2012).

Thirdly, the component factors of CEIFs identified and the research model proposed in this study can be adopted and further developed in the context of other emerging economies (Mellahi \& Sminia, 2009). This review work provides concluded experiences of CEIFs and provides suggestions for future firms that want to go to international competition or firms in other economies with similar context. Previous international business and IE literature show that expanding into international markets is challenging (Tang, 2011), as firms encounter challenges such as the liability of foreignness (Zaheer, 1995), newness (Morse, Fowler, \& Lawrence, 2007), and outsidership (Johanson \& Vahlne, 2009). It becomes even more exaggerated under such context of transition economies as 
China (Puffer, McCarthy, \& Boisot, 2010). Therefore, a systematic literature review on the existing CEIFs literature contributes to the understanding of how CEIFs overcome these barriers. Such experience is beneficial for other emerging countries in transition. Moreover, expand the boundary of the IE literature (Deng, 2012).

The structure of this paper is as follows. First, we present a description of the methodology used for approaching our systematic literature review and analysis. Then, we report a coherent framework to organize the findings result out from our content analysis. Furthermore, we outline the discussion on the findings of research on CEIFs and implications, including future research directions. Finally, the conclusions and limitations come in the end.

\section{$2.2 \quad$ Methodology}

\subsubsection{Method of literature search}

We apply a systematic way (Tranfield, Denyer, \& Smart, 2003; Wang \& Chugh, 2014) to determine which articles are relevant to this review. We start from defining the research domain of IE by adopting McDougall and Oviatt (2000) definition: "International entrepreneurship is a combination of innovative, proactive, and risk-seeking behaviour that crosses national borders and is intended to create value in organizations" (p. 903). We use this definition because it can capture both the type of empirical IE research that is focused on analysing small new ventures, as well as IE articles that make contributions irrespective of firm size or age and conceptual IE articles (Keupp \& Gassmann, 2009). Several types of ventures are studied within the boundary of this definition. For example, international new ventures (Coviello, 2006), born globals (Knight \& Cavusgil, 2004), and early internationalizing firms (Rialp et al., 2005). After that, we define the research context setting of potential studies to be the mainland of China (excluding Hong Kong, Macao, and Taiwan). With the context boundary, we included studies that address an empirical issue by using the data based on managers or firms from the mainland of China (Yang \& $\mathrm{Li}, 2008$ ), or a theoretical issue by focusing the discussion on the mainland of China. 
We limited our review to peer-review journal articles, omitting books, book chapters, and other non-refereed publications. Because journal articles can be considered validated knowledge and are likely to have the highest impact on the field (Podsakoff, MacKenzie, Bachrach, \& Podsakoff, 2005). Although this approach does not cover non-journal publications, we do feel that it provides an accurate and representative picture of the area on which IE scholars have chosen to focus their research attention and resources. We focus the main source of our journal publication on the electronic databases of Scopus, Science Direct, and Web of Science. Although the China National Knowledge Infrastructure (CNKI) is another important source of studies on CEIFs, we worry about the searching and coding reliabilities, therefore, leave for future research.

As to the search term, we use the following terms: ("Chin*" OR "emerging" OR "developing") AND ("international entrepreneur*" OR "international new venture" OR "INV" OR "born global" OR "BG" OR "exporting SME" OR "early international*" OR "international startup" OR "early internationalizing firm" OR micro-multination OR "global startup") in the field of title and abstract. We also check for alternative spellings in the above search term; for example, we alternatively use "born-global", "internationalisation", and "start-up". We identified a total number of 439 articles (after duplication delectation) under the subject area of "Business, Management, and Accounting" at this searching stage. By applying the exclusion criteria align with the conceptual boundaries defined above, we gleaned a number of $\mathbf{4 2}$ papers into the final analytical process. Figure 2.1 presents our systematic literature searching process and results in each stage. A shortlist of these articles is in Appendix. 


\section{Setting the research objectives:}

- Identify research status of international entrepreneurship in the context of China;

- Seek to advance the research niche of early internationalization in the context of China.

Defining the conceptual boundaries:

- Defining international entrepreneurship

- Defining research context settings

Setting the inclusion criteria

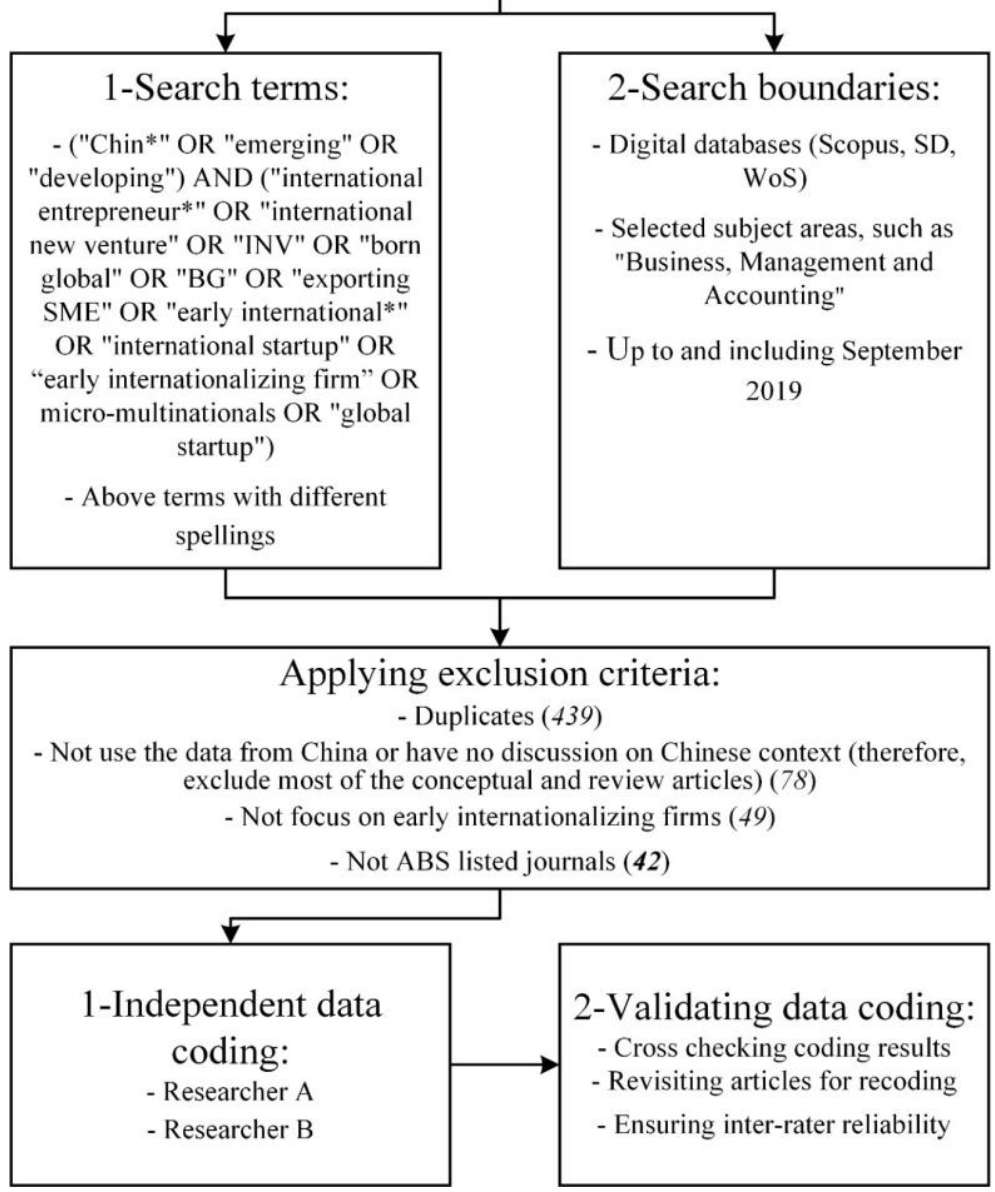

Figure 2.1. The procedure and result of the systematic literature search. 


\subsubsection{Procedure of analysis}

To identify what is the research status of CEIFs studies, we apply the framework from Keupp and Gassmann (2009, p. 605) to categorise the topics distilled from these articles. The framework from Keupp and Gassmann (2009, p. 605) summarises the most frequently treated topics in 172 IE articles published in top journals from 1994 to 2007. There are three top-level categories (antecedents, elements, and outcomes), 12 sub-level categories, and 40 meta-themes derived from the cluster analysis on the research topics in the framework (Keupp \& Gassmann, 2009).

We follow a deductive approach to decide the belonging of each variable. Specifically, first, we list all independent variables and dependent variables analysed in the quantitative studies. Second, we analyse the meaning of each variable and assign it to the meta-theme with the best match in Keupp and Gassmann (2009, p. 605) framework. Third, we cross-check our categorization among scholars to finalise the distribution of all analysed variables and report it in Figure 2.2.

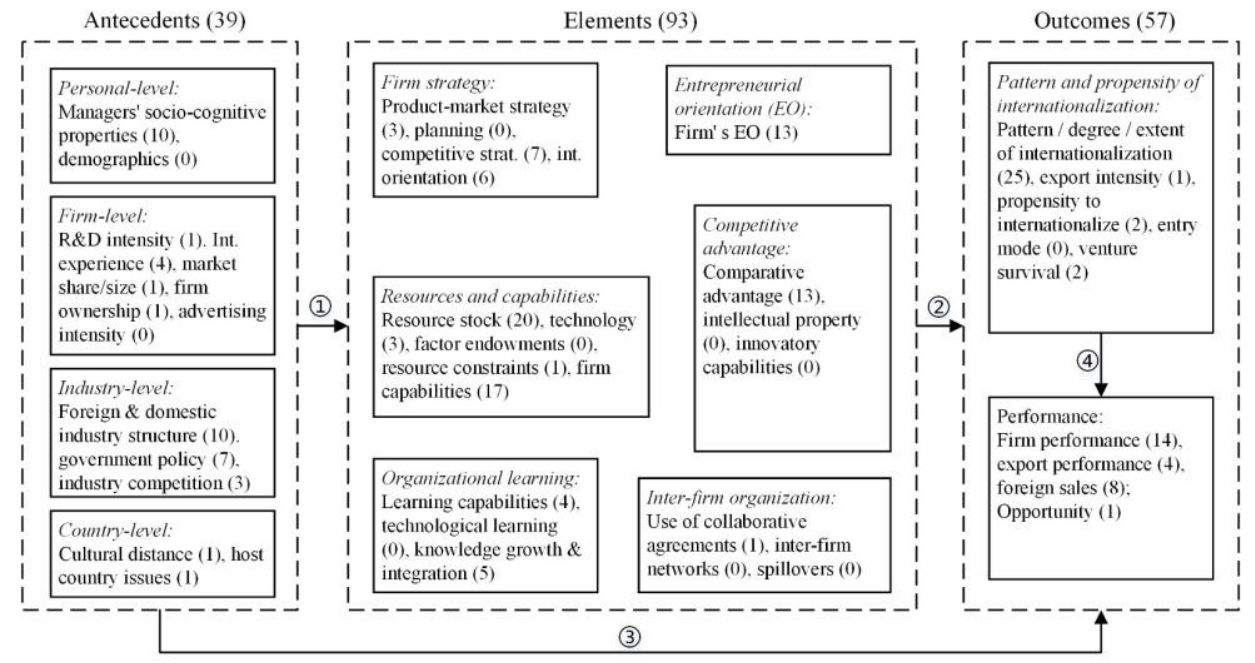

Figure 2.2. Organizing framework of the literature and counts of the most frequent topics treated therein.

Notes: Counts are not mutually exclusive. Arrows indicate the causal connections between elements that studies have analysed. 


\section{$2.3 \quad$ Findings}

In this section, we offer an account of the state of current knowledge concerning early internationalizing firms in China. We report the number of meta-themes analysed by these articles as an overview of these studies' research topic. Besides, we present the research focus by clustering their research themes as revelled in the articles reviewed.

The main findings from our content analysis are presented in Figure 2.2. Figure 2.2 provides a graphical representation of how CEIFs articles' subject matters that are distributed over the top-level categories, sub-level categories, and metathemes based on the framework from Keupp and Gassmann (2009). As stated in 2.2 , we count once when an independent variable or a dependent variable appears. We find that studies on CEIFs have mostly analysed the elements $(\mathrm{n}=93)$, followed by the outcomes $(n=57)$ and the antecedents $(n=39)$.

Among the antecedents in the CEIFs studies, the industry-level factors $(\mathrm{n}=20)$ received the most attention. Especially the foreign \& domestic industry at the industry level $(\mathrm{n}=10)$, followed by government policy $(\mathrm{n}=7)$ and industry competition $(\mathrm{n}=3)$. Meanwhile, the personal-level themes received less attention and all studies focused on managers' socio-cognitive properties $(\mathrm{n}=$ 10). Followed is factors on the firm level, with four on international experience, and one for each on R\&D intensity, market share/size, and firm ownership. Finally, the country-level factors received the least attention with only one on the cultural distance.

When we examined the theme analysed in the Elements category, we discovered that a clear dominantly of the articles focused on the resources and capabilities $(n=41)$. In this sub-level category, the resource stock $(n=20)$ and firm capabilities $(n=17)$ received the most frequent research, with few studies focus on the technology $(n=3)$ and resource constraints $(n=1)$. Furthermore, a relative smaller group $(n=16)$ of themes belongs to the firm strategy sub-category, with larger number of meta-themes on competitive strategy $(n=7)$, international orientation $(n=6)$ and product-market strategy $(n=3)$. Moreover, a smaller number of meta-themes come from firm's entrepreneurial orientation $(n=13)$, the competitive advantage $(n=13)$, and organizational learning $(n=9)$. Only one element belongs to the inter-firm organization sub-category. 
While in the outcomes analysed in these CEIFs studies, two sub-categories of pattern and propensity of internationalization $(n=30)$ and the performance $(n=$ 27) received similar attention. In the sub-category of pattern and propensity of internationalization, dominant themes belong to the pattern or the degree or the extent of internationalization $(\mathrm{n}=25)$. The rest meta-themes belong to the propensity to internationalize $(n=2)$, venture survival $(n=2)$ and export intensity $(\mathrm{n}=1)$. Additionally, in the performance sub-category, a large group of variables come from the firm performance $(n=14)$, the smaller size of variables come from foreign sales $(n=8)$. The rest variables come from the export performance $(n=4)$ and the newly identified opportunity $(n=1)$.

We further investigated the results of Figure 2.2 by extracting the research question from all articles (includes qualitative studies) and analysing what elements and connections among the elements they studied. These results are detailed in Table 2.1, and the causal connections are shown in Figure 2.2. Figure 2.2 indicates three causal connections (or topic clusters) between the three toplevel categories (arrows 1-3). Also, with one connection insides the outcomes (arrow 4), which emerges as one important research stream in the reviewed CEIFs articles.

Table 2.1 indicates that the most considerable part of existing studies on CEIFs is still "outcome-driven." As more than $76 \%$ of all the causal links (arrow 2 and 3 ) extracted from the literature strive to explain the scope, extent, patterns, and performance implications of internationalization. From Table 2.1, the research focus of CEIFs studies has avoided the early stage of identifying the "success factors" contribute to the success of a firm's internationalization (Keupp \& Gassmann, 2009, p. 608). Instead, their focuses are dominantly on the firm-level elements, e.g., firm strategy or resources and capabilities. These factors are linked to the process of internationalization. Such progress on exploring the "why question" of IE (Keupp \& Gassmann, 2009, p. 608), which helps to increase the external theoretical legitimization of IE studies. We analysis each topic cluster in detail on their findings below. 
Table 2.1 Research focus of all reviewed articles.

\begin{tabular}{|c|c|c|}
\hline Research focus & Amount & Art. No. \\
\hline Analyses from antecedents to elements (Arrow (1)) & 2 & \\
\hline $\begin{array}{l}\text { 1. Relationship between managers' socio-cognitive } \\
\text { properties and firm resources or strategies. }\end{array}$ & 2 & $14 ; 30$ \\
\hline Analyses from elements to outcomes (Arrow (2)) & 24 & \\
\hline $\begin{array}{l}\text { 1. Influence of firm resources and capabilities on } \\
\text { internationalization and/or international } \\
\text { performance. }\end{array}$ & 11 & $\begin{array}{l}4 ; 7 ; 13 ; \\
17 ; 24 ; 26 ; \\
28 ; 30 ; 37 \\
38 ; 41\end{array}$ \\
\hline $\begin{array}{l}\text { 2. Influence of firm strategy on survival, } \\
\text { profitability, export intensity, or performance in } \\
\text { foreign markets. }\end{array}$ & 5 & $\begin{array}{l}6 ; 16 ; 22 ; \\
35 ; 40\end{array}$ \\
\hline $\begin{array}{l}\text { 3. Consequences of entrepreneurial orientation on } \\
\text { internationalization and/or performance. }\end{array}$ & 4 & $\begin{array}{l}1 ; 9 ; 19 ; \\
20\end{array}$ \\
\hline $\begin{array}{l}\text { 4. Influence of cooperation activities (alliances, } \\
\text { joint ventures, networking) on internationalization. }\end{array}$ & 2 & $11 ; 12$ \\
\hline $\begin{array}{l}\text { 5. Impact of approaches to organizational learning } \\
\text { on new venture performance. }\end{array}$ & 1 & 10 \\
\hline $\begin{array}{l}\text { 6. Impact of competitive advantage on subsequent } \\
\text { internationalization. }\end{array}$ & 1 & 39 \\
\hline Analysis from antecedents to outcomes (Arrow (3)) & 10 & \\
\hline $\begin{array}{l}\text { 1. Impact of socio-cognitive or demographic } \\
\text { properties of managers or owners on the propensity } \\
\text { to internationalize. }\end{array}$ & 5 & $\begin{array}{l}3 ; 8 ; 18 ; \\
27 ; 32\end{array}$ \\
\hline $\begin{array}{l}\text { 2. Industry-level factors that determine the } \\
\text { propensity to internationalize and/or export } \\
\text { performance. }\end{array}$ & 4 & $\begin{array}{l}29 ; 33 ; 35 ; \\
42\end{array}$ \\
\hline $\begin{array}{l}\text { 3. Country-level factors that determine the } \\
\text { propensity to internationalize and/or export } \\
\text { performance. }\end{array}$ & 1 & 34 \\
\hline $\begin{array}{l}\text { Analyses on implications of internationalization } \\
\text { (Arrow (4)) }\end{array}$ & 9 & \\
\hline 1. Implications from early internationalization. & 9 & $\begin{array}{l}2 ; 5 ; 13 ; \\
15 ; 21 ; 23 ; \\
25 ; 31 ; 36\end{array}$ \\
\hline
\end{tabular}

Notes: Counts exceed the number of literature as some studies focus on complex interacting causalities (e.g., mediation), we count the main causal links with a dependent variable. 


\subsubsection{Analyses from antecedents to elements}

Although the size of factors in the antecedents category is relatively large, studies that focus on examining the relationship between antecedents and elements are at scarcity. Some studies set these antecedent factors as non-important independent variables or moderating variables. For example, Zhou (2007) investigated the moderating effects of cultural diversity on the entrepreneurial proclivity and found a marginal negative influence.

Articles in this cluster studied the influence from different level preconditions (antecedents) for the organizational elements. As shown in Table 2.1, the identified articles analysed relationships between managers' socio-cognitive properties and firms' resources or strategies. For example, articles show that founding team's experience contributes significantly to firms' strategic orientation and international commitment (Khavul, Prater, \& Swafford, 2012) and firms' international market knowledge (Bai, Johanson, \& Martín Martín, 2017).

\subsubsection{Analyses from elements to outcomes}

Articles in this cluster study the influence from different organizational factors on firm's internationalization and performance. In this cluster, firms' resources and capabilities have been studied the most frequently. Among articles that focus on resources, knowledge and guanxi are the two dominantly studied resources. Various kinds of knowledge have been studied. For example, technological knowledge (Yamakawa et al., 2013), international market knowledge (Bai et al., 2017), and opportunity knowledge (Bai, Johanson, \& Martin, 2019). Although there are different opinions on the influence of knowledge and network resources (Tsukanova \& Zhang, 2019), the main conclusion from these studies acknowledge the positive effects from resources and capabilities on the internationalization and firm performance (Bai et al., 2017; Bai et al., 2019; Yamakawa et al., 2013).

Another critical resource - guanxi, a trust-based informal personal network (Zhou et al., 2007), has been studied intensively in the context of China specifically. Scholars usually treat guanxi as one important source of information that contributes to firm performance (Zhang, Gao, Wheeler, \& Kwon, 2016; Zhang \& Hartley, 2018; Zhou et al., 2007) or international opportunities (Ellis, 2011). For example, guanxi is used by ventures to build products that satisfy 
foreign customers' demand to keep their loyalty on the product (Zhang \& Hartley, 2018). However, the use of guanxi is not always beneficial for firms' development. For example, in the later internationalization stage of Chinese BGs, guanxi is found to burden their management team and decelerate the internationalization (Vissak \& Zhang, 2016) due to the "reciprocal nature" of guanxi (p. 286).

For studies focus on the capabilities, various capabilities have been studied. For example, international entrepreneurship capability (Zhang, Tansuhaj, \& McCullough, 2009), information acquisition capability and adaptive capability (Lu, Zhou, Bruton, \& Li, 2010), international networking capability (Bai, Holmström Lind, \& Johanson, 2016), and learning capabilities (De Clercq, Zhou, $\& \mathrm{Wu}, 2016)$. These capabilities help ventures to build entrepreneurial strategies (Zhang et al., 2009), or acquiring necessary network knowledge (Bai et al., 2016), or addressing market turbulence (De Clercq et al., 2016), all contribute to the rapid internationalization or firm performance in the end.

Studies that focus on the outcome implications from various firm strategies include strategies such as customer support investment (Khavul, Peterson, Mullens, \& Rasheed, 2010), technology leverage and license (Tan \& Mathews, 2015), niche and strategic alliance strategies (Qian, Li, \& Qian, 2018), and the combination of exploitation and exploration (Lin \& Si, 2019). For example, investing in customer support was found to promote Chinese international new ventures' learning and performance (Khavul, Peterson, et al., 2010), while the ambidexterity strategy improves BGs' international performance (Lin \& Si, 2019). Furthermore, utilizing strategies such as technology leveraging and license agreements (Tan \& Mathews, 2015) and niche and strategic alliance strategies (Qian et al., 2018) helps ventures to go early internationalization.

Studies focus on entrepreneurial orientations' consequences on internationalization and/or performance usually address their influences on learning activities (De Clercq, Sapienza, \& Zhou, 2014; De Clercq \& Zhou, 2014; Zhou, 2007), and capability upgrading (Zhou, Barnes, \& Lu, 2010). Aggressive learning activities and capability upgrading help Chinese venture to attenuate the liability of foreignness or newness, consequently achieve rapid internationalization and performance. For instance, entrepreneurial orientation (proclivity or posture) contributes to the learning of foreign market knowledge (Zhou, 2007), enhances the international learning efforts (De Clercq et al., 2014; De Clercq \& Zhou, 2014), and leads to the rapid internationalization or 
performance improvements in eventually. Besides, ventures' entrepreneurial behaviours contribute to the performance advantage through capability upgrading (Zhou et al., 2010).

Studies that analyze the influence of cooperation activities on internationalization usually regard the networking activities as ventures' important source of information. For example, entrepreneurs' social ties have been identified as a type of information exchange that contribute to the identity of international opportunities (Ellis, 2011). Additionally, ventures' networking behaviours contribute to the accumulation of network resources, which in turn, enable them to go for rapid internationalization (Tang, 2011).

Remaining studies in this cluster investigated how Chinese new ventures conduct their organizational learning to achieve early internationalization (Zou \& Ghauri, 2010) and how specific competitive advantage influence subsequent internationalization (Hull, Tang, Tang, \& Yang, 2019). Findings indicate that during the internationalization process, these new ventures establish internal mechanisms and inter-organizational networks to facilitate knowledge learning and leveraging and to diminish negative influences brought by cultural uncertainties (Zou \& Ghauri, 2010). Moreover, in the knowledge learning process, ventures' international learning orientation transfer the accumulated knowledge into the degree of international engagement and commitment (Zou \& Ghauri, 2010). Additionally, being born global at the first beginning is an advantage for continuous internationalization (Hull et al., 2019). Hull et al. (2019) find that being born-global from the beginning are less likely to quit exporting. However, pursuing innovative ventures while going global increases the odds of quitting (Hull et al., 2019).

\subsubsection{Analyses from antecedents to outcomes}

The third cluster includes studies that analyse how different level of factors influence the internationalization outcomes. In this cluster, scholars mainly focus on personal-level and industry-level factors. Studies that focus on the personallevel factors highlight the resources brought by the entrepreneurs/founder team. Such resources could be international experience (Ciravegna, Majano, \& Zhan, 2014), networks (Lin, Mercier-Suissa, \& Salloum, 2016), and knowledge and social capitals (Liu, 2017). When entrepreneurs/founder team in the venture have necessary resources, they are more likely go rapid internationalization (Lin et al., 
2016), have more export sales (Naudé \& Rossouw, 2010), and have a larger internationalization scope (Ciravegna et al., 2014). Otherwise, these ventures tend to develop via the approach of "bounded entrepreneurship", which means the combination of traditional gradual and the rapid pattern of internationalization (Liu, Xiao, \& Huang, 2008).

Studies that focus on the industry-level factors highlight influences from the government (Zhang, Gao, \& Cho, 2017; Zhang et al., 2016), and industry uncertainties (Jean, Kim, \& Cavusgil, 2020; Qian et al., 2018). Furthermore, these industrial conditions usually interact with organizational elements to influence firm performance. For example, government support facilitates building international entrepreneurial capability (Zhang et al., 2017) and interacts with firm strategy (Zhang et al., 2016) to improve firm performance. Meanwhile, the interactions between industry dynamism and firms' niche strategy (Qian et al., 2018) and between the digital platform risk and firms' entrepreneurial orientation (Jean et al., 2020) contribute the early and rapid internationalization.

Studies that focus on the country-level factors are at the minority. The only study in this cluster analyzed the influence of home market liberalization and host market openness on the profitability of Chinese international new ventures (Deng, Jean, \& Sinkovics, 2018). Their findings indicate that the faster these ventures expand to markets with higher openness than the home market (upward expansion) the more profit they get, and the faster these ventures expand to markets with lower openness than the home market (downward expansion) the less profit they get. Also, the home market liberalization enhances the positive influence of upward expansion and the negative influence of downward expansion on profitability.

\subsubsection{Analyses on implications of internationalization}

Studies in this cluster focus on the (performance) implications of (early) internationalization and emerged as one crucial research stream in the literature set of CEIFs. Scholar Aiqi Wu and her colleagues contribute significantly to this research topic, e.g., De Clercq et al. (2016); Wu and Voss (2015); Wu and Zhou (2018); Zhou and $\mathrm{Wu}$ (2014); Zhou, Wu, and Barnes (2012). Studies investigated the benefits brought by the early and rapid internationalization in Chinese new ventures. These benefits include financial performance, such as profitability 
(Zhou et al., 2007) and sales growth (Clegg, Lin, Voss, Yen, \& Shih, 2016; Wood et al., 2011; Wu \& Voss, 2015; Zhou \& Wu, 2014; Zhou et al., 2012), and strategic performance, such as continuous internationalization (Deng, Jean, \& Sinkovics, 2017) and geographic diversity (Wu \& Zhou, 2018).

However, these benefits are not come by nature but need a transfer mechanism. Studied mechanisms include social networks (Zhou et al., 2007), marketing capabilities (Zhou et al., 2012), absorptive capacity (Wu \& Voss, 2015), and strategic flexibility (Wu \& Zhou, 2018). For example, the early international market entry contributes to international growth by enhancing ventures' marketing capabilities (Zhou et al., 2012), and when the venture's absorptive capacity is stronger, the association gets stronger (Wu \& Voss, 2015).

\subsection{Discussion and implications for future research}

We start by discussing the development of the CEIFs article set. After that, we discuss the findings in our content analysis. Finally, we report some inconsistencies and research gaps identified for future research agenda.

The literature set on CEIFs is rapidly growing and has covered many important research areas. However, the research on CEIFs is still in its infancy. Both the body of the relevant literature in total and the journal publication per year are small in size. The final identified paper from our careful systematic search is 42 papers, while there are 280 publications in general IE field over the year 20042018 (Romanello \& Chiarvesio, 2019). The emergent of research on CEIFs is relatively late. The first journal paper on the topic of CEIFs appeared in the year of 2007 (see Appendix), while the IE research starts from 1994 (Zahra, 2005). However, considering China joined the WTO at the end of 2001 and the private firms start to have the independent export rights from 2003, the development of CEIFs is notable (Naudé \& Rossouw, 2010) and the growth of the research body is rapid.

As to the results of our content analysis, much of the existing study on CEIFs addressed the why question of IE phenomenon in China. That is elements such as firm strategy, resources and capabilities, and organizational learning, all of which enable Chinese entrepreneurial firms to expand into international markets early on in an entrepreneurial manner. As highlighted by Keupp and Gassmann (2009), the enrich in the research focus on elements contributes to the increase of "external theoretical legitimization" (p. 608) of IE research. Also, much of the 
existing literature seeks to understand whether the internationalization behaviour of CEIFs conforms to the predictions of IE theory in advanced economies. As many of the variables come from previous IE study examined in advanced markets, and unique factors (e.g. guanxi) analysed in the literature are scarce. However, the testing of theories from western countries in the context of China also provides an opportunity to expand the theory boundary of IE (Alon, Anderson, Munim, \& Ho, 2018).

As to the results of thematic analysis, we identified four main research streams which have materialized with the literature set on CEIFs. They are: (1) analyse how antecedents influence the organizational elements; (2) analyse how the elements influence the internationalization outcomes; (3) analyse how the antecedents influence the outcomes; (4) analyse the implications of early internationalization. The second research stream mainly explains how Chinese new ventures can go early and rapid internationalization and achieve performance from different perspectives, such as resources or capabilities. Research stream 3 mainly investigates how the attributes of entrepreneurs and industries influence the internationalization process and subsequent performance. Research stream 4 analysed the implications of early internationalization, most of which are positive. There is a scarce in the research stream of analysing how antecedents influence the organizational elements.

Research in the first stream answers questions such as (a) why do some Chinese entrepreneurial firms want to expand their business internationally, and (b) where are the sources of these drivers/elements. Unfortunately, the existing CEIFs literature failed to reveal the distinctiveness of IE phenomenon in China. That is, the existing study in the first stream has limited contribution to understanding why CEIFs choose to go early internationalization, why they choose specific internationalization strategies, and the market locations of their foreign entry in the internationalization process. Only one exception explored why do new ventures from emerging countries (including China) want to expand to advanced markets in their early times (Yamakawa et al., 2013). Their findings indicate that these new ventures want to expand their business into advanced markets because they want to improve domestic reputation, to create wealth from existing knowledge stocks and to benefit from acquiring new knowledge (Yamakawa et al., 2013). Unique factors such as institutional factors or government policies are usually treated as control variables and did not get 
sufficient attention or deeper exploitation. Several promising areas emerge after drawing linages among the revealed meta-themes and research streams.

\subsubsection{Research gaps for studies focus on the Antecedents}

Existing literature set on CEIFs pays few attentions on the country-level metathemes, and in particular, it overlooked the geopolitical factors in the antecedent category. In light of the current geopolitical situations, we call for scholars' attention on the influence of geopolitical issues on the development of CEIFs and in a broader sense. The prior international business study underlines the "borderless world" as one fundamental antecedent for the early internationalization of new ventures (Johnson, 2004, p. 142). The decreasing trade regulations globally fertilises the exploration of international transaction opportunities in new ventures (Cavusgil \& Knight, 2015), and the cross-border opportunity explorations facilitate the emergence of EIFs (Knight \& Cavusgil, 2004; Oviatt \& McDougall, 1994). However, the current tense geopolitical situations increase uncertainties and challenges for doing international business in the global environment.

One recent and influential example of the tense geopolitical situation is the bilateral tariff war between the US and China (Liu \& Woo, 2018) starts from January 2018. The trade war between these two most prominent countries in terms of GDP in the Pacific Rim has caused a broad impact on the global economy ( $\mathrm{Li}, \mathrm{He}, \& \mathrm{Lin}, 2018)$. For example, the tension between the US and China are believed to cause a slowdown in the economic development and uncertainties of international investment in emerging markets (Pangestu, 2019; Semin, Kostyaev, Truba, Ponkratov, \& Gagarina, 2019). Furthermore, specifically for China, the ongoing US-China trade war is expected to cause challenges for Chinese enterprises (Witt, 2019). For example, Chinese enterprises will have difficulties in obtaining advanced technologies and knowledge, they may encounter difficulties in integrating foreign suppliers in the supply chain, and they will encounter troubles regards the liability of foreignness. As one specific and typical example of these challenges, Huawei, as the world's second-largest telecommunication manufactory from China, has to quit the US market due to the increasingly tense relationship between the US and China ( $\mathrm{Su}$, 2018). Also, the export ban from the US government has threatened Huawei's supply chain (Fung, 2019). 
Therefore, the current US-China trade war provides opportunities to explore influences from additional country-level antecedents, e.g. the geopolitical issues, on the formation and development of CEIFs. Questions such as how the relationship between the US and China influence the firm strategy and decision making in the CEIFs, and how will such uncertainties influence the pattern of internationalization and their performance are remaining understudied, and we call for future studies.

\subsubsection{Research gaps for studies focus on the Elements}

Even though the most significant amount of current literature set on CEIFs focuses on the elements and covers many topics (see Figure 2.2), there are still many vital meta-themes understudied in the elements category. Here we list what we think are the most critical four topics and provide suggestions for future research accordingly. These understudied topics are conflicting relations between resource and capabilities, performance implications from separately analysed capabilities, the missing analysis of intellectual property influences, and the overlook of explaining learning processes.

First, we identified that in the existing literature set on CEIFs, the causal relationships between firm resources and capabilities are inconsistent. Some studies argue and hypothesize that capabilities are the antecedents of resources, that is capabilities lead to the obtaining and accumulating of the firm resource base. For example, both Tang (2011) and Bai et al. (2016) argue that firms' international networking capabilities contribute to the obtaining of resources (network resources and international business knowledge). Their empirical findings provide supports to their arguments and show the positive mediating influences of resources between the capability and the outcomes. While on the other hand, the study argues and hypothesizes that the firm resource base is the foundation of firm capabilities, that is resources are the base for a firm to build capabilities. For example, Lu et al. (2010) argue and verify that the institutional capital and managerial ties are the bases of firms' information acquisition capability and adaptive capability for international performance.

We argue that such conflict association roots in the confusion of substantive and dynamic capability. The substantive and dynamic capability are the primary two types of firms' capability, which is defined as "a learned and stable pattern of collective activity" (Zollo \& Winter, 2002, p. 340) at the level of the firm. 
Substantive capabilities (Zahra, Sapienza, \& Davidsson, 2006) are capabilities that utilize available resources to accomplish tasks to create value, at least for the short term, for the organization (Teece, 2014; Winter, 2003; Zahra et al., 2006). Meanwhile, dynamic capabilities are "the capacity of an organization to purposefully create, extend, or modify its resource base" (Helfat, 2007, p. 1). Simply put it, substantive capabilities are the activities to utilize resources while dynamic capabilities are those to modify, change and add resources. The existing Chines IE literature failed to make a clear distinction between these two terms, and the interchangeable use of the substantive and dynamic capabilities causes the conflicting association between resources and capabilities. Therefore, we argue for the necessity of categorizing substantive and dynamic capabilities. In addition, we call for carefully use of these two terms in the future study applying the capability-based perspective in research on CEIFs or broader research field.

Second, we found that all empirical studies that analyse the capabilityperformance relations in the literature treat different capabilities as if they work independently from another. Also, all these studies adopt the linear logic and hypothesize that the higher the capability level, the better the performance. For instance, the analytical methods used in studies from Tang (2011), Wu and Voss (2015), and Bai et al. (2016) support our argument. However, we argue that the perspective to analyse capabilities independently is problematic theoretically, and the dominating use of linear analytic logic is problematic methodologically. Firstly, the perspective to analyse capabilities independently neglects the complex interactions between capabilities (Black \& Boal, 1994; Colbert, 2004; Sjödin, Parida, \& Kohtamäki, 2016). The prior study holds that firm capabilities configure resources in interacting forms of compensatory, enhancing, and suppressing/destroying (Black \& Boal, 1994). Studies that ignore interactions between capabilities may fail to uncover complex interdependencies that exist among capabilities, leading to faulty theory and mis-specified implications for practice. Furthermore, the linear analytic logic has limited explanatory power when the number of capabilities goes up to an amount (Mikalef \& Pateli, 2017). As the performance usually comes out with the coordination of its sub-unites and functions, it becomes problematic when the number of functions/capabilities involved outnumbers the maximum variables the model can handle.

As a suggestion to solve this problem, we recommend future study that investigates the capabilities-performance association adopts the set-theoretic perspective (Fainshmidt, Wenger, Pezeshkan, \& Mallon, 2019; Zadeh, 1965) and 
use a qualitative comparative analysis approach (Rihoux \& Ragin, 2009b). The set-theoretic perspective allows to model conjunction, equifinality, and asymmetry (Fiss, 2011). In so doing, we move beyond independent linear relationships to patterns of capabilities that together are characteristics of highperforming CEIFs. Meanwhile, the qualitative comparative analysis approach builds on fuzzy-set theory (Zadeh, 1965) and discovers causal patterns by examining the attributes of configurations that belong in the outcome set (Rihoux \& Ragin, 2009a). This approach allows us to analyse complex causality and to examine necessary and sufficient conditions. We argue that these patterns (configurations) are a more valid representation of the reality of capabilityperformance relationships. Having this more valid representation is relevant for future IE research that can further explore set-theoretic approaches to performance, and for practitioners who can base strategic decisions on the gap between the existing capability portfolio and what is desired.

Third, we want to draw scholars' attention on the understudied research topic of the relationship between the intellectual property and the internationalization process and outcome in CEIFs. It is surprising to find that no study focuses on intellectual property in CEIFs. As statistics show that Chinese firms are active in intellectual property applications and the number of patents registration in China has ranked the top one for 11 consecutive years (WIPO, 2019). One reason may be because not many articles in the existing literature set on CEIFs focus on hightech industrial settings. The samples investigated in the current literature are mostly manufacturing firms that do not conduct research and development activities to product patents; therefore, intellectual properties do not emerge as one crucial research topic.

Nonetheless, we believe that EIFs play some vital role in the vast number of patents in China. Although there are no direct references, we can get such an indication from secondary data sources. For example, statistically, Chinese SMEs contribute to $66 \%$ of the patents nationwide and $74 \%$ of the technological innovations (Zhu, Wittmann, \& Peng, 2012). Meanwhile, these SMEs are the largest export business entities and account for more than $60 \%$ of the import and export trade in China (NBSC, 2018). Theoretically, EIFs (as one specific type of SMEs) are considered to enter international niche markets with strategies such as "securing patent technology" (McDougall, 1989, p. 387).

In summary, we argue that intellectual property plays some crucial roles in the motivation of CEIFs' early and rapid internationalization, as well as their 
internationalization process and subsequent performance. The previous study shows that patents hold by entrepreneurial firms - as a representation of firms' innovation activities is positively related to their internationalization (Wang, Hsu, \& Fang, 2008). As suggestions for future studies, we call for studies on (1) whether and how the intellectual property assets motivate the early internationalization of CEIFs; (2) what are the relationships between the location of patent registration and EIFs' entry markets; (3) how the quantity of the patents influence the scope/speed/extent of EIFs' internationalization; and (4) how intellectual property rights protection in the home and host country influence the internationalization process/patterns.

Fourth, we want to highlight that the how question of the organizational learning in CEIFs is also insufficiently investigated in the current literature set on CEIFs. The current CEIFs research tends to investigate the outcome of learning (e.g., De Clercq et al., 2014; Zhou, 2007), rather than delve into how these outcomes are achieved, only with few exceptions (e.g., Zou \& Ghauri, 2010). However, examining the processes of learning is a critical concern in IE study (McDougall, Shane, \& Oviatt, 1994; Zahra, Ireland, \& Hitt, 2000). The exploration of the learning processes helps to understand why do some EIFs learn faster and more effective while others not. Which consequently contribute to the understanding of crucial questions in IE study, such as why the early and rapid internationalization is possible and the performance heterogeneity in EIFs.

As a future research agenda, we suggest future research to focus on the personallevel learning activities in CEIFs. Since previous research hold that the individuals are the primary learning entity in the firm (Dodgson, 1993) and the meta unit to transfer knowledge into organizations (Antonacopoulou, 2006). Related research questions are (1) How do entrepreneurs in EIFs learn in their domestic market, and how do they learn in their foreign markets? (2) When, where, and how do the organizational learning activities happen on the personal level? Furthermore, (3) How do entrepreneurs transfer knowledge from foreign markets into the domestic market or into their firms? We believe the solving of the above questions contribute to a better understanding of CEIFs' entrepreneurial internationalization processes. 


\subsection{Conclusion and limitation}

The early and rapidly internationalizing phenomenon in China has been relevant in the field of international entrepreneurship research. This systematic review confirms this view and discusses in-depth the role of antecedents, elements, and outcomes that indicate the state-of-the-art of CEIFs (see Figure 2.2). We compared the state-of-the-art with Keupp and Gassmann (2009) framework on general IE research by content analysis. We discovered several promising avenues for future research (see 2.4) that could lead to a more in-depth understanding of the IE phenomenon in China. Hence, our study contributes significantly to the literature of CEIFs and the field of general IE research.

We have several limitations. The first limitation of the paper relates to the limited number of articles reviewed. However, we would argue that positive aspects include clear criteria for the inclusion and exclusion of the articles in question (see 2.2.1). The second limitation relates to the scope of our research focus. We mainly focus on the research content of these studies; however, we did not consider methodological issues or theoretical approaches. Therefore, we are unable to compare the research settings and check the theoretical problems in the current literature set. Thirdly, we only included relevant studies published in international journals; however, did not involve those published in Chinese journals. The scope of our research setting may limit our understanding of the IE phenomenon in China, since some interesting research questions may only be studied by native Chinese scholars and published only in Chinese journals. Accordingly, future study is also suggested to address these limitations and include relevant good quality Chinese publications to have a broader and indepth understanding of research on CEIFs.

This review study pointed out five promising future research directions; they are (1) to investigate how geopolitical factors influence the development and outcomes of CEIFs; (2) to clarify and categorize different types of capabilities to show their influence on outcomes precisely; (3) to analyse the capabilityperformance relationship from a set-theoretical perspective; (4) to study influences from the intellectual property on CEIFs; (5) to focus on the personallevel learning activities in CEIFs. We encourage future studies to address the above limitations and follow the suggested research directions to have a deeper understanding of CEIFs. 


\section{References}

Alon, I., Anderson, J., Munim, Z. H., \& Ho, A. (2018). A review of the internationalization of Chinese enterprises. Asia Pacific Journal of Management, 35(3), 573-605. doi:10.1007/s10490-018-9597-5

Antonacopoulou, E. P. (2006). The relationship between individual and organizational learning: New evidence from managerial learning practices. Management learning, 37(4), 455-473. doi:10.1177/1350507606070220

Bai, W., Holmström Lind, C., \& Johanson, M. (2016). The performance of international returnee ventures: The role of networking capability and the usefulness of international business knowledge. Entrepreneurship and Regional Development, 28(9-10), 657-680. doi:10.1080/08985626.2016.1234003

Bai, W., Johanson, M., \& Martín Martín, O. (2017). Knowledge and internationalization of returnee entrepreneurial firms. International Business Review, 26(4), 652665. doi:10.1016/j.ibusrev.2016.12.006

Bai, W. S., Johanson, M., \& Martin, O. M. (2019). Dual business relationships, opportunity knowledge, and new product development: A study on returnee young ventures. Journal of International Marketing, 27(3), 26-42. doi:10.1177/1069031x19852961

Barboza, D. (2006, September 17, 2006). The rise of Baidu (That's Chinese for Google). Retrieved from https://www.nytimes.com/2006/09/17/business/yourmoney/17baidu.html

Barney, J. B., \& Zhang, S. (2009). The future of Chinese management research: A theory of Chinese management versus a Chinese theory of management. Management and Organization Review, 5(1), 15-28. doi:https://doi.org/10.1111/j.17408784.2008.00102.x

Black, J. A., \& Boal, K. B. (1994). Strategic resources: Traits, configurations and paths to sustainable competitive advantage. Strategic Management Journal, 15(S2), 131-148. doi:https://doi.org/10.1002/smj.4250151009

Buckley, P. J., Clegg, L. J., Cross, A. R., Liu, X., Voss, H., \& Zheng, P. (2007). The determinants of Chinese outward foreign direct investment. Journal of International Business $\quad$ Studies, 38(4), 499-518. doi:10.1057/palgrave.jibs. 8400277

Cavusgil, S. T., \& Knight, G. (2015). The born global firm: An entrepreneurial and capabilities perspective on early and rapid internationalization. Journal of International Business Studies, 46(1), 3-16. doi:10.1057/jibs.2014.62

Chang, C., Cheng, A., Kim, S., Kuhn-Osius, J., Reyes, J., \& Turgel, D. (2009, June). Huawei technologies: A Chinese trail blazer in Africa. Retrieved from http://www.businesstoday.lk/article.php?article=931 
Child, J. (2009). Context, comparison, and methodology in Chinese management research. Management and Organization Review, 5(1), 57-73. doi:https://doi.org/10.1111/j.1740-8784.2008.00136.x

Chin, T., Liu, R. H., \& Yang, X. M. (2016). 'Reverse internationalization' in Chinese firms: A study of how global startup OEMs seek to compete domestically. Asia Pacific Business 201-219. doi:10.1080/13602381.2015.1055087

Ciravegna, L., Majano, S. B., \& Zhan, G. (2014). The inception of internationalization of small and medium enterprises: The role of activeness and networks. Journal of Business Research, 67(6), 1081-1089. doi:10.1016/j.jbusres.2013.06.002

Clegg, J., Lin, H. M., Voss, H., Yen, I. F., \& Shih, Y. T. (2016). The OFDI patterns and firm performance of Chinese firms: The moderating effects of multinationality strategy and external factors. International Business Review, 25(4), 971-985. doi:10.1016/j.ibusrev.2016.01.010

Colbert, B. A. (2004). The complex resource-based view: Implications for theory and practice in strategic human resource management. Academy of Management Review, 29(3), 341-358. doi:10.5465/amr.2004.13670987

Coviello, N. E. (2006). The network dynamics of international new ventures. Journal of International Business $\quad$ Studies, 37(5), doi:10.1057/palgrave.jibs.8400219

De Clercq, D., Sapienza, H. J., \& Zhou, L. (2014). Entrepreneurial strategic posture and learning effort in international ventures: The moderating roles of operational flexibilities. International Business Review, 23(5), 981-992. doi:10.1016/j.ibusrev.2014.03.001

De Clercq, D., \& Zhou, L. (2014). Entrepreneurial strategic posture and performance in foreign markets: The critical role of international learning effort. Journal of International Marketing, 22(2), 47-67. doi:https://doi.org/10.1509/jim.13.0131

De Clercq, D., Zhou, L., \& Wu, A. (2016). Unpacking the relationship between young ventures' international learning effort and performance in the context of an emerging economy. International Entrepreneurship and Management Journal, 12(1), 47-66. doi:10.1007/s11365-014-0328-1

Deng, P. (2012). The internationalization of Chinese firms: A critical review and future research. International Journal of Management Reviews, 14(4), 408-427. doi:10.1111/j.1468-2370.2011.00323.X

Deng, Z., Jean, R. J. B., \& Sinkovics, R. R. (2017). Polarizing effects of early exporting on exit. Management International Review, 57(2), 243-275. doi:10.1007/s11575-016-0292-9

Deng, Z., Jean, R. J. B., \& Sinkovics, R. R. (2018). Rapid expansion of international new ventures across institutional distance. Journal of International Business Studies, 49(8), 1010-1032. doi:10.1057/s41267-017-0108-6 
Dodgson, M. (1993). Organizational learning: A review of some literatures. Organization Studies, 14(3), 375-394. doi:https://doi.org/10.1177/017084069301400303

Dzikowski, P. (2018). A bibliometric analysis of born global firms. Journal of Business Research, 85, 281-294. doi:10.1016/j.jbusres.2017.12.054

Ellis, P. D. (2011). Social ties and international entrepreneurship: Opportunities and constraints affecting firm internationalization. Journal of International Business Studies, 42(1), 99-127. doi:10.1057/jibs.2010.20

Fainshmidt, S., Wenger, L., Pezeshkan, A., \& Mallon, M. R. (2019). When do dynamic capabilities lead to competitive advantage? The importance of strategic fit. Journal of Management Studies, 56(4), 758-787. doi:10.1111/joms.12415

Fiss, P. C. (2011). Building better causal theories: A fuzzy set approach to typologies in organization research. Academy of Management Journal, 54(2), 393-420. doi:https://doi.org/10.5465/amj.2011.60263120

Fung, B. (2019, May 16, 2019). US bans Huawei from selling telecom gear and threatens its supply chain. Retrieved from https://edition.cnn.com/2019/05/15/tech/trump-executive-order-telecomsecurity/index.html

Helfat, C. E. (2007). Dynamic capabilities: Foundations. In C. E. Helfat, S. Finkelstein, W. Mitchell, M. Peteraf, H. Singh, D. Teece, \& S. G. Winter (Eds.), Dynamic Capabilities: Understanding Strategic Change in Organizations (pp. 1-18). London: Blackwell Publishing Ltd.

Hull, C. E., Tang, Z., Tang, J., \& Yang, J. (2019). Information diversity and innovation for born-globals. Asia Pacific Journal of Management. doi:10.1007/s10490019-09651-7

Jean, R. J., Kim, D., \& Cavusgil, E. (2020). Antecedents and outcomes of digital platform risk for international new ventures' internationalization. Journal of World Business, 55(1). doi:10.1016/j.jwb.2019.101021

Johanson, J., \& Vahlne, J. E. (2009). The Uppsala internationalization process model revisited: From liability of foreignness to liability of outsidership. Journal of International Business Studies, 40(9), 1411-1431. doi:10.1057/jibs.2009.24

Johnson, J. E. (2004). Factors influencing the early internationalization of high technology start-ups: US and UK evidence. Journal of International Entrepreneurship, 2(1-2), 139-154. doi:10.1023/B:JIEN.0000026910.87323.4e

Jones, M. V., Coviello, N., \& Tang, Y. K. (2011). International Entrepreneurship research (1989-2009): A domain ontology and thematic analysis. Journal of Business Venturing, 26(6), 632-659. doi:10.1016/j.jbusvent.2011.04.001

Kantar. (2019). BrandZ ${ }^{\text {TM }}$ top 100 most valuable Chinese brands 2019. Retrieved from London: http://brandz.com/admin/uploads/files/BZ_China_2019_EN_DL.pdf

Keupp, M. M., \& Gassmann, O. (2009). The Past and the Future of International Entrepreneurship: A Review and Suggestions for Developing the Field. Journal of Management, 35(3), 600-633. doi:10.1177/0149206308330558 
Khavul, S., Perez-Nordtvedt, L., \& Wood, E. (2010). Organizational entrainment and international new ventures from emerging markets. Journal of Business Venturing, 25(1), 104-119. doi:10.1016/j.jbusvent.2009.01.008

Khavul, S., Peterson, M., Mullens, D., \& Rasheed, A. A. (2010). Going global with innovations from emerging economies: Investment in customer support capabilities pays off. Journal of International Marketing, 18(4), 22-42. doi:10.1509/jimk.18.4.22

Khavul, S., Prater, E., \& Swafford, P. M. (2012). International responsiveness of entrepreneurial new ventures from three leading emerging economies. International Journal of Operations and Production Management, 32(10), 11471177. doi:10.1108/01443571211274503

Kiss, A. N., Danis, W. M., \& Cavusgil, S. T. (2012). International entrepreneurship research in emerging economies: A critical review and research agenda. Journal of Business Venturing, 27(2), 266-290. doi:10.1016/j.jbusvent.2011.09.004

Knight, G. A., \& Cavusgil, S. T. (2004). Innovation, organizational capabilities, and the born-global firm. Journal of International Business Studies, 35(2), 124-141. doi:10.1057/palgrave.jibs.8400071

Li, C., He, C., \& Lin, C. (2018). Economic impacts of the possible China-US trade war. Emerging Markets Finance and Trade, 54(7), 1557-1577. doi:https://doi.org/10.1080/1540496X.2018.1446131

Lin, S., Mercier-Suissa, C., \& Salloum, C. (2016). The Chinese born globals of the Zhejiang Province: A study on the key factors for their rapid internationalization. Journal of International Entrepreneurship, 14(1), 75-95. doi:10.1007/s10843-016-0174-z

Lin, S., \& Si, S. (2019). The influence of exploration and exploitation on born globals' speed of internationalization. Management Decision, 57(1), 193-210. doi:10.1108/MD-08-2017-0735

Liu, T., \& Woo, W. T. (2018). Understanding the US-China trade war. China Economic Journal, 11(3), 319-340. doi:https://doi.org/10.1080/17538963.2018.1516256

Liu, X., Xiao, W., \& Huang, X. (2008). Bounded entrepreneurship and internationalisation of indigenous Chinese private-owned firms. International Business Review, 17(4), 488-508. doi:10.1016/j.ibusrev.2008.02.014

Liu, Y., Li, Y., \& Xue, J. (2011). Ownership, strategic orientation and internationalization in emerging markets. Journal of World Business, 46(3), 381-393. doi:https://doi.org/10.1016/j.jwb.2010.07.012

Liu, Y. P. (2017). Born global firms' growth and collaborative entry mode: The role of transnational entrepreneurs. International Marketing Review, 34(1), 46-67. doi:10.1108/imr-05-2015-0130

Lu, Y., Zhou, L., Bruton, G., \& Li, W. (2010). Capabilities as a mediator linking resources and the international performance of entrepreneurial firms in an 
emerging economy. Journal of International Business Studies, 41(3), 419-436. doi:10.1057/jibs.2009.73

Mcdougall, P. P. (1989). International versus domestic entrepreneurship - New venture strategic behavior and industry structure. Journal of Business Venturing, 4(6), 387-400. doi:10.1016/0883-9026(89)90009-8

McDougall, P. P., \& Oviatt, B. M. (2000). International entrepreneurship: The intersection of two research paths. Academy of Management Journal, 43(5), 902-906. doi:10.5465/1556418

Mcdougall, P. P., Shane, S., \& Oviatt, B. M. (1994). Explaining the formation of international new ventures - The limits of theories from international-business research. Journal of Business Venturing, 9(6), 469-487. doi:http://dx.doi.org/10.1016/0883-9026(94)90017-5

Mellahi, K., \& Sminia, H. (2009). Guest editors' introduction: The frontiers of strategic management research. International Journal of Management Reviews, 11(1), 17. doi:https://doi.org/10.1111/j.1468-2370.2008.00248.x

Mikalef, P., \& Pateli, A. (2017). Information technology-enabled dynamic capabilities and their indirect effect on competitive performance: Findings from PLS-SEM and fsQCA. Journal of Business Research, 70, 1-16. doi:https://doi.org/10.1016/j.jbusres.2016.09.004

Morse, E. A., Fowler, S. W., \& Lawrence, T. B. (2007). The impact of virtual embeddedness on new venture survival: Overcoming the liabilities of newness. Entrepreneurship Theory and Practice, 31(2), 139-159. doi:https://doi.org/10.1111/j.1540-6520.2007.00167.x

Naudé, W., \& Rossouw, S. (2010). Early international entrepreneurship in China: Extent and determinants. Journal of International Entrepreneurship, 8(1), 87-111. doi:10.1007/s10843-010-0049-7

NBSC, N. B. o. S. o. C. (2018). China Statistical Yearbook 2018. Beijing: China statistics press.

Oviatt, B. M., \& Mcdougall, P. P. (1994). Toward a Theory of International New Ventures. Journal of International Business Studies, 25(1), 45-64. doi:10.1057/palgrave.jibs.8490193

Oviatt, B. M., \& McDougall, P. P. (1995). Global start-ups: Entrepreneurs on a worldwide stage. Academy of Management Perspectives, 9(2), 30-43. doi:https://doi.org/10.5465/ame.1995.9506273269

Pangestu, M. (2019). China-US trade War: An Indonesian perspective. China Economic Journal, 12(2), 208-230. doi:10.1080/17538963.2019.1611084

Podsakoff, P. M., MacKenzie, S. B., Bachrach, D. G., \& Podsakoff, N. P. (2005). The influence of management journals in the 1980s and 1990s. Strategic Management Journal, 26(5), 473-488. doi:https://doi.org/10.1002/smj.454

Puffer, S. M., McCarthy, D. J., \& Boisot, M. (2010). Entrepreneurship in Russia and China: The impact of formal institutional voids. Entrepreneurship Theory and 
Practice, 34(3), 441-467. doi:https://doi.org/10.1111/j.15406520.2009.00353.x

Qian, G., Li, L., \& Qian, Z. (2018). Interactions among factors driving and inhibiting the early internationalization of small, young technology enterprises. Management International Review, 58(2), 251-280. doi:10.1007/s11575-017-0321-3

Qiu, L. D., \& Wei, X. (2019). China-US trade: Implications on conflicts. China Economic Journal. doi:10.1080/17538963.2019.1598014

Rialp, A., Rialp, J., \& Knight, G. A. (2005). The phenomenon of early internationalizing firms: What do we know after a decade (1993-2003) of scientific inquiry? International Business Review, 14(2), 147-166. doi:10.1016/j.ibusrev.2004.04.006

Rihoux, B., \& Ragin, C. C. (2009a). Configurational comparative methods: Qualitative comparative analysis (QCA) and related techniques. California: SAGE Publications, Inc.

Rihoux, B., \& Ragin, C. C. (2009b). Qualitative comparative analysis using fuzzy sets (fsQCA). In Configurational comparative methods: Qualitative comparative analysis (QCA) and related techniques. California: SAGE Publications, Inc.

Romanello, R., \& Chiarvesio, M. (2019). Early internationalizing firms: 2004-2018. Journal of International Entrepreneurship, 17(2), 172-219. doi:10.1007/s10843018-0241-8

Semin, A. N., Kostyaev, A. I., Truba, A. S., Ponkratov, V. V., \& Gagarina, M. V. (2019). Economic ramifications of China-United States trade war for the Russian Federation. China Economic Journal, 12(3), 316-335. doi:10.1080/17538963.2019.1591573

Sjodin, D. R., Parida, V., \& Kohtamaki, M. (2016). Capability configurations for advanced service offerings in manufacturing firms: Using fuzzy set qualitative comparative analysis. Journal of Business Research, 69(11), 5330-5335. doi:10.1016/j.jbusres.2016.04.133

Su, J. (2018, April 19, 2018). Analyst: China's Huawei to exit U.S. market. Retrieved from https://www.forbes.com/sites/jeanbaptiste/2018/04/19/analyst-chinashuawei-to-quit-u-s-market/\#56eb87b11cb7

Tan, H., \& Mathews, J. A. (2015). Accelerated internationalization and resource leverage strategizing: The case of Chinese wind turbine manufacturers. Journal of World Business, 50(3), 417-427. doi:10.1016/j.jwb.2014.05.005

Tang, Y. K. (2011). The influence of networking on the internationalization of SMEs: Evidence from internationalized Chinese firms. International Small Business Journal, 29(4), 374-398. doi:10.1177/0266242610369748

Teece, D. J. (2014). The foundations of enterprise performance: Dynamic and ordinary capabilities in an (economic) theory of firms. Academy of Management Perspectives, 28(4), 328-352. doi:10.5465/amp.2013.0116 
Tranfield, D., Denyer, D., \& Smart, P. (2003). Towards a methodology for developing evidence-informed management knowledge by means of systematic review. British Journal of Management, 14(3), 207-222. doi:https://doi.org/10.1111/1467-8551.00375

Tsukanova, T., \& Zhang, X. (2019). Early and rapid internationalization of firms from emerging economies: Understanding the heterogeneity of Chinese exporters. Journal of East-West Business. doi:10.1080/10669868.2018.1548405

UNCTAD. (2019). World Investment Report 2019. Retrieved from Geneva: https://unctad.org/en/PublicationsLibrary/wir2019_en.pdf

Vissak, T., \& Zhang, X. (2016). Guanxi's changing nature: A Chinese born global's experience. Journal of East-West Business, 22(4), 270-295. doi:10.1080/10669868.2016.1215661

Wang, C. H., Hsu, L. C., \& Fang, S. R. (2008). The determinants of internationalization: Evidence from the Taiwan high technology industry. Technological Forecasting and Social Change, 75(9), 1388-1395. doi:10.1016/j.techfore.2008.03.002

Wang, C. L., \& Chugh, H. (2014). Entrepreneurial learning: Past research and future challenges. International Journal of Management Reviews, 16(1), 24-61. doi:https://doi.org/10.1111/ijmr.12007

Wang, H. H. (2014, July 17). Alibaba saga III: Jack Ma discovered the Internet. Retrieved from https:/www.forbes.com/sites/helenwang/2014/07/17/alibabasaga-iii/\#685a4aa53058

Winter, S. G. (2003). Understanding dynamic capabilities. Strategic Management Journal, 24(10), 991-995. doi:https://doi.org/10.1002/smj.318

WIPO. (2019). World Intellectual Property Indicators 2019. Retrieved from Geneva: https://www.wipo.int/edocs/pubdocs/en/wipo_pub_941_2019.pdf

Witt, M. A. (2019). China's challenge: Geopolitics, de-globalization, and the future of Chinese business. Management and Organization Review, 1-18. doi:10.1017/mor.2019.49

Wood, E., Khavul, S., Perez-Nordtvedt, L., Prakhya, S., Velarde Dabrowski, R., \& Zheng, C. (2011). Strategic commitment and timing of internationalization from emerging markets: Evidence from China, India, Mexico, and South Africa. Journal of Small Business Management, 49(2), 252-282. doi:10.1111/j.1540627X.2011.00324.X

Wu, A., \& Voss, H. (2015). When does absorptive capacity matter for international performance of firms? Evidence from China. International Business Review, 24(2), 344-351. doi:10.1016/j.ibusrev.2014.08.006

Wu, A. Q., \& Zhou, L. X. (2018). Understanding earliness of internationalization and its impact on postentry geographic diversity of international young ventures. Journal of International Marketing, 26(2), 62-79. doi:10.1509/jim.16.0123 
Yamakawa, Y., Khavul, S., Peng, M. W., \& Deeds, D. L. (2013). Venturing from emerging economies. Strategic Entrepreneurship Journal, 7(3), 181-196. doi:10.1002/sej.1158

Yang, J. Y., \& Li, J. (2008). The development of entrepreneurship in China. Asia Pacific Journal of Management, 25(2), 335-359. doi:10.1007/s10490-007-9078-8

Zadeh, L. A. (1965). Fuzzy sets. Information and control, 8(3), 338-353. doi:https://doi.org/10.1016/S0019-9958(65)90241-X

Zaheer, S. (1995). Overcoming the liability of foreignness. Academy of Management Journal, 38(2), 341-363. doi:https://doi.org/10.5465/256683

Zahra, S. A. (2005). A theory of international new ventures: A decade of research. Journal of International Business Studies, 36(1), 20-28. doi:10.1057/palgrave.jibs.8400118

Zahra, S. A., Ireland, R. D., \& Hitt, M. A. (2000). International expansion by new venture firms: International diversity, mode of market entry, technological learning, and performance. Academy of Management Journal, 43(5), 925-950. doi:10.2307/1556420

Zahra, S. A., Sapienza, H. J., \& Davidsson, P. (2006). Entrepreneurship and dynamic capabilities: A review, model and research agenda. Journal of Management Studies, 43(4), 917-955. doi:https://doi.org/10.1111/j.1467-6486.2006.00616.x

Zhang, M., Gao, Q., \& Cho, H. S. (2017). The effect of sub-national institutions and international entrepreneurial capability on international performance of exportfocused SMEs: Evidence from China and South Korea. Journal of International Entrepreneurship, 15(1), 85-110. doi:10.1007/s10843-016-0196-6

Zhang, M., Gao, Q., Wheeler, J. V., \& Kwon, J. (2016). Institutional effect on born global firms in China: The role of Sun Tzu's The Art of War strategies. Journal of Asia Business Studies, 10(1), 1-19. doi:10.1108/JABS-11-2014-0084

Zhang, M., \& Hartley, J. (2018). Does guanxi influence product performance and customer loyalty? Journal of Asia Business Studies, 12(3), 233-252. doi:10.1108/JABS-06-2016-0082

Zhang, M., Tansuhaj, P., \& McCullough, J. (2009). International entrepreneurial capability: The measurement and a comparison between born global firms and traditional exporters in China. Journal of International Entrepreneurship, 7(4), 292-322. doi:10.1007/s10843-009-0042-1

Zhang, X., Ma, X., \& Wang, Y. (2012). Entrepreneurial orientation, social capital, and the internationalization of SMEs: Evidence from China. Thunderbird International Business $\quad$ Review, 54(2), 195-210. doi:https://doi.org/10.1002/tie.21451

Zhou, L. (2007). The effects of entrepreneurial proclivity and foreign market knowledge on early internationalization. Journal of World Business, 42(3), 281-293. doi:10.1016/j.jwb.2007.04.009 
Zhou, L., Barnes, B. R., \& Lu, Y. (2010). Entrepreneurial proclivity, capability upgrading and performance advantage of newness among international new ventures. Journal of International Business Studies, 41(5), 882-905. doi:10.1057/jibs.2009.87

Zhou, L., \& Wu, A. (2014). Earliness of internationalization and performance outcomes: Exploring the moderating effects of venture age and international commitment. Journal of World Business, 49(1), 132-142. doi:10.1016/j.jwb.2013.10.001

Zhou, L., Wu, A., \& Barnes, B. R. (2012). The effects of early internationalization on performance outcomes in young international ventures: The mediating role of marketing capabilities. Journal of International Marketing, 20(4), 25-45. doi:10.1509/jim.12.0076

Zhou, L. X., Wu, W. P., \& Luo, X. M. (2007). Internationalization and the performance of born-global SMEs: The mediating role of social networks. Journal of International Business $\quad$ Studies, 38(4), 673-690. doi:10.1057/palgrave.jibs.8400282

Zhu, Y., Wittmann, X., \& Peng, M. W. (2012). Institution-based barriers to innovation in SMEs in China. Asia Pacific Journal of Management, 29(4), 1131-1142. doi:10.1007/s10490-011-9263-7

Zollo, M., \& Winter, S. G. (2002). Deliberate learning and the evolution of dynamic capabilities. Organization Science, 13(3), 339-351.

Zou, H., \& Ghauri, P. N. (2010). Internationalizing by learning: The case of Chinese high-tech new ventures. International Marketing Review, 27(2), 223-244. doi:10.1108/02651331011037539 


\section{Appendix}

List of the 42 articles analysed for the literature review.

\begin{tabular}{|c|c|c|}
\hline \# & Author(s) & Journal \\
\hline 1. & Zhou (2007) & Journal of World Business \\
\hline 2. & Zhou, Wu, and Luo (2007) & $\begin{array}{l}\text { Journal of International Business } \\
\text { Studies }\end{array}$ \\
\hline 3. & Liu, xiao, and Huang (2008) & International Business Review \\
\hline 4. & $\begin{array}{l}\text { Zhang, Tansuhaj, and } \\
\text { McCullough (2009) }\end{array}$ & $\begin{array}{l}\text { Journal of International } \\
\text { Entrepreneurship }\end{array}$ \\
\hline 5. & $\begin{array}{l}\text { Khavul, Perez-Nordtvedt, and } \\
\text { Wood (2010)* }\end{array}$ & Journal of Business Venturing \\
\hline 6. & $\begin{array}{l}\text { Khavul, Peterson, Mullens, and } \\
\text { Rasheed }(2010)^{*}\end{array}$ & Journal of International Marketing \\
\hline 7. & Lu, Zhou, Bruton, and Li (2010) & $\begin{array}{l}\text { Journal of International Business } \\
\text { Studies }\end{array}$ \\
\hline 8. & Naudé and Rossouw (2010) & $\begin{array}{l}\text { Journal of International } \\
\text { Entrepreneurship }\end{array}$ \\
\hline 9. & Zhou, Barnes, and Lu (2010) & $\begin{array}{l}\text { Journal of International Business } \\
\text { Studies }\end{array}$ \\
\hline 10. & Zou and Ghauri (2010) & International Marketing Review \\
\hline 11. & Ellis (2011) & $\begin{array}{l}\text { Journal of International Business } \\
\text { Studies }\end{array}$ \\
\hline 12. & Tang (2011) & International Small Business Journal \\
\hline 13. & Wood, et al. (2011)* & Journal of Small Business Management \\
\hline 14. & $\begin{array}{l}\text { Khavul, Prater, and Swafford } \\
(2012)^{*}\end{array}$ & $\begin{array}{l}\text { International Journal of Operations and } \\
\text { Production Management }\end{array}$ \\
\hline 15. & Zhou, Wu, and Barnes (2012) & Journal of International Marketing \\
\hline 16. & Su (2013) & $\begin{array}{l}\text { MIS Quarterly: Management } \\
\text { Information Systems }\end{array}$ \\
\hline 17. & $\begin{array}{l}\text { Yamakawa, Khavul, Peng, and } \\
\text { Deeds }(2013)^{*}\end{array}$ & Strategic Entrepreneurship Journal \\
\hline 18. & $\begin{array}{l}\text { Ciravegna, Majano, and Zhan } \\
\text { (2014) }\end{array}$ & Journal of Business Research \\
\hline 19. & $\begin{array}{l}\text { De Clercq, Sapienza, and Zhou } \\
\text { (2014) }\end{array}$ & International Business Review \\
\hline 20. & De Clercq and Zhou (2014) & Journal of International Marketing \\
\hline 21. & Zhou and Wu (2014) & Journal of World Business \\
\hline 22. & Tan and Mathews (2015) & Journal of World Business \\
\hline 23. & Wu and Voss (2015) & International Business Review \\
\hline 24. & $\begin{array}{l}\text { Bai, Holmström Lind, and } \\
\text { Johanson (2016) }\end{array}$ & $\begin{array}{l}\text { Entrepreneurship and Regional } \\
\text { Development }\end{array}$ \\
\hline 25. & $\begin{array}{l}\text { Clegg, Lin, Voss, Yen, and Shih } \\
(2016)\end{array}$ & International Business Review \\
\hline
\end{tabular}




\begin{tabular}{|c|c|c|}
\hline 26. & De Clercq, Zhou, and Wu (2016) & $\begin{array}{l}\text { International Entrepreneurship and } \\
\text { Management Journal }\end{array}$ \\
\hline 27. & $\begin{array}{l}\text { Lin, Mercier-Suissa, and Salloum } \\
\text { (2016) }\end{array}$ & $\begin{array}{l}\text { Journal of International } \\
\text { Entrepreneurship }\end{array}$ \\
\hline 28. & Vissak and Zhang (2016) & Journal of East-West Business \\
\hline 29. & $\begin{array}{l}\text { Zhang, Gao, Wheeler, and Kwon } \\
\text { (2016) }\end{array}$ & Journal of Asia Business Studies \\
\hline 30. & $\begin{array}{l}\text { Bai, Johanson, and Martín Martín } \\
\text { (2017) }\end{array}$ & International Business Review \\
\hline 31. & Deng, Jean, and Sinkovics (2017) & Management International Review \\
\hline 32. & Liu (2017) & International Marketing Review \\
\hline 33. & Zhang, Gao, and Cho (2017) & $\begin{array}{l}\text { Journal of International } \\
\text { Entrepreneurship }\end{array}$ \\
\hline 34. & Deng, Jean, and Sinkovics (2018) & $\begin{array}{l}\text { Journal of International Business } \\
\text { Studies }\end{array}$ \\
\hline 35. & Qian, Li, and Qian (2018) & Management International Review \\
\hline 36. & Wu and Zhou (2018) & Journal of International Marketing \\
\hline 37. & Zhang and Hartley (2018) & Journal of Asia Business Studies \\
\hline 38. & Bai, Johanson, and Martin (2019) & Journal of International Marketing \\
\hline 39. & $\begin{array}{l}\text { Hull, Tang, Tang, and Yang } \\
\text { (2019) }\end{array}$ & Asia Pacific Journal of Management \\
\hline 40. & Lin and $\mathrm{Si}$ (2019) & Management Decision \\
\hline 41. & Tsukanova and Zhang (2019) & Journal of East-West Business \\
\hline 42. & Jean, Kim, and Cavusgil (2020) & Journal of World Business \\
\hline
\end{tabular}

Note: * Cross-country comparison study; Chronologically ordered. 
Early Internationalizing Firms' Capabilities 


\section{CHAPTER 3 \\ Capabilities and \\ Early Internationalizing Firms' \\ Performance: A Systematic Literature Review}

An early version of the chapter has been presented as:

Jie, S., \& Harms, R. (2018, 2018/06/25). Capabilities and international startups' international performance: Categorization model and a systematic literature review. Paper presented at the EURAM Conference 2018: Research in Action-Accelerating knowledge creation in management, Reykjavik.

Jie, S., \& Harms, R. (2018, 2018/07/01). Capabilities and international startups' international performance: A systematic literature review. Paper presented at the Academy of Management Proceedings, Chicago.

This chapter is prepared for submission to Journal of Small Business Management. 


\subsection{Introduction}

Young companies that internationalize fast and early are known as 'international new ventures' (INVs, McDougall, 1989; Ojala, Evers, \& Rialp, 2018), 'global startups' (Oviatt \& McDougall, 1995), 'born globals' (BGs, Knight \& Cavusgil, 1996; Knight \& Liesch, 2016), or 'international startups' (Han, 2006). For an overview of the synonymous terms, please refer to Dzikowski (2018). These terms overlap and, at their core, address essentially the same phenomenon (Svensson, 2006). Here, we use the umbrella term 'early internationalizing firms' (EIFs, Rialp, Rialp, \& Knight, 2005, p. 148), to counter the "unnecessary proliferation of terms that vary in insignificant ways" (Svensson \& Payan, 2009, p. 409) and provide a common language that addresses the same phenomenon to all intents and purposes.

EIFs exert a significant economic impact. For example, EIFs account for 40-50 per cent of young firms in Belgium and Denmark, and 15-20 per cent of startups in the US and UK (Eurofound, 2012). The Global Entrepreneurship Monitor shows that EIFs have stronger positive employment effects than other startups (Mets, 2014). In the US, 86 per cent of technology-based startups are EIFs (Manyika et al., 2016). Worldwide, EIFs create 360 million jobs (Smith, 2016). Also, startups that fail to internationalize early lose two-thirds of their potential customers (Fertik, 2013).

Because EIFs provide value, it is not surprising that the question of how EIFs achieve international performance is one of the most frequently studied topics in international entrepreneurship research (IE, Jones, Coviello, \& Tang, 2011; Keupp \& Gassmann, 2009). In research on EIF performance, the capabilitybased perspective (CBP, Teece, Pisano, \& Shuen, 1997) is a well-established theoretical lens (Al-Aali \& Teece, 2014; Knight \& Cavusgil, 2004; Weerawardena, Mort, Liesch, \& Knight, 2007). Rapid developments in IE practice and research make this an excellent opportunity to revisit the literature at the interface where the CBP and the international performance of EIFs meet. Keeping track of which capabilities have been researched is necessary because an uncharted research field thwarts a better understanding of theory and practice (Reuber, Dimitratos, \& Kuivalainen, 2017) in terms of EIF capabilities. Also, Low and MacMillan (1988) make the general but no less valid point that a periodical review of a particular field is necessary to guide future research. 
Hence, one purpose of this study is to provide a review of the capabilities that EIFs use to achieve international performance.

Such a review is based on a categorization model of capabilities. We develop and use this categorization model to address the ambiguity in capability terminology that has proliferated (Thomas \& Pollock, 1999; Wang \& Ahmed, 2007). This proliferation can be seen in the array of capability terminologies drawn from the original SCs and DCs. For example, there is considerable ambiguity over the basic terminology of whether research has been addressing substantive or dynamic capabilities (Wang \& Ahmed, 2007). Hence, the second purpose of this study is to provide a categorization model for capabilities research.

Based on this model, we consolidated research on EIFs and international performance, establish connections in this nascent research stream (Jones et al., 2011), and identify several research gaps (Crossan \& Apaydin, 2010). Here, we emphasize which capabilities have been most frequently studied, and which capabilities have remained under-researched, and we highlight research gaps that could usefully be filled.

\subsection{The theoretical background of the capability categorization model}

\subsubsection{The CBP in IE research}

IE research has a strong foundation in the CBP. This capability-based perspective holds that a firm's heterogeneity in conducting functional-directed behaviours can drive performance differences (Teece, 2007; Teece et al., 1997). A capability is "a learned and stable pattern of collective activity" (Zollo \& Winter, 2002, p. 340) at the level of the firm. The two basic types of capabilities are substantive capabilities (SCs) and dynamic capabilities (DCs).

Substantive capabilities (Zahra, Sapienza, \& Davidsson, 2006) are capabilities that utilize available resources to accomplish tasks to create value, at least for the short term, for the organization. This definition is a composite of several definitions (Teece, 2014; Winter, 2003; Zahra et al., 2006) of capabilities that are also known as static (Collis, 1996), zero-level (Winter, 2003), operational (Helfat \& Peteraf, 2003), and ordinary capabilities (Teece, 2012). SCs are used to perform administrative, operational, and governance functions that allow 
firms to accomplish tasks of a higher quality and with lower cost (Teece, 2014). SCs and EIFs are positively related in terms of international performance (Martin \& Javalgi, 2016a; Ripolles, Blesa, \& Monferrer, 2012; Zhang, Tansuhaj, \& McCullough, 2009). For example, (international) marketing capabilities help EIFs to acquire customers and to effectively manage markets, which in turn benefit their (international) performance (Ripolles et al., 2012).

Dynamic capabilities are "the capacity of an organization to purposefully create, extend, or modify its resource base" (Helfat, 2007, p. 1). DCs are used to sense environmental changes, formulate a response to the change, and then take action to implement the response (Teece, 2014). DCs contribute to firm performance by configuring firm resources and SCs in order to address and shape rapidly changing environments (Weerawardena, Mort, Salunke, Knight, \& Liesch, 2014; Zhou, Wu, \& Barnes, 2012). For instance, DCs on network learning, market learning, and marketing contribute to innovativeness and early internationalization (Weerawardena et al., 2014). These DCs help firm to acquire internationalization knowledge to reduce uncertainty in international markets, to obtain experiential knowledge to identify opportunities, and to transfer that knowledge into resources, skills, and activities to meet customer needs.

To further categories capabilities, an internal/external distinction is vital (Helfat, 2007; Zahra \& Nielsen, 2002) since internal and external resources are the foundation of a firm's capabilities (Grant, 2016; Wernerfelt, 1984). SCs that are internally oriented refer to activities that help a firm to perform its internally oriented operational and administrative activities (technical efficiency). SCs that are externally oriented refer to activities that help a firm to perform its externally oriented operational and administrative activities (external fit, Helfat, 2007, p. 7). In the case of DCs, 'technical fitness' refers to the degree of effectiveness of a firm in performing its internal functions (Helfat, 2007). We use 'evolutionary fitness' to address "how well a dynamic capability enables an organization to make a living by creating, extending or modifying its resource base" (Helfat, 2007 , p. 7). We differentiate the types of capabilities using the dimension of performance (i.e., technical efficiency, external fit, technical fitness, and evolutionary fitness) that they impact (see Figure 3.1 for a summary). 


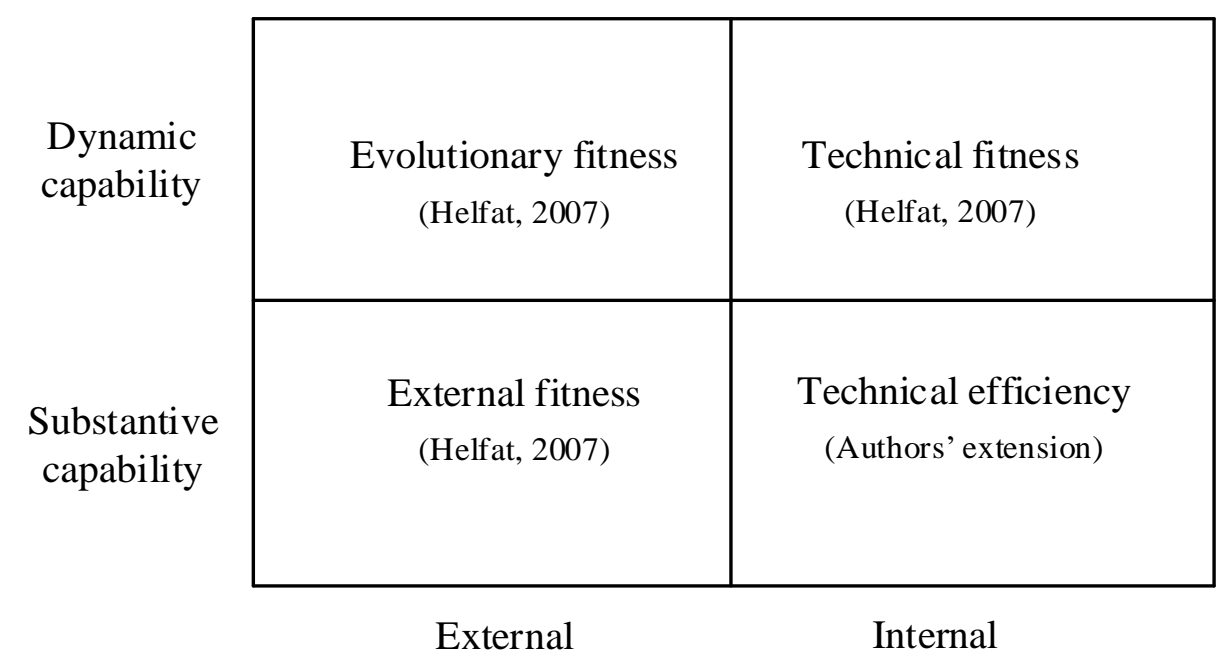

Figure 3.1. Performance implications of SCs and DCs along the internal and external dimension.

\subsubsection{Categorizing substantive capabilities}

Based on the distinction between internally and externally oriented activities (see Figure 3.1), we categories SCs along three dimensions. The first dimension is whether activities address internal or external transactions (see the previous section). The second dimension is based on a distinction between operational and administrative activities. Mintzberg (1980, p. 323) and Nelson and Winter (1982) distinguish between a firm's operating core and its strategic apex. Operational activities refer to production and organisation, while administrative activities coordinate processes so that things are done right, such as 'direct supervision,' 'standardization of work process,' 'standardization of outputs,' 'standardization of skills,' and 'mutual adjustment' (Mintzberg, 1980, p. 323). The operational/administrative dimension also supports theoretical foundations for the ordinary (substantive) capabilities that Teece (2014, p. 331) refers to as "achieving technical efficiency and 'doing things right' in the core business functions of operations, administration, and governance."

The third dimension refers to whether activities are oriented towards the international or the domestic market. Addressing the international market is the hallmark of EIFs. Empirical evidence shows that capabilities dealing with international operations and administration contribute to the international 
performance of EIFs (Boso, Oghazi, \& Hultman, 2017; Mathews, Bianchi, Perks, Healy, \& Wickramasekera, 2016). However, capabilities related to operational and administrative activities in the domestic market matter as well (Dimitratos, Lioukas, \& Carter, 2004; Karafyllia \& Zucchella, 2017; Liu, Gao, Lu, \& Lioliou, 2016). A firm's capabilities of combining upstream elements in the value chain to (co-)create value (with) for specific client groups and their national contacts in the business ecosystem are vital for healthy performance in international markets (Priem, Butler, \& Li, 2013). Additionally, a strong domestic business lays the foundation from which a company can then expand internationally. For example, multinational enterprises from emerging economies tend to nurture their supplying and competing capabilities in the domestic market to lay down a base before embarking on internationalization (Li Sun, 2009).

In sum, four categories of SCs address externally oriented activities: (1) capabilities related to international market operations; (2) capabilities related to domestic market operations; (3) capabilities related to international market administration; (4) capabilities related to domestic market administration. Additionally, two categories of SCs address internally oriented activities: (5) capabilities related to internal operations; and (6) capabilities related to internal administration. Figure 3.2 presents the categorization model and generic types of SCs.

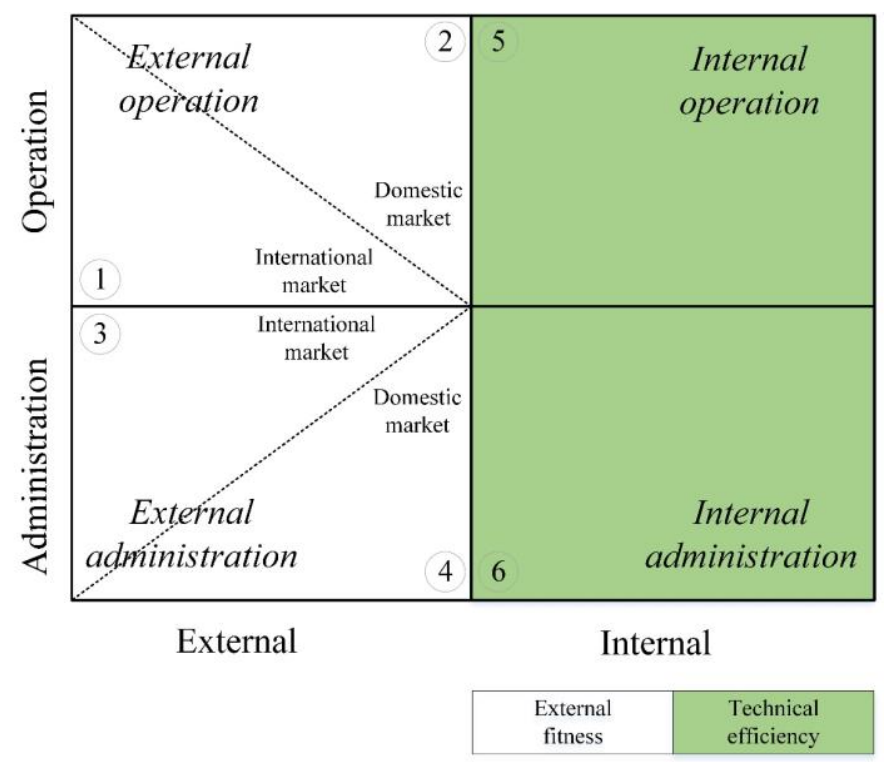

Figure 3.2. The categorization model and generic types of SCs. 
SCs relate to international market operations and administration (quadrants (1) and (3) promote EIFs' operations and administration related to international markets. SCs related to international market operations include activities such as pricing, selling, distributing, and implementing marketing campaigns. International marketing capability represents this category. For example, an EIF's international marketing capabilities, which employ the firm's collective knowledge on international-market needs, create a positional advantage and promote export performance over time (Martin, Javalgi, \& Cavusgil, 2017). SCs related to international market administration are those that support the firm's administrative activities. Activities include coordinating, maintaining, and expanding international networks. International networking capability (Coviello \& Munro, 1995) and international marketing channel management capability (Boso et al., 2017) are the two representative capabilities.

SCs relate to domestic market operations and administration (quadrants (2) and (4)) facilitate EIFs in executing operational and administrative activities related to domestic markets. Such activities include those that coordinate the firm's domestic supply chain when orders from international markets come in. SCs related to domestic market administration are activities that firms conduct to manage internal resources. For instance, organizations' human-resourcemanagement capabilities positively influence their performance (Meyer \& Xin, 2018).

SCs that concern with internal operations and administration (quadrants (5) and (6) are related to operational and administrative activities that focus on internal transactions. Capabilities related to internal operations consist of SCs that sustain the firm's operational activities, such as production and supporting activities. For example, an IT capability helps EIFs to "turn information technology into customer value" (Glavas, Mathews, \& Bianchi, 2017), therefore increasing their international market share and stimulating sales growth (Glavas et al., 2017). SCs related to internal administrations include those that maintain and increase administrative efficiencies, such as daily management capability and HRM capability. For example, EIFs' management capabilities - a complex bundle of daily management skills, e.g., cost control and financial management skills drive its short-term financial and long-term strategic performance in the international market (Efrat \& Shoham, 2012). 


\subsubsection{Categorizing dynamic capabilities}

To categories DCs, the criteria of internal/external and of international/domestic also apply. An additional dimension refers to the strategic functions of exploration and exploitation. Exploration and exploitation are the two strategic logics for DCs (Benner \& Tushman, 2003; Eisenhardt \& Martin, 2000). Exploration refers to "learning gained through processes of concerted variation, planned experimentation, and play"; Exploitation refers to "learning gained via local search, experiential refinement, and selection of existing routines" (Baum, Li, \& Usher, 2000, p. 768). Accordingly, international and domestic market observation and evaluation activities (searching) belong to exploration, and international and domestic market resource-acquisition activities (executing) belong to exploitation. Such a categorization is consistent with the explorative and exploitative internationalization capabilities advanced by Prange and Verdier (2011).

Accordingly, four categories of DCs address externally oriented activities: (7) capabilities related to international market observation and evaluation; (8) capabilities related to domestic market observation and evaluation; (9) capabilities related to international market resource acquisition; (10) capabilities related to domestic market resource acquisition. Two DC categories address internally oriented activities: (11) capabilities related to resource renewal, and (12) capabilities related to resource reconfiguration. Figure 3.3 presents the categorization model and the generic types of DCs.

DCs relate to international market observation and evaluation, and resource acquisition (quadrants (7) and (9) contribute to a firm's performance in international markets. For example, capabilities related to international market observation and evaluation help to improve a firm's international market fitness and to identify new opportunities in international markets (Madsen, 2010). A firm's ability "to learn about its market environment and use this knowledge to guide its actions" contributes positively to a firm's international growth (Zhou et al., 2012, p. 26). Capabilities related to international resource acquisition facilitate firms in acquiring resources from international markets, through approaches such as cooperation with firms in the target markets. For instance, a dynamic networking capability enables EIFs to identify and exploit market opportunities and facilitates the development of knowledge-intensive products, which then contributes to their international market performance (Mort \& Weerawardena, 2006). 


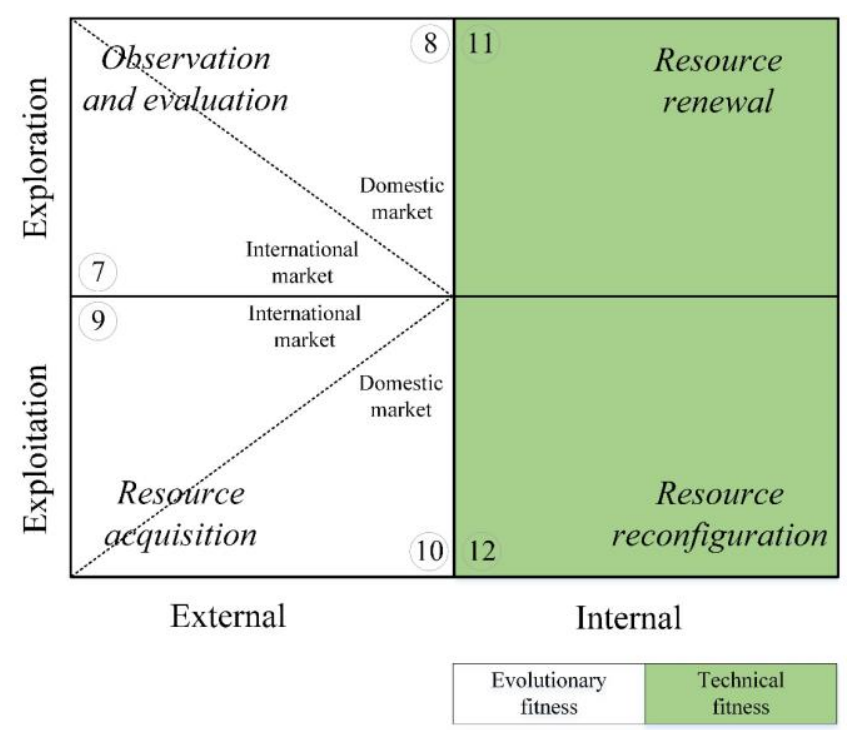

Figure 3.3. The categorization model and generic types of DCs.

DCs relate to domestic market observation and evaluation, and resource acquisition (quadrants (8) and (10) promote the performance of firms in the domestic market. Such capabilities are targeted at finding opportunities and new resources in domestic markets (Weerawardena, 2003). Capabilities related to domestic resource acquisition help EIFs to secure a relative advantage through reducing costs (e.g., labor or raw materials). Developing and maintaining an alliance in the domestic market makes the resource acquisition process more efficient (Kondo, 2005).

DCs relate to internal resource renewal, and resource reconfiguration (quadrants (11) and (12)) help the firm to perform its internal functions. Capabilities related to internal resource renewal modify product development routines, decisionmaking procedures, and previous knowledge and experience (Madsen, 2010). For example, the IT capability of EIFs, which combines newly acquired resources with previous resources, contributes to their international performance (Zhang, Sarker, \& Sarker, 2013). Capabilities related to internal resource reconfiguration comprise DCs that help to reconfigure resources. These DCs promote new valuable resource combinations, which are crucial for sustaining competitiveness in dynamic environments (Teece et al., 1997). Resource-based reconfigurations contribute significantly to (perceived) international performance (Jantunen, Puumalainen, Saarenketo, \& Kyläheiko, 2005). 


\subsection{Methodology}

\subsubsection{Systematic literature review and its conceptual boundaries}

A systematic literature review (SLR), based on the methodology of Tranfield, Denyer, and Smart (2003), supplies input to the categorization model. The conceptual boundaries of the SLR are marked out by how the key topics are conceptualized. Setting conceptual boundaries limits the logical range of technical terms (Lund, 2018), which is useful when search terms have multiple meanings (e.g., capabilities in our case). First, we conceptualize capability in a narrow sense as "a pattern of repetitive actions." This conceptualization is generalized from previous studies, such as the definition of "learned and stable pattern of collective activity" (Zollo \& Winter, 2002, p. 340) and "a set of current or potential activities" (Teece, 2014, p. 328). Second, we define EIFs as "organizations that are international from inception" (Svensson \& Payan, 2009, p. 410). Third, we conceptualize international performance as the benefits achieved from international markets or through internationalization (for a review of the international performance of EIFs, see Gerschewski and Xiao (2015)).

\subsubsection{Search strategy}

First, we used Science Direct, Scopus, and Web of Science as the most comprehensive journal databases. The subject areas chosen were 'international business,' 'entrepreneurship,' and 'general management.' We then used Boolean search terms in the title, abstract and keywords: capability AND ('born global' $O R$ 'international new venture' $O R$ 'global startup' $O R$ 'early internationalization' $O R$ 'international startup' $O R$ 'born international' $O R$ 'internalized $S M E$ ' $O R$ 'international entrepreneur' $O R$ 'early internationalizing firm'). Different spellings were used as well - for example, 'born-global' and 'BG' for 'born global,' 'global start-up' for 'global startup,' and 'early internationalisation' for 'early internationalization.' These synonymous terms exacerbate "the confusion associated with conducting literature reviews" (Svensson \& Payan, 2009, p. 409). Therefore, we use the term EIF, which synthesizes the time, context, and strategy frames (Svensson \& Payan, 2009). Since international performance covers a vast range of meanings, we did not use performance and its synonyms in the search terms, but in the exclusion criteria. Third, we set the period up to and including December 2018. We only 
targeted reviewed journal papers to ensure scientific rigor (Jones et al., 2011). This procedure resulted in 392 articles. See Figure 3.4 for the systematic literature search procedure and the results accruing at each stage.

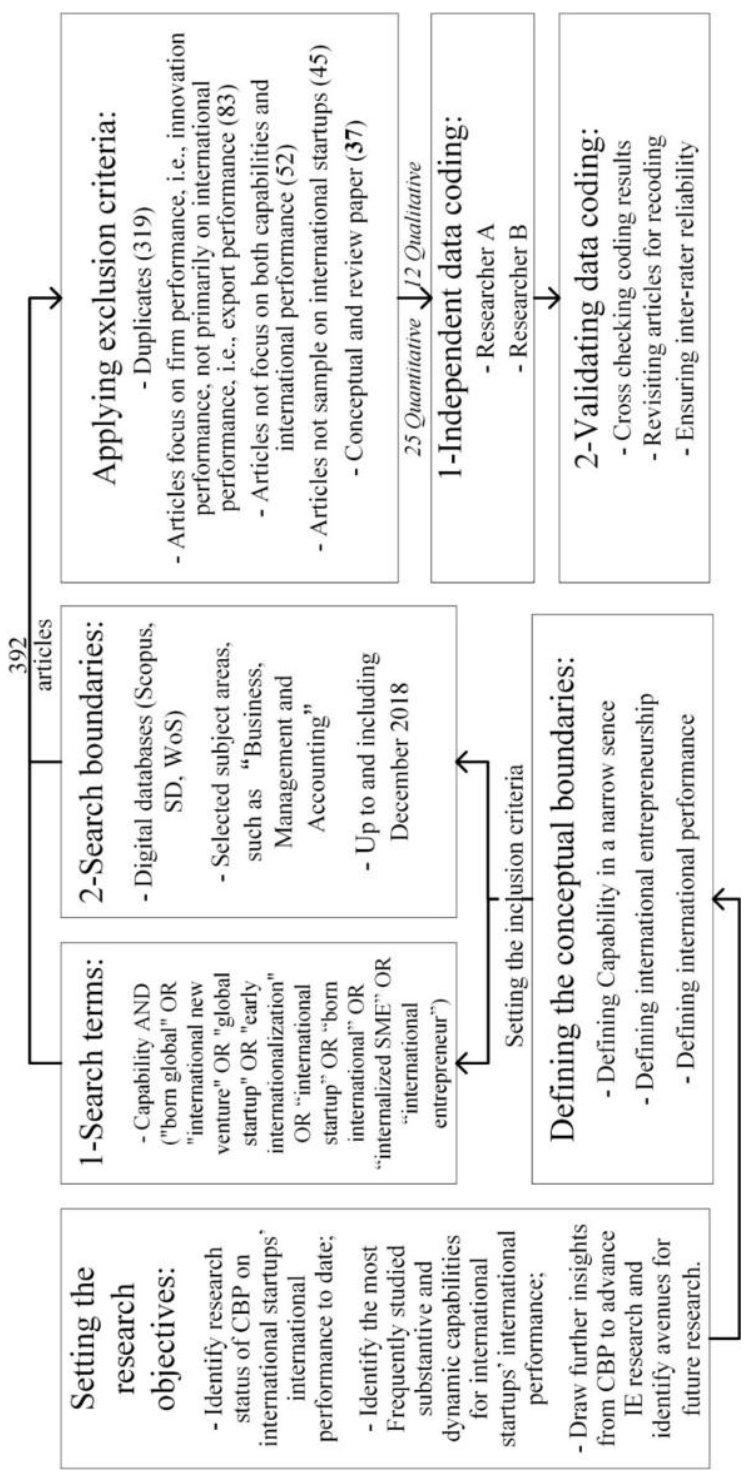

Figure 3.4. The procedure and result of the systematic literature search.

As exclusion criteria, we first discarded duplicate papers (319 articles were retained). Second, we assessed the quality of the remaining papers by checking whether the Chartered Association of Business Schools Academic Journal Guide 2015 (Cremer, Laing, Galliers, \& Kiem, 2015) listed the journal. This check 
resulted in 237 papers from high-quality journals. Third, we discarded papers that focused on general firm performance, and not on international performance. We found 83 papers that focused on the international performance of EIFs. Fourth, we excluded papers that did not focus on both capabilities and international performance and did not focus on EIFs. Two authors cross-checked the performance and capability criteria to ensure validity. After a final deletion of conceptual and review papers, we retained 37 papers in the paper pool (see Appendix).

\subsubsection{Analysis strategy}

To identify the most frequently studied SCs and DCs on the international performance of EIFs, and to ensure the validity of the analysis, two authors independently read and categorized each paper. The inter-coder reliability (Gaur \& Kumar, 2018) was 71 per cent. We resolved the remaining ambiguities through discussion. A detailed statement outlining the reasons for assigning a capability to a particular category is available in the Appendix 3.2.

First, we identified whether the paper's conceptualization of 'capability' followed the definition of capabilities as "a pattern of repetitive actions" (Zollo $\&$ Winter, 2002, p. 340). To make this assessment, we used the item formulation (quantitative papers) or illustrative quotations (qualitative papers). If there were strong cues of repetitive actions, such as "manage relationships with marketing channel members" (Boso et al., 2017, p. 15), the construct was categorized as a capability. We excluded papers that erroneously labelled the outcome of a capability as a capability itself. For instance, one paper defined social capabilities as "social interaction, relationship quality, and network ties" (Urban \& Sefalafala, 2015, p. 263).

We then judged whether a capability fell into the SC or DC category. Cues that address the use of resources to implement repetitive actions lead to a categorization of SC (Zahra et al., 2006). For instance, marketing capabilities that address "the integration processes designed to apply the firm's collective knowledge, skills and resources to the market-related needs of the business" (Ripolles et al., 2012, p. 281) are an example of marketing SCs. Cues that suggest topics such as creating, extending, or modifying the firm's resource base imply DCs (Helfat, 2007). An example of marketing capabilities that address the creation of a firm's resource base accords with the definition of marketing DCs 
that help firms to "learn about its market environment and use this knowledge to guide its actions" (Zhou et al., 2012, p. 26).

Should a definition contain cues of both SCs and DCs, we assigned the capability under the question to a 'mixed' group. For example, marketing capabilities that comprise actions of "understand changes taking place in its markets, together with those that enable to operate more effectively in the market place" (Martin \& Javalgi, 2016a, p. 2043) include both observations and operations and, therefore, belong to the mixed group.

In the third step, we judged the orientation (internal or external) of the capabilities. This was decided based on the locus of the transaction addressed by the capability. If the capability was oriented towards an outside transaction, such as "marketing channel members" (Boso et al., 2017, p. 15) or "external links and institutions" (Weerawardena et al., 2014, p. 239), we assigned it to the 'external' category. If the capability was oriented towards an environment that needed no outside transaction, such as internal "financial resources" (Gabrielsson, Sasi, \& Darling, 2004, p. 593) or the firm's "existing knowledge routines" (Weerawardena, Mort, \& Liesch, 2019, p. 5), we labelled it as an internally oriented capability.

In the fourth step, we judged whether the content of these actions referred to operation/administration or exploration/exploitation, respectively. For SCs, we judged as to whether they addressed an operational or administrative capability. Operational capabilities comprise activities relating to production or product support services, such as "productive activity" (Efrat \& Shoham, 2012, p. 678) or activities to "overcome resistance to "newness"" (Weerawardena et al., 2019, p. 5). Administrative capabilities comprise activities relating to coordination across internal functions, such as "deploy[ing] financial resources" (Gabrielsson et al., 2004, p. 593), or coordination with external networks, for example, to "establish subsidiaries rapidly and find suitable distributors" (Gabrielsson \& Gabrielsson, 2013, p. 1346).

For DCs, we judged whether they addressed exploratory or exploitative capabilities. Exploratory capabilities comprise activities related to creating new ideas and generating new resources. For example, international learning capability that acquires intelligence to address rapidly changing foreign markets represents a new idea and entails resource creation. Exploitative capabilities comprise activities related to modifying existing resources. For instance, DCs 
that "reconfigure a firm's resources and routines by environmental changes" (Pehrsson et al., 2015, p. 30) concern the modification of existing resources.

Finally, we judged whether those externally oriented capabilities targeted the international or the domestic market. Some definitions did not offer obvious cues. In these cases, we revisited other segments of the paper to check whether the author intended a domestic or international orientation.

\section{$3.4 \quad$ Results}

We identified 37 papers with 73 specific capabilities - those that researchers used directly in their studies. Twenty-three papers with 41 specific capabilities dealt with DCs. Thirteen papers with 13 specific capabilities concerned SCs. Twelve papers with 19 specific 'capabilities' were found not to address capabilities but rather capability antecedents or capability consequences. Table 3.1 reports the distribution and frequency of the specific capabilities that were studied. We find that some specific capabilities share similar performance implications. Hence, we used overarching capabilities - derived from the function of each generic type of capability (Figure 3.2 and Figure 3.3) - to cluster them (see Table 3.1).

\subsubsection{Research attention on SCs}

Researchers studied operational SCs more frequently than administrative SCs. SCs related to international market operations (quadrant (1) in Table 3.1) received the most attention. Substantive international marketing capabilities (Knight \& Cavusgil, 2004; Martin \& Javalgi, 2016a; Weerawardena et al., 2019) are the overarching capabilities identified in this category. Such capabilities contribute to the international performance of EIFs by facilitating their marketing-strategy executions (Zhang et al., 2009). The performance effect of substantive international marketing capabilities may also be mediated by, for example, positional advantage (Martin et al., 2017), or generating competitive business strategies (Knight \& Cavusgil, 2004). Conclusions from these mediation studies are consistent with Eisenhardt and Martin (2000), and Glavas et al. (2017) in that capabilities do not influence firm performance directly.

For SCs related to international market administration (quadrant (3)) received the second most attention. This type of capability comprises SCs that relate to 
effective administrative activities. International network management capabilities (Bai, Holmström-Lind, \& Johanson, 2018; Boso et al., 2017; Gabrielsson \& Gabrielsson, 2013) are typical overarching capabilities. Specifically, a marketing channel management capability supports the regional expansion of EIFs by strengthening the positive relationship between productinnovation novelty, risk-taking, competitiveness, aggressiveness, autonomy and regional expansion (Boso et al., 2017). International networking capabilities (Bai et al., 2018) help to establish international subsidiaries and distributors speedily (Gabrielsson \& Gabrielsson, 2013).

Concerning SCs related to internal administration (quadrant (6)) comprises SCs that maintain and increase administrative efficiency. The overarching capability identified in this category is internal management capabilities (Efrat \& Shoham, 2012; Gabrielsson et al., 2004). Specifically, finance capabilities facilitate the deployment of financial resources (Gabrielsson et al., 2004). Meanwhile, higher management capabilities benefit EIFs with a higher technological orientation, making them more proactive in exploiting opportunities and contributing to the independence and long-term survival of EIFs (Efrat \& Shoham, 2012). 
Table 3.1 Capability categories and the distribution.

\begin{tabular}{|c|c|c|c|c|}
\hline & Substantive capabilities (SCs) & & & \\
\hline \multirow[t]{2}{*}{$\begin{array}{l}\text { [Overarching } \\
\text { capabilities] } \\
\text { Specific } \\
\text { capabilities } \\
\text { (Art. No.) }\end{array}$} & $\begin{array}{l}\text { [Substantive marketing capabilities] } \\
\text { International marketing orientation (2); } \\
\text { International customer-support } \\
\text { capability (10); } \\
\text { Marketing planning and } \\
\text { implementation capability (14); } \\
\text { Marketing capabilities (15); } \\
\text { Marketing capabilities* (26); } \\
\text { Service capabilities (36); } \\
\text { International/Global marketing (37) }\end{array}$ & $\begin{array}{l}\text { (3)International market } \\
\text { administration } \\
\text { [International network } \\
\text { management capabilities] } \\
\text { Networking capability (17); } \\
\text { International marketing } \\
\text { channel management } \\
\text { capability (27); } \\
\text { International network } \\
\text { capability (32) }\end{array}$ & Internet capabilities (29) & $\begin{array}{l}\text { [Internal management } \\
\text { capabilities] } \\
\text { Finance capabilities (1); } \\
\text { Management capabilities } \\
\text { (13) }\end{array}$ \\
\hline & Dynamic capabilities (DCs) & & & \\
\hline $\begin{array}{l}\text { Category } \\
\text { [Overarching } \\
\text { capabilities] } \\
\text { Specific } \\
\text { capabilities } \\
\text { (Art. No.) }\end{array}$ & $\begin{array}{l}\text { (7)International market observation \& } \\
\text { evaluation } \\
\text { [Explorative entrepreneurial } \\
\text { capabilities] } \\
\text { International entrepreneurial orientation } \\
\text { (2); } \\
\text { Entrepreneurial capabilities (7); } \\
\text { International entrepreneurial capability } \\
\text { (8); } \\
\text { International entrepreneurial capability } \\
\text { (31) } \\
\text { [Explorative marketing capabilities] } \\
\text { Marketing capabilities (9); } \\
\text { Marketing capabilities (16); } \\
\text { Marketing capabilities* (26) }\end{array}$ & $\begin{array}{l}\text { 9) International market } \\
\text { resource acquisition } \\
\text { [Exploitative networking } \\
\text { capabilities] } \\
\text { Dynamic networking } \\
\text { capability (3); } \\
\text { Network development (35); } \\
\text { Network learning capability } \\
\text { (37) } \\
\text { [Exploitative } \\
\text { entrepreneurial capabilities] } \\
\text { Entrepreneurial capabilities } \\
\text { (7); } \\
\text { International entrepreneurial } \\
\text { capability (8); }\end{array}$ & $\begin{array}{l}\text { (11)Resource renewal } \\
\text { [Explorative learning } \\
\text { capabilities] } \\
\text { Capability of strategic } \\
\text { ambidexterity (6); } \\
\text { Internally focused learning } \\
\text { capability (20); } \\
\text { Network learning capability } \\
\text { (20); } \\
\text { Market-focused learning } \\
\text { capability (20); } \\
\text { Networking capability (33); } \\
\text { Internally focused learning } \\
\text { capability (37) }\end{array}$ & $\begin{array}{l}\text { 12) Resource reconfiguration } \\
\text { [Exploitative technical } \\
\text { capabilities] } \\
\text { Information technology } \\
\text { capability (5); } \\
\text { Innovation abilities (12); } \\
\text { R\&D/technology } \\
\text { capabilities (13); } \\
\text { IT capability (18) } \\
\text { [Resource exploiting } \\
\text { capabilities] } \\
\text { Capability of strategic } \\
\text { ambidexterity (6); } \\
\text { Dynamic capability (13); }\end{array}$ \\
\hline
\end{tabular}




\section{[Explorative market learning} capabilities]

Absorptive capacity (23);

International learning efforts (24);

Experiential learning (28);

Relationship-based knowledge

development (37);

International market focused learning capability (37)

Antecedents or outcomes of capabilities, but not capabilities by themselves
Experiential learning (28); International entrepreneurial Niche market development (35);

International market

(customers and competitors)

knowledge development (37) capability (31);
[Explorative technical capabilities]

Technology and

technological capabilities

(22);

Product development (35);

Transforming \& renewing

capabilities (35)
Marketing capability (20); Dynamic capability (21);

Marketing capabilities (30);

Dynamic capabilities (37);

Marketing capability (37)

\begin{tabular}{ll}
\hline $\begin{array}{l}\text { Specific } \\
\text { capabilities }\end{array}$ & $\begin{array}{l}\text { Unique resources and capabilities (4); Knowledge capability upgrading (11); Network capability upgrading (11); Managerial abilities } \\
\text { (Art. No.) }\end{array}$ \\
& $\begin{array}{l}\text { Marketing \& management-related capabilities (17);Technological capability (17); International learning effort (19); Human capabilities } \\
\text { (22); Social capabilities (22); Innovation capabilities (25); Marketing capabilities (25); Learning orientation (34); Entrepreneurial } \\
\text { initiatives (35); Stable leadership \& experience of top management (35);Technology and innovation and new product development (37) }\end{array}$ \\
\hline Notes: & 1. The distribution of specific capabilities are not mutually exclusive; \\
& 2. Number in brackets refers to the corresponding paper in the Appendix; \\
& 3." means Mixed category of SCs and DCs; \\
& 5. No study discusses domestic market-oriented capabilities therefore we did not report the result.
\end{tabular}


In the case of SCs related to internal operations (quadrant (5)) received the least research attention. They help to sustain the efficiency of the firm's operational activities. Only one specific capability was found in this category: IT capabilities (Glavas et al., 2017). IT capabilities that focus on turning knowledge embedded in their Internet-based networks into customer value promote the international performance of EIFs (Glavas et al., 2017).

\subsubsection{Research attention on DCs}

The most frequently studied DCs are related to international market observation and evaluation - quadrant (7). These capabilities address the monitoring of international markets, and the identifying and evaluating of new opportunities. We identified three typical overarching capabilities in this category; they were explorative entrepreneurial capabilities (Knight \& Cavusgil, 2004; Zhang, Gao, \& Cho, 2017; Zhang et al., 2009), explorative market learning capabilities (De Clercq, Zhou, \& Wu, 2016; Weerawardena et al., 2019; Wu \& Voss, 2015), and explorative marketing capabilities (Blesa, Ripollés, \& Monferrer, 2010; Martin \& Javalgi, 2016a; Zhou et al., 2012).

Specifically, explorative entrepreneurial capabilities contribute to the international performance of EIFs by acting on identified opportunities or creating new opportunities in international markets (Karra, Phillips, \& Tracey, 2008) through identification and acquisition. Such capabilities facilitate EIFs in identifying and acquiring necessary resources, including entrepreneurial and management knowledge (Knight \& Cavusgil, 2004) and innovative networking and marketing strategies (Zhang et al., 2017). Explorative market learning capabilities contribute to the international performance of EIFs through tracking international market changes (Zhang et al., 2009), acquiring international market knowledge and identifying customers' needs (Weerawardena et al., 2019), and increasing the match between existing competencies in foreign market opportunities (De Clercq et al., 2016). Explorative marketing capabilities stimulate the international performance of EIFs by addressing rapidly changing markets (Zhou et al., 2012), and identifying and selecting the appropriate intended value propositions for targeting customers (Martin \& Javalgi, 2016a).

The second most frequently studied DCs are related to internal resource reconfigurations - quadrant (12). These DCs involve instigating and implementing new change initiatives concerning the reconfiguration of internal 
resources. Two overarching capabilities fall into this category: resource exploiting capabilities (Gabrielsson \& Gabrielsson, 2013; Pehrsson et al., 2015; Weerawardena et al., 2019) and exploitative technical capabilities (Efrat \& Shoham, 2012; Zhang \& Tansuhaj, 2007).

Resource exploiting capabilities contribute to the international performance of EIFs mainly through resource reconfigurations. For example, Gabrielsson and Gabrielsson (2013), Pehrsson et al. (2015), and Weerawardena et al. (2019) show that DCs aimed at reconfiguring resources and building new routines that respond to environmental changes enhance the international performance of EIFs. This finding is supported by Weerawardena et al. (2014) who found that the firm's internal learning capability that focuses on "build, integrate, and reconfigure technical and social (non-technical) knowledge generated through internal sources" (p. 226) positively influences the early internationalization of EIFs through the moderating influence of innovation. As to the exploitative technical capabilities, there are several ways in which they impact the international performance of EIFs. For example, information technology capability enables EIFs to have advanced IT architectures and human resources, which facilitates solving problems of greater efficiency (Zhang \& Tansuhaj, 2007). Also, technology/R\&D capabilities assist the international performance of EIFs by developing high value-added products and coordinating experience inside the firm (Efrat \& Shoham, 2012).

DCs that relate to resource acquisition in international markets and DCs that relate to resource renewal received the same amount of research attention. For DCs on international market resource acquisition (quadrant (9), exploitative networking capabilities (Khan \& Lew, 2018; Mort \& Weerawardena, 2006; Weerawardena et al., 2019) and exploitative entrepreneurial capabilities (Karra et al., 2008; Zhang et al., 2009) are the two representative overarching capabilities.

Exploitative networking capabilities contribute to the international performance of EIFs in three ways. First, the international networking activities of EIFs facilitate the identification of new opportunities in the global market (Mort \& Weerawardena, 2006). Second, international networking capability helps EIFs to obtain the necessary resources through alliance creation and social embeddedness (Zhang et al., 2009). Third, they help to access valuable information and resources within the networks and to develop an effective marketing strategy for sound performance in foreign markets (Falahat, Knight, 
\& Alon, 2018). Exploitative entrepreneurial capabilities promote the international performance of EIFs in two ways. First, entrepreneurial capabilities help EIFs to develop international operations (Karra et al., 2008) and establish initial criteria for decision making (Bunz, Casulli, Jones, \& Bausch, 2017), decreasing their liability of newness and increasing their ability to deal with complexities (Karra et al., 2008). Second, entrepreneurial capabilities help EIFs to acquire international market knowledge and information on emerging customer needs via their networks, helping them to identify new international market opportunities (Khan \& Lew, 2018; Weerawardena et al., 2019).

DCs that relate to resource renewal (quadrant (11)) comprise capabilities that integrate new resources into the original ones, as well as those effective resource configurations that stimulate the launch of latent and dispersed knowledge, and new products and services (Madsen, 2010). Explorative learning capabilities (Weerawardena et al., 2019; Weerawardena et al., 2014) and explorative technical capabilities (Khan \& Lew, 2018; Urban \& Sefalafala, 2015) are the two overarching capabilities identified in this category.

Explorative learning capabilities mostly focus on generating new knowledge and ideas from the processes or the consequences of networking and marketing activities, such as learning from networks (Weerawardena et al., 2014), learning from markets, and internally focused learning (Weerawardena et al., 2019). Therefore, the explorative learning capabilities are different from the explorative market learning capabilities (whose functions are principally to extend the international market-related resource bases of EIFs). Explorative technical capabilities contribute to the international performance of EIFs mainly by gathering new technological knowledge and creating new products (Khan \& Lew, 2018; Urban \& Sefalafala, 2015). For example, technology and technological capabilities help to increase EIFs' technological distinctiveness and stimulate their technology acquisition (Urban \& Sefalafala, 2015). Product development activities increase EIFs' product knowledge in a specific domain (Khan \& Lew, 2018). With transforming and renewing capabilities, EIFs can convert the accumulated product knowledge into new products that satisfy emerging customer needs (Khan \& Lew, 2018). 


\subsection{Discussion and future research agenda}

This study established the types of capabilities related to the international performance of EIFs that have been subject to academic research. To address the ambiguity stemming from the proliferation of capability terminology, we introduced a capability categorization model to classify SCs and DCs based on the type of performance that they impact. We then used the capability categorization model to identify the capabilities that received the most research attention and those capabilities that have been overlooked.

We now discuss our findings of how the paper informs relevant literature (Shepherd \& Wiklund, 2019). First, this study contributes to solving the ambiguity problem arising from the proliferation of capability terminology by proposing a capability categorization model. A large and heterogeneous set of capabilities has been analyzed in the study of IE (Boso et al., 2017; Efrat \& Shoham, 2012; Martin \& Javalgi, 2016b) since the seminal paper of McDougall and Oviatt (2003). However, some capabilities with different meanings have been used interchangeably, while some capabilities with the same meaning have been termed differently. This confusion over terminology hinders the development of theory and causes confusion for research efforts going forward. Our capability categorization model distinguishes capabilities according to their performance implications. Accordingly, our study provides a framework for future studies on terming capabilities, for example, the basic terminology of SCs and DCs (Helfat \& Winter, 2011) and other specific capabilities. It goes beyond the study of IE: researchers can apply it to other fields, such as strategic management and general entrepreneurship research.

Second, we inform the literature on CBP by pointing out the capabilities that have been overlooked in current studies on capabilities and the international performance of EIFs. Studies on the relationship between capabilities in the domestic market and international performance would appear to be lacking (see Table 3.1). Ignoring domestic market capabilities is problematic. First, capabilities oriented towards the domestic market benefit EIFs by improving technical efficiency and evolution fitness in domestic markets. For example, developing and maintaining alliances in the domestic market (domestic market networking capabilities) increase the efficiency of the resource acquisition process of EIFs, leading to a relative advantage on reducing costs (Kondo, 2005). Second, international business studies - but not IE research thus far - has highlighted the performance implications of domestic market-oriented 
capabilities on international performance (Cuervo-Cazurra, Ciravegna, Melgarejo, \& Lopez, 2018; Nadkarni \& Perez, 2007; Sigfusson \& Harris, 2013). For example, prior studies have shown that multinational enterprises from emerging economies tend to nurture their capability in the domestic market to create a base for subsequent internationalization (Li Sun, 2009).

Third, we inform the literature on IE by assessing the state-of-the-art on the interface of capabilities and the international performance of EIFs. Specifically, we identified and categorized capabilities that have been studied from the perspective of the international performance of EIFs. To the best of our knowledge, our study is among the first to do so. Our research, to some extent, overlaps with existing IE review studies - for example, Dzikowski (2018); Keupp and Gassmann (2009); Romanello and Chiarvesio (2019). However, none of these review studies focuses specifically on the interface of capabilities and the international performance of EIFs. Therefore, our study provides IE scholars with insights into the frequency of capabilities that have been studied. Future IE studies on relevant topics could take our study as a guideline to undertake quantitative meta-analysis. Additionally, future studies could use our results to seek out research gaps, for example, in the capabilities that have been overlooked or rarely studied.

\subsubsection{Managerial relevance}

This paper's lessons for management are three-fold. First, EIF managers could use our capability categorization models to facilitate their capability development so that they are better placed to pursue success in international markets. Our model provides managers with the capabilities needed for firms to achieve high international performance. Accordingly, managers could develop the necessary capabilities on their own or access them from external sources. Second, EIF managers should not consider these capabilities alone but build a combination of capabilities for their firm's success. Our paper highlights various dimensions concerning the implications of capabilities for international performance (e.g., internal/external or explorative/exploitative). We recommend that managers do not restrict themselves to only one type of capability but construct a capability portfolio with several capabilities when developing their business. It is important to appreciate that factors from various dimensions influence EIF performance (Gerschewski, Rose, \& Lindsay, 2015), and none of 
those capabilities mentioned previously contribute to firm performance on its own. Third, EIF managers could learn from our results by referring to corresponding studies on how to develop specific capabilities. Capabilities have been criticized as being tautological, vague, and impractical (Eisenhardt \& Martin, 2000). Our fine-grained capability categorization models tabulate studies that have relevance in specific circumstances and itemize actions that are feasible with different capabilities. Therefore, managers can use our results as a reference point for identifying studies that are the most workable in terms of capability development.

\subsubsection{Future research agenda}

We now relate our findings to the major knowledge gaps that demonstrate where future research on the capability-international performance interface should direct its attention. We suggest four streams for future study: (1) researching the relationship between capability portfolios of different types of capabilities and the international performance of EIFs; (2) studying the interactions between SCs and the corresponding DCs for the international performance of EIFs; (3) carefully measuring capabilities; (4) expanding research on the influence of domestic market-oriented SCs and DCs.

First, we suggest that future studies explore the interplay among different types of capabilities - for example, marketing capabilities and the international performance of EIFs. We found that researchers often analyzed SCs and DCs in isolation. However, there may be compensating, enhancing, and suppressing effects among interdependent capabilities (Black \& Boal, 1994; Jie \& Harms, 2019). For instance, research suggests that it is capability portfolios rather than independent capabilities that promote offers from firms (Sjödin, Parida, and Kohtamäki (2016). Also, a combination of entrepreneurial capabilities lowers EIFs' liability of newness and helps to manage the complexity and uncertainty in international markets (Karra et al., 2008). Future studies could analyze how capability portfolios contribute to the international performance of EIFs. For example, capability portfolios that comprise various types of capabilities that address different functions including marketing, networking, and technological functions could well hold out the promise of a more comprehensive understanding of the international performance of EIFs. 
Second, future studies could test the interactions between SCs and corresponding DCs empirically. Currently, qualitative studies and conceptual research address the SC-DC (of the same type) interactions (Weerawardena et al., 2019), but there appears to be no quantitative studies on this topic in IE. Future studies could, for example, empirically test dynamic bundles as proposed by Peteraf, Di Stefano, and Verona (2013). Dynamic bundles represent complementary conjunctions of SCs and DCs to achieve a sustainable advantage (Waleczek, von den Driesch, Flatten, \& Brettel, 2019). For instance, a dynamic bundle of marketing capabilities consists of substantive and corresponding dynamic marketing capabilities. Knowing the interaction between SCs and their dynamic counterparts contributes to a more in-depth understanding of how capabilities work and, therefore, provides insights into managerial and entrepreneurial practice. As Peteraf et al. (2013, p. 1407) have pointed out: "really understanding dynamic capabilities requires seeing the complete picture and exploring interlinked dynamic bundles as a whole" (p. 1407).

Third, the review shows that the operationalization of capabilities remains an issue. Table 3.1 demonstrates that twelve papers that purport to measure capability defined as repetitive actions - use items that suggest either antecedents or consequences or a mix thereof (Arend \& Bromiley, 2009; Pavlou \& El Sawy, 2011). Examples of 'antecedent' measures of capabilities include studies that base their measure on commitment (Khalid \& Larimo, 2012) or orientation (Gerschewski, Lew, Khan, \& Park, 2018) about organizational activities. Examples of 'consequence' measures of capabilities include studies that base their measure on items that evaluate the firm's related resources advantages over its competitors (Efrat \& Shoham, 2012). Other measurement instruments do not measure what they claim to measure. For example, some studies do not label their construct as a capability but they measure it as one, nonetheless (De Clercq et al., 2016; Knight \& Cavusgil, 2004). These divergent capability measures demonstrate the fragmented nature of current understanding (Helfat \& Winter, 2011). As a consequence, it is not only challenging to integrate the empirical knowledge gathered from these studies (Madsen, 2013) but also to extract actionable implications for practice in management and entrepreneurship (Pavlou \& El Sawy, 2011). Additionally, researchers hold that theory development need a strong link between constructs and their empirical measures (Laaksonen \& Peltoniemi, 2018; Venkatraman \& Camillus, 1984). Therefore, 
we encourage future research to build scales that have a wide validity in measuring capabilities.

Finally, initial and subsequent internationalization relies on capabilities that have their origin in capabilities that companies developed initially for the domestic market (Sigfusson \& Harris, 2013). Furthermore, domestic market operations either support the international market behaviors of EIFs by providing experience to deal with the challenges of international markets, or they hinder their performance through inertia (Nadkarni, Herrmann, \& Perez, 2011). Some domestic capabilities may be particularly relevant. For instance, EIFs increase their personal relationship strength and are more active in developing new relationships in foreign markets when they have a large domestic market (Sigfusson \& Harris, 2013). What is more, firms with capabilities that deal with the political risks in home markets perform better in dealing with the challenges of international markets, which in turn contribute to the international performance of firms (Cuervo-Cazurra et al., 2018). Therefore, we argue that capabilities aimed at the domestic market also matter for the international performance of EIFs. Potential research questions flow from these considerations: Do the domestic market-oriented capabilities of EIFs influence their international performance and, if so, how? What is the impact of the domestic market-oriented capabilities of EIFs on their international marketoriented capabilities, and how does this influence their international performance?

\subsection{Conclusion}

Our study has two main limitations. First, we only include published peerreviewed papers and exclude book chapters or conference papers. Hence, our selection may be subject to the publication bias of systematic literature reviews (Egger, Dickersin, \& Smith, 2001). Publication bias describes the situation where "studies with statistically significant results are more likely to get published than those with non-significant results" (Egger et al., 2001, p. 52). Therefore, caution should be exercised when generalizing our results. Second, we only reported those capabilities that have been most frequently studied. However, the capabilities that have been the most frequently studied are not necessarily most strongly liked to performance. Understanding the most critical capabilities for the international performance of EIFs needs quantitative metaanalysis on capabilities from each category. As our finer-grained models point 
out, capabilities in each category address different functions and carry diverse implications for international performance. However, conducting additional meta-analysis is beyond the scope of this study.

Research on the performance implications of capabilities for EIFs is especially pertinent, given the huge impact that these firms have for the economy. We show that the CBP is a fruitful theoretical lens, and we provide categorizations and suggestions for its improved use. We also elaborate paths that may reveal how future research can add to research on international performance studying capability portfolios and carefully measuring capabilities. Future efforts to broaden the scope of this work on EIF capabilities should energize both the practitioner and the research community. 


\section{References}

Al-Aali, A., \& Teece, D. J. (2014). International Entrepreneurship and the Theory of the (Long-Lived) International Firm: A Capabilities Perspective. Entrepreneurship Theory and Practice, 38(1), 95-116. doi:10.1111/etap.12077

Arend, R. J., \& Bromiley, P. (2009). Assessing the dynamic capabilities view: Spare change, everyone? Strategic Organization, 7(1), 75-90. doi:https://doi.org/10.1177/1476127008100132

Bai, W., Holmström-Lind, C., \& Johanson, M. (2018). Leveraging networks, capabilities and opportunities for international success: A study on returnee entrepreneurial ventures. Scandinavian Journal of Management, 34(1), 51-62. doi:https://doi.org/10.1016/j.scaman.2017.12.001

Baum, J. A. C., Li, S. X., \& Usher, J. M. (2000). Making the next move: How experiential and vicarious learning shape the locations of chains' acquisitions. Administrative Science Quarterly, 45(4), 766-801. doi:10.2307/2667019

Benner, M. J., \& Tushman, M. L. (2003). Exploitation, exploration, and process management: The productivity dilemma revisited. Academy of Management Review, 28(2), 238-256. doi:10.5465/amr.2003.9416096

Black, J. A., \& Boal, K. B. (1994). Strategic resources: Traits, configurations and paths to sustainable competitive advantage. Strategic Management Journal, 15(S2), 131-148. doi:https://doi.org/10.1002/smj.4250151009

Blesa, A., Ripollés, M., \& Monferrer, D. (2010). Marketing capabilities: Do they matter in INVs? World Review of Entrepreneurship, Management and Sustainable Development, 6(1-2), 71-99. doi:10.1504/wremsd.2010.031639

Boso, N., Oghazi, P., \& Hultman, M. (2017). International entrepreneurial orientation and regional expansion. Entrepreneurship and Regional Development, 29(12SI), 4-26. doi:10.1080/08985626.2016.1255430

Bunz, T., Casulli, L., Jones, M. V., \& Bausch, A. (2017). The dynamics of experiential learning: Microprocesses and adaptation in a professional service INV. International Business 26riew, 26(2), doi:10.1016/j.ibusrev.2016.07.001

Collis, D. J. (1996). Organizational capability as a source of profit. In B. Moingeon \& A. Edmondson (Eds.), Organizational Learning and Competitive Advantage (pp. 139-163). London: SAGE Publications.

Coviello, N., \& Munro, H. (1995). Growing the entrepreneurial firm: Networking for international market development. European Journal of Marketing, 29(7), 4961. doi:10.1108/03090569510095008

Cremer, R. D., Laing, A., Galliers, B., \& Kiem, A. (2015). ABS Academic Journal Guide 2015. Retrieved from London: https://charteredabs.org/academic-journalguide-2015/\% 2017-10-10 14:07:00 
Crossan, M. M., \& Apaydin, M. (2010). A multi-dimensional framework of organizational innovation: A systematic review of the literature. Journal of Management Studies, 47(6), 1154-1191. doi:https://doi.org/10.1111/j.14676486.2009.00880.x

Cuervo-Cazurra, A., Ciravegna, L., Melgarejo, M., \& Lopez, L. (2018). Home country uncertainty and the internationalization-performance relationship: Building an uncertainty management capability. Journal of World Business, 53(2), 209-221. doi:https://doi.org/10.1016/j.jwb.2017.11.002

De Clercq, D., Zhou, L., \& Wu, A. (2016). Unpacking the relationship between young ventures' international learning effort and performance in the context of an emerging economy. International Entrepreneurship and Management Journal, 12(1), 47-66. doi:10.1007/s11365-014-0328-1

Dimitratos, P., Lioukas, S., \& Carter, S. (2004). The relationship between entrepreneurship and international performance: The importance of domestic environment. International Business Review, 13(1), 19-41. doi:https://doi.org/10.1016/j.ibusrev.2003.08.001

Dzikowski, P. (2018). A bibliometric analysis of born global firms. Journal of Business Research, 85, 281-294. doi:10.1016/j.jbusres.2017.12.054

Efrat, K., \& Shoham, A. (2012). Born global firms: The differences between their shortand long-term performance drivers. Journal of World Business, 47(4), 675-685. doi:10.1016/j.jwb.2012.01.015

Egger, M., Dickersin, K., \& Smith, G. D. (2001). Problems and limitations in conducting systematic reviews. In M. Egger, G. D. Smith, \& D. G. Altman (Eds.), Systematic Reviews in Health Care: Meta-Analysis in Context (Second ed., pp. 43-68): BMJ Publishing Group.

Eisenhardt, K. M., \& Martin, J. A. (2000). Dynamic capabilities: What are they? Strategic Management Journal, 21(10 - 11), 1105-1121. doi:https://doi.org/10.1002/1097-0266(200010/11)21:10/11<1105::AIDSMJ133>3.0.CO;2-E

Eurofound. (2012). Born global: The potential of job creation in new international businesses. Retrieved from Luxembourg: https://www.eurofound.europa.eu/publications/report/2013/labour-marketbusiness/born-global-the-potential-of-job-creation-in-new-internationalbusinesses

Falahat, M., Knight, G., \& Alon, I. (2018). Orientations and capabilities of born global firms from emerging markets. International Marketing Review, 35(6), 936-957. doi:10.1108/IMR-01-2017-0021

Fertik, M. (2013). Go international, young startup. Retrieved from https://hbr.org/2013/01/go-international-young-startup 
Gabrielsson, M., Sasi, V., \& Darling, J. (2004). Finance strategies of rapidly-growing Finnish SMEs: Born internationals and born globals. European Business Review, 16(6), 590-604. doi:10.1108/09555340410565413

Gabrielsson, P., \& Gabrielsson, M. (2013). A dynamic model of growth phases and survival in international business-to-business new ventures: The moderating effect of decision-making logic. Industrial Marketing Management, 42(8), 1357-1373. doi:10.1016/j.indmarman.2013.07.011

Gaur, A., \& Kumar, M. (2018). A systematic approach to conducting review studies: An assessment of content analysis in 25years of IB research. Journal of World Business, 53(2), 280-289. doi:https://doi.org/10.1016/j.jwb.2017.11.003

Gerschewski, S., Lew, Y. K., Khan, Z., \& Park, B. I. (2018). Post-entry performance of international new ventures: The mediating role of learning orientation. International Small Business Journal, 36(7), 807-828. doi:10.1177/0266242618790321

Gerschewski, S., Rose, E. L., \& Lindsay, V. J. (2015). Understanding the drivers of international performance for born global firms: An integrated perspective. Journal of World Business, 50(3), 558-575. doi:https://doi.org/10.1016/j.jwb.2014.09.001

Gerschewski, S., \& Xiao, S. S. (2015). Beyond financial indicators: An assessment of the measurement of performance for international new ventures. International Business Review, 24(4), 615-629. doi:https://doi.org/10.1016/j.ibusrev.2014.11.003

Glavas, C., Mathews, S., \& Bianchi, C. (2017). International opportunity recognition as a critical component for leveraging internet capabilities and international market performance. Journal of International Entrepreneurship, 15(1), 1-35. doi:10.1007/s10843-016-0191-y

Grant, R. M. (2016). Contemporary strategy analysis: Text and cases edition: John Wiley \& Sons.

Han, M. (2006). Developing social capital to achieve superior internationalization: A conceptual model. Journal of International Entrepreneurship, 4(2), 99-112. doi:10.1007/s10843-007-0003-5

Helfat, C. E. (2007). Dynamic capabilities: Foundations. In C. E. Helfat, S. Finkelstein, W. Mitchell, M. Peteraf, H. Singh, D. Teece, \& S. G. Winter (Eds.), Dynamic Capabilities: Understanding Strategic Change in Organizations (pp. 1-18). London: Blackwell Publishing Ltd.

Helfat, C. E., \& Peteraf, M. A. (2003). The dynamic resource-based view: Capability lifecycles. Strategic Management Journal, 24(10), 997-1010. doi:https://doi.org/10.1002/smj.332

Helfat, C. E., \& Winter, S. G. (2011). Untangling dynamic and operational capabilities: Strategy for the (n)ever-changing world. Strategic Management Journal, 32(11), 1243-1250. doi:https://doi.org/10.1002/smj.955 
Jantunen, A., Puumalainen, K., Saarenketo, S., \& Kyläheiko, K. (2005). Entrepreneurial orientation, dynamic capabilities and international performance. Journal of International Entrepreneurship, 3(3), 223-243. doi:10.1007/s10843-005-11332

Jie, S., \& Harms, R. (2019, 2019/08/01). Dynamic bundle of capabilities and firm's international performance: A configurational analysis. Paper presented at the Academy of Management Proceedings, Boston.

Jones, M. V., Coviello, N., \& Tang, Y. K. (2011). International entrepreneurship research (1989-2009): A domain ontology and thematic analysis. Journal of Business Venturing, 26(6), 632-659. doi:https://doi.org/10.1016/j.jbusvent.2011.04.001

Karafyllia, M., \& Zucchella, A. (2017). Synergies and tensions between and within domestic and international market activities of firms. International Business Review, 26(5), 942-958. doi:https://doi.org/10.1016/j.ibusrev.2017.03.003

Karra, N., Phillips, N., \& Tracey, P. (2008). Building the born global firm: Developing entrepreneurial capabilities for international new venture success. Long Range Planning, 41(4), 440-458. doi:https://doi.org/10.1016/j.lrp.2008.05.002

Keupp, M. M., \& Gassmann, O. (2009). The past and the future of international entrepreneurship: a review and suggestions for developing the field. Journal of Management, 35(3), 600-633.

Khalid, S., \& Larimo, J. (2012). Firm specific advantage in developed markets: Dynamic capability perspective. Management International Review, 52(2), 233-250. doi:10.1007/s11575-012-0137-0

Khan, Z., \& Lew, Y. K. (2018). Post-entry survival of developing economy international new ventures: A dynamic capability perspective. International Business Review, 27(1), 149-160. doi:10.1016/j.ibusrev.2017.06.001

Knight, G., \& Cavusgil, S. T. (1996). The born global firm: A challenge to traditional internationalization theory. In S. T. Cavusgil \& T. Madsen (Eds.), Advances in International Marketing (Vol. 8, pp. 11-26). Greenwich, CT: JAI Press.

Knight, G., \& Cavusgil, S. T. (2004). Innovation, organizational capabilities, and the born-global firm. Journal of International Business Studies, 35(2), 124-141. doi:10.1057/palgrave.jibs.8400071

Knight, G. A., \& Liesch, P. W. (2016). Internationalization: From incremental to born global. Journal of World Business, 51(1), 93-102. doi:https://doi.org/10.1016/j.jwb.2015.08.011

Kondo, M. (2005). Networking for technology acquisition and transfer. International Journal of Technology Management, 32(1-2), 154-175. doi:https://doi.org/10.1504/IJTM.2005.006822

Laaksonen, O., \& Peltoniemi, M. (2018). The essence of dynamic capabilities and their measurement. International Journal of Management Reviews, 20(2), 184-205. doi:https://doi.org/10.1111/ijmr.12122 
Li Sun, S. (2009). Internationalization strategy of MNEs from emerging economies: The case of Huawei. Multinational Business Review, 17(2), 129-156. doi:https://ssrn.com/abstract=1528265

Liu, X., Gao, L., Lu, J., \& Lioliou, E. (2016). Does learning at home and from abroad boost the foreign subsidiary performance of emerging economy multinational enterprises? International Business Review, 25(1), 141-151. doi:https://doi.org/10.1016/j.ibusrev.2014.10.012

Low, M. B., \& MacMillan, I. C. (1988). Entrepreneurship: Past research and future challenges. Journal of Management, 14(2), 139-161. doi:https://doi.org/10.1177/014920638801400202

Lund, M. D. (2018). Defining conceptual boundaries. In N. R. Hanson \& M. D. Lund (Eds.), Perception and Discovery: An Introduction to Scientific Inquiry (pp. 1527). Cham: Springer International Publishing.

Madsen, E. L. (2010). A dynamic capability framework - Generic types of dynamic capabilities and their relationship to entrepreneurship. In S. Wall, C. Zimmermann, R. Klingebiel, \& D. Lange (Eds.), Strategic Reconfigurations: Building Dynamic Capabilities in Rapid Innovation-based Industries (pp. 223242): Edward Elgar Publishing.

Madsen, T. K. (2013). Early and rapidly internationalizing ventures: Similarities and differences between classifications based on the original international new venture and born global literatures. Journal of International Entrepreneurship, 11(1), 65-79. doi:10.1007/s10843-012-0099-0

Manyika, J., Lund, S., Bughin, J., Woetzel, J., Stamenov, K., \& Dhingra, D. (2016). Digital globalization: The new era of global flows. Retrieved from https://www.mckinsey.com/ /media/McKinsey/Business\%20Functions/McKi nsey\%20Digital/Our\%20Insights/Digital\%20globalization\%20The\%20new\% 20era\%20of\%20global\%20flows/MGI-Digital-globalization-Full-report.ashx

Martin, S. L., \& Javalgi, R. G. (2016a). Entrepreneurial orientation, marketing capabilities and performance: The moderating role of competitive intensity on Latin American international new ventures. Journal of Business Research, 69(6), 2040-2051. doi:https://doi.org/10.1016/j.jbusres.2015.10.149

Martin, S. L., Javalgi, R. G., \& Cavusgil, E. (2017). Marketing capabilities, positional advantage, and performance of born global firms: Contingent effect of ambidextrous innovation. International Business Review, 26(3), 527-543. doi:https://doi.org/10.1016/j.ibusrev.2016.11.006

Martin, S. L., \& Javalgi, R. R. G. (2016b). Entrepreneurial orientation, marketing capabilities and performance: The moderating role of competitive Iintensity on Latin American international new ventures. Journal of Business Research, 69(6), 2040-2051. doi:https://doi.org/10.1016/j.jbusres.2015.10.149 
Mathews, S., Bianchi, C., Perks, K. J., Healy, M., \& Wickramasekera, R. (2016). Internet marketing capabilities and international market growth. International Business Review, 25(4), 820-830. doi:10.1016/j.ibusrev.2015.10.007

McDougall, P. P. (1989). International versus domestic entrepreneurship: New venture strategic behavior and industry structure. Journal of Business Venturing, 4(6), 387-400. doi:https://doi.org/10.1016/0883-9026(89)90009-8

Mets, T. (2014). How "born global" SMEs are born: Small emergent country cases. Paper presented at the 27th Annual SEAANZ Conference, Sydney. http://www.seaanz.org/sites/seaanz/documents/2014SEAANZConference/SE AANZ-2014-Mets.pdf\% 2017-11-24 16:49:00

Meyer, K. E., \& Xin, K. R. (2018). Managing talent in emerging economy multinationals: integrating strategic management and human resource management. The International Journal of Human Resource Management, 29(11), 1827-1855. doi:10.1080/09585192.2017.1336362

Mintzberg, H. (1980). Structure in 5's - A synthesis of the research on organization design. Management Science, 26(3), 322-341. doi:10.1287/mnsc.26.3.322

Mort, G. S., \& Weerawardena, J. (2006). Networking capability and international entrepreneurship: How networks function in Australian born global firms. International Marketing Review, 23(5), 549-572. doi:10.1108/02651330610703445

Nadkarni, S., Herrmann, P., \& Perez, P. D. (2011). Domestic mindsets and early international performance: The moderating effect of global industry conditions. Strategic Management Journal, 32(5), 510-531. doi:https://doi.org/10.1002/smj.888

Nadkarni, S., \& Perez, P. D. (2007). Prior conditions and early international commitment: The mediating role of domestic mindset. Journal of International Business Studies, 38(1), 160-176. doi:10.1057/palgrave.jibs.8400248

Nelson, R. R., \& Winter, S. G. (1982). The Schumpeterian tradeoff revisited. American economic review, 72(1), 114-132. doi:https://www.jstor.org/stable/1808579

Ojala, A., Evers, N., \& Rialp, A. (2018). Extending the international new venture phenomenon to digital platform providers: A longitudinal case study. Journal $\begin{array}{lll}\text { of } \quad \text { World } \quad \text { Business, } & \text { 725-739. }\end{array}$ doi:https://doi.org/10.1016/j.jwb.2018.05.001

Oviatt, B. M., \& McDougall, P. P. (1995). Global start-ups: Entrepreneurs on a worldwide stage. Academy of Management Perspectives, 9(2), 30-43. doi:https://doi.org/10.5465/ame.1995.9506273269

Pavlou, P. A., \& El Sawy, O. A. (2011). Understanding the elusive black box of dynamic capabilities. Decision $\quad$ Sciences, $239-273$. doi:https://doi.org/10.1111/j.1540-5915.2010.00287.X

Pehrsson, T., Ghannad, N., Pehrsson, A., Abt, T., Chen, S., Erath, F., \& Hammarstig, T. (2015). Dynamic capabilities and performance in foreign markets: 
Developments within international new ventures. Journal of International Entrepreneurship, 13(1), 28-48. doi:10.1007/s10843-014-0139-z

Peteraf, M., Di Stefano, G., \& Verona, G. (2013). The Elephant in the Room of Dynamic Capabilities: Bringing Two Diverging Conversations Together. Strategic Management Journal, 34(12), 1389-1410. doi:10.1002/smj.2078

Prange, C., \& Verdier, S. (2011). Dynamic capabilities, internationalization processes and performance. Journal of World Business, 46(1), 126-133. doi:https://doi.org/10.1016/j.jwb.2010.05.024

Priem, R. L., Butler, J. E., \& Li, S. (2013). Toward reimagining strategy research: Retrospection and prospection on the 2011 AMR decade award article. Academy of Management Review, 38(4), 471-489. doi:https://doi.org/10.5465/amr.2013.0097

Reuber, A. R., Dimitratos, P., \& Kuivalainen, O. (2017). Beyond categorization: New directions for theory development about entrepreneurial internationalization. Journal of International Business Studies, 48(4), 12. doi:10.1057/s41267-0170070-3

Rialp, A., Rialp, J., \& Knight, G. (2005). The phenomenon of early internationalizing firms: what do we know after a decade (1993-2003) of scientific inquiry? International Business $\quad$ Review, 14(2), 147-166. doi:https://doi.org/10.1016/j.ibusrev.2004.04.006

Ripolles, M., Blesa, A., \& Monferrer, D. (2012). Factors enhancing the choice of higher resource commitment entry modes in international new ventures. International Business Review, 21(4), 648-666. doi:10.1016/j.ibusrev.2011.07.007

Romanello, R., \& Chiarvesio, M. (2019). Early internationalizing firms: 2004-2018. Journal of International Entrepreneurship, 17(2), 172-219. doi:10.1007/s10843-018-0241-8

Sigfusson, T., \& Harris, S. (2013). Domestic market context and international entrepreneurs' relationship portfolios. International Business Review, 22(1), 243-258. doi:https://doi.org/10.1016/j.ibusrev.2012.04.008

Sjodin, D. R., Parida, V., \& Kohtamaki, M. (2016). Capability configurations for advanced service offerings in manufacturing firms: Using fuzzy set qualitative comparative analysis. Journal of Business Research, 69(11), 5330-5335. doi:10.1016/j.jbusres.2016.04.133

Smith, S. (2016, April 19). Is globalisation dead?

Svensson, G. (2006). A quest for a common terminology: The concept of born glocals. Management Decision, 44(9), 1311-1317. doi:10.1108/00251740610707758

Svensson, G., \& Payan, J. M. (2009). Organizations that are international from inception: Terminology and research constellations - "academic protectionism" or “academic myopia”? Journal of Small Business and Enterprise Development, 16(3), 406-417. doi:10.1108/14626000910977134 
Teece, D. J. (2007). Explicating dynamic capabilities: The nature and microfoundations of (sustainable) enterprise performance. Strategic Management Journal, 28(13), 1319-1350. doi:10.1002/smj.640

Teece, D. J. (2012). Dynamic Capabilities: Routines versus Entrepreneurial Action. Journal of Management Studies, 49(8), 1395-1401. doi:10.1111/j.14676486.2012.01080.x

Teece, D. J. (2014). The foundations of enterprise performance: Dynamic and ordinary capabilities in an (economic) theory of firms. Academy of Management Perspectives, 28(4), 328-352. doi:10.5465/amp.2013.0116

Teece, D. J., Pisano, G., \& Shuen, A. (1997). Dynamic capabilities and strategic management. Strategic Management Journal, 18(7), 509-533. doi:10.1002/(Sici)1097-0266(199708)18:7<509::Aid-Smj882>3.0.Co;2-Z

Thomas, H., \& Pollock, T. (1999). From I - O economics' S - C - P paradigm through strategic groups to competence - based competition: reflections on the puzzle of competitive strategy. British Journal of Management, 10(2), 127-140. doi:https://doi.org/10.1111/1467-8551.00115

Tranfield, D., Denyer, D., \& Smart, P. (2003). Towards a methodology for developing evidence - informed management knowledge by means of systematic review. British Journal of Management, 14(3), 207-222. doi:https://doi.org/10.1111/1467-8551.00375

Urban, B., \& Sefalafala, M. R. (2015). The influence of entrepreneurial intensity and capabilities on internationalization and firm performance. South African Journal of Economic and Management Sciences, 18(2), 260-276. doi:http://dx.doi.org/10.17159/2222-3436/2015/v18n2a9

Venkatraman, N., \& Camillus, J. C. (1984). Exploring the concept of "fit" in strategic management. Academy of Management Review, 9(3), 513-525. doi:https://doi.org/10.5465/amr.1984.4279696

Waleczek, P., von den Driesch, T., Flatten, T. C., \& Brettel, M. (2019). On the dynamic bundles behind operations management and research and development. European Management Journal, 37(2), 175-187. doi:https://doi.org/10.1016/j.emj.2018.03.005

Wang, C. L., \& Ahmed, P. K. (2007). Dynamic capabilities: A review and research agenda. International Journal of Management Reviews, 9(1), 31-51. doi:10.1111/j.1468-2370.2007.00201.x

Weerawardena, J. (2003). Exploring the role of market learning capability in competitive strategy. European Journal of Marketing, 37(3/4), 407-429. doi:10.1108/03090560310459023

Weerawardena, J., Mort, G. S., \& Liesch, P. W. (2019). Capabilities development and deployment activities in born global B-to-B firms for early entry into 
international markets. Industrial Marketing Management, 78, 122-136. doi:10.1016/j.indmarman.2017.06.004

Weerawardena, J., Mort, G. S., Liesch, P. W., \& Knight, G. (2007). Conceptualizing accelerated internationalization in the born global firm: A dynamic capabilities perspective. Journal of World Business, 42(3), 294-306. doi:10.1016/j.jwb.2007.04.004

Weerawardena, J., Mort, G. S., Salunke, S., Knight, G., \& Liesch, P. W. (2014). The role of the market sub-system and the socio-technical sub-system in innovation and firm performance: A dynamic capabilities approach. Journal of the Academy of Marketing Science, 43(2), 221-239. doi:10.1007/s11747-014-0382-9

Wernerfelt, B. (1984). A resource - based view of the firm. Strategic Management Journal, 5(2), 171-180. doi:10.1002/smj.4250050207

Winter, S. G. (2003). Understanding dynamic capabilities. Strategic Management Journal, 24(10), 991-995. doi:https://doi.org/10.1002/smj.318

Wu, A. Q., \& Voss, H. (2015). When does absorptive capacity matter for international performance of firms? Evidence from China. International Business Review, 24(2), 344-351. doi:10.1016/j.ibusrev.2014.08.006

Zahra, S. A., \& Nielsen, A. P. (2002). Sources of capabilities, integration and technology commercialization. Strategic Management Journal, 23(5), 377-398. doi:https://doi.org/10.1002/smj.229

Zahra, S. A., Sapienza, H. J., \& Davidsson, P. (2006). Entrepreneurship and dynamic capabilities: A review, model and research agenda. Journal of Management Studies, 43(4), 917-955. doi:https://doi.org/10.1111/j.1467-6486.2006.00616.x

Zhang, M., Gao, Q., \& Cho, H.-S. (2017). The effect of sub-national institutions and international entrepreneurial capability on international performance of exportfocused SMEs: Evidence from China and South Korea. Journal of International Entrepreneurship, 15(1), 85-110. doi:10.1007/s10843-016-0196-6

Zhang, M., Sarker, S., \& Sarker, S. (2013). Drivers and export performance impacts of IT capability in 'born-global' firms: A cross-national study. Information Systems Journal, 23(5), 419-443. doi:10.1111/j.1365-2575.2012.00404.x

Zhang, M., Tansuhaj, P., \& McCullough, J. (2009). International entrepreneurial capability: The measurement and a comparison between born global firms and traditional exporters in China. Journal of International Entrepreneurship, 7(4), 292-322.

Zhang, M., \& Tansuhaj, P. S. (2007). Organizational culture, information technology capability, and performance: The case of born global firms. Multinational Business Review, 15(3), 43-78. doi:10.1108/1525383x200700012

Zhou, L., Wu, A., \& Barnes, B. R. (2012). The effects of early internationalization on performance outcomes in young international ventures: The mediating role of 
marketing capabilities. Journal of International Marketing, 20(4), 25-45. doi:10.1509/jim.12.0076

Zollo, M., \& Winter, S. G. (2002). Deliberate learning and the evolution of dynamic capabilities. Organization Science, 13(3), 339-351. 


\section{Appendix}

List of the 37 articles analysed for the literature review.

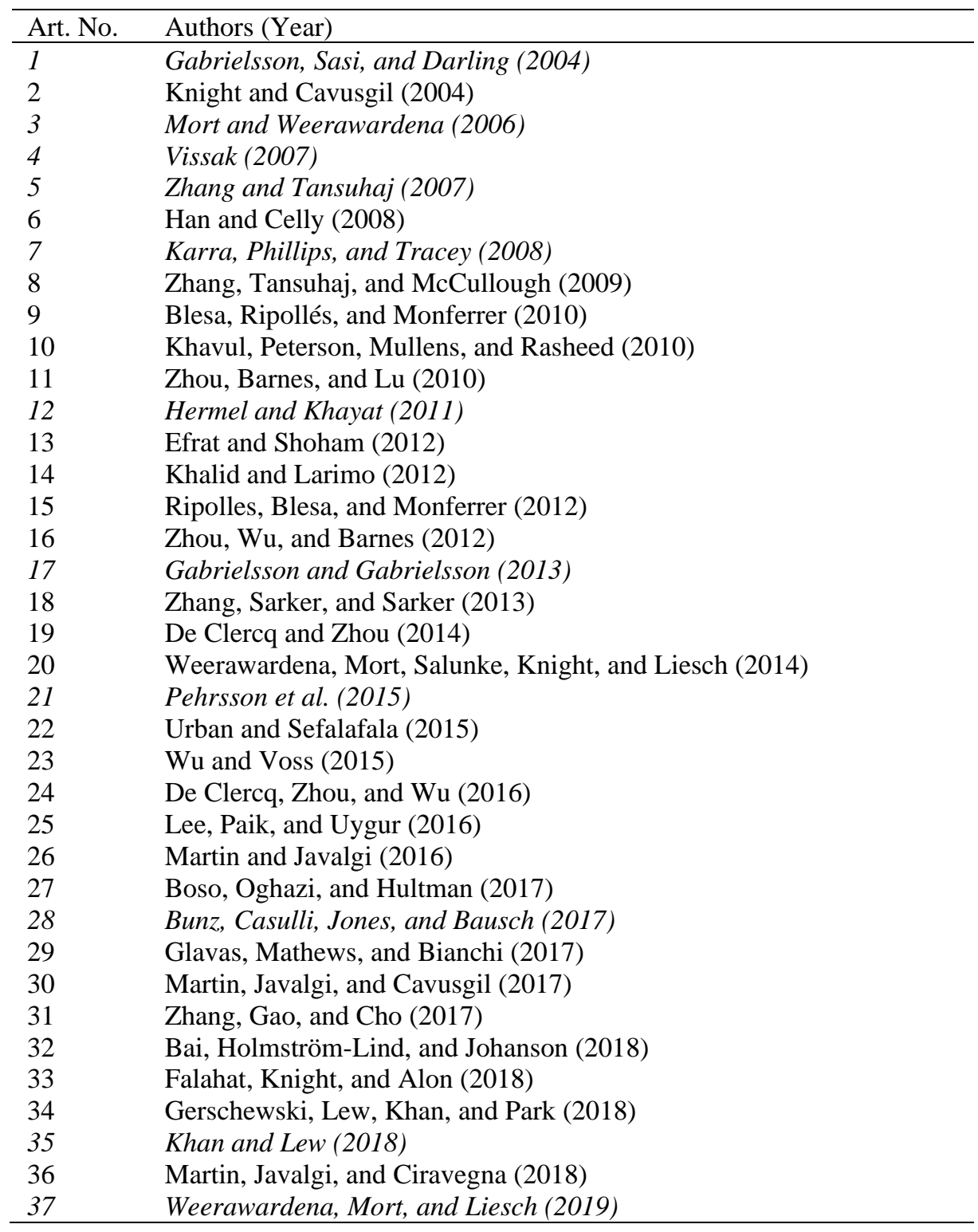

Note: Italics mean qualitative studies, remaining are quantitative studies; Chronologically ordered. 



\section{CHAPTER 4 Capability Bundles for International Performance of Technology-Based Early Internationalizing Firms}

An early version of the chapter has been presented as:

Jie, S., \& Harms, R. (2019, 2019/08/01). Dynamic bundle of capabilities and firm's international performance: A configurational analysis. Paper presented at the Academy of Management Proceedings, Boston.

This chapter is under review at Strategic Management Journal. 


\subsection{Introduction}

The Capability-based perspective (CBP) dominates the analysis of sustainable comparative firm advantage (Fainshmidt, Pezeshkan, Lance Frazier, Nair, \& Markowski, 2016). The CBP distinguishes between substantive capabilities (SCs) that firms use to create present value, and dynamic capabilities (DCs) that allow firms to reconfigure their resource and capability base (Teece, 2014). This distinction begets the question of how SC and DC are related to firm performance.

CBP researchers are divided about whether DCs have an independent relation to performance, or can only work in conjunction with substantive capabilities (Peteraf, Di Stefano, \& Verona, 2013). Teece, Pisano, and Shuen (1997) argue that DCs lead directly to firm performance. Eisenhardt and Martin (2000) counter that DCs do not contribute directly but only when they reconfigure SCs. Peteraf et al. (2013) reconcile these positions and suggest that a dynamic bundle, that is, combination SC and their dynamic counterparts, impact together on firm performance. Peteraf et al. (2013, p. 1407) argue that "really understanding dynamic capabilities requires seeing the complete picture and exploring interlinked dynamic bundles as a whole." Peteraf et al. (2013) thus introduce the idea of the dynamic bundle, as a combination of SC and DC of the same kind. They also introduce the idea of interlinkages between dynamic bundles, which we call "dynamic bundle configurations."

To explore whether SC and DC in isolation, or dynamic bundles or even dynamic bundle configurations impact on performance, we analyze which capability combinations suggest high firm performance, and which would suggest low performance. Despite tentative early quantitative evidence (Waleczek, von den Driesch, Flatten, \& Brettel, 2019), we argue that further exploration is needed to "help the researcher generate some new insights, which may then be a basis for further theoretical development or reexamination of existing theories" (BergSchlosser, De Meur, Rihoux, \& Ragin, 2009, p. 16). Hence, we use an inductive approach to analysis (Thomann \& Maggetti, 2017).

For this inductive analysis, on the interlinked relationships of capabilities, we need methods that can represent those interlinkages. We specify "interlinked" as "causally complex" (Misangyi et al., 2017). Causally complex relationships are those that exhibit conjunction, equifinality, and asymmetry (Misangyi et al., 
2017). Conjunction is that an outcome results from the interdependence of multiple conditions (Misangyi et al., 2017), such as the interdependencies between capabilities in dynamic bundles independence in configurations of dynamic bundles. Equifinality is that different starting conditions - that are different dynamic bundles or configurations of dynamic bundles - can lead to the same level of performance (Katz \& Kahn, 1978). Asymmetry is when attributes from one configuration can unrelated or even inversely related to the outcome in another configuration (Meyer, Tsui, \& Hinings, 1993). This implies that dynamic bundles or their configurations may be effective in one, or ineffective in another group of firms. Causally complex relationships can be explored with the fsQCA method (Ragin, 2009). The result of a fsQCA analysis are configurations of dynamic bundles capabilities that are related to high or to low performance.

Our exploration contributes to the overarching discussion on the relationship between capability types in corroborating empirical evidence for the dynamic bundle as a particular type of capability configuration. The results of our exploration support the potential of dynamic bundles as a perspective in the theoretical dispute on the direct or configurational performance impact of dynamic capabilities. We do not position this research as one of strong-inference (Greenwald, 2012) that solves this dispute. To solve this dispute, further research efforts are required. For those research efforts, we see the role of entirely deductive approaches to QCA, which are not yet fully developed (Fischer \& Maggetti, 2017; Thomann \& Maggetti, 2017).

Our exploration contributes to the literature on the capability-performance relationship in international entrepreneurship (Fainshmidt, Wenger, Pezeshkan, \& Mallon, 2019). Next to the support of dynamic bundles as a theoretical perspective in general, we identify the particular dynamic bundle configurations that are linked to the high performance of technology-based early internationalizing firms (TBEIF). Those TBEIF are a suitable research context for dynamic bundles, and at the same time a highly relevant research object by themselves (Gerschewski, Rose, \& Lindsay, 2015; Keupp \& Gassmann, 2009; Perényi \& Losoncz, 2018; Romanello \& Chiarvesio, 2019).

The practical relevance of our exploration is that managers and entrepreneurs can make strategic decisions so that they can close the gap between their firms' capability portfolio and an ideal-type capability portfolio that suggest high international performance. 


\section{$4.2 \quad$ Theory}

\subsubsection{The capability-based perspective}

The CBP argues that capabilities are related to firm performance (Al-Aali \& Teece, 2014; Knight \& Cavusgil, 2004; Teece et al., 1997). A capability is "a learned and stable pattern of collective activity" (Zollo \& Winter, 2002, p. 340). Capabilities help firms to perform strategic and primary tasks (Winter, 2003), to react to environmental uncertainty (Autio, George, \& Alexy, 2011), and to achieve organizational goals (Teece, 2014). The CBP holds that heterogeneous capability endowments are at the root of a firm's competitive advantage (Teece, 2007).

Firms use SCs to utilize resources to accomplish tasks, which, in turn, create value (Teece, 2014; Winter, 2003). SCs are also known as static (Collis, 1996), zero-level (Winter, 2003), operational (Helfat \& Peteraf, 2003), and ordinary capabilities (Teece, 2012). SCs involve administrative, operational, and governance-related functions that allow firms to accomplish tasks of higher quality and lower cost (Teece, 2014). Studies on international new firm performance illustrate the positive performance implications of SCs (Martin \& Javalgi, 2016; Ripollés \& Blesa, 2012).

Firms use DCs to sense environmental changes, formulate a response to those changes, and then take action to implement the response (Teece, 2014). DCs refer to "the capacity of an organization to purposefully create, extend, or modify its resource base" (Helfat, 2007, p. 1). They are particularly useful in addressing dynamics and uncertainties in (international) markets (De Clercq, Sapienza, Yavuz, \& Zhou, 2012). DCs contribute to firm performance because they (re)configure firm resources and SCs and, so, help to react to dynamic international business environments.

\subsubsection{The set-theoretic perspective on the capabilities-performance relationship}

A set-theoretic perspective is a valid approach to analyze capability-performance relationships. First, the central tenets of the set-theoretic perspective conjunction, equifinality, and asymmetry (Misangyi et al., 2017) - have their 
equivalents in capability theory. Second, empirical evidence suggests that these tenets hold in reality.

\section{Conjunction}

Conjunction means that "outcomes rarely have a single cause but rather result from the interdependence of multiple conditions" (Misangyi et al., 2017, p. 256). Analyses from a set-theoretic perspective focus on the joint effects of the conditions rather than their independent effects (Lisboa, Skarmeas, \& Saridakis, 2016).

A conjunction is a core quality of the relationship between capabilities and performance (Fainshmidt et al., 2019). First, capabilities are nested within a hierarchical order, where higher-order capabilities reconfigure lower-order capabilities, and the lowest-order capabilities reconfigure the resources base (Heimeriks, Schijven, \& Gates, 2012). Nesting suggests that capabilities occur together and may have a joint performance relationship. Second, a novel organizing framework for capabilities suggests that SCs may be antecedents of DCs and that those then influence performance by being moderated by or mediated through capabilities and resources (Schilke, Hu, \& Helfat, 2017). The different temporal logics in the relationship between SCs and DCs suggest that combinations of effects - in other words, conjunction - are at play. Third, a firm that is strong on SCs and weak on DCs may perform well today but may fail to generate a long-term advantage (Lichtenstein \& Brush, 2001). A firm that is weak on SCs and strong on DCs may not perform well today. Likewise, it may not possess any SCs that its DCs can reconfigure. Drawing together these three lines of argument, we propose that it is a conjunction of SCs and DCs that leads to sustainable competitive advantage.

Empirical support for the conjunction between DCs and other capabilities comes from studies on DC mediation. For example, Jantunen, Tarkiainen, Chari, and Oghazi (2018) show that DCs, in combination with changes in management and practices, are related to high performance.

\section{Equifinality}

Equifinality refers to a situation where "a system can reach the same final state, from different initial conditions and by a variety of different paths" (Katz \& Kahn, 1978, p. 30; as cited by Fiss (2011, p. 394)). Equifinality exists when firms achieve their goals through alternative strategies. 
Equifinality characterizes the capability-performance relationship as well. First, structural functionalism (Mintzberg, 1980) argues that different capabilities can be structurally equivalent in terms of achieving organizational goals. Accordingly, the link between capabilities and organizational performance is equifinal. Second, firms' capabilities are idiosyncratic and difficult to imitate (Gelhard, von Delft, \& Gudergan, 2016; Helfat, 2007; Teece, 2007). Hence, firms with unique capabilities that achieve similar performance reflect the principle of equifinality, too. Third, specific capabilities exhibit features that are associated with effective processes across firms (Eisenhardt \& Martin, 2000). These specific capabilities reflect equally effective ways of dealing with specific organizational functions. Therefore, "dynamic capabilities have greater equifinality [...] across firms" (Eisenhardt \& Martin, 2000, p. 1106).

The concept of equifinality in set-theoretic research on capabilities has received empirical support. For example, Gelhard et al. (2016) present four capability solutions in dynamic/stable environments that achieve high strategic performance. Also, Jantunen et al. (2018) show that multiple capability/change configurations are related to high performance.

\section{Asymmetry}

Asymmetry is the principle that attributes "found to be causally related in one configuration may be unrelated or even inversely related in another" (Meyer et al., 1993, p. 1178). In a symmetric relationship, high/low values of $\mathrm{X}$ (independent attributes) are 'both necessary and sufficient' for high/low values of Y (dependent attributes) to occur (Woodside, 2013, p. 464). In an asymmetric relationship, high/low values of $\mathrm{X}$ are either 'sufficient but not necessary' or 'necessary but not sufficient' for high/low values of Y to occur (Woodside, 2013).

Capabilities and their performance relationships are asymmetric. First, DCs may not lead directly to a sustainable competitive advantage but only through complementary SCs (Eisenhardt \& Martin, 2000). This relationship indicates that DCs are 'necessary but not sufficient' factors for firms' sustainable competitive advantage. Second, equifinality in capability-performance relationships indicates that capabilities could be 'sufficient but not necessary' to achieve performance. Both 'necessary but not sufficient' and 'sufficient but not necessary' causalities imply asymmetry between capabilities and firm performance. 
The concept of asymmetry in set-theoretic capabilities research has obtained empirical support. For example, the development and transaction capabilities in low-tech firms are found to be necessary but not sufficient for high innovation performance. However, this relation becomes sufficient when combined with management or operational capability (Reichert, Torugsa, Zawislak, \& Arundel, 2016).

\subsubsection{Dynamic bundles and configurations of dynamic bundles}

Dynamic bundles are combinations of SCs and DCs of the same functional area, e.g., marketing, technology, and networking (Waleczek et al., 2019). The concept of the dynamic bundle was introduced to resolve disputes over the performance implications of DCs (Peteraf et al., 2013). First, Teece et al. (1997) argue that DCs lead directly to firm performance. However, Eisenhardt and Martin (2000) counter that DCs do not contribute directly but only when SCs are reconfigured. Peteraf et al. (2013) then suggest that, in a dynamic bundle, its dynamic components work in conjunction with the substantive components to achieve performance (Di Stefano, Peteraf, \& Verona, 2014; Waleczek et al., 2019). Such combinative effects in dynamic bundles may explain performance better than the individual effect of each type of capability (Karna, Richter, \& Riesenkampff, 2016; Song, Droge, Hanvanich, \& Calantone, 2005). Despite the theoretical appeal of the concept of the dynamic bundle of SC and DC capabilities of the same kind, very few studies provide empirical evidence, (Mort \& Weerawardena, 2006; Weerawardena, Mort, \& Liesch, 2019).

Configurations of dynamic bundles, rather than dynamic bundles alone, or even singular capabilities, are associated with superior international performance. This argument is based on management systems theory (Mintzberg, 1980), which argues that firms need a set of functions and, hence, a set of dynamic bundles (Teece, 2014) to operate. The idea of capability complementarity (Ennen \& Richter, 2010) or capability configurations (Sjödin, Parida, \& Kohtamäki, 2016) illustrates that capabilities contribute more strongly to firm performance when they operate in combinations (Su, Peng, Shen, \& Xiao, 2013). 


\subsubsection{Dynamic bundles for international performance}

Technology-based early internationalizing firms as the research context

Dynamic bundles and configurations of dynamic bundles may be effective in a variety of firm types. We chose TBEIF as a proper study context. A suitable study context is one where we expect a large degree of heterogeneity in the distribution of capabilities. Such is the context of capabilities related to the international performance of technology companies in Chinese firms. First, capabilities that are relevant for international performance may be particularly unevenly distributed because China has opened up to international entrepreneurship only in the last few decades (Tse, 2016), and many Chinese entrepreneurs still focus on the vast home market (Chin, Liu, \& Yang, 2015). Second, in reference to the fact that DC perform best in dynamic environments, dynamic bundles may be most effective in dynamic environments as well. Thus we argue that the context of the international technology business is highly dynamic as a function of technological change (Danneels, 2002) and business and political forces at work in international business (Li, He, \& Lin, 2018). In sum, we contend that the capabilities for the international performance of Chinese TBEIFs are scarce and are applied in a dynamic market. Hence, our setting offers a suitable study context.

TBEIF are technology-based businesses that begin to internationalize soon after their foundation (based on Rialp, Rialp, \& Knight, 2005; Romanello \& Chiarvesio, 2019). To explain their international performance, the capabilitiesbased perspective (CBP) emerged as a critical theoretical foundation (Gerschewski et al., 2015; Keupp \& Gassmann, 2009; Romanello \& Chiarvesio, 2019). A recent review identified marketing, technology, and networking capabilities as key capabilities for TBEIF performance (Jie \& Harms, 2018). These will now be explored further.

\section{International marketing capabilities: Substantive, Dynamic and Bundle}

Substantive international marketing capabilities are at the core of performing the marketing function (Morgan, Vorhies, \& Mason, 2009; Vorhies \& Morgan, 2005). Substantive marketing capabilities allow firms to understand better their customers' needs (Fowler, King, Marsh, \& Victor, 2000), to deliver competitive products/services (Tan \& Sousa, 2015), and to effectively analyze competitors (Protogerou, Caloghirou, \& Lioukas, 2012). With strong substantive international marketing capabilities, firms can manage cultural differences, 
language barriers, economic development differences, and local competitions across global markets (Knight \& Cavusgil, 2004; Martin, Javalgi, \& Cavusgil, 2017; Morgan et al., 2009).

Dynamic international marketing capabilities are activities for "the creation, use, and integration of market knowledge and marketing resources to match and create market and technological change" (Bruni \& Verona, 2009, pp. 103, emphasis added) in an international context. They go beyond SCs in that they enable the firm to address market and technology changes (Morgan, 2012; Tzokas, Kim, Akbar, \& Al-Dajani, 2015). Accordingly, firms can anticipate market changes, reconfigure their resource bases, and enhance marketing capabilities to drive performance (Morgan, 2012). For instance, dynamic international marketing capabilities help Chinese startups to achieve learning advantages and address rapidly changing global markets that, in turn, contribute to international growth (Zhou, Wu, \& Barnes, 2012).

A dynamic bundle of international marketing capabilities is a combination of substantive and dynamic international marketing capabilities. This bundle allows firms to obtain new market knowledge continuously and integrate it into origination to modify operational routines so that products and services can be delivered more effectively to international markets. SCs and DCs interact in the dynamic marketing bundle. For instance, Vorhies, Morgan, and Autry (2009) suggest that firms' architectural marketing capabilities (DCs) facilitate their specialized marketing capabilities (SCs) on planning and coordinating resources so that the firm can implement marketing strategies more effectively. They show that the integration of these two marketing capabilities improves market effectiveness and enhances firms' cash flow. Vorhies, Orr, and Bush (2011) demonstrate that dynamic marketing capabilities coordinate and create new substantive marketing capabilities. The modified marketing capabilities contribute significantly to the firms' financial performance. These arguments and empirical evidence suggest that firms that possess a dynamic bundle of international marketing capabilities perform better.

\section{Technological capabilities: Substantive, Dynamic and Bundle}

Substantive technological capabilities are related to the use of existing technology and existing innovation processes to engage in incremental innovation (Menguc, Auh, \& Yannopoulos, 2014). Substantive technological capabilities increase operational efficiency (Isobe, Makino, \& Montgomery, 
2008), allow firms to be more innovative (Tzokas et al., 2015) and to develop differentiated products (Lee, Lee, \& Pennings, 2001). With these efficient operations and innovation processes, firms can effectively cater to market demands (Protogerou et al., 2012), which, in turn, contributes to firm performance (Flor \& Oltra, 2005). Flor and Oltra (2005) show that improvements in technological production capabilities positively influence firms' export performance.

Dynamic technological capabilities are capabilities that firms use to acquire new technologies, and substantially (as opposed to incrementally) innovate their existing technology base and product portfolios. Dynamic technological capabilities refer to searching (Peng, Schroeder, \& Shah, 2008), and seizing and transforming new technologies (Lichtenthaler \& Muethel, 2012a). Capabilities such as dynamic information technology capabilities (Zhang \& Tansuhaj, 2007) and dynamic technology/research and development capabilities (Efrat \& Shoham, 2012) contribute to the international performance of INVs through mechanisms such as developing high value-added products, efficient problem solving, and coordinating knowledge. For example, a study on born-global firms demonstrates that focusing on information technology capabilities to develop new products (hence, DC) contributes to export performance (Zhang, Sarker, \& Sarker, 2013).

A dynamic bundle of technological capabilities combines the dynamic components of sensing new technologies and integrates them with substantive technological capabilities. With such a bundle, firms can achieve a sustainable competitive advantage (Waleczek et al., 2019). Previous studies point to both qualitative and quantitative evidence on the contribution of a dynamic bundle of technological capabilities to firm performance. For instance, Seyed Kalali and Heidari (2016) show that firms with a high degree of dynamic technological capabilities are better at designing methods to update their services, at developing IT-based tools and systems to improve their consulting skills, and at integrating knowledge that strengthens employees' existing knowledge. Moreover, Waleczek et al. (2019) show a significant mediating effect of substantive technological capabilities in the relationship between dynamic technological capabilities and firm performance. The mediation indicates that the joint influence of dynamic and substantive capabilities in the dynamic bundle of technological capabilities contributes to firm performance. 
International networking capabilities: Substantive, Dynamic and Bundle

Substantive international networking capabilities are the set of activities that firms use to maintain the relationships with international partners and to obtain resources from them (Walter, Auer, \& Ritter, 2006). These networking capabilities help firms to share the risk, access new markets and technologies, and increase the speed of product launches (Pittaway, Robertson, Munir, Denyer, \& Neely, 2004). Gabrielsson and Gabrielsson (2013) demonstrate that international new ventures use networks and contacts to quickly establish international subsidiaries and distributors that, in turn, promote international growth.

Dynamic international networking capabilities are a set of activities designed to develop new international networks and to gain, integrate, and reconfigure knowledge from networks. Firms build new intentional, strategic alliances with their networking capability (Hitt, Dacin, Levitas, Arregle, \& Borza, 2000). These strategic alliances provide information or resources (Lee et al., 2001). Entrepreneurs can use these new resources and information to uncover opportunities (Lee et al., 2001). For instance, dynamic networking capabilities enable the owners/managers of born-globals to integrate and reconfigure resource combinations, leading to international sales (Mort \& Weerawardena, 2006). The continuous reconfiguring of supplier-relationship portfolios contributes to product innovation and the overall performance of automotive firms' performance (Mitrega, Forkmann, Zaefarian, \& Henneberg, 2017).

The dynamic bundle of international networking capabilities is a combination of substantive and dynamic international networking capabilities. This bundle helps firms to continuously find new partners and integrate new knowledge to modify old networking routines, and international partnerships are more effectively maintained. Therefore, firms with strong dynamic network bundle are more efficient in developing and retaining new partnerships. These international networks help firms to acquire new information and achieve a sustainable competitive advantage (Parida, Pemartín, \& Frishammar, 2009). Mort and Weerawardena (2006) and Weerawardena et al. (2019) found that born-global firms launch internationalization with substantive networking capabilities, followed by secondary (dynamic) networking capabilities in which new networks are actively developed and old capabilities reconfigured. 


\section{Configuration of the dynamic bundle of capabilities}

We now illustrate the concept of configurations of different types of capabilities on the example of the international entrepreneurship literature. These examples do not apply dynamic bundles, nor do they apply a set-theoretic analysis. However, they can illustrate the performance implications of an interplay between configurations of different kinds. We found analyses of the relationship between marketing and technology capabilities (Song et al., 2005; Su et al., 2013), marketing and networking capabilities (Wang \& Kim, 2017), and networking and technology capabilities (Chen, Zou, \& Wang, 2009; Yang, Huang, Wang, \& Feng, 2018).

For example, Song et al. (2005) show that the combination of marketing capabilities and technological capabilities creates an additional positive effect on firm performance. This combination helps to reconfigure competencies and to reduce resource deficiency. They demonstrate complementary effects from the integration of technological capabilities and marketing capabilities on firm performance and suggest that, through this interaction, firms can deal with technology and marketing dynamisms more effectively. Figure 4.1 summarizes our discussion on the relationship between SCs, DCs, dynamic bundles, and configuration of dynamic bundles on international performance.
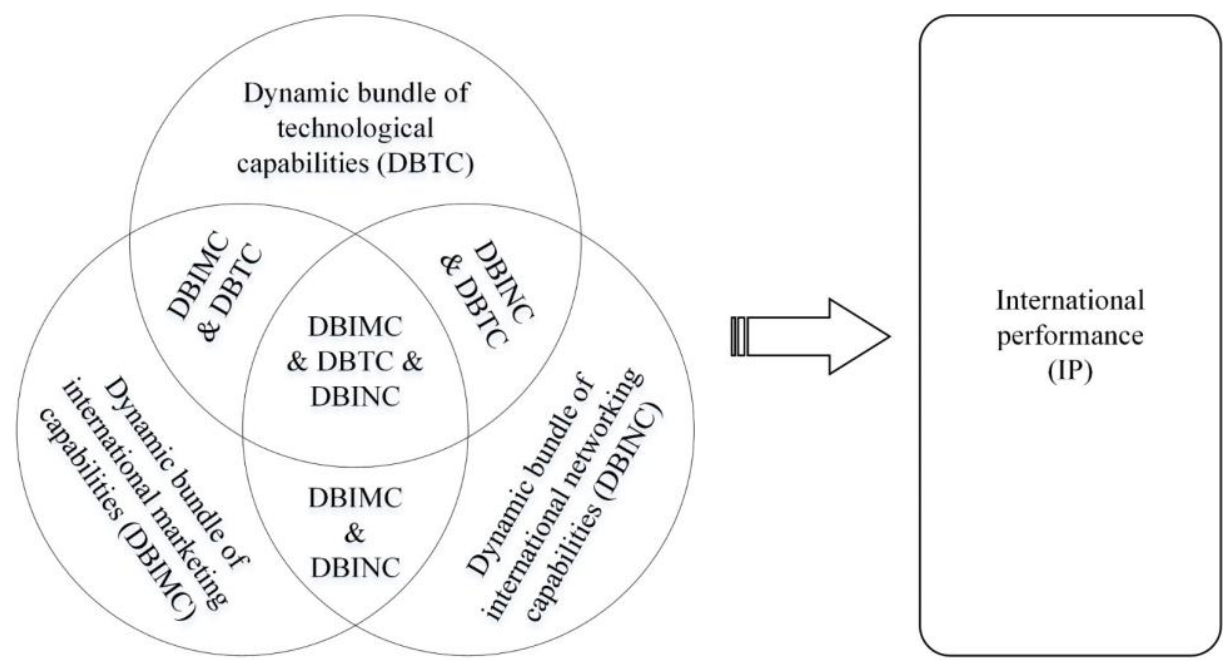

Figure 4.1 Set-theoretic framework. 


\subsection{Method}

\subsubsection{Sample and data collection}

We draw our sample from the population of TBEIFs in China. Each firm was required to: have a primary business based on technology; be younger than nine years (Baum, Schwens, \& Kabst, 2011; De Clercq \& Zhou, 2014); have a minimum of 5 percent international revenue; be privately owned, and be independently operated.

We sampled TBEIF from the Xi'an Hi-tech Industries Development zone, one of the earliest and most successful high-tech zones in China (Foreign-InvestmentPromotion-Bureau, 2019; Walcott, 2003), on which many other zones were modeled. We acknowledge that, even though the sampling context is a typical one for China, we are not aiming for statistical generalizability but, instead, theoretical generalization via criterion sampling (Schreier, 2018). This sampling is consistent with our choice of inductive QCA (Thomann \& Maggetti, 2017), which has no restrictive sample size requirements. Yet, we are in the loosens sample size requirements, and we are in the range of large-n QCA studies (Greckhamer, Misangyi, \& Fiss, 2013).

Data were collected from May to November 2018. We obtained contact addresses from park websites and park management (1587 firms). Prescreening based on the maximum age resulted in a list of 599 companies. Each company was contacted by mail and telephone. This yielded 64 responses. 24 additional responses were obtained using snowball sampling (Goodman, 1961). There were no statistical differences between respondents from the phone and the snowball sampling. In total we received 88 responses from TBEIF that that met all sampling criteria (see Table 4.1). 
Table 4.1 Sample descriptions $(\mathrm{N}=88)$.

\begin{tabular}{|c|c|c|c|c|c|}
\hline Indicators & $\begin{array}{l}\text { Number } \\
(\%)\end{array}$ & Mean & $\begin{array}{l}\text { Std. } \\
\text { Dv. }\end{array}$ & Min & Max \\
\hline Firm age & & 6.08 & 2.50 & 1 & 9 \\
\hline Firm size & & 110.43 & 94.85 & 2 & 299 \\
\hline Firm age at first internationalization & & 4.98 & 2.37 & 1 & 9 \\
\hline International revenue ratio* & & 7.63 & 2.49 & 3 & 12 \\
\hline \multicolumn{6}{|l|}{ Sectors } \\
\hline Information Technology & $21(23.9 \%)$ & & & & \\
\hline Equipment \& Electronics & $34(38.6 \%)$ & & & & \\
\hline Biological \& Material & $16(18.2 \%)$ & & & & \\
\hline Service \& Other manufacturing & $17(19.3 \%)$ & & & & \\
\hline
\end{tabular}

We pre-tested the survey on nine entrepreneurs and ten academics for item wording and comprehension (DeVellis, 2016). The outcome and the condition were surveyed by different people in the firm to counter social desirability bias (Ganster, Hennessey, \& Luthans, 1983) and common method bias (Chang, van Witteloostuijn, \& Eden, 2010). We also surveyed the SCs en bloc, followed by the DCs en bloc, to avoid survey assimilation effects (Van de Walle \& Van Ryzin, 2011).

\subsubsection{Operationalization}

To measure international performance, we aggregated objective, industryrelated, and subjective dimensions of international revenue (Gerschewski \& Xiao, 2015) to acknowledge the multidimensional nature of performance (Coviello \& Yli-Renko, 2016).

To measure capabilities, we used a systematic literature analysis on capabilities in international entrepreneurship research (Jie \& Harms, 2018). From this pool, we selected the one that best reflected the respective working definition to safeguard content validity. Two researchers were involved in this step. If necessary, the item formulations were carefully adapted to reflect the (1) international nature of the capability, e.g., by adding 'international'; (2) the TBEIF nature of our sample, e.g., by replacing 'corporate' with 'venture'; (3) the 
capability nature of 'actions,' e.g., by replacing 'orientation' with 'action.' The complete list of adaptations can be obtained from the authors.

All capabilities are measured with first-order reflective and second-order formative scales. The items were translated into Chinese and translated back into English to guarantee their validity and avoid cultural bias (De Clercq \& Zhou, 2014). Table 4.2 provides the description and literature source, and Table 4.3 gives descriptive statistics.

\subsubsection{Method of analysis}

This study builds on complex causality. A method that addresses this complex causality is fuzzy-set qualitative comparative analysis (fsQCA, Rihoux \& Ragin, 2009b). FsQCA builds on fuzzy-set theory and discovers causal patterns by examining the attributes of configurations that belong in the outcome set (Rihoux \& Ragin, 2009a).

FsQCA follows a sequence of calibration, necessary condition analysis, truthtable build, and truth-table minimization (Fiss, 2011). Calibration transforms original values into membership scores that range from 0.0 (full nonmembership) to 1.0 (full membership). We found no reasons for natural calibration points in the distribution of data on our variables. Here, we set three calibration anchors ('0.0', ' $0.5^{\prime}$ ', and ' $1.0^{\prime}$ ') at a value close to the $5^{\text {th }}, 50^{\text {th }}$, and $95^{\text {th }}$ percentiles of the distribution (Beynon, Jones, \& Pickernell, 2016). The original percentiles and final cut-off points are shown in Table 4.3. 


\section{Table 4.2 Operationalization.}

\begin{tabular}{|c|c|c|}
\hline Construct & Measurement & References \\
\hline $\begin{array}{l}\text { International } \\
\text { performance }\end{array}$ & $\begin{array}{l}\text { 9-item Likert scale }(\alpha=.903) \text {; the ratio }(\alpha=.713) \text {, growth }(\alpha=.807) \text {, and profitability } \\
(\alpha=.739) \text { of ventures' international revenue from an objective, industry-related, and } \\
\text { subjective perspective. }\end{array}$ & $\begin{array}{l}\text { Gerschewski and } \\
\text { Xiao (2015) }\end{array}$ \\
\hline $\begin{array}{l}\text { Substantive international } \\
\text { marketing capabilities }\end{array}$ & $\begin{array}{l}\text { 16-item Likert scale }(\alpha=.923) \text {; the extent to which the venture conducts activities for } \\
\text { the efficient and effective execution of its marketing strategies to create value. }\end{array}$ & $\begin{array}{l}\text { Vorhies and } \\
\text { Morgan (2005) }\end{array}$ \\
\hline $\begin{array}{l}\text { Dynamic international } \\
\text { marketing capabilities }\end{array}$ & $\begin{array}{l}\text { 16-item Likert scale }(\alpha=.926) \text {; the degree to which the venture conducts activities to } \\
\text { absorb market knowledge and integrate the knowledge into the rest of the } \\
\text { organization. }\end{array}$ & $\begin{array}{l}\text { Flatten, Engelen, } \\
\text { Zahra, and Brettel } \\
(2011)\end{array}$ \\
\hline $\begin{array}{l}\text { Substantive } \\
\text { technological capabilities }\end{array}$ & $\begin{array}{l}12 \text {-item Likert scale }(\alpha=.915) \text {; the extent to which the venture conducts activities to } \\
\text { use existing technology with existing innovation processes to engage in incremental } \\
\text { innovation. }\end{array}$ & $\begin{array}{l}\text { Peng et al. (2008); } \\
\text { Lichtenthaler and } \\
\text { Muethel (2012b) }\end{array}$ \\
\hline $\begin{array}{l}\text { Dynamic technological } \\
\text { capabilities }\end{array}$ & $\begin{array}{l}\text { 12-item Likert scale }(\alpha=.926) \text {; the degree to which the venture conducts activities to } \\
\text { acquire new technologies and make innovations to update existing technologies and } \\
\text { develop new products/services. }\end{array}$ & $\begin{array}{l}\text { Peng et al. (2008); } \\
\text { Lichtenthaler and } \\
\text { Muethel (2012b) }\end{array}$ \\
\hline $\begin{array}{l}\text { Substantive international } \\
\text { networking capabilities }\end{array}$ & $\begin{array}{l}\text { 14-item Likert scale }(\alpha=.936) \text {; the extent to which the venture conducts activities to } \\
\text { maintain the relationships with partners and try to get resources from these partners. }\end{array}$ & Walter et al. (2006) \\
\hline $\begin{array}{l}\text { Dynamic international } \\
\text { networking capabilities }\end{array}$ & $\begin{array}{l}\text { 16-item Likert scale }(\alpha=.913) \text {; the degree to which the venture conduct activities to } \\
\text { develop new networks and gain, integrate, and reconfigure knowledge from network } \\
\text { relationships to support innovations and identify new opportunities. }\end{array}$ & $\begin{array}{l}\text { Bonner, Kim, and } \\
\text { Cavusgil (2005) }\end{array}$ \\
\hline
\end{tabular}


Table 4.3 Correlations, descriptive statistics, and calibration cut-offs.

\begin{tabular}{llllllll}
\hline & IP & SIMC & DIMC & STC & DTC & SINC & DINC \\
\hline SIMC & $.640^{* *}$ & & & & & & \\
DIMC & $.497^{* *}$ & $.744^{* *}$ & & & & & \\
STC & .109 & $.342^{* *}$ & $.477^{* *}$ & & & & \\
DTC & .111 & $.270^{*}$ & $.382^{* *}$ & $.787^{* *}$ & & & \\
SINC & $.527^{* *}$ & $.589^{* *}$ & $.665^{* *}$ & $.412^{* *}$ & $.417^{* *}$ & & \\
DINC & $.417^{* *}$ & $.466^{* *}$ & $.600^{* *}$ & $.527^{* *}$ & $.444^{* *}$ & $.765^{* *}$ & \\
\hline Minimum & 1.67 & 2.00 & 1.56 & 1.92 & 1.75 & 1.86 & 2.63 \\
Maximum & 5.00 & 5.00 & 5.00 & 5.00 & 5.00 & 5.00 & 5.00 \\
Mean & 3.45 & 3.63 & 3.89 & 3.99 & 3.85 & 3.87 & 3.96 \\
Std. Deviation & 0.77 & 0.71 & 0.66 & 0.64 & 0.73 & 0.70 & 0.59 \\
$5^{\text {th }}$ percentile & 2.11 & 2.22 & 2.84 & 3.00 & 2.50 & 2.57 & 3.00 \\
50 ${ }^{\text {th }}$ percentile & 3.44 & 3.69 & 3.97 & 4.00 & 3.92 & 3.93 & 3.94 \\
95 $5^{\text {th }}$ percentile & 4.67 & 4.75 & 4.94 & 5.00 & 4.92 & 5.00 & 5.00 \\
cut-off: 0.0 & 2.11 & 2.22 & 2.84 & 3.00 & 2.50 & 2.57 & 3.00 \\
cut-off: 0.5 & 3.45 & 3.70 & 3.95 & 4.01 & 3.93 & 3.94 & 3.95 \\
cut-off: 1.0 & 4.67 & 4.75 & 4.94 & 5.00 & 4.92 & 5.00 & 5.00 \\
\hline
\end{tabular}

Notes: IP = International performance; SIMC = Substantive international marketing capabilities; DIMC = Dynamic international marketing capabilities; STC $=$ Substantive technological capabilities; DTC = Dynamic technological capabilities; SINC = Substantive international networking capabilities; DINC $=$ Dynamic international networking capabilities. ${ }^{* *}$, correlation is significant at the 0.01 level (2-tailed). $\mathrm{N}=88$. 


\section{$4.4 \quad$ Results}

A necessary condition is one that must be present for the outcome to occur, but its presence does not guarantee that occurrence. A condition is necessary when its consistency and coverage scores are above 0.90 (Greckhamer, Furnari, Fiss, \& Aguilera, 2018). Consistency indicates how closely a perfect subset relation is approximated. Coverage gauges the degree to which causal combinations are relevant to the outcome (Ragin, 2009). Table 4.4 reports the necessity analysis and shows no necessary capability for either high or low international performance.

Table 4.4 Necessary condition analysis results.

\begin{tabular}{lllll}
\hline Conditions & \multicolumn{2}{l}{ Outcome } & & \multicolumn{2}{l}{ Low International performance } \\
& \multicolumn{2}{l}{ High International performance } & \multicolumn{2}{l}{ Coverage } \\
& Consistency & Coverage & Consistency & C \\
\hline SIMC & 0.82 & 0.82 & 0.54 & 0.52 \\
$\sim$ SIMC & 0.53 & 0.54 & 0.82 & 0.81 \\
DIMC & 0.75 & 0.77 & 0.54 & 0.54 \\
$\sim$ DIMC & 0.55 & 0.55 & 0.77 & 0.75 \\
STC & 0.70 & 0.71 & 0.61 & 0.59 \\
$\sim$ STC & 0.59 & 0.61 & 0.70 & 0.69 \\
DTC & 0.72 & 0.71 & 0.62 & 0.60 \\
$\sim$ DTC & 0.59 & 0.62 & 0.69 & 0.70 \\
SINC & 0.78 & 0.79 & 0.55 & 0.54 \\
$\sim$ SINC & 0.55 & 0.56 & 0.79 & 0.78 \\
DINC & 0.75 & 0.77 & 0.54 & 0.54 \\
$\sim$ DINC & 0.55 & 0.56 & 0.77 & 0.74 \\
\hline
\end{tabular}

Notes: The symbol $(\sim)$ represents the negation of the condition. SIMC $=$ Substantive international marketing capabilities; DIMC $=$ Dynamic international marketing capabilities; STC = Substantive technological capabilities; DTC = Dynamic technological capabilities; SINC = Substantive international networking capabilities; DINC = Dynamic international networking capabilities.

We use a consistency threshold of 0.80 (Schneider \& Wagemann, 2012), a proportional reduction in inconsistency threshold of 0.65 (Greckhamer, 2016a), and a frequency of 1 case (so as to include as many cases as possible in our smallsize sample) to build the truth table (see Table 4.5 for a simplified version, which includes only configurations with positive outcomes). The fsQCA algorithm 
reduces the truth table to a solution table. The solution table comprises simplified combinations of conditions from counterfactual analysis and logical minimization (Muñoz \& Kibler, 2016; Ragin, 2009). Table 4.6 presents the results of the configurational analysis for high international performance. Table 4.6 also shows the differences between core (large circles) and peripheral conditions (small circles).

Table 4.5 Simplified truth table for High international performance.

\begin{tabular}{lllllllll}
\hline SIMC & DIMC & STC & DTC & SINC & $\begin{array}{l}\text { DINC } \\
\text { Case } \\
\#\end{array}$ & $\begin{array}{l}\text { Raw } \\
\text { consis. }\end{array}$ & $\begin{array}{l}\text { PRI } \\
\text { consis. }\end{array}$ \\
\hline 1 & 1 & 1 & 1 & 1 & 1 & 22 & 0.89 & 0.81 \\
1 & 1 & 0 & 1 & 1 & 1 & 1 & 0.93 & 0.78 \\
1 & 0 & 0 & 0 & 1 & 1 & 1 & 0.94 & 0.74 \\
1 & 1 & 0 & 0 & 1 & 1 & 2 & 0.91 & 0.73 \\
1 & 0 & 1 & 1 & 1 & 1 & 1 & 0.92 & 0.70 \\
1 & 1 & 1 & 0 & 1 & 1 & 1 & 0.91 & 0.70 \\
0 & 1 & 0 & 0 & 1 & 1 & 2 & 0.92 & 0.66 \\
0 & 0 & 0 & 0 & 1 & 1 & 1 & 0.93 & 0.65 \\
1 & 1 & 1 & 0 & 0 & 1 & 1 & 0.92 & 0.65 \\
\hline
\end{tabular}

Notes: SIMC $=$ Substantive international marketing capabilities; DIMC = Dynamic international marketing capabilities; STC $=$ Substantive technological capabilities; DTC $=$ Dynamic technological capabilities; SINC $=$ Substantive international networking capabilities; DINC = Dynamic international networking capabilities. Consistency cut-off: 0.8 ; frequency cut-off: 1 case; PRI consistency cut-off: 0.65 .

The results show a high degree of consistency: individual solutions and overall consistency are at least 0.88 . The total coverage is 0.69 , which suggests that these solutions explain a high proportion of the outcome. 
Table 4.6 Capability configurations for High international performance.

\begin{tabular}{|c|c|c|c|c|}
\hline \multirow[t]{2}{*}{ Conditions } & \multicolumn{4}{|c|}{ Solutions } \\
\hline & 1 & $2 \mathrm{a}$ & $2 b$ & 3 \\
\hline Substantive international & O & & 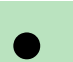 & \\
\hline $\begin{array}{l}\text { Dynamic international marketing } \\
\text { capabilities }\end{array}$ & - & - & & \\
\hline $\begin{array}{l}\text { Substantive technological } \\
\text { capabilities }\end{array}$ & C & & $\bullet$ & $\otimes$ \\
\hline $\begin{array}{l}\text { Dynamic technological } \\
\text { capabilities }\end{array}$ & $\otimes$ & & • & $\otimes$ \\
\hline $\begin{array}{l}\text { Substantive international } \\
\text { networking capabilities }\end{array}$ & & & & \\
\hline $\begin{array}{l}\text { Dynamic international networking } \\
\text { capabilities }\end{array}$ & & & & \\
\hline Consistency & 0.91 & 0.88 & 0.89 & 0.90 \\
\hline Raw coverage & 0.30 & 0.60 & 0.54 & 0.39 \\
\hline Unique coverage & 0.02 & 0.03 & 0.01 & 0.05 \\
\hline Overall solution consistency & & & & \\
\hline Overall solution coverage & & & & \\
\hline
\end{tabular}

Notes: $\mathbf{O}=$ core condition present; $\bullet$ = peripheral condition present; $\boldsymbol{\bigotimes}=$ core condition absent; $\otimes=$ peripheral condition absent; blank space $=$ does not care. Consistency cut-off: 0.88 ; frequency cut-off: 1 .

Firms in solution 1 ('established marketers') have a dynamic bundle of international marketing capabilities, substantive technological, and dynamic international networking capabilities. They do not have dynamic technological capabilities, and substantive international networking capabilities are not relevant to the high international performance for these firms. Firms in solutions $2 \mathrm{a}$ and $2 \mathrm{~b}$ both have the dynamic network bundle, and international marketing SCs are core conditions. In firms in solution $2 \mathrm{a}$, the presence of international marketing DCs reinforces core conditions ('networked marketers'). Firms in solution $2 \mathrm{~b}$ ('best-in-class') have all dynamic bundles. Firms in solution 3 ('notech networker') have a dynamic networking bundle and lack all technology capabilities. For 'no-tech networkers,' the dynamic international marketing bundle is not relevant for high international performance.

To address asymmetry (Schneider \& Wagemann, 2012), we analyze capability configurations for low international performance. We apply the same raw consistency cut-off (0.80), the proportional reduction in inconsistency cut-off (0.65), and the frequency cut-off ( 1 case) for the truth table. Table 4.7 shows a 
simplified version of the truth table for the capability configurations of low international performance.

Table 4.7 Simplified truth table for Low international performance.

\begin{tabular}{lllllllll}
\hline SIMC & DIMC & STC & DTC & SINC & DINC & $\begin{array}{l}\text { Case } \\
\#\end{array}$ & $\begin{array}{l}\text { Raw } \\
\text { consis. }\end{array}$ & $\begin{array}{l}\text { PRI } \\
\text { consis. }\end{array}$ \\
\hline 0 & 0 & 1 & 1 & 0 & 0 & 2 & 0.92 & 0.73 \\
0 & 0 & 0 & 0 & 0 & 0 & 21 & 0.87 & 0.68 \\
0 & 1 & 1 & 1 & 0 & 0 & 2 & 0.92 & 0.67 \\
0 & 0 & 1 & 1 & 0 & 1 & 2 & 0.91 & 0.66 \\
\hline
\end{tabular}

Notes: SIMC $=$ Substantive international marketing capabilities; DIMC = Dynamic international marketing capabilities; STC $=$ Substantive technological capabilities; DTC $=$ Dynamic technological capabilities; SINC $=$ Substantive international networking capabilities; DINC = Dynamic international networking capabilities.

Results confirm that the set relation between the configurations of conditions and the outcome is also highly consistent: individual solutions consistency is above 0.87 , and the overall consistency is 0.89 . Also, these solutions explain a relatively high proportion of the outcome with total coverage of 0.65 (see Table 4.8).

Table 4.8 Capability configuration for Low international performance.

\begin{tabular}{|c|c|c|c|}
\hline Conditions & \multicolumn{3}{|c|}{ Solutions } \\
\hline & 4 & $5 a$ & $5 b$ \\
\hline $\begin{array}{l}\text { Substantive international marketing } \\
\text { capabilities }\end{array}$ & $\otimes$ & $\otimes$ & $\otimes$ \\
\hline $\begin{array}{l}\text { Dynamic international marketing } \\
\text { capabilities }\end{array}$ & $\otimes$ & & $\otimes$ \\
\hline Substantive technological capabilities & $\otimes$ & 0 & 0 \\
\hline Dynamic technological capabilities & $\otimes$ & 0 & 0 \\
\hline $\begin{array}{l}\text { Substantive international networking } \\
\text { capabilities }\end{array}$ & $\otimes$ & $\otimes$ & $\otimes$ \\
\hline $\begin{array}{l}\text { Dynamic international networking } \\
\text { capabilities }\end{array}$ & $\otimes$ & $\otimes$ & \\
\hline Consistency & 0.87 & 0.92 & 0.92 \\
\hline Raw coverage & 0.53 & 0.38 & 0.38 \\
\hline Unique coverage & 0.25 & 0.03 & 0.04 \\
\hline Overall solution consistency & & 0.89 & \\
\hline Overall solution coverage & & 0.65 & \\
\hline
\end{tabular}

Notes: $=$ core condition present; $\otimes$ = core condition absent; $\otimes$ = peripheral condition absent; blank space $=$ does not care. Consistency cut-off: 0.89 ; frequency cut-off: 1 . 
Firms in solution 4 ('worst-in-class') lack all three dynamic bundles. The unique coverage of solution 4 is higher than for others, which indicates that this solution is the dominant capability configuration for low international performance.

Firms in solutions 5a and 5b ('nerds') are characterized by the dynamic international technology bundle, and the absence of substantive international marketing capabilities and substantive international networking capabilities as core conditions, together with other necessary complementary factors that lead to low international performance. In solutions $5 \mathrm{a}$ and $5 \mathrm{~b}$, the absence of dynamic international networking capabilities and the absence of dynamic international marketing capabilities correspondingly intensify the adverse effects of core conditions. 
Table 4.9 Mean values of condition in each solution.

\begin{tabular}{|c|c|c|c|c|c|c|c|c|}
\hline & & IP & SIMC & DIMC & STC & DTC & SINC & DINC \\
\hline \multirow[t]{10}{*}{ High IP } & Group mean & 4.31* & $4.34 *$ & $4.45 *$ & 4.34 & 4.14* & $4.61 *$ & $4.57 *$ \\
\hline & & 0.35 & 0.42 & 0.44 & 0.45 & 0.70 & 0.29 & 0.31 \\
\hline & Solution 1 & 4.61 & 4.08 & 4.27 & 3.60 & 2.85 & 4.86 & 4.55 \\
\hline & & 0.37 & 0.78 & 0.85 & 0.31 & 0.41 & 0.29 & 0.40 \\
\hline & Solution 2a & 4.31 & 4.51 & 4.62 & 4.46 & 4.40 & 4.64 & 4.64 \\
\hline & & 0.34 & 0.27 & 0.25 & 0.39 & 0.41 & 0.25 & 0.26 \\
\hline & Solution $2 \mathrm{~b}$ & 4.27 & 4.45 & 4.51 & 4.58 & 4.52 & 4.60 & 4.62 \\
\hline & & 0.32 & 0.28 & 0.31 & 0.23 & 0.25 & 0.20 & 0.23 \\
\hline & Solution 3 & 4.00 & 4.16 & 4.44 & 4.08 & 3.88 & 4.39 & 4.50 \\
\hline & & 0.31 & 0.40 & 0.62 & 0.00 & 0.06 & 0.66 & 0.71 \\
\hline \multirow[t]{8}{*}{ Low IP } & Group mean & $2.96 *$ & 3.07* & $3.33 *$ & 3.60 & $3.59 *$ & $3.25^{*}$ & $3.47 *$ \\
\hline & & 0.43 & 0.39 & 0.38 & 0.83 & 0.72 & 0.50 & 0.52 \\
\hline & Solution 4 & 3.10 & 3.16 & 3.24 & 3.21 & 3.24 & 3.20 & 3.34 \\
\hline & & 0.24 & 0.27 & 0.31 & 0.51 & 0.40 & 0.51 & 0.31 \\
\hline & Solution 5a & 2.53 & 3.00 & 3.77 & 4.65 & 4.65 & 3.45 & 3.34 \\
\hline & & 0.21 & 0.55 & 0.42 & 0.37 & 0.27 & 0.56 & 0.47 \\
\hline & Solution $5 \mathrm{~b}$ & 2.58 & 2.80 & 3.38 & 4.87 & 4.65 & 3.39 & 4.08 \\
\hline & & 0.73 & 0.58 & 0.28 & 0.27 & 0.22 & 0.47 & 0.91 \\
\hline
\end{tabular}

Notes: Italics are the standard deviations. IP = International performance; SIMC = Substantive international marketing capabilities; DIMC = Dynamic international marketing capabilities; STC $=$ Substantive technological capabilities; DTC $=$ Dynamic technological capabilities; SINC $=$ Substantive international networking capabilities; DINC = Dynamic international networking capabilities.; * difference between High IP and Low IP significant at a level of 0.05 . 


\subsection{Discussion}

\subsubsection{Discussing the results for the CBP}

For the CBP, this study implies that dynamic bundles exist and are related to performance differences: We show that in the high-performing group, 9 out of 12 bundles are jointly present or absent. In the low-performing group, 7 out of 9 bundles are jointly absent or present. This finding supports the CBP-stream that argues that neither SC nor DC have an independent, but rather an interdependent relation to firm performance.

Methodologically, we have argued that the foundations of the set-theoretic approach mirror key findings of the CBP (conjunction, equifinality, asymmetry). Evidence supporting conjunction is that, in all solutions, several bundles or their absence are at play. Evidence to support equifinality showed that more than one configuration is related to high international performance. Evidence supporting asymmetry showed that technology capabilities are related to one of the highperforming and several of the low-performing groups.

This congruence between method and object of analysis makes set-theoretic approaches a suitable tool for research on capabilities. Set-theoretic analyses of capabilities can complement previous work on dynamic bundles, such as Walecheck et al. (2019), who used an interaction logic, and Weerawardena et al. (2019), who used small-n qualitative studies.

\subsubsection{Discussing implications for international entrepreneurship}

Marketing, technology, and networking capabilities appear in bundles that can be elements in high-performing configurations. Each configuration is a distinct type of TBEIF. Two of the configurations are not surprising (2, 'best-in-class' and 4, 'worst-in-class'). Others, such as solution 1 ('established marketers'), 2 ('networked marketers'), 4 ('no-tech networker'), and 5a and 5b ('nerds') have patterns that go beyond the linear, independent capability-performance relationship of prior research.

A relevant question about those new patterns concerns the unexpected role of the dynamic technology bundle. A group of well-performing firms has a low degree of technological capabilities, and a group of low-performing TBEIFs has a high 
degree of a technology capability bundle. One reason for the inverse relationship between the technology bundle and performance may be that some firms that are low on the technology capability bundle have a strong international partner. An in-depth investigation of firms in solution 1 ('established marketers') demonstrates their heavy reliance on one partner for their international business. Their superior networking capabilities allow them to build solid partnerships with their primary partners. In combination with their marketing capabilities, this circumvents the need to have superior technology capabilities (Mort \& Weerawardena, 2006).

Second, an in-depth investigation of firms $5 \mathrm{a}$ and $5 \mathrm{~b}$ ('nerds' that score high on the technology capabilities, but low on performance) shows that 'nerds' score low on international experience. Therefore, they may underestimate the marketing and networking aspect of the business and, hence, underinvest in it: previous studies suggest that the capability to meet customer requirements (e.g., marketing capabilities) are more important than unique products for the success of high-tech ventures (Berry, 1996; Kakati, 2003).

\subsubsection{Managerial relevance}

We offer three managerial insights. First, there is no 'one best way' for TBEIFs to succeed, as various routes are possible. Founders can analyze their current strengths and weaknesses. This analysis allows them to determine the configuration type to which they belong or the configuration type that they can most easily achieve. They can then invest in those capabilities that will most effectively bring them to a high-performing configuration.

Second, TBEIFs need to combine SCs and DCs of the same kind to build dynamic bundles. Such a combination can be path-dependent in that startup-team complementarities in terms of SC endowments and sense-making as a process of DC emergence will transform the initial set of SCs. Thus, team building and sense-making can provide a mechanism to create and align dynamic bundles (Weerawardena et al., 2019).

Third, international entrepreneurs may remember that a focus on technological capabilities to the neglect of international marketing, and networking capabilities are a recipe for low international performance. The general entrepreneurship literature highlights the importance of early knowledge generation from external sources, even before the technology has been developed (Harms \& Schwery, 
2020). This international entrepreneurship literature underscores the importance of networks or early internationalization (Weerawardena et al., 2019). Therefore, we advise managers to invest more resources in marketing and networking and to build corresponding dynamic bundles. Technology entrepreneurs face the challenge of how to develop a different set of capabilities than they currently use. Stabilizing forces such as inertia (Hannan \& Freeman, 1984), institutionalization (DiMaggio \& Powell, 1983), or sticky mental models (Wood, McKelvie, \& Haynie, 2014) may keep entrepreneurs from radical change.

\subsection{Limitation and future study}

This study's' limitations are avenues for future research. First, its generalizability is limited because it is based on data from one country. Further research can replicate our study in a multi-country comparison (Franke \& Richey, 2010). For example, a comparative study can show whether and how capability configurations vary among firms in emerging countries or how they differ from firms in developed countries. Comparative studies on countries and industries would help to chart the limits of generalizability. Such studies would have to address sample size. While ours is a 'large-n' fsQCA study (Greckhamer et al., 2013), and the sample selected can claim theoretical generalizability, our study is not geared towards making statistically generalizable statements (Thomann \& Maggetti, 2017).

Second, our analysis does not model the temporal relationships. For example, longitudinal data could support causality between dynamic bundles and performance. Also, process studies could model the interaction between dynamic bundles. Third, although the survey was designed to counter assimilation effects (Van de Walle \& Van Ryzin, 2011), the high correlation between the constructs suggests that respondents may find difficulty in distinguishing the concepts. Therefore, further evidence on the discriminant validity between substantive and dynamic capabilities is needed. Future research should address these limitations. 


\section{References}

Al-Aali, A., \& Teece, D. J. (2014). International Entrepreneurship and the Theory of the (Long-Lived) International Firm: A Capabilities Perspective. Entrepreneurship Theory and Practice, 38(1), 95-116. doi:10.1111/etap.12077

Autio, E., George, G., \& Alexy, O. (2011). International entrepreneurship and capability development - Qualitative evidence and future research directions. Entrepreneurship Theory and Practice, 35(1), 11-37. doi:https://doi.org/10.1111/j.1540-6520.2010.00421.x

Baum, M., Schwens, C., \& Kabst, R. (2011). A typology of international new ventures: Empirical evidence from high-technology industries. Journal of Small Business Management, 49(3), 305-330. doi:10.1111/j.1540-627X.2011.00328.x

Berg-Schlosser, D., De Meur, G., Rihoux, B., \& Ragin, C. C. (2009). Qualitative comparative analysis (QCA) as an approach. In B. Rihoux \& C. C. Ragin (Eds.), Configurational Comparative Methods: Qualitative Comparative Analysis (QCA) and related techniques (pp. 1-18). Thousand Oaks and London: Sage.

Berry, M. M. J. (1996). Technical entrepreneurship, strategic awareness and corporate transformation in small high-tech firms. Technovation, 16(9), 487-522. doi:https://doi.org/10.1016/0166-4972(96)00056-9

Beynon, M., Jones, P., \& Pickernell, D. (2016). Country-level investigation of innovation investment in manufacturing: Paired fsQCA of two models. Journal of Business Research, 69(11), 5401-5407. doi:https://doi.org/10.1016/j.jbusres.2016.04.145

Bonner, J. M., Kim, D., \& Cavusgil, S. T. (2005). Self-perceived strategic network identity and its effects on market performance in alliance relationships. Journal of Business Research, 58(10), 1371-1380. doi:10.1016/j.jbusres.2004.07.002

Bruni, D. S., \& Verona, G. (2009). Dynamic marketing capabilities in science-based firms: An exploratory investigation of the pharmaceutical industry. British Journal of Management, 20(SUPP. 1), S101-S117. doi:10.1111/j.14678551.2008.00615.x

Chang, S.-J., van Witteloostuijn, A., \& Eden, L. (2010). From the Editors: Common method variance in international business research. Journal of International Business Studies, 41(2), 178-184. doi:10.1057/jibs.2009.88

Chen, X., Zou, H., \& Wang, D. T. (2009). How do new ventures grow? Firm capabilities, growth strategies and performance. International Journal of Research in Marketing, 26(4), 294-303. doi:https://doi.org/10.1016/j.ijresmar.2009.08.004

Chin, T., Liu, R.-H., \& Yang, X. (2015). Reverse internationalization in Chinese firms: A study of how global startup OEMs seek to compete domestically. Asia Pacific Business Review, 22(2), 201-219. 
Collis, D. J. (1996). Organizational capability as a source of profit. In B. Moingeon \& A. Edmondson (Eds.), Organizational Learning and Competitive Advantage (pp. 139-163). London: SAGE Publications.

Coviello, N., \& Yli-Renko, H. (2016). Handbook of measures for international entrepreneurship research: Multi-item scales crossing disciplines and contexts: Edward Elgar Publishing.

Danneels, E. (2002). The dynamics of product innovation and firm competences. Strategic Management Journal, 23(12), 1095-1121. doi:10.1002/smj.275

De Clercq, D., Sapienza, H. J., Yavuz, R. I., \& Zhou, L. (2012). Learning and knowledge in early internationalization research: Past accomplishments and future directions. Journal of Business Venturing, 27(1), 143-165. doi:https://doi.org/10.1016/j.jbusvent.2011.09.003

De Clercq, D., \& Zhou, L. (2014). Entrepreneurial strategic posture and performance in foreign markets: The critical role of international learning effort. Journal of International Marketing, 22(2), 47-67. doi:10.1509/jim.13.0131

DeVellis, R. F. (2016). Scale development: Theory and applications (Vol. 26): Sage publications.

Di Stefano, G., Peteraf, M., \& Verona, G. (2014). The organizational drivetrain: A road to integration of dynamic capabilities research. Academy of Management Perspectives, 28(4), 307-327. doi:10.5465/amp.2013.0100

DiMaggio, P. J., \& Powell, W. W. (1983). The Iron Cage Revisited: Institutional Isomorphism and Collective Rationality in Organisational Fields. American Sociological Review, 48(2), 147-160.

Efrat, K., \& Shoham, A. (2012). Born global firms: The differences between their shortand long-term performance drivers. Journal of World Business, 47(4), 675-685. doi:https://doi.org/10.1016/j.jwb.2012.01.015

Eisenhardt, K. M., \& Martin, J. A. (2000). Dynamic capabilities: What are they? Strategic Management Journal, 21(10-11), 1105-1121. doi:https://doi.org/10.1002/1097-0266(200010/11)21:10/11<1105::AID-

SMJ133>3.0.CO;2-E

Ennen, E., \& Richter, A. (2010). The whole is more than the sum of its parts - or is it? A review of the empirical literature on complementarities in organizations. Journal of Management, 36(1), 207-233.

Fainshmidt, S., Pezeshkan, A., Lance Frazier, M., Nair, A., \& Markowski, E. (2016). Dynamic capabilities and organizational performance: a meta-analytic evaluation and extension. Journal of Management Studies, 53(8), 1348-1380.

Fainshmidt, S., Wenger, L., Pezeshkan, A., \& Mallon, M. R. (2019). When do dynamic capabilities lead to competitive advantage? The importance of strategic fit. Journal of Management Studies, 56(4), 758-787. doi:10.1111/joms.12415 
Fischer, M., \& Maggetti, M. (2017). Qualitative Comparative Analysis and the study of policy processes. Journal of Comparative Policy Analysis: Research and Practice, 19(4), 345-361.

Fiss, P. C. (2011). Building better causal theories: A fuzzy set approach to typologies in organization research. Academy of Management Journal, 54(2), 393-420. doi:https://doi.org/10.5465/amj.2011.60263120

Flatten, T. C., Engelen, A., Zahra, S. A., \& Brettel, M. (2011). A measure of absorptive capacity: Scale development and validation. European Management Journal, 29(2), 98-116. doi:https://doi.org/10.1016/j.emj.2010.11.002

Flor, M., \& Oltra, M. J. (2005). The influence of firms' technological capabilities on export performance in supplier-dominated industries: The case of ceramic tiles firms. $\quad R \& D$ Management, 35(3), 333-347. doi:10.1111/j.14679310.2005.00393.x

Foreign-Investment-Promotion-Bureau. (2019, 2019-01-31). Xi'an High-Tech Industries Development Zone. Retrieved from http://en.xa.gov.cn/business/settingupabusi/949.htm

Fowler, S. W., King, A. W., Marsh, S. J., \& Victor, B. (2000). Beyond products: new strategic imperatives for developing competencies in dynamic environments. Journal of Engineering and Technology Management, 17(3-4), 357-377.

Franke, G. R., \& Richey, R. G. (2010). Improving generalizations from multi-country comparisons in international business research. Journal of International Business Studies, 41(8), 1275-1293. doi:10.1057/jibs.2010.21

Gabrielsson, P., \& Gabrielsson, M. (2013). A dynamic model of growth phases and survival in international business-to-business new ventures: The moderating effect of decision-making logic. Industrial Marketing Management, 42(8), 1357-1373.

Ganster, D. C., Hennessey, H. W., \& Luthans, F. (1983). Social desirability response effects: Three alternative models. Academy of Management Journal, 26(2), 321-331.

Gelhard, C., von Delft, S., \& Gudergan, S. P. (2016). Heterogeneity in dynamic capability configurations: Equifinality and strategic performance. Journal of Business $\quad$ Research, 69(11), 5272-5279. doi:https://doi.org/10.1016/j.jbusres.2016.04.124

Gerschewski, S., Rose, E. L., \& Lindsay, V. J. (2015). Understanding the drivers of international performance for born global firms: An integrated perspective. Journal of World Business, 50(3), 558-575.

Gerschewski, S., \& Xiao, S. S. (2015). Beyond financial indicators: An assessment of the measurement of performance for international new ventures. International Business Review, 24(4), 615-629.

Goodman, L. A. (1961). Snowball sampling. The Annals of Mathematical Statistics, 32(1), 148-170. 
Greckhamer, T. (2016). CEO compensation in relation to worker compensation across countries: The configurational impact of country-level institutions. Strategic Management Journal, 37(4), 793-815. doi:10.1002/smj.2370

Greckhamer, T., Furnari, S., Fiss, P. C., \& Aguilera, R. V. (2018). Studying configurations with qualitative comparative analysis: Best practices in strategy and organization research. Strategic Organization, 16(4), 482-495. doi:10.1177/1476127018786487

Greckhamer, T., Misangyi, V. F., \& Fiss, P. C. (2013). The two QCAs: From a small-N to a large-N set theoretic approach. In P. C. Fiss, B. Cambré, \& A. Marx (Eds.), Configurational Theory and Methods in Organizational Research - Research in the Sociology of Organizations (pp. 49-75): Emerald.

Greenwald, A. G. (2012). There is nothing so theoretical as a good method. Perspectives on Psychological Science, 7(2), 99-108.

Hannan, M. T., \& Freeman, J. (1984). Structural inertia and organizational change. American Sociological Review, 49(4), 149-164.

Harms, R., \& Schwery, M. (2020). Lean startup: Operationalizing lean startup capability and testing its performance implications. Journal of Small Business Management, 58(1), 200-223. doi:10.1080/00472778.2019.1659677

Heimeriks, K. H., Schijven, M., \& Gates, S. (2012). Manifestations of higher-order routines: The underlying mechanisms of deliberate learning in the context of postacquisition integration. Academy of Management Journal, 55(3), 703-726.

Helfat, C. E. (2007). Dynamic capabilities: Foundations. In C. E. Helfat, S. Finkelstein, W. Mitchell, M. Peteraf, H. Singh, D. Teece, \& S. G. Winter (Eds.), Dynamic Capabilities: Understanding Strategic Change in Organizations (pp. 1-18). London: Blackwell Publishing Ltd.

Helfat, C. E., \& Peteraf, M. A. (2003). The dynamic resource-based view: Capability lifecycles. Strategic Management Journal, 24(10), 997-1010. doi:https://doi.org/10.1002/smj.332

Hitt, M. A., Dacin, M. T., Levitas, E., Arregle, J.-L., \& Borza, A. (2000). Partner selection in emerging and developed market contexts: Resource-based and organizational learning perspectives. Academy of Management Journal, 43(3), 449-467.

Isobe, T., Makino, S., \& Montgomery, D. B. (2008). Technological capabilities and firm performance: The case of small manufacturing firms in Japan. Asia Pacific Journal of Management, 25(3), 413-428. doi:10.1007/s10490-008-9098-z

Jantunen, A., Tarkiainen, A., Chari, S., \& Oghazi, P. (2018). Dynamic capabilities, operational changes, and performance outcomes in the media industry. Journal of Business Research, 89( ), 251-257. doi:10.1016/j.jbusres.2018.01.037

Jie, S., \& Harms, R. (2018). Capabilities and international startups' international performance. A systematic literature review. Paper presented at the Academy of Management Conference, Chicago. 
Kakati, M. (2003). Success criteria in high-tech new ventures. Technovation, 23(5), 447457. doi:https://doi.org/10.1016/S0166-4972(02)00014-7

Karna, A., Richter, A., \& Riesenkampff, E. (2016). Revisiting the role of the environment in the capabilities-financial performance relationship: A metaanalysis. Strategic Management Journal, 37(6), 1154-1173.

Katz, D., \& Kahn, R. L. (1978). The social psychology of organizations (Vol. 2): Wiley New York.

Keupp, M. M., \& Gassmann, O. (2009). The past and the future of international entrepreneurship: a review and suggestions for developing the field. Journal of Management, 35(3), 600-633.

Knight, G., \& Cavusgil, S. T. (2004). Innovation, organizational capabilities, and the born-global firm. Journal of International Business Studies, 35(2), 124-141.

Lee, C., Lee, K., \& Pennings, J. M. (2001). Internal capabilities, external networks, and performance: A study on technology-based ventures. Strategic Management Journal, 22(6-7), 615-640. doi:10.1002/smj.181

Li, C., He, C., \& Lin, C. (2018). Economic impacts of the possible China-US trade war. Emerging Markets Finance and Trade, 54(7), 1557-1577. doi:10.1080/1540496X.2018.1446131

Lichtenstein, B. M. B., \& Brush, C. G. (2001). How do "resource bundles" develop and change in new ventures? A dynamic model and longitudinal exploration. Entrepreneurship Theory and Practice, 25(3), 37-58.

Lichtenthaler, U., \& Muethel, M. (2012a). The impact of family involvement on dynamic innovation capabilities: Evidence from German manufacturing firms. Entrepreneurship Theory and Practice, 36(6), 1235-1253. doi:10.1111/j.15406520.2012.00548.x

Lichtenthaler, U., \& Muethel, M. (2012b). Retracted: The impact of family involvement on dynamic innovation capabilities: Evidence from German manufacturing firms. Entrepreneurship Theory and Practice, 36(6), 1235-1253. doi:10.1111/j.1540-6520.2012.00548.x

Lisboa, A., Skarmeas, D., \& Saridakis, C. (2016). Entrepreneurial orientation pathways to performance: A fuzzy-set analysis. Journal of Business Research, 69(4), 1319-1324. doi:10.1016/j.jbusres.2015.10.099

Martin, S. L., \& Javalgi, R. G. (2016). Entrepreneurial orientation, marketing capabilities and performance: The Moderating role of Competitive Intensity on Latin American International New Ventures. Journal of Business Research, 69(6), 2040-2051. doi:10.1016/j.jbusres.2015.10.149

Martin, S. L., Javalgi, R. G., \& Cavusgil, E. (2017). Marketing capabilities, positional advantage, and performance of born global firms: Contingent effect of ambidextrous innovation. International Business Review, 26(3), 527-543. doi:https://doi.org/10.1016/j.ibusrev.2016.11.006 
Menguc, B., Auh, S., \& Yannopoulos, P. (2014). Customer and supplier involvement in design: The moderating role of incremental and radical innovation capability. Journal of Product Innovation Management, 31(2), 313-328. doi:10.1111/jpim.12097

Meyer, A. D., Tsui, A. S., \& Hinings, C. R. (1993). Configurational approaches to organizational analysis. Academy of Management Journal, 36(6), 1175-1195.

Mintzberg, H. (1980). Structure in 5's: A synthesis of the research on organization design. Management Science, 26(3), 322-341.

Misangyi, V. F., Greckhamer, T., Furnari, S., Fiss, P. C., Crilly, D., \& Aguilera, R. V. (2017). Embracing causal complexity: the emergence of a neo-configurational perspective. Journal of Management, 43(1), 255 -282.

Mitrega, M., Forkmann, S., Zaefarian, G., \& Henneberg, S. C. (2017). Networking capability in supplier relationships and its impact on product innovation and firm performance. International Journal of Operations and Production Management, 37(5), 577-606. doi:10.1108/IJOPM-11-2014-0517

Morgan, N. A. (2012). Marketing and business performance. Journal of the Academy of Marketing Science, 40(1), 102-119. doi:10.1007/s11747-011-0279-9

Morgan, N. A., Vorhies, D. W., \& Mason, C. H. (2009). Research notes and commentaries market orientation: Marketing capabilities, and firm performance. Strategic Management Journal, 30(8), 909-920. doi:10.1002/smj.764

Mort, G. S., \& Weerawardena, J. (2006). Networking capability and international entrepreneurship: How networks function in Australian born global firms. International Marketing $\quad$ Review, 23(5), 549-572. doi:10.1108/02651330610703445

Muñoz, P., \& Kibler, E. (2016). Institutional complexity and social entrepreneurship: A fuzzy-set approach. Journal of Business Research, 69(4), 1314-1318. doi:10.1016/j.jbusres.2015.10.098

Parida, V., Pemartín, M., \& Frishammar, J. (2009). The impact of networking practices on small firm innovativeness and performance: A multivariate approach. International Journal of Technoentrepreneurship, 2(2), 115-133. doi:10.1504/IJTE.2009.031500

Peng, D. X., Schroeder, R. G., \& Shah, R. (2008). Linking routines to operations capabilities: A new perspective. Journal of Operations Management, 26(6), 730-748.

Perényi, Á., \& Losoncz, M. (2018). A systematic review of international entrepreneurship special issue articles. Sustainability, 10, 3476. doi:10.3390/su10103476

Peteraf, M. A., Di Stefano, G., \& Verona, G. (2013). The elephant in the room of dynamic capabilities: Bringing two diverging conversations together. Strategic Management Journal, 34(12), 1389-1410. 
Pittaway, L., Robertson, M., Munir, K., Denyer, D., \& Neely, A. (2004). Networking and innovation: a systematic review of the evidence. International Journal of Management Reviews, 5-6(3-4), 137-168. doi:10.1111/j.14608545.2004.00101.X

Protogerou, A., Caloghirou, Y., \& Lioukas, S. (2012). Dynamic capabilities and their indirect impact on firm performance. Industrial and Corporate Change, 21(3), 615-647. doi:10.1093/icc/dtr049

Ragin, C. C. (2009). Redesigning Social Inquiry: Fuzzy Sets and Beyond. London: University of Chicago Press.

Reichert, F. M., Torugsa, N. A., Zawislak, P. A., \& Arundel, A. (2016). Exploring innovation success recipes in low-technology firms using fuzzy-set QCA. Journal of Business Research, 69(11), 5437-5441. doi:https://doi.org/10.1016/i.jbusres.2016.04.151

Rialp, A., Rialp, J., \& Knight, G. A. (2005). The phenomenon of early internationalizing firms: What do we know after a decade (1993-2003) of scientific inquiry? International Business Review, 14(2), 147-166. doi:https://doi.org/10.1016/j.ibusrev.2004.04.006

Rihoux, B., \& Ragin, C. C. (2009a). Configurational comparative methods: Qualitative comparative analysis (QCA) and related techniques. California: SAGE Publications, Inc.

Rihoux, B., \& Ragin, C. C. (2009b). Qualitative comparative analysis using fuzzy sets (fsQCA). In B. Rihoux \& C. C. Ragin (Eds.), Configurational Comparative Methods: Qualitative Comparative Analysis (QCA) and Related Techniques (pp. 87-121). California: SAGE Publications, Inc.

Ripollés, M., \& Blesa, A. (2012). International new ventures as "small multinationals": The importance of marketing capabilities. Journal of World Business, 47(2), 277-287. doi:10.1016/j.jwb.2011.04.015

Romanello, R., \& Chiarvesio, M. (2019). Early internationalizing firms: 2004-2018. Journal of International Entrepreneurship, 17(2), 172-219. doi:10.1007/s10843-018-0241-8

Schilke, O., Hu, S., \& Helfat, C. E. (2017). Quo vadis, dynamic capabilities? A contentanalytic review of the current state of knowledge and recommendations for future research. Academy of Management Annals, 12(1), 390-439. doi:10.5465/annals.2016.0014

Schneider, C. Q., \& Wagemann, C. (2012). Set-theoretic methods for the social sciences: A guide to qualitative comparative analysis: Cambridge University Press.

Schreier, M. (2018). Sampling and Generalization. In U. Flick (Ed.), The SAGE Handbook of Qualitative Data Collection. London: SAGE Publications Ltd.

Seyed Kalali, N., \& Heidari, A. (2016). How was competitive advantage sustained in management consultancies during change: The role of dynamic capabilities. 
Journal of Organizational Change Management, 29(5), 661-685. doi:10.1108/JOCM-10-2015-0188

Sjödin, D. R., Parida, V., \& Kohtamäki, M. (2016). Capability configurations for advanced service offerings in manufacturing firms: Using fuzzy set qualitative comparative analysis. Journal of Business Research, 69(11), 5330-5335.

Song, M., Droge, C., Hanvanich, S., \& Calantone, R. (2005). Marketing and technology resource complementarity: An analysis of their interaction effect in two environmental contexts. Strategic Management Journal, 26(3), 259-276.

Su, Z., Peng, J., Shen, H., \& Xiao, T. (2013). Technological capability, marketing capability, and firm performance in turbulent conditions. Management and Organization Review, 9(1), 115-137. doi:10.1111/j.1740-8784.2011.00280.x

Tan, Q., \& Sousa, C. M. P. (2015). Leveraging marketing capabilities into competitive advantage and export performance. International Marketing Review, 32(1), 78102. doi:10.1108/IMR-12-2013-0279

Teece, D. J. (2007). Explicating dynamic capabilities: The nature and microfoundations of (sustainable) enterprise performance. Strategic Management Journal, 28(13), 1319-1350. doi:10.1002/smj.640

Teece, D. J. (2012). Dynamic capabilities: Routines versus entrepreneurial action. Journal of Management Studies, 49(8), 1395-1401.

Teece, D. J. (2014). The foundations of enterprise performance: Dynamic and ordinary capabilities in an (economic) theory of firms. Academy of Management Perspectives, 28(4), 328-352. doi:10.5465/amp.2013.0116

Teece, D. J., Pisano, G., \& Shuen, A. (1997). Dynamic capabilities and strategic management. Strategic Management Journal, 18(7), 509-533.

Thomann, E., \& Maggetti, M. (2017). Designing research with qualitative comparative analysis (QCA): Approaches, challenges, tools. Sociological Methods \& Research.

Tse, E. (2016). China's Disruptors: How Alibaba, Xiaomi, Tencent, and Other Companies are Changing the Rules of Business: Penguin.

Tzokas, N., Kim, Y. A., Akbar, H., \& Al-Dajani, H. (2015). Absorptive capacity and performance: The role of customer relationship and technological capabilities in high-tech SMEs. Industrial Marketing Management, 47, 134-142. doi:10.1016/j.indmarman.2015.02.033

Van de Walle, S., \& Van Ryzin, G. G. (2011). The order of questions in a survey on citizen satisfaction with public services: Lessons from a split-ballot experiment. Public Administration, 89(4), 1436-1450.

Vorhies, D. W., \& Morgan, N. A. (2005). Benchmarking marketing capabilities for sustainable competitive advantage. Journal of Marketing, 69(1), 80-94. doi:10.1509/jmkg.69.1.80.55505 
Vorhies, D. W., Morgan, R. E., \& Autry, C. W. (2009). Product-market strategy and the marketing capabilities of the firm: Impact on market effectiveness and cash flow performance. Strategic Management Journal, 30(12), 1310-1334.

Vorhies, D. W., Orr, L. M., \& Bush, V. D. (2011). Improving customer-focused marketing capabilities and firm financial performance via marketing exploration and exploitation. Journal of the Academy of Marketing Science, 39(5), 736-756. doi:10.1007/s11747-010-0228-z

Walcott, S. M. (2003). Xi'an as an inner China development model. Eurasian Geography and Economics, 44(8), 623-640. doi:10.2747/1538-7216.44.8.623

Waleczek, P., von den Driesch, T., Flatten, T. C., \& Brettel, M. (2019). On the dynamic bundles behind operations management and research and development. European Management Journal, 37(2), 175-187. doi:https://doi.org/10.1016/j.emj.2018.03.005

Walter, A., Auer, M., \& Ritter, T. (2006). The impact of network capabilities and entrepreneurial orientation on university spin-off performance. Journal of Business Venturing, 21(4), 541-567. doi:https://doi.org/10.1016/j.jbusvent.2005.02.005

Wang, Z., \& Kim, H. G. (2017). Can social media marketing improve customer relationship capabilities and firm performance? Dynamic capability perspective. Journal of Interactive Marketing, 39, 15-26. doi:https://doi.org/10.1016/j.intmar.2017.02.004

Weerawardena, J., Mort, G. S., \& Liesch, P. W. (2019). Capabilities development and deployment activities in born global B-to-B firms for early entry into international markets. Industrial Marketing Management, 78, 122-136. doi:10.1016/j.indmarman.2017.06.004

Winter, S. G. (2003). Understanding dynamic capabilities. Strategic Management Journal, 24(10), 991-995.

Wood, M. S., McKelvie, A., \& Haynie, J. M. (2014). Making it personal: Opportunity individuation and the shaping of opportunity beliefs. Journal of Business Venturing, 29(2), 252-272.

Woodside, A. G. (2013). Moving beyond multiple regression analysis to algorithms: Calling for adoption of a paradigm shift from symmetric to asymmetric thinking in data analysis and crafting theory. Journal of Business Research, 66(4), 463472. doi:https://doi.org/10.1016/j.jbusres.2012.12.021

Yang, Z., Huang, Z., Wang, F., \& Feng, C. (2018). The double-edged sword of networking: Complementary and substitutive effects of networking capability in China. Industrial Marketing Management, 68, 145-155. doi:10.1016/j.indmarman.2017.10.010

Zhang, M., Sarker, S., \& Sarker, S. (2013). Drivers and export performance impacts of IT capability in 'born-global' firms: A cross-national study. Information Systems Journal, 23(5), 419-443. 
Zhang, M., \& Tansuhaj, P. S. (2007). Organizational culture, information technology capability, and performance: The case of born global firms. Multinational Business Review, 15(3), 43-78. doi:10.1108/1525383x200700012

Zhou, L., Wu, A., \& Barnes, B. R. (2012). The effects of early internationalization on performance outcomes in young international ventures: The mediating role of marketing capabilities. Journal of International Marketing, 20(4), 25-45. doi:10.1509/jim.12.0076

Zollo, M., \& Winter, S. G. (2002). Deliberate learning and the evolution of dynamic capabilities. Organization Science, 13(3), 339-351. 


\section{CHAPTER 5 \\ Cross-cultural Competences and International Entrepreneurial Intention: A Study on Entrepreneurship Education}

This chapter has been published as:

Jie, S., \& Harms, R. (2017). Cross-cultural competences and international entrepreneurial intention: A study on entrepreneurship education. Education Research International, 2017, 12. doi:10.1155/2017/9042132. 


\section{$5.1 \quad$ Introduction}

Entrepreneurship education has been acknowledged as an effective way to develop students' entrepreneurial intention (Pittaway \& Cope, 2007). With increasing recognition of the importance of international entrepreneurship, entrepreneurship educators may also want to strengthen students' international entrepreneurial intention (IEI). International entrepreneurship (IE) is defined as "the discovery, enactment, evaluation, and exploitation of opportunities - across national borders - to create future goods and service" (Oviatt \& McDougall, 2005, p. 7). IE is playing an important role in countries' economic development. For example, Eurofund revealed that around $20 \%$ of the young enterprises in Europe are born globals (Parent-Thirion et al., 2012). These new startups contributed significantly to job creation and welfare in Europe (Mets, 2014). According to McKinsey, 86\% of tech-based start-ups are "born global" in the USA (Manyika et al., 2016), and 360 million people are now engaging in cross border ecommerce worldwide (Manyika et al., 2016). Therefore, to identify and to support students who intend to expand their entrepreneurial activities internationally is a key goal for entrepreneurship education.

The Theory of Planned Behavior (TPB; Ajzen, 1985; Ajzen, 1991) argues that entrepreneurial intention is an effective predictor for entrepreneurial behavior (Yang, 2013). The central tenet of TPB (Souitaris, Zerbinati, \& Al-Laham, 2007) is that planned behaviors (such as international entrepreneurship) are intentional and can be predicted by intention towards that behavior (Kautonen, van Gelderen, \& Fink, 2015). Prior studies have confirmed the validity of TPB in predicting entrepreneurial intention (EI; Van Gelderen et al., 2008). For example, Van Gelderen et al. (2008) reported that TPB can explain 38\% of the variance of EI. With regard to IEI, Sommer (2013) showed that there is a positive relationship (path coefficient of .32) between IE Self-efficacy and IEI.

Previous research has shown that international entrepreneurs need to deal with numerous cross-cultural issues (Crick, 2009). Hence, cross-cultural competence is a critical driver of international performance (Nummela, Saarenketo, \& Puumalainen, 2004). Two main cross-cultural competences (Andresen \& Bergdolt, 2017) are cultural intelligence (CQ), and global mindset (GM). Both are regarded as prerequisites for intentions and success in the international business context (Lovvorn \& Chen, 2011; Maznevski \& Lane, 2004). For 
example, compared to entrepreneurs that have a low degree of cross-cultural competences, highly cross-culturally competent entrepreneurs perform better at identifying international business opportunities (Muzychenko, 2008).

CQ is person's "capability for successful adaptation to new cultural settings, that is, for unfamiliar settings attributable to cultural contexts" (Earley, Ang, \& Tan, 2006, p. 5). CQ enables individuals to conduct appropriate behavior in foreign cultural contexts (Earley, 2002). Such behaviors lower the risk of business activities in new cultures. A lower risk could trigger individuals' intention to engage in international entrepreneurship. GM is a mindset that "combines an openness to and awareness of diversity across cultures and markets with a propensity and ability to synthesize across this diversity" (Gupta \& Govindarajan, 2002, p. 117). GM strengthens individuals' willingness to take risks (Kark \& Van Dijk, 2007). With such willingness, individuals would be more likely to engage in IE activities. Also, GM raises global entrepreneurs' alertness to diversity and fosters creative thinking (Chandwani, Agrawal, \& Kedia, 2016).

We believe that TPB-based models on IEI can profit from an integration of the cultural competence literature (Brislin, Worthley, \& Macnab, 2006; Sommer, 2013). TPB addresses the link between intention and attitude, subjective norms, and perceived behavioral control. The strength of these links may be enhanced by CQ and GM (Janssens \& Brett, 2006). Second, a combination of both CQ and GM in one model is warranted, as both constructs overlap, yet also differ in key aspects (Maznevski \& Lane, 2004). For example, CQ focuses on the behavioral ability to interact interpersonally, and GM stresses awareness and integration of diversity across cultures (Earley, Murnieks, \& Mosakowski, 2007). Third, CQ and GM may be related directly to IEI. Hence, to derive at a more complete explanation and counter issues of missing variable bias, an integration of cultural competences into the TPB-model is warranted.

This study integrates CQ, GM, and the standard TPB model to identify the drivers of students' IEI. The study's objectives are: (1) identify whether GM and CQ could lead to IEI directly; (2) evaluate the possible moderating influence of GM and CQ on TPB-elements to IEI; and (3) assess the effect of the same factors on EI (instead of IEI) to show whether the effects of CQ and GM are unique for IEI rather than both IEI and EI. Doing so contributes to the international entrepreneurship literature by exploring drivers of IEI. In addition, this study provides indications for universities' entrepreneurship education programs on how to strengthen students' IEI. 


\section{$5.2 \quad$ Theory and hypotheses}

\subsubsection{TPB and (international) entrepreneurial intention}

TPB postulates three conceptually independent determinants of entrepreneurial intention, the "self-acknowledged conviction by a person that they intend to set up a new business venture and consciously plan to do so at some point in the future" (Thompson, 2009, p. 676). The first determinant is the attitude towards the behavior, which refers to the extent of an individual's positive evaluation of IE. It reflects the desirability of engaging in IEI activities. A positive personal attitude towards IE indicates that the respondent is more in favor of engaging in IEI activities than in other career paths (Kolvereid, 1996). The second predictor is 'subjective norms'. It refers to the perceived opinions from social reference groups (such as family members and friends) regarding whether the individual should perform IE. Given highly supportive subjective norms from surrounding important people, individual would feel encouraged to engage in IE. The third antecedent is the level of perceived behavioral control (PBC), which refers to the perceived ease of performing a particular behavior (Ajzen, 2002). PBC reflects the perceived ability to become an international entrepreneur (Kolvereid, 1996). People who perceive to be more capable to perform international entrepreneurship activities are more likely to engage in them than in other career paths.

We expect that individuals with a positive personal attitude, subjective norms and perceived behavioral control would be more likely to have intentions to engage in international entrepreneurship. Formally:

Hypothesis 1: The higher the degree of personal attitudes, the higher the international entrepreneurial intention.

Hypothesis 2: The higher the degree of subjective norms, the higher the international entrepreneurial intention.

Hypothesis 3: The higher the degree of perceived behavioral control, the higher the international entrepreneurial intention. 


\subsubsection{Cultural intelligence and IEI}

CQ is defined as "a person's capability for successful adaptation to new cultural settings, that is, for unfamiliar settings attributable to cultural contexts" (Earley et al., 2006, p. 5). It consists of four facets: a cognitive facet, a motivational facet, a behavioral facet, and a process facet (Earley et al., 2007).

The cognitive facet of CQ is embodied in one's own personality, social identity, and social roles. It refers to an individual's capability to adapt effectively to new cultural contexts. The cognitive facet contains three critical elements. First is the cognitive flexibility, which means a constant reshaping and adaptation of the self when operating within a new cultural setting. Second is the reorganization capability to reformulate one's self-concept in new situations. Third are strong reasoning skills, which help to understand reasons behind phenomena in new cultures. In the global market, high CQ individuals find it easier to understand the foreign environment, acquire market knowledge, reshape their own cognitions, and to recognize opportunities. All this allows an entrepreneur to choose an effective product-market fit (Charoensukmongkol, 2015).

The motivational facet of CQ focusses on a person's self-efficacy and personal motives. Perceived self-efficacy is a positive judgement of one's capability (Bandura, 1986). Persons who believe in their capabilities to understand people from other cultures are more likely to engage in international activities. In addition, high efficacy means "When the going gets tough, the tough get going". Individuals who encounter barriers will reengage with greater vigor rather than quit. Hence, individuals with high CQ would highly judge their personal capability and have a greater vigor to engage in IEI activities.

The behavioral facet of CQ suggests that international activities need actual implementation. A high CQ is not only composed of knowledge, but requires action in specific situations. People with high CQ are better able to behave appropriately in different cross-cultural situations. For example, this could mean the selection of an appropriate strategy. In addition, individuals with high CQ are talented mimics (Earley et al., 2007). Mimicry means to imitate key practices from others and serves as a vital capability for entrepreneurs in foreign markets (Nyaupane, Teye, \& Paris, 2008). With such a capability, individuals could discover market opportunities easier than others in other cultural contexts. Therefore, entrepreneurs with a high level of CQ would have a stronger intention to conduct international entrepreneurship. 
From the process perspective of CQ, a person with high level of CQ has a greater capacity to store and categorize new experiences. This may decrease the uncertainty of conducting international entrepreneurial activities, and thus increases the intention to engage. For example, international experience has a significant positive influence on IEI (Sommer, 2013).

From our discussion of the four facets of $\mathrm{CQ}$, we hypothesize that individuals with a higher level of CQ would have greater knowledge, more motivation, better executive efficiency and more experience with regard to international entrepreneurial activities. Formally:

Hypothesis 4: The higher the degree of cultural intelligence, the higher the international entrepreneurial intention.

CQ moderates the TPB-IEI relationship as well. CQ enables individuals with a better understanding of foreign cultures. As a consequence, uncertainty with regard to the international environment will be lower, and the international environment will be regarded as more friendly. For example, Nyaupane et al. (2008) found that students' abroad experience changed their original attitude towards local people. For instance, students' positive attitudes toward Dutch people increased at the end of an exchange. Hence, the familiarity with the new culture would strengthen the link between an individuals' attitude and IEI. Therefore, we assume that:

Hypothesis 4a: Cultural intelligence moderates the impact of personal attitude on IEI: the higher CQ, the stronger the PA-IEI relationship.

Similarly, based on the cognitive facet of CQ we argue that individuals with high CQ have more knowledge of foreign cultures. With more knowledge, they are more confident in their judgement, and therefore develop a distance to others' opinions (Triandis, 2006). Hence, high CQ enables individuals to free themselves from their surrounding peoples' opinions. Formally:

Hypothesis 4b: Cultural intelligence moderates the impact of subjective norms on IEI: The higher CQ, the weaker the SN-IEI relationship.

In addition, the behavioral aspect of CQ suggests that adaption is not only thinking about what to do, but also taking actions in specific situations. This indicates that an entrepreneur with a high level of CQ is able to determine when and how to perform activities related to international entrepreneurship. Such a behavioral control ability reduces the risk and thus increases the willingness to 
conduct IE. Therefore, a higher degree of CQ could enhance the effect of PBC on IEI. We assume that:

Hypothesis 4c: Cultural intelligence moderates the impact of perceived behavioral control on IEI: The higher CQ, the stronger the PBC-IEI relationship.

\subsubsection{Global mindset and IEI}

GM is defined as a mindset "that combines an openness to and awareness of diversity across cultures and markets with a propensity and ability to synthesize across this diversity" (Gupta \& Govindarajan, 2002, p. 117). A global mindset captures a frame of reference based on interacting diversity (Earley et al., 2007). A global mindset involves scanning the world from a broad perspective, looking for unexpected trends and opportunities to achieve personal, professional or organizational objectives and searching for the broad picture and context surrounding situations (Rhinesmith, 1992). It also entails embracing the complexity and contradictions inherent in global interactions. This implies that entrepreneurs both accept and embrace the complexity involved in adapting to foreign markets in a global economy. GM involves four facets: personal attributes, cognitive knowledge and skills, motivation, and resources for adapting behavior (Andresen \& Bergdolt, 2017).

The personal attributes of GM refer to a state of mind that is characterized by an orientation towards the outside and openness and willingness to learn from alternative systems of meaning held by others (Levy, Taylor, Boyacigiller, \& Beechler, 2007). Having a global mindset requires six personal characteristics: knowledge, conceptualization, flexibility, sensitivity, judgement and reflection (Srinivas, 1995). With these personal attributes, people tend to be open to themselves and others by rethinking boundaries and changing their behavior. Therefore, individuals with a strong GM would be more open to and eager to learn more about international entrepreneurial activities, which may lead to a stronger intention to engage in them.

The cognitive perspective of GM refers to a combination of openness and awareness of diversity across cultures and markets, and a propensity and ability to synthesize across this diversity (Gupta \& Govindarajan, 2002). GM is the filter through which people look at the world (Gupta \& Govindarajan, 2002). Knowledge, understanding the world, and skills that enable to effectively work in a global context are necessary to sustain and develop a global mindset (Kedia 
\& Mukherji, 1999). A better understanding of the world will lead to lower uncertainty. A higher degree of skills enables entrepreneurs to execute strategies effectively in the global context. Such knowledge and skills enable people to respond to and to create market opportunities. Both elements enable entrepreneurs to conduct international entrepreneurship. An entrepreneur with a grasp of the needs of different markets can build bridges between the needs of different markets and the venture's global experience and capabilities.

The motivational facet of GM addresses the willingness to engage in global activities. The motivational facet of GM indicates that individuals with a strong GM are more willing to learn from others and adjust themselves to dynamic global environments. With a strong GM, entrepreneurs are more motivated to seek rather than reject globally oriented behavior, such as international entrepreneurship activities.

The behavioral facet of GM makes entrepreneurs not only to think globally but also act locally. Kefalas (1998) argues that a global mindset allows individuals to see the world as a whole and to use this perspective to design valuemaximization strategies for everyone involved. Thus, a strong GM makes it possible for entrepreneurs to strengthen value-maximizing strategies and compete in a global market. Equipped with these competitive abilities, entrepreneurs may be more likely to engage in international entrepreneurial activities.

In summary, we expect that people with a strong GM would have personal attributes that are more positive towards international activities, more cognitive knowledge and skills, more motivation, and better behavioral capabilities, which leads to international entrepreneurial intention. Formally:

Hypothesis 5: The higher the degree of global mindset, the higher the international entrepreneurial intention.

We propose no interactions between GM and TPB-antecedents because the GM constructs taps less into behavioral components than CQ. For example, Andresen and Bergdolt (2017) find that only $40 \%$ of the items of the GM construct indicate a behavioral component, whereas $86 \%$ of the items of CQ have a behavioral perspective. Thus, we argue that GM may matter, but matter less, for interactions that involve behavioral intentions. As a consequence, we do not hypothesize moderation effects of GM and TPB for GM's lower degree of behavioral components. 


\subsubsection{CQ, GM, and IEI}

Only few studies focus on the relationship between CQ and GM. Drawing on Earley and Mosakowski (2004), Levy et al. (2007) argue that it is difficult to develop the requisite set of interpersonal skills (CQ) without a fairly high level of global mindset (GM). Thus, they argued that GM is the prerequisite of those skills and abilities that make up CQ. In another vein, Lovvorn and Chen (2011) found that CQ acts as a moderator in the relationship between international experience and global mindset: individuals need cultural intelligence to transform their experiences into a global mindset. Ramsey, Abi Aad, Jiang, Barakat, and Drummond (2016) identified the application scope of CQ and GM. They imply that the concept of CQ ought to be used when the context is focused on interpersonal outcomes, while GM ought to be used when it focusses more on strategic outcomes.

Based on the arguments above, we suppose an interaction between CQ and GM. $\mathrm{CQ}$ reflects the ability for effective interpersonal behavior in the global context. GM reflects the ability to recognize and synthesize information from foreign cultures. Persons who are able to reflect and synthesize this information (GM) and use this perspective in their personal interactions (CQ) would be more effective than those that would lack one of these elements. We propose that a combination of GM and CQ would make an entrepreneur be more aware and able to be inclined towards international entrepreneurship. Figure 5.1 shows the conceptual model of this study. Formally:

Hypothesis 6: Global mindset moderates the impact of cultural intelligence on IEI: The higher GM, the stronger the CQ-IEI relationship. 


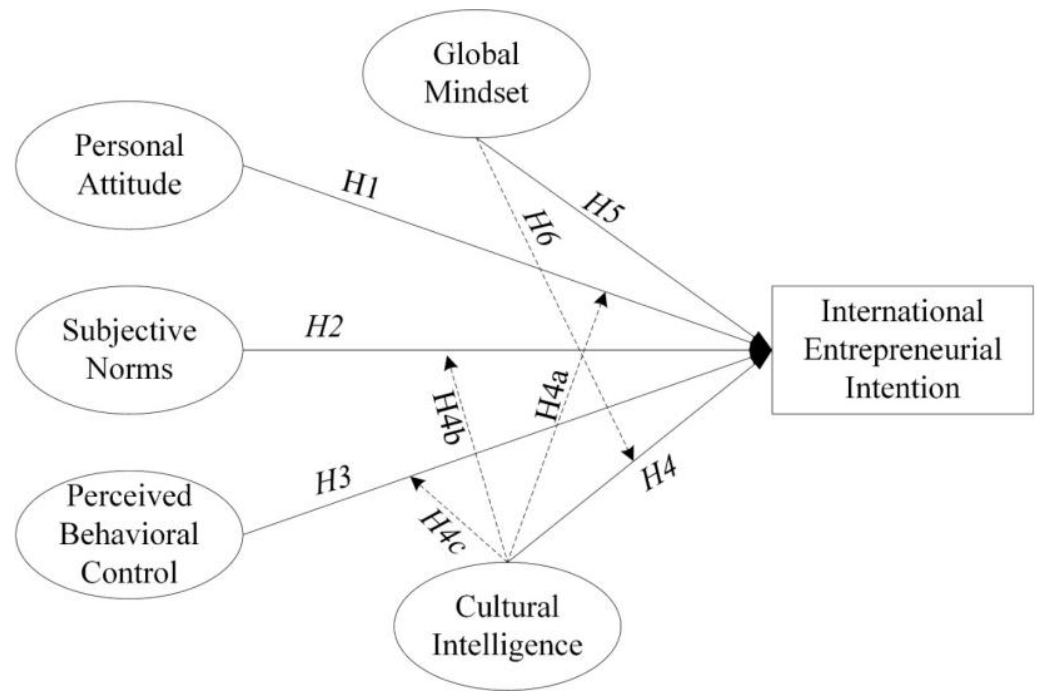

Figure 5.1. The conceptual model of this study.

\subsection{Methods}

\subsubsection{Sample and data collection}

This study is based on undergraduate university business students enrolled in an entrepreneurship course $(N=120)$ at a Dutch university. We study the drivers of IEI among business students for three reasons (Van Gelderen et al., 2008). First, the majority of business students (except accounting students) are not educated with an institutionalized professional identity in mind, which gives space and options for students' career development. Second, business students are exposed to business and management knowledge, and students equipped with this knowledge could be pulled rather than pushed into entrepreneurship. Third, entrepreneurship education has been an important part of business administration education. In addition, studying at an international university, business students get access to a unique international and cross-cultural environment, which provides a fertile ground for nurturing international entrepreneurs.

Data was collected through a self-report survey. A randomly selected group received a questionnaire that focusses on IEI (Questionnaire $A$ available in Appendix A), while the other participants received the questionnaire on EI. During one class session, most students finished the printed survey. We also 
provided an online survey for those who did not attend this particular class or were unwilling or unable to finalize the survey in class. After dropping cases with missing data, our sample consists of 84 respondents (41 from the International group, 43 from the National group), with a response rate of $70 \%$.

Chi-square tests show that there are no significant differences between these two groups on students' age (Pearson Chi-square $=9.122, p=.521$ ), gender (Pearson Chi-square $=0.001, p=.979)$, abroad experience (Pearson Chi-square $=18.421$, $p=.142$ ), language skills (Pearson Chi-square $=3.430, p=.489$ ), nationality (Pearson Chi-square $=8.854, p=.546)$, entrepreneurial experience (Pearson Chisquare $=.009, p=.923$ ), and parents' entrepreneurial experience (Pearson Chisquare $=.607, p=.436$ ). $52.4 \%$ of the students are Dutch, and $35.7 \%$ are German. Most of them (about 70\%) are between 19 to 21 years old and 56\% are male. About $70 \%$ of the students have international study or work experience. More details are shown on the appendix.

\subsubsection{Operationalization}

All items were measured using 7-point rating scales. In the final analysis, the value for each scale is represented by the unweighted mean of its items. The items for the dependent variables, $I E I$ and $E I$, were taken from Kautonen et al. (2015). They reflect the intention to engage in activities aimed at starting an international new venture (or a domestic new venture). To differentiate between IEI and EI, the key word "international" was added to all items in the case of the international group (similarly hereinafter).

Personal Attitude (PA) was measured with students' perceptions on taking steps to start an international new startup in the future by rating six adjective pairs. Subjective Norms $(S N)$ was measured with two sets of scales: one capturing the opinion from students' surrounding important people (family members, best friends and other general important people) on the topic of the students' potential engagement in starting an international new venture. The other measured the degree to which students consider the opinions of others (Kautonen et al., 2015). These scores were multiplied to derive at the SN score. Perceived Behavioral Control (PBC) was measured with four items, with two addressing the ease of performing international entrepreneurial activities and other two captured students' felt control over such behavior. Items for all above constructs are taken from Kautonen et al. (2015). 
Cultural Intelligence $(C Q)$ was measured by nine items of the mini-CQS developed by Ang and Van Dyne (2015). While the original CQ scale contains 20 items (Ang et al., 2007; Charoensukmongkol, 2016), we opted for the miniCQS to shorten the survey with an eye on the response rate.

Global Mindset (GM) was measured with six items which addressed students' attitudes toward and feelings about acting in diverse cultural contexts. Items were adopted from Gupta and Govindarajan (2002). This scale assesses individuals' rather than organizational GM. We transferred the statements from Gupta and Govindarajan (2002) into rating scales. We add students' gender as the control variable. Prior literature has identified gender as an important factor for entrepreneurial intention (Wilson, Kickul, \& Marlino, 2007).

The scales are reliable (Cronbach's $\alpha>0.7$ ). When we divide the sample into the international and national group, the reliabilities differ slightly. In the international group, scales for PA, SN, PBC, IEI and CQ passed the reliability threshold, but GM did not. This is acceptable, however, taken into account the small sample size. In the national group, all scales are reliable except SN. As the deletion of the lowest scoring item did not improve Cronbach's $\alpha$ for SN, we kept all items. Sampling adequacy is acceptable (Kaiser, 1974) for the national group survey $(K M O=.597>.5, p=.000$, see Table 5.2). For the international group we have slightly lower values $(\mathrm{KMO}=.485<.5, \mathrm{p}=.000)$. This is also acceptable, however, taken into account the small sample size.

Table 5.1 Reliability statistics of the scales.

\begin{tabular}{lllllll}
\hline & \multicolumn{5}{l}{ International } & \multicolumn{5}{l}{ National } \\
\cline { 2 - 7 } & Cronbach's & Cronbach's & Dropped & Cronbach's & Cronbach's & Dropped item \\
& $\alpha$ & $\alpha$ & item & $\alpha$ & $\alpha$ & \\
\hline Total & 0.895 & - & - & 0.869 & - & - \\
IEI/EI & 0.971 & - & - & 0.957 & - & - \\
PA & 0.896 & - & - & 0.916 & - & - \\
SN & 0.804 & - & - & 0.649 & 0.665 & - (no \\
& & & - & & & improvement) \\
PBC & 0.716 & - & - & 0.788 & - & - \\
CQ & 0.776 & - & - & 0.734 & - & - \\
GM & 0.559 & 0.648 & Item 1 & 0.715 & - & - \\
\hline
\end{tabular}


Table 5.2 Sampling adequacy.

\begin{tabular}{llll}
\hline KMO and Bartlett's Test & & International & National \\
\hline Kaiser-Meyer-Olkin Measure of sampling adequacy & .485 & .597 \\
Bartlett's Test of Sphericity & Approx. Chi-Square & 1183.980 & 1107.208 \\
& Df & 528 & 561 \\
& Sig. & .000 & .000 \\
\hline
\end{tabular}

\subsubsection{Method of analysis}

Due to the low sample size, we were restricted in the use of methods of analysis and used OLS regression to test the relationship between personal attitude, subjective norms, perceived behavioral control, cultural intelligence and global mindset on (International) Entrepreneurial Intention. To test the moderation effects, we use moderated multiple regression (Cohen, West, \& Aiken, 2014). We report the standardized coefficients.

\section{$5.4 \quad$ Results}

Table 5.3 displays the correlation table. For the first part of the analyses, two OLS regressions were calculated. Results in Table 5.4 suggest that personal attitude has a positive, significant relationship with both international entrepreneurial intention $(b=.611, p=.000)$ and national entrepreneurial intention ( $b=.892, p=.000)$. The result provide support for hypothesis 1 .

Table 5.3 Correlation table.

\begin{tabular}{llllllll}
\hline & 1 & 2 & 3 & 4 & 5 & 6 & 7 \\
\hline IEI & 1 & & & & & & \\
Gender & -.046 & 1 & & & & & \\
PA & $.726^{* *}$ & .105 & 1 & & & & \\
SN & $.546^{* *}$ & .180 & $.563^{* *}$ & 1 & & & \\
PBC & $.499^{* *}$ & .130 & $.456^{* *}$ & $.437^{* *}$ & 1 & & \\
GM & .167 & .272 & $.379^{*}$ & .228 & .267 & 1 & \\
CQ & .065 & .061 & .088 & .029 & .291 & $.660^{* *}$ & 1 \\
\hline EI & 1 & & & & & & \\
Gender & -.264 & 1 & & & & & \\
PA & $.907^{* *}$ & -.246 & 1 & & & & \\
SN & $.356^{*}$ & -.038 & .270 & 1 & & & \\
\hline
\end{tabular}




\begin{tabular}{llllllll}
\hline PBC & $.302^{*}$ & -.007 & $.320^{*}$ & $.362^{*}$ & 1 & & \\
GM & .082 & .154 & .145 & .186 & .290 & 1 & \\
CQ & .015 & -.150 & -.038 & .209 & .206 & $.477^{* *}$ & 1 \\
\hline
\end{tabular}

Note: ${ }^{* * *} \mathrm{p}<.01,{ }^{* *} \mathrm{p}<.05, * \mathrm{p}<.1$, two-tailed.

In addition, the results indicate no significant findings on other direct relationships for either the international nor national entrepreneurial intention.

Table 5.4 Direct effects on (international) entrepreneurial intention.

\begin{tabular}{lll}
\hline Variables & International & National \\
\hline Constant) & & \\
Gender (female=1) & $-.125(.279)$ & $-.014(.848)$ \\
Personal Attitude & $.611(.000)^{* * *}$ & $.892(.000)^{* * *}$ \\
Subjective Norms & $.181(.188)$ & $.123(.099)^{*}$ \\
Perceived behavioral control & $.182(.173)$ & $-.014(.848)$ \\
Cultural Intelligence & $.069(.658)$ & $.072(.381)$ \\
Global Mindset & $-.166(.324)$ & $-.098(.234)$ \\
& $R^{2}=.616 * * *$ & $R^{2}=.845^{* * *}$ \\
& $d f=40$ & $d f=42$ \\
& $F=9.087$ & $F=32.767$ \\
\hline
\end{tabular}

Note: ${ }^{* * *} \mathrm{p}<.01,{ }^{* *} \mathrm{p}<.05, * \mathrm{p}<.1$

To test the moderation hypotheses, a series of moderated regression analyses was run. In models 1a-e, moderations of CQ on the relationship between TBP antecedents (PA, SN, and PBC) and IEI were analyzed. The result in Table 5.5 indicate a negative, significant interaction between $C Q$ and PA in the model with IEI (model 1c, $b=-.296, p<.05$ ). Explained variance increases by $7.4 \%$. Results also suggest a negative interaction between CQ and SN in the model with IEI (model 1d, $b=-.244, p<.05$ ), which increases the explained variance by $5 \%$. These findings run counter to hypothesis $4 \mathrm{a}$, while they support hypothesis $4 \mathrm{~b}$. The result shows no significant moderating effects of CQ on PBC, which fails to support hypothesis $4 \mathrm{c}$.

In models 2a-e, moderations of CQ on the relationships between PA, SN, and PBC and EI were tested. The results in Table 5 indicate no interaction between CQ and PA, SN, and PBC in the model with EI as a dependent variable. Models 1f and $2 \mathrm{f}$ show the moderation of GM on CQ for IEI and EI. Results show no significant interactions between GM and CQ for neither IEI nor EI. 
Table 5.5 Moderated regression analyses.

\begin{tabular}{|c|c|c|c|c|c|c|c|c|c|c|c|c|}
\hline \multirow{2}{*}{ Variables } & \multicolumn{6}{|c|}{ International Entrepreneurial Intention } & \multicolumn{6}{|c|}{ Entrepreneurial Intention } \\
\hline & $1 \mathrm{a}$ & $1 \mathrm{~b}$ & $1 \mathrm{c}$ & $1 \mathrm{~d}$ & $1 \mathrm{e}$ & 1f & $2 \mathrm{a}$ & $2 b$ & $2 \mathrm{c}$ & $2 \mathrm{~d}$ & $2 \mathrm{e}$ & $2 \mathrm{f}$ \\
\hline \multicolumn{13}{|l|}{ (Constant) } \\
\hline Gender & -.161 & -.159 & $-.196 *$ & -.157 & -.172 & -.122 & -.046 & -.041 & -.038 & -.039 & -.035 & -.041 \\
\hline \multicolumn{13}{|l|}{ Attitude } \\
\hline $\begin{array}{l}\text { Subjective } \\
\text { Norms }\end{array}$ & .180 & .175 & $.280 * *$ & $.224 *$ & .191 & .203 & $.128 *$ & $.124 *$ & $.126^{*}$ & $.140^{*}$ & $.138 *$ & $.132 *$ \\
\hline $\begin{array}{l}\text { Perceived } \\
\text { Behavioral } \\
\text { Control }\end{array}$ & .188 & .201 & .086 & .103 & .140 & .162 & -.023 & -.027 & -.025 & -.026 & -.018 & -.009 \\
\hline $\begin{array}{l}\text { Cultural } \\
\text { Intelligence }\end{array}$ & \multicolumn{11}{|c|}{ Intelligence } & \\
\hline CQ*PA & & & $-.296 * *$ & & & & & & .032 & & & \\
\hline $\mathrm{CQ} * \mathrm{SN}$ & & & & $-.244 * *$ & & & & & & -.035 & & \\
\hline CQ*PBC & & & & & -.176 & & & & & & -.110 & \\
\hline $\begin{array}{l}\text { Global } \\
\text { Mindset }\end{array}$ & & & & & & -.144 & & & & & & -.059 \\
\hline $\mathrm{GM}^{*} \mathrm{CQ}$ & & & & & & -.102 & & & & & & .051 \\
\hline & $R^{2}=.603$ & $R^{2}=.605$ & $R^{2}=.678$ & $R^{2}=.655$ & $R^{2}=.630$ & $R^{2}=.622$ & $R^{2}=.838$ & $R^{2}=.839$ & $R^{2}=.840$ & $R^{2}=.840$ & $R^{2}=.850$ & $R^{2}=.844$ \\
\hline & $* * *$ & $* * *$ & $* * *$ & $* * *$ & $* * *$ & $* * *$ & $* * *$ & $* * *$ & $* * *$ & $* * *$ & $* * *$ & $* * *$ \\
\hline & & $\Delta R^{2}=.001$ & $\Delta R^{2}=.074$ & $\Delta R^{2}=.050$ & $\Delta R^{2}=.025$ & $\Delta R^{2}=.008$ & & $\Delta R^{2}=.000$ & $\Delta R^{2}=.001$ & $\Delta R^{2}=.001$ & $\Delta R^{2}=.011$ & $\Delta R^{2}=.002$ \\
\hline & $d f=40$ & $d f=40$ & $d f=40$ & $d f=40$ & $d f=40$ & $d f=40$ & $d f=42$ & $d f=42$ & $d f=42$ & $d f=42$ & $d f=42$ & $d f=42$ \\
\hline & $F=13.684$ & $F=10.703$ & $F=11.942$ & $F=10.747$ & $F=9.645$ & $F=9.315$ & $F=49.321$ & $F=38.546$ & $F=31.465$ & $F=31.476$ & $F=34.044$ & $F=32.532$ \\
\hline
\end{tabular}

Note: $* * * p<.01, * * p<.05, * p<.1$. n.s. not significant. 
To illustrate the significant interactions regarding hypotheses $4 \mathrm{a}$ and $4 \mathrm{~b}$, we plot the moderation effects of CQ from Model 1c and 1d. As shown in Figure 5.2, those that score high on CQ have a weaker relationship between PA and IEI (less steep slope). This runs counter to hypothesis 4 a. Figure 5.3 shows the interaction effect of CQ on the relationship between SN and IEI. Those that score high on CQ have a weaker relationship between SN and IEI, which lends support to hypothesis $4 \mathrm{~b}$.

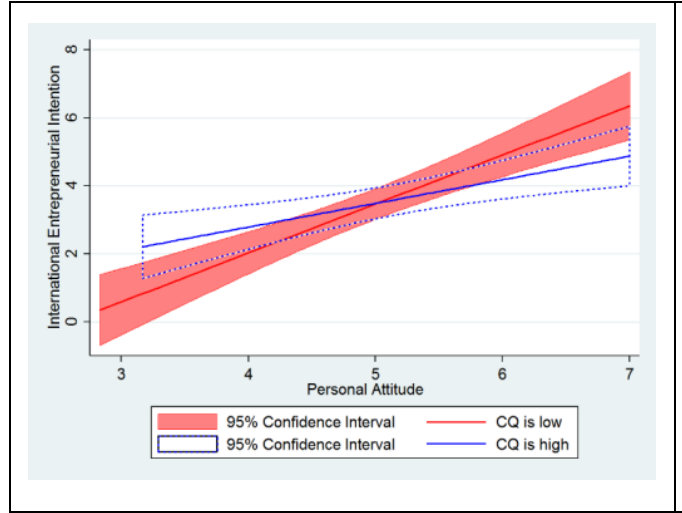

Figure 5.2. The interaction effect of $\mathrm{CQ}$ and PA on IEI.

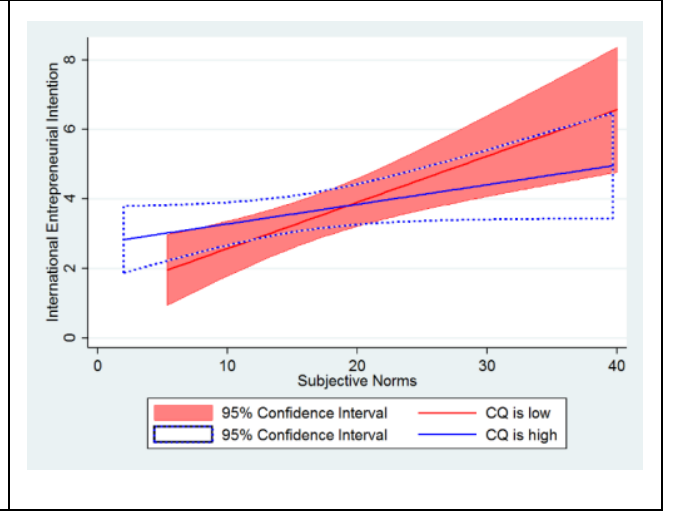

The interaction effect of CQ and SN on IEI.

\subsection{Discussion}

The goal of this study was to identify the drivers of students' IEI, by analyzing the effects of two cross-cultural competences - cultural intelligence and global mindset - in the context of the TPB framework. Our analyses reveal surprising findings (Table 5.6).

Table 5.6 Summary results of hypothesis tests.

\begin{tabular}{llll}
\hline Hypothesis & & Expected & Result \\
\hline$H 1:$ & PA -> IEI & pos. & pos. \\
$H 2:$ & SN -> IEI & pos. & $n . s$. \\
$H 3:$ & PBC -> IEI & pos. & $n . s$. \\
$H 4:$ & CQ -> IEI & pos. & $n . s$. \\
$H 4 a:$ & CQ * PA -> IEI & pos. & neg. \\
$H 4 b:$ & CQ * SN -> IEI & neg. & neg. \\
$H 4 c:$ & CQ $*$ PBC -> IEI & pos. & $n . s$. \\
$H 5:$ & GM -> IEI & pos. & $n . s$. \\
$H 6:$ & GM $*$ CQ -> IEI & pos. & $n . s$. \\
\hline
\end{tabular}

Note: pos. positive; neg. negative; $n$.s. not significant. 
Literature shows that personal attitude, subjective norms and perceived behavioral control have a significant positive relationship with entrepreneurial intention (Kautonen et al., 2015). However, our empirical results show only a positive relationship of PA on IEI. This indicates that the attitude towards IEI may be an important antecedent to intention. Subjective norms show no significant relationship with IEI. Even though the SN constructs is an importance-weighted indicator of others' norms, there is a gap between the perceived social norms and intention. A potential reason may be that, among many other factors (Harren, 1979), in particular parents influence on entrepreneurial career decisions may be limited (Bonnett \& Furnham, 1991). Neither does PBC have a significant influence on IEI. While contrary to the mainstream, our finding is consistent with Van Gelderen et al. (2008), who show that components of PBC (perseverance and self-efficacy) lack support in explaining EI. We suggest that PBC alone may not motivate intentions that lead to action. It facilitates action for those who are motivated to engage in it. It can also imply that students realize that - while they may experience as much control as possible - entrepreneurial activities need a lot of external resources, such as financial support and business networks. As students may have a lower level of these resources, their own degree of PBC may matter less for their IEI.

Direct effects analyses show that neither global mindset nor cultural intelligence have a significant influence on IEI. These results are surprising, as we have provided strong arguments for such potential links. We suggest that GM may not be directly related to IEI because GM rather refers to a mindset than to intentions that lead to actions. With regard to the missing link between CQ and IEI, we can speculate that CQ as such is context-free and may be enacted in any other career choice, with an international entrepreneurial intention being only one possible career choice.

Moderation effects analyses show that only the interactions of CQ and PA, as well as CQ and SN towards IEI are significant. From the discussion of the dimensions of CQ follows that a high degree of CQ implies a high degree of knowledge of and high adaptive capability to new cultural contexts. When individuals have enough knowledge of new cultural contexts and can adapt effectively to new cultures, they may not view conducting an international new business as challenging as without a high level of CQ. Also, student with a high level of CQ are more likely to see the difficulties in IE activities, hence are less 
likely to intent to act, even those that may initially value international entrepreneurship.

A similar moderation effect was found regarding the negative impact of CQ on SN-IEI relationship (Figure 5.3). The positive relation between SN and IEI is lower for high-CQ students than for low-CQ students. This suggest that those who have a low degree of CQ are impacted more in terms of IEI by what their environment says. It might because that sufficient knowledge of a new cultural context reduces the extent of importance of other important people's opinion. This result is in line with the independence of judgement that is facilitated by a high level of CQ and supports hypothesis $4 \mathrm{~b}$.

To illustrate the significant interactions regarding hypotheses 3 and 4, we plot the moderation effects of firm size from Model 5 of the Tobit regressions. As shown in Figure 5.1, the larger firms in our sample generally have higher levels of nonfamily management than smaller firms. Consistent with hypothesis 3 , the downward slope of the nonfamily management variable for larger family firms becomes gentler as family ownership increases, meaning that the demand for nonfamily managers does not vary as much According to family ownership for larger family firms as it does for smaller family firms.

In support of hypothesis 4 (Figure 5.2), a similar moderation effect was found regarding the negative impact of succession intention on nonfamily management; the reduction in the use of nonfamily managers among firms with transgenerational succession intentions is lower in larger firms than that in smaller ones.

To illustrate the significant interactions regarding hypotheses 3 and 4, we plot the moderation effects of firm size from Model 5 of the Tobit regressions. As shown in Figure 5.1, the larger firms in our sample generally have higher levels of nonfamily management than smaller firms. Consistent with hypothesis 3 , the downward slope of the nonfamily management variable for larger family firms becomes gentler as family ownership increases, meaning that the demand for nonfamily managers does not vary as much according to family ownership for larger family firms as it does for smaller family firms. In support of hypothesis 4 (Figure 5.2), a similar moderation effect was found regarding the negative impact of succession intention on nonfamily management; the reduction in the use of nonfamily managers among firms with transgenerational succession intentions is lower in larger firms than that in smaller ones. 


\subsection{Conclusions}

\subsubsection{Theoretical implications}

Our study contributes to the literature by drawing upon the concepts of global mindset and cultural intelligence, to develop a framework that explains the antecedents of international entrepreneurial intention based on an addition to the TPB-framework.

The significant moderation effects of CQ on the relationships between PA and IEI and SN and IEI show that it is useful to combine the literatures of crosscultural competence and international entrepreneurship to move closer to a complete model. Future studies could follow this direction and explore the relationship between cross-cultural competence and other constructs from the international entrepreneurship domain, for example the international performance of international new ventures. In addition, exploring the mechanisms behind the relations would contribute to a deeper understanding of IE(I). We suggest to integrate other constructs such as firm-level capabilities as a theoretical foundation for an application to our findings to international new ventures rather than student entrepreneurs. Further, our results show no significant direct linear relationships between GM, CQ to IEI. In addition, there may be non-linear relationships between these constructs. Future studies may identify those non-linear relationships. Studies following this direction take a step further to explain the role of cross-cultural competences in the field of international entrepreneurship and international entrepreneurship education.

\subsubsection{Practical implications}

Prior studies confirmed the role of entrepreneurship education in enhancing students' EI (Marques, Ferreira, Gomes, \& Gouveia Rodrigues, 2012; Sánchez, 2013; Turker \& Sonmez Selçuk, 2009; Zhang, Duysters, \& Cloodt, 2014). For educators, policy makers and university management, results of our study provide some important implications. First, if a limited link between TPB and IEI would be a result of a lack of in-depth education on IEI, educators could emphasize the international element more. Second, if a missing link between PBC and IEI would be a result of a lack of practical engagement with international entrepreneurship, entrepreneurship education could emphasize the 
international domain more. For example, by integrating international entrepreneurship in an applied Lean-Startup class (Harms, 2015) or by paying particular attention to the specifics of STEM students (Maresch, Harms, Kailer, \& Wimmer-Wurm, 2016). Third, since a high CQ could make students more independent from their environment's opinion, educators may think about how to introduce CQ into the curriculum.

\subsubsection{Limitations and future research}

This study has taken a step in the direction of analysing the relationship between GM, CQ, PA, SN, PBC and IEI/EI on a student sample. However, it is possible that analyses of target groups with different working or entrepreneurial experience may result in different findings. Also, the small sample size limits the choice of methods of analysis as well as the power of our results. Future studies could extend the sample size to fulfil the criteria for using Structural Equation Modelling, to reap its' advantages compared to OLS (Henseler, Hubona, \& Ray, 2016). In addition, other constructs could be added to our model in future studies. For instance, need for achievement, internal locus of control, self-efficacy (Kristiansen \& Indarti, 2004), and social media network (Seroka-Stolka \& Tomski) are relevant constructs that could explain IEI. 


\section{References}

Ajzen, I. (1985). From intentions to actions: A theory of planned behavior. In Action control (pp. 11-39): Springer.

Ajzen, I. (1991). The theory of planned behavior. Organizational Behavior and Human Decision Processes, 50(2), 179-211. doi:10.1016/0749-5978(91)90020-t

Ajzen, I. (2002). Perceived behavioral control, self - efficacy, locus of control, and the theory of planned behavior 1. Journal of applied social psychology, 32(4), 665683. doi:10.1111/j.1559-1816.2002.tb00236.x

Andresen, M., \& Bergdolt, F. (2017). A systematic literature review on the definitions of global mindset and cultural intelligence-Merging two different research streams. The International Journal of Human Resource Management, 28(1), 170-195. doi:10.1080/09585192.2016.1243568

Ang, S., \& Van Dyne, L. (2015). Handbook of cultural intelligence: Routledge.

Ang, S., Van Dyne, L., Koh, C., Ng, K. Y., Templer, K. J., Tay, C., \& Chandrasekar, N. A. (2007). Cultural intelligence: Its measurement and effects on cultural judgment and decision making, cultural adaptation and task performance. Management and Organization Review, 3(3), 335-371. doi:https://doi.org/10.1111/j.1740-8784.2007.00082.x

Bandura, A. (1986). The explanatory and predictive scope of self-efficacy theory. Journal of social and clinical psychology, 4(3), 359-373. doi:10.1521/jscp.1986.4.3.359

Bonnett, C., \& Furnham, A. (1991). Who wants to be an entrepreneur? A study of adolescents interested in a young enterprise scheme. Journal of economic psychology, 12(3), 465-478. doi:https://doi.org/10.1016/0167-4870(91)90027Q

Brislin, R., Worthley, R., \& Macnab, B. (2006). Cultural intelligence: Understanding behaviors that serve people's goals. Group \& Organization Management, 31(1), 40-55. doi:10.1177/1059601105275262

Chandwani, R., Agrawal, N. M., \& Kedia, B. L. (2016). Mindfulness: Nurturing global mind - set and leadership. Thunderbird International Business Review, 58(6), 617-625. doi:10.1002/tie.21760

Charoensukmongkol, P. (2015). Cultural intelligence of entrepreneurs and international network ties: The case of small and medium manufacturing firms in Thailand. Management Research Review, 38(4), 421-436. doi:10.1108/Mrr-09-20130214

Charoensukmongkol, P. (2016). Cultural intelligence and export performance of small and medium enterprises in Thailand: Mediating roles of organizational 
capabilities. International Small Business Journal, 34(1), 105-122. doi:10.1177/0266242614539364

Cohen, P., West, S. G., \& Aiken, L. S. (2014). Applied multiple regression/correlation analysis for the behavioral sciences: Psychology Press.

Crick, D. (2009). The internationalisation of born global and international new venture SMEs. International Marketing Review, 26(4/5), 453-476. doi:10.1108/02651330910971986

Earley, P. C. (2002). Redefining interactions across cultures and organizations: Moving forward with cultural intelligence. Research in organizational behavior, 24, 271-299. doi:10.1016/S0191-3085(02)24008-3

Earley, P. C., Ang, S., \& Tan, J.-S. (2006). CQ: Developing cultural intelligence at work: Stanford University Press.

Earley, P. C., \& Mosakowski, E. (2004). Cultural intelligence. Harvard Business Review, 82(10), 139-146. doi:PMID: 15559582

Earley, P. C., Murnieks, C., \& Mosakowski, E. (2007). Cultural intelligence and the global mindset. In The Global Mindset (pp. 75-103): Emerald Group Publishing Limited.

Gupta, A. K., \& Govindarajan, V. (2002). Cultivating a global mindset. Academy of Management Perspectives, 16(1), 116-126.

Harms, R. (2015). Self-regulated learning, team learning and project performance in entrepreneurship education: Learning in a lean startup environment. Technological Forecasting and Social Change, 100, 21-28. doi:10.1016/j.techfore.2015.02.007

Harren, V. A. (1979). A model of career decision making for college students. Journal of vocational behavior, 14(2), 119-133. doi:https://doi.org/10.1016/0001$\underline{\text { 8791(79)90065-4 }}$

Henseler, J., Hubona, G., \& Ray, P. A. (2016). Using PLS path modeling in new technology research: updated guidelines. Industrial management \& data systems, 116(1), 2-20. doi:10.1108/Imds-09-2015-0382

Janssens, M., \& Brett, J. M. (2006). Cultural intelligence in global teams: A fusion model of collaboration. Group \& Organization Management, 31(1), 124-153. doi:10.1177/1059601105275268

Kaiser, H. F. (1974). An index of factorial simplicity. Psychometrika, 39(1), 31-36. doi:10.1007/BF02291575

Kark, R., \& Van Dijk, D. (2007). Motivation to lead, motivation to follow: The role of the self-regulatory focus in leadership processes. Academy of Management Review, 32(2), 500-528. doi:10.5465/Amr.2007.24351846

Kautonen, T., van Gelderen, M., \& Fink, M. (2015). Robustness of the theory of planned behavior in predicting entrepreneurial intentions and actions. Entrepreneurship Theory and Practice, 39(3), 655-674. doi:10.1111/etap.12056 
Kedia, B. L., \& Mukherji, A. (1999). Global managers: Developing a mindset for global competitiveness. Journal of World Business, 34(3), 230-251. doi:10.1016/S1090-9516(99)00017-6

Kefalas, A. G. (1998). Think globally, act locally. Thunderbird International Business Review, 40(6), 547-562. doi:10.1002/(SICI)15206874(199811/12)40:6<547::AID-TIE3>3.0.CO;2-F

Kolvereid, L. (1996). Organizational employment versus self-employment: Reasons for career choice intentions. Entrepreneurship Theory and Practice, 20(3), 23-31. doi:10.1177/104225879602000302

Kristiansen, S., \& Indarti, N. (2004). Entrepreneurial intention among Indonesian and Norwegian students. Journal of Enterprising Culture, 12(01), 55-78. doi:10.1142/S021849580400004X

Levy, O., Taylor, S., Boyacigiller, N. A., \& Beechler, S. (2007). Global mindset: A review and proposed extensions. In The Global Mindset (pp. 11-47): Emerald Group Publishing Limited.

Lovvorn, A. S., \& Chen, J.-S. (2011). Developing a global mindset: The relationship between an international assignment and cultural intelligence. International Journal of Business and Social Science, 2(9). doi:Corpus ID: 41475020

Manyika, J., Lund, S., Bughin, J., Woetzel, J. R., Stamenov, K., \& Dhingra, D. (2016). Digital globalization: The new era of global flows (Vol. 4): McKinsey Global Institute San Francisco.

Maresch, D., Harms, R., Kailer, N., \& Wimmer-Wurm, B. (2016). The impact of entrepreneurship education on the entrepreneurial intention of students in science and engineering versus business studies university programs. Technological Forecasting and Social Change, 104, 172-179. doi:10.1016/j.techfore.2015.11.006

Marques, C. S., Ferreira, J. J., Gomes, D. N., \& Gouveia Rodrigues, R. (2012). Entrepreneurship education: How psychological, demographic and behavioural factors predict the entrepreneurial intention. Education+ Training, 54(8/9), 657-672. doi:https://doi.org/10.1108/00400911211274819

Maznevski, M. L., \& Lane, H. W. (2004). Shaping the global mindset: Designing educational experiences for effective global thinking and action. In Crossing Cultures (pp. 191-204): Routledge.

Mets, T. (2014). How "born global" SMEs are born: Small emergent country cases. Paper presented at the 27th Annual SEAANZ Conference, Sydney.

Muzychenko, O. (2008). Cross-cultural entrepreneurial competence in identifying international business opportunities. European Management Journal, 26(6), 366-377. doi:https://doi.org/10.1016/j.emj.2008.09.002

Nummela, N., Saarenketo, S., \& Puumalainen, K. (2004). A global mindset-A prerequisite for successful internationalization? Canadian Journal of 
Administrative Sciences/Revue Canadienne des Sciences de l'Administration, 21(1), 51-64. doi:https://doi.org/10.1111/j.1936-4490.2004.tb00322.x

Nyaupane, G. P., Teye, V., \& Paris, C. (2008). Innocents abroad: Attitude change toward hosts. Annals of Tourism Research, 35(3), 650-667. doi:10.1016/j.annals.2008.03.002

Oviatt, B. M., \& McDougall, P. P. (2005). The internationalization of entrepreneurship. Journal of International Business Studies, 36(1), 2-8. doi:10.1057/palgrave.jibs.8400119

Parent-Thirion, A., Vermeylen, G., Van Houten, G., Lyly-YrjÄNÄInen, M., Biletta, I., \& Cabrita, J. (2012). Fifth European working conditions survey Luxembourg: Eurofound. Publications Office of the European Union, 10, 34660.

Pittaway, L., \& Cope, J. (2007). Entrepreneurship education: A systematic review of the evidence. International Small Business Journal, 25(5), 479-510. doi:10.1177/0266242607080656

Ramsey, J. R., Abi Aad, A., Jiang, C., Barakat, L., \& Drummond, V. (2016). Emergence of cultural intelligence and global mindset capital: A multilevel model. Multinational Business Review, 24(2), 106-122. doi:10.1108/MBR-12-20150062

Rhinesmith, S. H. (1992). Global mindsets for global managers. Training \& Development, 46(10), 63-69. doi:GALE|A13528770

Sánchez, J. C. (2013). The impact of an entrepreneurship education program on entrepreneurial competencies and intention. Journal of Small Business Management, 51(3), 447-465. doi:10.1111/jsbm.12025

Seroka-Stolka, O., \& Tomski, P. (2014, 2014). Internet social media and international entrepreneurial intentions. Paper presented at the 2015 WEI International Academic Conference, Vienna.

Sommer, L. (2013). The influence of experience and cognitive style on international entrepreneurial intentions: the contribution of academic education in this relation. Electronic Journal of Research in Educational Psychology, 11(2), 311344.

Souitaris, V., Zerbinati, S., \& Al-Laham, A. (2007). Do entrepreneurship programmes raise entrepreneurial intention of science and engineering students? The effect of learning, inspiration and resources. Journal of Business Venturing, 22(4), 566-591. doi:https://doi.org/10.1016/j.jbusvent.2006.05.002

Srinivas, K. M. (1995). Globalization of business and the third world: Challenge of expanding the mindsets. Journal of Management Development, 14(3), 26-49. doi:10.1108/02621719510078957

Thompson, E. R. (2009). Individual entrepreneurial intent: Construct clarification and development of an internationally reliable metric. Entrepreneurship Theory and Practice, 33(3), 669-694. doi:10.1111/j.1540-6520.2009.00321.x 
Triandis, H. C. (2006). Cultural intelligence in organizations. Group \& Organization Management, 31(1), 20-26. doi:10.1177/1059601105275253

Turker, D., \& Sonmez Selçuk, S. (2009). Which factors affect entrepreneurial intention of university students? Journal of European industrial training, 33(2), 142-159. doi:10.1108/03090590910939049

Van Gelderen, M., Brand, M., van Praag, M., Bodewes, W., Poutsma, E., \& Van Gils, A. (2008). Explaining entrepreneurial intentions by means of the theory of planned behaviour. Career development international, 13(6), 538-559.

Wilson, F., Kickul, J., \& Marlino, D. (2007). Gender, entrepreneurial self-efficacy, and entrepreneurial career intentions: Implications for entrepreneurship education. Entrepreneurship Theory and Practice, 31(3), 387-406. doi:10.1111/j.15406520.2007.00179.x

Yang, J. (2013). The theory of planned behavior and prediction of entrepreneurial intention among Chinese undergraduates. Social Behavior and Personality: An International Journal, 41(3), 367-376. doi:10.2224/sbp.2013.41.3.367

Zhang, Y., Duysters, G., \& Cloodt, M. (2014). The role of entrepreneurship education as a predictor of university students' entrepreneurial intention. International Entrepreneurship and Management Journal, 10(3), 623-641. doi:10.1007/s11365-012-0246-z 


\section{Appendix 5.1}

Questionnaire for the international group.

1. Please read carefully and rate the following statement based on the word pairs provided. (1=strongly disagree; $7=$ strongly agree)

For me, taking steps to start an international new startup in the future would be ...

\begin{tabular}{|l|l|l|l|l|l|l|l|l|}
\hline & & 1 & 2 & 3 & 4 & 5 & 6 & 7 \\
\hline .. unpleasant - attractive. & $\circ$ & $\circ$ & $\circ$ & $\circ$ & $\circ$ & $\circ$ & $\circ$ \\
\hline ... useless - useful. & $\circ$ & $\circ$ & $\circ$ & $\circ$ & $\circ$ & $\circ$ & $\circ$ \\
\hline .. foolish - wise. & $\circ$ & $\circ$ & $\circ$ & $\circ$ & $\circ$ & $\circ$ & $\circ$ \\
\hline . . negative - positive. & $\circ$ & $\circ$ & $\circ$ & $\circ$ & $\circ$ & $\circ$ & $\circ$ \\
\hline ... insignificant - important. & $\circ$ & $\circ$ & $\circ$ & $\circ$ & $\circ$ & $\circ$ & $\circ$ \\
\hline ... tiresome - inspiring. & $\circ$ & $\circ$ & $\circ$ & $\circ$ & $\circ$ & $\circ$ & $\circ$ \\
\hline
\end{tabular}

2. Please read each statement carefully and select the response that best describes your feelings. (1=strongly disagree; $7=$ strongly agree)

\begin{tabular}{|l|l|l|l|l|l|l|l|l|}
\hline & 1 & 2 & 3 & 4 & 5 & 6 & 7 \\
\hline $\begin{array}{l}\text { My closest family members think that I should } \\
\text { take steps to start an international new startup } \\
\text { in the future. }\end{array}$ & $\circ$ & $\circ$ & $\circ$ & $\circ$ & $\circ$ & 0 & $\circ$ \\
\hline $\begin{array}{l}\text { My best friends think that I should take steps } \\
\text { to start an international new startup in the } \\
\text { future. }\end{array}$ & $\circ$ & $\circ$ & $\circ$ & $\circ$ & $\circ$ & $\circ$ & $\circ$ \\
\hline $\begin{array}{l}\text { Other people who are important to me think } \\
\text { that I should take steps to start an international } \\
\text { new startup in the future. }\end{array}$ & $\circ$ & $\circ$ & $\circ$ & $\circ$ & $\circ$ & $\circ$ & $\circ$ \\
\hline
\end{tabular}

And how much would you care about what these people think, if you wanted to take steps to start an international business in the future. (1=totally unimportant; $7=$ very important)

\begin{tabular}{|l|l|l|l|l|l|l|l|l|}
\hline My closest family members. & $\circ$ & $\circ$ & $\circ$ & $\circ$ & $\circ$ & $\circ$ & $\circ$ \\
\hline My best friends. & $\circ$ & $\circ$ & $\circ$ & $\circ$ & $\circ$ & $\circ$ & $\circ$ \\
\hline $\begin{array}{l}\text { Other people who are important to me } \\
\text { generally. }\end{array}$ & $\circ$ & $\circ$ & $\circ$ & $\circ$ & $\circ$ & $\circ$ & $\circ$ \\
\hline
\end{tabular}

3. Please read each statement carefully and select the response that best describes your capabilities. (1=strongly disagree; $7=$ strongly agree)

\begin{tabular}{|l|l|l|l|l|l|l|l|l|}
\hline & 1 & 2 & 3 & 4 & 5 & 6 & 7 \\
\hline $\begin{array}{l}\text { If I wanted to, I could take steps to start an } \\
\text { international new startup in the future. }\end{array}$ & $\circ$ & $\circ$ & $\circ$ & $\circ$ & $\circ$ & $\circ$ & $\circ$ \\
\hline
\end{tabular}




\begin{tabular}{|c|c|c|c|c|c|c|c|}
\hline $\begin{array}{l}\text { If I took steps to start an international new } \\
\text { startup in the future, I would be able to } \\
\text { control the progress of the process to a } \\
\text { great degree myself. }\end{array}$ & $\circ$ & 0 & 0 & 0 & ○ & O & 0 \\
\hline $\begin{array}{l}\text { It would be easy for me to take steps to start } \\
\text { an international new startup in the future. }\end{array}$ & $\circ$ & 0 & 0 & 0 & 0 & 0 & 0 \\
\hline $\begin{array}{l}\text { If I wanted to take steps to start an } \\
\text { international new startup in the future, no } \\
\text { external factor, independent of myself, } \\
\text { would hinder me in taking such action. }\end{array}$ & $\circ$ & 0 & 0 & 0 & ○ & 0 & 0 \\
\hline \multicolumn{8}{|c|}{$\begin{array}{l}\text { 4. Please read each statement carefully and select the response that best describes your } \\
\text { states. ( } 1=\text { strongly disagree; } 7=\text { strongly agree) }\end{array}$} \\
\hline & 1 & 2 & 3 & 4 & 5 & 6 & 7 \\
\hline $\begin{array}{l}\text { I plan to take steps to start an international } \\
\text { new startup in the future. }\end{array}$ & $\circ$ & 0 & o & 0 & 0 & O & ○ \\
\hline $\begin{array}{l}\text { I intend to take steps to start an } \\
\text { international new startup in the future. }\end{array}$ & $\circ$ & 0 & 0 & 0 & ० & ○ & O \\
\hline $\begin{array}{l}\text { I will try to take steps to start an } \\
\text { international new startup in the future. }\end{array}$ & $\circ$ & O & 0 & 0 & 0 & O & 0 \\
\hline \multicolumn{8}{|c|}{$\begin{array}{l}\text { 5. Please read each statement carefully and select the response that best describes your } \\
\text { capabilities. ( } 1=\text { strongly disagree; } 7=\text { strongly agree) }\end{array}$} \\
\hline $\begin{array}{l}\text { In interacting with others, country of origin } \\
\text { has an impact on whether or not I assign } \\
\text { equal status to them. }\end{array}$ & 1 & 2 & 3 & 4 & 5 & 6 & 7 \\
\hline $\begin{array}{l}\text { I consider myself as open to ideas from } \\
\text { other countries and cultures as I am to ideas } \\
\text { from my own country and culture of origin. }\end{array}$ & $\circ$ & 0 & o & 0 & 0 & O & o \\
\hline $\begin{array}{l}\text { I find myself exciting in a new cultural } \\
\text { setting. }\end{array}$ & $\circ$ & 0 & O & 0 & 0 & O & 0 \\
\hline $\begin{array}{l}\text { When I am in another culture, I feel } \\
\text { sensitive to the cultural differences without } \\
\text { becoming a prisoner of these differences. }\end{array}$ & $\circ$ & 0 & 0 & 0 & 0 & O & 0 \\
\hline $\begin{array}{l}\text { When interacting with people from other } \\
\text { cultures, I think understanding them as } \\
\text { individuals is more important than viewing } \\
\text { them as representatives of their national } \\
\text { cultures. }\end{array}$ & O & 0 & O & 0 & 0 & 0 & 0 \\
\hline
\end{tabular}




\begin{tabular}{|c|c|c|c|c|c|c|c|}
\hline $\begin{array}{l}\text { I regard my values to be a hybrid of values } \\
\text { acquired from multiple cultures (as } \\
\text { opposed to just one culture). }\end{array}$ & 0 & 0 & 0 & 0 & 0 & 0 & 0 \\
\hline \multicolumn{8}{|c|}{$\begin{array}{l}\text { 6. Read each statement and select each response that best describe your capabilities. } \\
\text { (1=strongly disagree; } 7=\text { strongly agree) }\end{array}$} \\
\hline $\begin{array}{l}\text { I enjoy interacting with people from } \\
\text { different cultures. }\end{array}$ & 1 & 2 & 3 & 4 & 5 & 6 & 7 \\
\hline $\begin{array}{l}\text { I am sure I can deal with the stresses of } \\
\text { adjusting to a culture that is new to me. }\end{array}$ & 0 & 0 & 0 & 0 & 0 & 0 & 0 \\
\hline $\begin{array}{l}\text { I know the cultural values and religious } \\
\text { beliefs of other cultures. }\end{array}$ & 0 & 0 & 0 & 0 & 0 & 0 & 0 \\
\hline $\begin{array}{l}\text { I know the legal and economic systems of } \\
\text { other cultures. }\end{array}$ & 0 & 0 & 0 & 0 & 0 & 0 & 0 \\
\hline $\begin{array}{l}\text { I know the rules (e.g. vocabulary) of other } \\
\text { languages. }\end{array}$ & 0 & 0 & 0 & 0 & 0 & 0 & 0 \\
\hline $\begin{array}{l}\text { I am conscious of the cultural knowledge } \\
\text { when interacting with other people with } \\
\text { different cultural backgrounds. }\end{array}$ & 0 & 0 & 0 & 0 & 0 & 0 & 0 \\
\hline $\begin{array}{l}\text { I check the accuracy of my cultural } \\
\text { knowledge as I interact with people from } \\
\text { different cultures. }\end{array}$ & 0 & 0 & 0 & 0 & O & 0 & 0 \\
\hline $\begin{array}{l}\text { I change my verbal behavior (e.g. accent) } \\
\text { when a cross-culture interaction requires it. }\end{array}$ & 0 & 0 & 0 & 0 & 0 & 0 & 0 \\
\hline $\begin{array}{l}\text { I change my non-verbal behavior when a } \\
\text { cross-culture interaction requires it. }\end{array}$ & 0 & 0 & 0 & 0 & 0 & 0 & 0 \\
\hline
\end{tabular}




\section{Appendix 5.2}

Descriptive statistics of the sample characteristics.

\begin{tabular}{|c|c|c|c|c|c|c|c|c|c|}
\hline \multirow[b]{2}{*}{ Item } & \multirow[b]{2}{*}{ Category } & \multicolumn{3}{|c|}{ International } & \multicolumn{3}{|c|}{ National } & \multicolumn{2}{|c|}{ Group difference } \\
\hline & & Count & $\begin{array}{l}\text { Percent } \\
(\%)\end{array}$ & $\begin{array}{l}\text { Cum. } \\
\text { percent } \\
(\%)\end{array}$ & Count & $\begin{array}{l}\text { Percent } \\
(\%)\end{array}$ & $\begin{array}{l}\text { Cum. } \\
\text { percent } \\
(\%) \\
\end{array}$ & $\begin{array}{l}\text { Pearson } \\
\text { Chi- } \\
\text { square }\end{array}$ & $\begin{array}{l}\text { Asymptotic } \\
\text { Significance } \\
\text { (2-sided) } \\
\end{array}$ \\
\hline \multirow[t]{4}{*}{ Age } & 19 & 11 & 26.8 & 26.8 & 12 & 24.9 & 24.9 & 9.122 & .521 \\
\hline & 20 & 13 & 31.7 & 58.5 & 10 & 23.2 & 51.2 & & \\
\hline & 21 & 6 & 14.6 & 73.2 & 8 & 18.6 & 69.8 & & \\
\hline & Others & 11 & 26.8 & 100 & 13 & 30.2 & 100 & & \\
\hline \multirow[t]{2}{*}{ Gender } & Male & 23 & 56.1 & 56.1 & 24 & 55.8 & 55.8 & .001 & .979 \\
\hline & Female & 18 & 43.9 & 100 & 19 & 44.2 & 100 & & \\
\hline Years of abroad & 0 & 11 & 26.8 & 26.8 & 14 & 32.6 & 32.6 & 18.421 & .142 \\
\hline \multirow[t]{3}{*}{ experience } & 1.5 & 13 & 31.7 & 58.5 & 4 & 9.3 & 41.9 & & \\
\hline & 2.0 & 6 & 14.6 & 73.2 & 10 & 23.3 & 65.1 & & \\
\hline & Others & 11 & 26.8 & 100 & 13 & 30.2 & 100 & & \\
\hline Number of foreign & 1 & 11 & 26.8 & 26.8 & 7 & 16.3 & 16.3 & 3.430 & .489 \\
\hline \multirow{3}{*}{ languages } & 2 & 17 & 41.5 & 68.3 & 17 & 39.5 & 55.8 & & \\
\hline & 3 & 9 & 22.0 & 90.2 & 14 & 32.6 & 88.4 & & \\
\hline & Others & 4 & 9.8 & 100 & 5 & 11.6 & 100 & & \\
\hline \multirow[t]{3}{*}{ Country of Birth } & Netherlands & 20 & 48.8 & 48.8 & 24 & 55.8 & 55.8 & 8.854 & .546 \\
\hline & Germany & 17 & 41.5 & 90.2 & 13 & 30.2 & 86.0 & & \\
\hline & Others & 4 & 9.7 & 100 & 6 & 13.9 & 100 & & \\
\hline \multirow{4}{*}{$\begin{array}{l}\text { Self-entrepreneurial } \\
\text { experience } \\
\text { Parents' entrepreneurial } \\
\text { experience }\end{array}$} & Yes & 12 & 29.3 & 29.3 & 13 & 30.2 & 30.2 & .009 & .923 \\
\hline & No & 29 & 70.7 & 100 & 30 & 69.8 & 100 & & \\
\hline & Yes & 15 & 36.6 & 36.6 & 12 & 27.9 & 27.9 & .607 & .436 \\
\hline & No & 26 & 63.4 & 100 & 30 & 72.1 & 100 & & \\
\hline
\end{tabular}


Early Internationalizing Firms' Capabilities 


\section{CHAPTER 6 \\ Discussion and Conclusions}




\subsection{Introduction}

This $\mathrm{PhD}$ dissertation originated from the idea to explore the drivers behind the rapid and early internationalization and high international performance in young entrepreneurial firms from emerging economies, such as China (Yamakawa, Khavul, Peng, \& Deeds, 2013). Literature shows that young entrepreneurial firms face numerous challenges in achieving high international performance. These challenges include resource deficiency (Cavusgil \& Knight, 2015), liabilities of newness, smallness, and outsidership (Bruderl \& Schussler, 1990; Freeman, Carroll, \& Hannan, 1983; Johanson \& Vahlne, 2009; Zaheer, 1995), and different types of distance (Ghemawat, 2001). Furthermore, in transition economics, such challenges become more severe due to institutional uncertainties (Puffer, McCarthy, \& Boisot, 2010) and environmental uncertainties (Parnell, Lester, Long, \& Köseoglu, 2012).

Young entrepreneurial firms overcome these challenges by leveraging different types of capabilities and strengths (Al-Aali \& Teece, 2014; Knight \& Cavusgil, 2004; Teece, Pisano, \& Shuen, 1997). Topics relate to the relationship between capabilities and firms' performance attract scholars' increasing interests. As a result, the amount of capability-based studies have increased rapidly in the last two decades (Schilke, Hu, \& Helfat, 2018). However, the proliferation of research on capabilities has caused ambiguity in the way that capabilities are conceptualized. Moreover, the question of how firms deploy their capabilities in international entrepreneurship is also understudied. Therefore, this dissertation focuses on answering these two research questions: a) What capabilities do young entrepreneurial firms need; and b) how do these firms configure capabilities to achieve high international performance?

This dissertation answers these research questions with two conceptual and two empirical studies. The main contribution of the conceptual studies is the capability categorization model. The main contribution of the empirical studies is the capability configurations of early internationalizing firms (EIFs).

This chapter summarizes the main findings of this thesis based on the subquestions presented in Section 6.2. After that, this chapter discusses how do these findings contribute to the capability-based perspective as the primary perspective this dissertation adopts (Section 6.3), and to international entrepreneurship (IE) as the primary research field of this dissertation (Section 0 ). Section 6.5 provides 
an illustration based on TikTok and practical implications for IE. The limitations of this dissertation come in the end at Section 6.6.

\subsection{Summary of the findings}

\subsubsection{Chapter 2: Research questions, findings, and contributions}

Chapter 2 provided a content analysis of the EIFs literature in the context of China. This chapter contributes to the integration and consolidation of the knowledge of Chinese EIFs by answering the following question:

Question 2.1: What research topics have been studied in the literature on EIFs in China?

Question 2.2: What are the future research topics to gain a better understanding of EIFs in China?

With regards to question 2.1, this study found that the literature of Chinese EIFs studied the antecedents, elements, and outcomes of early internationalization. Specifically, a key antecedent is managers' socio-cognitive properties; a key element is resource stock; a key outcome is pattern/degree/extent of internationalization. About $30 \%$ of the literature focuses on outcomes. The research focus of these studies is mainly outcome-driven: the majority of these studies focus on analysing the influences from the elements $(53.3 \%)$ and antecedents (22.2\%) to outcomes. Findings from these studies contribute to the knowledge of how and why young entrepreneurial firms from emerging countries internationalize early and a rapid way. Therefore, this study contributes to informing the state-of-the-art of research on Chinese EIFs, and providing suggestions for future research. Concerning question 2.2, this study discovered several promising avenues for future research that could lead to a more in-depth understanding of the IE phenomenon in China. For example, to focus on the influence of the US-China bilateral tariff war, and to examine the processes of learning in Chinese EIFs. Hence, our study contributes significantly to the literature of Chinese EIFs.

Furthermore, this chapter identified specific contextual factors that relate to Chinese EIFs. For instance, guanxi as an informal source of information and resources (Zhang \& Hartley, 2018; Zhou, Wu, \& Luo, 2007), and returnees' networking capabilities that connect domestic and international markets (Bai, 
Johanson, \& Martín Martín, 2017). These contextual factors contribute to the extension of the boundary of IE research. Therefore, this study adds to the knowledge of IE and contribute to the field of general IE research.

\subsubsection{Chapter 3: Research questions, findings, and contributions}

While Chapter 2 discussed the research topics of Chinese IE studies in general, we now focus on the research on the relationship between firm capabilities and IE performance specifically. Chapter $\mathbf{3}$ systematically reviewed the capabilities that are related to international performance in EIFs. This chapter contributes to the existing knowledge by answering the following questions:

Question 3.1: How can we categorize the capabilities that are related to international performance?

Question 3.2: Which capabilities are studied in research on the international performance of EIFs?

With regards to question 3.1, this study provided a capability categorization model that deduced from capabilities' performance implications (Helfat, 2007). In this categorization model, capabilities are divided by internal/external activities and substantive/dynamic dimension. Substantive capabilities address the external fitness and technical efficiency of the firm's activities. Dynamic capabilities address the evolutionary fitness and technical fitness of the firm's activities. Substantive capabilities constitute blocks of internal operation, internal administration, external operation and external administration, based on the distinction between operational and administrative activities. Dynamic capabilities constitute blocks of resource renewal, resource reconfiguration; observation and evaluation, resource acquisition, based on the distinction between exploration and exploitation activities.

In regards to question 3.2, this study found that 73 specific capabilities have been studied. Within these capabilities, 41 of them deal with dynamic capabilities, 13 of them deal with substantive capabilities, and 19 of them are actually capability antecedents or consequences. Most of the dynamic capabilities were related to international market observation and evaluation. These capabilities address the monitoring of international markets, and the identifying and evaluating of new opportunities. As to the substantive capabilities that were studied, most of them relate to international market operation. These capabilities address the 
operational activities in the international markets that contribute to the improvement of firms' external fitness.

As to the contribution, this study informed about the research status of studies on the link between capabilities and international performance of EIFs. Specifically, we identified and categorized capabilities that research linked to international performance of EIFs. To the best of our knowledge, our study is among the first study that focuses on the interface of capabilities and international performance in EIFs. We focus on the frequency as a proxy for the relevance of a particular capability to the research community.

Future IE studies on relevant topics could, for example, take our study as a starting point for meta-analyses. Additionally, future studies could use our results to seek out research gaps in the capabilities that have been overlooked or rarely studied, such as financing capabilities and domestic market-related capabilities. Based on the capability categorization model, we consolidated research on EIFs and international performance, establish connections in this nascent research stream (Jones, Coviello, \& Tang, 2011), and identify several research gaps (Crossan \& Apaydin, 2010).

\subsubsection{Chapter 4: Research questions, findings, and contributions}

While Chapter 3 laid a foundation of capability classification, we now look at how capability combinations influence the performance of EIFs. Chapter 4 focused on exploring the relationship between the configuration of capabilities and EIFs' international performance. This chapter answered the question:

Question 4: What are the capability bundles of Chinese technologybased EIFs use to achieve high international performance?

With regards to the findings, this chapter found that the combination of dynamic bundle of capabilities (among capabilities of marketing, technological, and networking) lead to the high international performance in EIFs. Our analysis on 88 Chinese technology-based EIFs showed that four combinations of capabilities had been used for high international performance. These high performing EIFs mainly showed two ways in terms of capability configuration. The first configuration is the combination of more than two of the marketing, technological, and networking bundles. The second configuration is the combination of strong networking capabilities; however, with large foreign 
customers. By contrast to high performing firms, firms that did not perform well grouped together in two clusters. The first capability configuration cluster is the absence of all three dynamic bundles. The second capability configuration cluster is the presence of only strong technological bundles, but other bundles are absent.

Concerning the contribution, this study provided evidence to explain EIFs' international performance using dynamic bundle of capabilities. As in most of the high-performance solutions, the substantive component of the capability coexists with the dynamic component. This result means, in most of the situations, the dynamic bundle of capabilities contributes positively to the outcome via the synergy of substantive and dynamic capabilities. This study is one among the first empirical studies that bring the concept of dynamic bundle of capabilities into the research of capability-performance relationship.

\subsubsection{Chapter 5: Research questions, findings, and contributions}

While the previous chapters addressed the positive performance implications from capabilities and capability bundle of EIF, we now take the analysis to the personal level. We discuss what factors may contribute to a higher intention of international entrepreneurs. Chapter 5 studied how to enhance college students' intention to start international entrepreneurship from the capability-based perspective. Specifically, this study explored the relationship between two personal level capabilities and international entrepreneurial intention. This chapter answered the question:

Question 5: How are students' personal capabilities related to their intention of international entrepreneurship?

We found no significant direct effects from cultural intelligence and global mindset on international entrepreneurial intention. Moderation analyses suggest a negative, significant moderating effect of cultural intelligence on the relationship between personal attitude and international entrepreneurial intention, and on subjective norms and international entrepreneurial intention. Therefore, simply enhancing the global mindset and cultural intelligence does not contribute to students' international entrepreneurial intention. More is required from entrepreneurship education, such as improving the perception of international entrepreneurship as a valuable career choice. 
With regards to the theoretical implications, this study contributes to the literature by drawing upon the concepts of global mindset and cultural intelligence, to develop a framework that explains the antecedents of international entrepreneurial intention based on an addition to the Theory of Planned Behavior-framework. This chapter brought two personal level capabilities - cultural intelligence and global mindset, into the TPB model to make it a more complete model in explaining students' entrepreneurial intention. This study is an example of applying the personal level capabilities in international entrepreneurship. Together with previous chapters' discussion of firm-level capabilities' international performance implications, this study contributes to a more comprehensive understanding of the capabilities in international entrepreneurship.

\subsection{Contributions to the capability-based perspective}

\subsubsection{Theoretical implications for the capability-based perspective}

The main finding of this dissertation is that dynamic bundle of capabilities contributes to the international performance in EIFs. Consequently, the contribution of this dissertation to the CBP is two-fold. First, this dissertation provided empirical evidence on the efficacy of dynamic bundles in explaining EIFs' performance. Accordingly, this thesis contributes to a more complete model of dynamic capabilities (Peteraf, Di Stefano, \& Verona, 2013). Second, this dissertation presented several pathways of being successful in international markets for EIFs in terms of capability configurations. Therefore, this research provides insights for CBP with the configurational perspective (Ralf Wilden, Devinney, \& Dowling, 2016).

The first implication of this dissertation for the CBP lies in the capability categorization model. Chapter $\mathbf{3}$ categorizes capabilities. Such classification of capabilities provides a foundation for the configuration of different capabilities (Harms, Kraus, \& Schwarz, 2009). Furthermore, this chapter provides insights into identifying under-studied capabilities. This model not only benefits the clarification and categorization of existing capabilities but also lays the foundation of capability configurations. This chapter inspired some future study directions. For example, to discuss the configuration of capabilities within the same categorization and to study capabilities related to domestic activities. 
The second contribution of this dissertation to the CBP relates to the topic of dynamic bundles. The concept of dynamic bundles is raised by Peteraf et al. (2013), who aim to bridge the theoretical disagreement between Teece et al. (1997) and Eisenhardt and Martin (2000). These two influential papers in the CBP literature share different even contradicting opinions over the boundary conditions, sustainable advantage, and competitive advantage of dynamic capabilities (Peteraf et al., 2013). Teece et al. (1997) advocate that dynamic capabilities could contribute to sustainable competitive advantages. By contrast, Eisenhardt and Martin (2000) argue that dynamic capabilities are only "best practices" that cannot lead to sustainable competitive advantages. Based on the need to integrate the two contradictory views, Peteraf et al. (2013) suggest that dynamic capabilities operate in conjunction with simple rules and routines (substantive capabilities) to form a dynamic bundle contributes to sustainable competitive advantages, therefore, reconcile the inconsistencies. Dynamic bundles of capabilities combine dynamic capabilities that target at extending and updating firms' resource base, as well as the more stable routines to control these complex and changing dynamic activities (Peteraf et al., 2013). With the continuous conjunction of these two parts, dynamic bundles of capabilities enable firms to create sustainable value and competitive advantages.

Our findings complement previous capability-based literature that applies linear analysis. Studies with the linear analytical logic present independent factors' net influence, while our study shows elements' combined influence on the outcome of interest. Our results show that substantive capabilities and their corresponding dynamic parts tend to exist in paired combinations. Prior capability-based research claims the independent influence of different capabilities on firm performance (Krasnikov \& Jayachandran, 2008; R. Pinho, 2011; R. Wilden \& Gudergan, 2014). In Chapter 4, 9 out of 12 bundles in the high-performing group are jointly present or absent in the capability solutions. And, 7 out of 9 bundles in the low-performing group are jointly absent or present in the capability solutions. Our results indicate that these dynamic bundles of capabilities complement other capabilities contributing to firm performance (Karna, Richter, \& Riesenkampff, 2016). Such findings provide new insights into the interactions among different types of capabilities leading to the performance that has been ignored by linear and regression-based logical analyses. We, therefore, advance the literature on the relationship between 
capabilities and international performance by considering the influence of dynamic bundles (Waleczek, von den Driesch, Flatten, \& Brettel, 2019).

\subsubsection{Future research agenda for the capability-based perspective}

This dissertation provides the following research agenda for future studies. First, we suggest future studies to delve deeper into how these high-performing firms deploy their substantive and dynamic capabilities to build dynamic bundles of capabilities (Waleczek et al., 2019). Furthermore, we suggest future studies to explore how these dynamic bundles of capabilities mutually interact to drive performance. Future studies could develop qualitative case studies on these topics to uncover how international entrepreneurial firms deploy and configure their capabilities. Additionally, we would encourage further exploration of the relationship between substantive and dynamic capabilities.

Second, we recommend future studies to explore how will the configuration of capabilities differ between countries and industries, since "management practices vary substantively across countries and across firms" (Bloom \& Van Reenen, 2010, p. 215). Due to differences in the market development level and local regulations, firms' strategic actions vary across countries (Stenzel \& Frenzel, 2008). Accordingly, the combinations of capabilities can also be different. For instance, companies in more advanced economies may find branding capabilities more critical; while for those companies from developing economies, massive producing capabilities could be their top priority.

This argument applies to the industry as well. Previous research indicates that firms operating in different industries and/or countries use and emphasize management practices (e.g., human resource management) differently (Ahmad $\&$ Schroeder, 2003). Additionally, firms in different sectors need to deal with different up- and down-stream industry chains. Accordingly, they need different portfolios of capabilities and call for more research attention. For example, new ventures in high-tech industries may find that technological capabilities are more critical than logistic capabilities. Meanwhile, new ventures in the internet industry may need more robust financial capabilities to attract investments to occupy the market early than after sell capabilities. 


\subsection{Contributions to international entrepreneurship}

\subsubsection{Theoretical implications for international entrepreneurship}

Research in IE discusses "the discovery, enactment, evaluation, and exploitation of opportunities - across national borders - to create future goods and services (Oviatt \& McDougall, 2005, p. 540).” Studies in IE mainly focus on exploring the formation, behaviours, and impacts of EIFs (McDougall, Shane, \& Oviatt, 1994). This dissertation contributes to IE research mainly by focusing on EIFs' capabilities - understood as a learned and stable pattern of international activities (Zollo \& Winter, 2002). Therefore, studies in this dissertation have the following contributions to IE.

Two conceptual studies shed lights on the research status and knowledge gaps of Chinese EIFs studies and the capability-international performance studies in IE. Chapter 2 adds to the knowledge of IE by consolidating and integrating the existing literature on Chinese EIFs. This work provides IE scholars with research topics on antecedents, elements and outcomes about Chinese EIFs. Chapter 2 distinguishes itself by focusing on one specific context, which contributes to deepen understanding and explore theoretical boundaries of IE by focusing on the context of one country (Deng, 2012; Jia, You, \& Du, 2012).

Furthermore, this chapter contributes to the scholarship of IE by shedding light on several understudied research questions. We highlighted that some research topics that define the unique contextualization of Chinese EIFs are missing in the existing literature. For instance, policies relate to internationalization (e.g., Belt \& Road Initiative; Wang, Qiu, \& Choi, 2019), entrepreneurship and innovation (e.g., Mass Entrepreneurship \& Innovation; Yan, Gu, Liang, Zhao, \& Lu, 2018), and technology (e.g., Made in China 2025; Li, 2018). With this future research agenda, this study benefits developing a more integrated research agenda on Chinese EIFs for IE scholars.

Our empirical studies have the following theoretical implications for the literature of IE. First, we extend the existing capability-based literature and venture performance in IE by showing the importance of dynamic bundle of capabilities on EIFs' international performance. Prior IE research on capabilities and venture performance predominately focused on the influence from the singular aspect of the capabilities, either substantive or dynamic aspect (e.g., Martin, Javalgi, \& Cavusgil, 2017; Zhou, Wu, \& Barnes, 2012). However, our 
research argues that it is the combination of substantive capabilities and their corresponding dynamic parts that take effect (Di Stefano, Peteraf, \& Verona, 2014; Peteraf et al., 2013). Our results show that neither the substantive nor the dynamic capabilities of the three functional activities contributes to the positive outcome individually or in combination. The dynamic bundle of specific functions stresses the conjunction of the daily operations (substantive) and their updating and reconfigurations (dynamic) to jointly contribute to venture performance (Waleczek et al., 2019). Our finding qualifies Eisenhardt and Martin (2000) assertion that dynamic capabilities are the necessary but insufficient condition for venture performance.

Second, our studies add to the IE literature by providing multiple paths for ventures to achieve similar high international performance. Our results shed lights on the positive influence of capability configurations on EIFs' international performance. Consistent with previous literature, our results showed a high relevance of the dynamic bundles of international marketing and international networking on EIFs' high international performance. Additionally, our results highlight the importance of complementarity between the firm's dynamic bundle of capabilities (Karna et al., 2016). Therefore, our study challenges this study line by providing the configurations of these functional activities related to international marketing and networking. Thus, our study enhances the current research stream that ventures can achieve similar outcome via the different equivalent combinations of capabilities from the configurational perspective (Sjödin, Parida, \& Kohtamäki, 2016).

\subsubsection{Future research agenda for international entrepreneurship}

As to the future research agenda, we recommend following studies on Chinese EIFs to focus on two contextual conditions. The first one is the Mass Entrepreneurship \& Innovation initiative (Yan et al., 2018). The Chinese government introduced the Mass Entrepreneurship \& Innovation initiative in 2015. This initiative aims to improve the entrepreneurship and innovation environment, and to build an innovation-driven and higher-quality economic development in China (Xinhua, 2018). A series of actions have been taken to promote the implementation of this policy. Such as lowering entry barriers, strengthening public services and encouraging college students, scientists and engineers to start new innovative businesses (GEM, 2016). These actions have 
achieved some positive results, such as improved the new venture registration number hugely (Xinhua, 2018). Therefore, it would be interesting to explore how did the Mass Entrepreneurship \& Innovation initiative contribute to the founding of Chinese EIFs. Further, how does this policy helps to relief EIFs' liabilities and growth challenges? Moreover, it would also be interesting to analyze whether and how do conditions inside the EIFs interact with the Mass Entrepreneurship $\&$ Innovation initiative to contribute to the performance from the configuration perspective.

Another possible promising contextual factor, specifically in China, is the Belt $\&$ Road Initiative (Wang et al., 2019). The Belt \& Road Initiative is announced in 2013. It consists of the inland Silk Road Economic Belt and the ocean-based 21st-Century Maritime Silk Road. A central aim of the Belt \& Road Initiative is to improve hard and soft infrastructure in international trade. It has been documented that Belt \& Road Initiative contributes to the internationalization and economic growth in China (Baniya, Rocha Gaffurri, \& Ruta, 2019; Wang et al., 2019). For example, the achievements from the implementation of the Belt \& Road Initiative significantly improve the exports growth in China (Wang et al., 2019). Additionally, the new and improved Belt \& Road Initiative transport infrastructure has significant positive impacts on trade flows of Belt \& Road Initiative countries (Baniya et al., 2019). Therefore, it is interesting to exam whether the Belt \& Road Initiative bring cross-broad exchange opportunities for Chinese EIFs. Furthermore, which group of EIFs sensed and exploit these opportunities and why not others? Moreover, what capabilities and configuration of capabilities do EIFs to catch these opportunities and improve their performance.

\subsection{Practical implications}

\subsubsection{Case analysis on TikTok's capability configurations}

This section presents a short illustration of TikTok's configuration of dynamic bundle of capabilities (technological, international marketing, and international networking) based on publicly available information. 
Technological capabilities: substantive, dynamic, and dynamic bundle

The artificial intelligence (AI) technologies underpin TikTok constitute its substantive technological capabilities. The AI technology powers TikTok to have a large consumer base (Davis, 2019). TikTok uses AI algorithms to learn about app users' preferences and decide the most interesting feeds to them, rather than recommend post and let users select - as what Facebook' apps are doing (Barrett, 2020). Accordingly, TikTok makes its consumers more engaged and more likely to use the app.

As to the dynamic technological capabilities, TikTok showed its dynamism in aspects of sensing and adapting. First, TikTok senses and adopts new technologies to simplify app functions like video editing and make publishing videos easier (Davis, 2019). Therefore, TikTok reduces the threshold for users and increase the user experience, and eventually expands the user base. Second, TikTok actively adapts the app functions and features to local markets (Wun, 2019). TikTok keeps updating its AI algorithms and learning about local users to provide the best user experience to attract app users.

TikTok builds its dynamic bundle of technological capabilities by integrating the newly identified market trends and local market preferences into its substantive AI technologies. As a result, TikTok provides an "easy-to-use interface combining clickbaity news and entertainment with powerful AI to precisely match users" (Fannin, 2019). Eventually, TikTok earned a huge user base shortly after its launch world widely.

International marketing capabilities: substantive, dynamic, and dynamic bundle TikTok showed strong international marketing capabilities to capture a huge group of users in the global market. Several international marketing campaigns have been conducted to gain people's attention. Among which, leveraging hashtag \#challenges is TikTok's enduring successful marketing tactics (Wun, 2019). By running these hashtag campaigns, TikTok called people to react to challenges and attracted numerous followers in the app rapidly. For instance, by running the "\#haidilao" TikTok had more than 15,000 users' participation and 50 million video views (Graziani, 2019). Further, by running the offline answer tea campaign, one TikTok channel accumulated 345,000 followers and garnered over one million likes (Graziani, 2019). Such strong international marketing capabilities contribute to TikTok's substantive user increase. 
Although succeed with hashtag \#challenges, TikTok acts positively to adjust itself to dynamic international markets and build its dynamic international marketing capabilities. For instance, TikTok collaborates with local influencers and leverages local celebrities to promote the app, and increase the user number and drive traffic. In the content-wise, TikTok localizing their content to the Japanese market by adapting the songs and simplifying the movements to ingratiate local users' taste and culture (Wun, 2019). Further, TikTok was actively sensing the content trends in international markets. For example, it was reported that TikTok set up an office in Los Angeles to actively scout for international content trends (Fannin, 2019). Moreover, TikTok showed its dynamic marketing capabilities by displaying advertisements in the most iconic locations in local markets to extend its marketing resources. For example, during new year's eve in 2018, TikTok took over Piccadilly Street, Oxford Circus and Time Square in New York City (Wun, 2019).

TikTok builds its dynamic bundle of technological capabilities by running the hashtag marketing campaigns (substantive marketing), in the meantime, actively replicating its existing marketing strategies and adapting these campaigns and services to local markets (dynamic marketing). As a result, TikTok has promoted the app, created a large number of followers, and continuously increased the app stickiness, consequently acquired international markets.

International networking capabilities: substantive, dynamic, and dynamic bundle

As to the networking aspect, TikTok showed strong substantive international networking capabilities in collaborating with high-end international brands. These brands include Guess, Michael Khors, Haidilao, Oreo, Pizza Hut, and Adidas Neo (Graziani, 2019). By collaborations with brand partnerships, TikTok gets quick access to a large audience. For example, it is estimated that in the marketing campaign partnering with Michael Khors, about 30,000 TikTok users posting their videos which were streamed for over 5 million times (Graziani, 2019).

TikTok showed its dynamic international networking capabilities in acquiring other apps and platforms. While actively cooperates with its network partners, TikTok also expands the networks by acquisitions of other apps. For instance, in 2017, TikTok's parent company ByteDance paid an estimated $\$ 900$ million to acquire Musical.ly. This deal brought TikTok more than 200 million users 
worldwide and a large following in the U.S. (Fannin, 2019). Additionally, ByteDance acquired the News Republic, a global mobile news aggregation service based in France. With such dynamic international networking capabilities, TikTok expanded its network size and gained the existing users.

TikTok builds its dynamic bundle of international networking capabilities by collaborating with high-end brands, meanwhile, actively seeking new partners and acquisitions of comprising apps or platforms. Through its dynamic bundle of international networking capabilities, TikTok gaining increasing attention in international markets and set itself as a premium short-video platform.

\section{Configuration of dynamic bundles}

The three dynamic bundles conjunct with each other and facilitate the success of TikTok in international markets. First, technological dynamic bundle supports TikTok's favourable user experience and provides foundations for its international marketing campaigns and networking activities. TikTok AI algorithms analyse the app user and quickly build sizeable user datasets (Davis, 2019). Using these datasets, TikTok plans and conducts its marketing activities more accurately, also identifies more reliable business partners.

Second, TikTok's marketing dynamic bundle helps to promote the app and brings more users. More app users mean more data. The increasing amount of data help TikTok to upgrade their AI algorithms' learning ability, and build a stronger technological dynamic bundle in the end. Additionally, more app users mean more traffic and higher exposure. Such big traffic and high exposure provide a great attraction for business partners, therefore, benefit the networking dynamic bundle.

Third, the networking dynamic bundle back feeds technological and marketing dynamic bundle with more app users. The acquisitions bring TikTok a large number of ready-made international users. Meanwhile, collaborations with highend brands promote the app and bring marketing success. Eventually, the configuration of technological, marketing, and networking dynamic bundles helps TikTok to build a sustainable advertising business (Osawa \& Zhang, 2019) and contributes to its rapid international expansion. 


\subsubsection{Managerial implications}

This dissertation provides several important implications for managerial practices. First, for those firms that perform less well, we suggest considering their current strengths and weaknesses to build the most suitable configuration. Our findings indicate that there is no one best way to succeed. Various routes are possible. Therefore, these firms could assess their current level on each type of capabilities and follow the successful pathways presented in the study to achieve higher performance.

Second, for those firms that perform well, this dissertation wants to suggest them to continue with the good practice of capability configurations. Specifically, we suggest these firms to explore how to deploy dynamic bundle of capabilities in other organizational functions to achieve better performance. We recommend managers in these firms to learn from Chapter $\mathbf{3}$ on the existing and potential types of capabilities in EIFs. For example, managers could explore how to develop dynamic bundles in internal administrations and internal resource reconfigurations, since the literature suggests that the effectiveness of organizational administration influence firms' performance (Huselid, Jackson, \& Schuler, 1997). Further, we advise these firms to document their practices, store the knowledge, and make the daily practices as firm routines for training and coaching, since the organization individuals are the foundations of organizational capabilities (Grant, 1996).

Third, a single part of the dynamic bundle is not enough for technology-based EIFs' high performance which asks for dynamic bundles. For instance, in the case analysis above, TikTok achieved rapid international growth with their strong dynamic dandles in technological, international marketing, and international networking. Many EIFs with only one part of the dynamic bundle (e.g., with only the substantive part), are not able to create sustainable advantages and perform well in international markets. Furthermore, for those EIFs in hightech industries, we want to draw their managers' attention on the role of dynamic bundle of technological capabilities: A focus on technological capabilities while neglecting international marketing and networking bundles results in low international performance. Therefore, we advise managers to invest more resources in marketing and networking to build corresponding dynamic bundles of capabilities. 


\subsection{Conclusion and limitations}

To perform well on international markets remains challenging for new ventures. For instance, the sudden outbreak of COVID-19 (Sohrabi et al., 2020) has caused many barriers for EIFs to perform well internationally (Kuckertz et al., 2020). As one new deadly coronavirus (with a $2 \%$ case fatality rate; $\mathrm{Xu}$ et al., 2020), COVID-19 spreads fast and easily among people. As of April 26, 2020, COVID19 has affected 213 countries, infected over 2.8 million people, and caused about 0.2 million deaths worldwide (WHO, 2020a). Governments around the world take a serious of actions to prevent the spread of COVID-19. For example, restricting international travel (Kiernan \& DeVita, 2020), ordering city lockdown and residents quarantine (Crossley \& Williams, 2020), extending holidays (Wu \& Heritage, 2020), and controlling traffics and cancelling mass gathering activities (WHO, 2020b). These measures stopped firms' supply chains, restricted their production and business activities, limited their international logistics, and eventually impede EIFs' high international performance. For example, due to the coronavirus, China's exports dropped by 17.2 per cent, and imports declined by 4 per cent in USD terms in January and February of 2020 (GACC, 2020).

EIFs need dynamic bundles of capabilities to respond to the challenges brought by the coronavirus epidemic on early innovative firms (Kuckertz et al., 2020). For example, this outbreak of COVID-19 highlights the critical roles of dynamic bundle of networking and marketing capabilities in helping EIFs survive and achieve high performance. EIFs face challenges of failure, non-development, and pressure to adapt in this epidemic. To respond to these challenges, EIFs need networking capabilities to get support from business partners, business networks, and brokers (Kuckertz et al., 2020). Also, firms need marketing capabilities to identify and explore entrepreneurial opportunities to develop an extra business model (Kuckertz et al., 2020). With dynamic bundle of networking capabilities, EIFs can secure their supply chains and distribution channels under the situation of worldwide lockdown. With dynamic bundle of marketing capabilities, EIFs can sense and exploit opportunities in international markets to get extra incomes.

This dissertation underlined that capabilities are one of the critical drivers of EIFs' international performance. Research about these capabilities have proliferated rapidly and could be categorized with our model to be more conceptually clarified. Further, the dynamic bundle of capabilities drive EIFs' sustainable comparative advantage, and combinations of several dynamic 
bundles lead to their high international performance. Finally, personal-level capabilities showed no significant effects in driving students' international entrepreneurship intention, and more entrepreneurship education is needed. Our work highlighted the value of applying the configurational perspective to study the early internationalization phenomenon. This dissertation shows that there are different pathways rather than one single way in terms of capability configuration to achieve high international performance in EIFs. We also suggest further questions regarding integrating the configurational perspective into IE study for better understanding EIFs.

Apart from the suggested research questions that we are not able to answer at this moment, this dissertation has the following limitations. Firstly, the limitation relates to the generalizability of findings in the dissertation. Our empirical studies mainly based on a single industry or a single country context. For example, Chapter $\mathbf{4}$ focuses on the high-tech industry in China, and Chapter $\mathbf{5}$ focused on the undergraduates in one technical university in the Netherlands. However, the literature suggests that management practices vary essentially across countries and firms (Bloom \& Van Reenen, 2010). Therefore, comparative studies across countries and industries would help to chart the limits of generalizability. Therefore, we suggest future studies to explore how these findings are different in various industries and various countries.

Secondly, there are several limitations on the methodology side of this work. One limitation is rooted in the research design: because it was not possible to collect more data, we are not able to include other conditions that may be relevant to the model. Conditions could include entrepreneurs' personalities, industrial dynamism, and country-level factors. We advise further research to design a more complete model to have a more comprehensive understanding of EIFs.

Further, the sample size of the two empirical studies is relatively small. The small sample size restricts the possibility to compare the results of QCA analysis and linear analysis, and, therefore, limits the generalizability of our findings. In addition, we used a cross-sectional research design. Thus, we are not able to capture the temporal dynamics of the capability-performance relationship. Therefore, we suggest future studies to design a longitudinal survey to observe the changes in EIFs' capabilities and analyse the evolution of the dynamic bundle configurations. It is of particular interesting to find out how EIFs deal with market dynamisms and how to deploy different capability configurations to achieve performance in dynamic environments. 


\section{References}

Ahmad, S., \& Schroeder, R. G. (2003). The impact of human resource management practices on operational performance: recognising country and industry differences. Journal of Operations Management, 21(1), 19-43. doi:https://doi.org/10.1016/S0272-6963(02)00056-6

Al-Aali, A., \& Teece, D. J. (2014). International Entrepreneurship and the Theory of the (Long-Lived) International Firm: A Capabilities Perspective. Entrepreneurship Theory and Practice, 38(1), 95-116. doi:10.1111/etap.12077

Bai, W., Johanson, M., \& Martín Martín, O. (2017). Knowledge and internationalisation of returnee entrepreneurial firms. International Business Review, 26(4), 652665. doi:10.1016/j.ibusrev.2016.12.006

Baniya, S., Rocha Gaffurri, N. P., \& Ruta, M. (2019). Trade effects of the new silk road: A gravity analysis (English). Retrieved from Washington, D.C. : http://documents.worldbank.org/curated/en/623141547127268639/Trade-

Effects-of-the-New-Silk-Road-A-Gravity-Analysis

Barrett, E. (2020, January 20). A.I. in China: TikTok is just the beginning. Special report on artificial intelligence. Retrieved from https://fortune.com/longform/tiktokapp-artificial-intelligence-addictive-bytedance-china/

Bloom, N., \& Van Reenen, J. (2010). Why do management practices differ across firms and countries? Journal of economic perspectives, 24(1), 203-224. doi:10.1257/jep.24.1.203

Bruderl, J., \& Schussler, R. (1990). Organisational Mortality - the Liabilities of Newness and Adolescence. Administrative Science Quarterly, 35(3), 530-547. doi:10.2307/2393316

Cavusgil, S. T., \& Knight, G. (2015). The born global firm: An entrepreneurial and capabilities perspective on early and rapid internationalisation. Journal of International Business Studies, 46(1), 3-16. doi:10.1057/jibs.2014.62

Crossan, M. M., \& Apaydin, M. (2010). A multi-dimensional framework of organisational innovation: A systematic review of the literature. Journal of Management Studies, 47(6), 1154-1191. doi:https://doi.org/10.1111/j.14676486.2009.00880.x

Crossley, G., \& Williams, A. (2020, January 23). Wuhan lockdown 'unprecedented', shows commitment to contain virus: WHO representative in China. Retrieved from https://www.reuters.com/article/us-china-health-who-idUSKBN1ZM1G9

Davis, J. (2019, June 19). The TikTok strategy: Using AI platforms to take over the world. Retrieved from https://knowledge.insead.edu/entrepreneurship/the-tiktokstrategy-using-ai-platforms-to-take-over-the-world-11776 
Deng, P. (2012). The internationalisation of Chinese firms: A critical review and future research. International Journal of Management Reviews, 14(4), 408-427. doi:10.1111/j.1468-2370.2011.00323.x

Di Stefano, G., Peteraf, M., \& Verona, G. (2014). The organisational drivetrain: A road to integration of dynamic capabilities research. Academy of Management Perspectives, 28(4), 307-327. doi:10.5465/amp.2013.0100

Eisenhardt, K. M., \& Martin, J. A. (2000). Dynamic capabilities: What are they? Strategic Management Journal, 21(10 - 11), 1105-1121. doi:https://doi.org/10.1002/1097-0266(200010/11)21:10/11<1105::AIDSMJ133>3.0.CO;2-E

Fannin, R. (2019). The strategy behind TikTok's global rise. Harvard Business Review, 2019(December 8).

Freeman, J., Carroll, G. R., \& Hannan, M. T. (1983). The liability of newness: Age dependence in organisational death rates. American Sociological Review, 48(5), 692-710. doi:10.2307/2094928

GACC. (2020, March 7). The imports and exports in the first 2 months was RMB 4.12 Trillion (in Chinese). Retrieved from http://www.customs.gov.cn/customs/xwfb34/302425/2879130/index.html

GEM, G. E. M. (2016). Mass entrepreneurship and innovation. Retrieved from https://www.gemconsortium.org/economy-profiles/china\#pb

Ghemawat, P. (2001). Distance still matters. Harvard Business Review, 79(8), 137-147. doi:PMID: 11550630

Grant, R. M. (1996). Prospering in dynamically-competitive environments: Organisational capability as knowledge integration. Organization Science, 7(4), 375-387. doi:10.1287/orsc.7.4.375

Graziani, T. (2019, October 31). Douyin marketing tips - 7 examples of successful Douyin marketing campaigns. Retrieved from https://walkthechat.com/6examples-successful-douyin-marketing-campaigns/

Harms, R., Kraus, S., \& Schwarz, E. (2009). The suitability of the configuration approach in entrepreneurship research. Entrepreneurship \& Regional Development, 21(1), 25-49. doi:10.1080/08985620701876416

Helfat, C. E. (2007). Dynamic capabilities: Foundations. In C. E. Helfat, S. Finkelstein, W. Mitchell, M. Peteraf, H. Singh, D. Teece, \& S. G. Winter (Eds.), Dynamic Capabilities: Understanding Strategic Change in Organisations (pp. 1-18). London: Blackwell Publishing Ltd.

Huselid, M. A., Jackson, S. E., \& Schuler, R. S. (1997). Technical and strategic human resources management effectiveness as determinants of firm performance. Academy of Management Journal, 40(1), 171-188. doi:10.5465/257025

Jia, L., You, S., \& Du, Y. (2012). Chinese context and theoretical contributions to management and organisation research: A three-decade review. Management 
and Organization Review, $8(1), \quad 173-209$. doi:10.1111/j.17408784.2011.00282.x

Johanson, J., \& Vahlne, J. E. (2009). The Uppsala internationalisation process model revisited: From liability of foreignness to liability of outsidership. Journal of International Business Studies, 40(9), 1411-1431. doi:10.1057/jibs.2009.24

Jones, M. V., Coviello, N., \& Tang, Y. K. (2011). International entrepreneurship research (1989-2009): A domain ontology and thematic analysis. Journal of Business Venturing, 26(6), 632-659. doi:https://doi.org/10.1016/j.jbusvent.2011.04.001

Karna, A., Richter, A., \& Riesenkampff, E. (2016). Revisiting the role of the environment in the capabilities-financial performance relationship: A metaanalysis. Strategic Management Journal, 37(6), 1154-1173. doi:10.1002/smj.2379

Kiernan, S., \& DeVita, M. (2020, March 5). Travel restrictions on China due to COVID19. Retrieved from https://www.thinkglobalhealth.org/article/travelrestrictions-china-due-covid-19

Knight, G. A., \& Cavusgil, S. T. (2004). Innovation, organisational capabilities, and the born-global firm. Journal of International Business Studies, 35(2), 124-141. doi:10.1057/palgrave.jibs.8400071

Krasnikov, A., \& Jayachandran, S. (2008). The relative impact of marketing, researchand-development, and operations capabilities on firm performance. Journal of Marketing, 72(4), 1-11. doi:10.1509/jmkg.72.4.1

Kuckertz, A., Brändle, L., Gaudig, A., Hinderer, S., Morales Reyes, C. A., Prochotta, A., .. . Berger, E. S. C. (2020). Startups in times of crisis - A rapid response to the COVID-19 pandemic. Journal of Business Venturing Insights, 13, e00169. doi:https://doi.org/10.1016/j.jbvi.2020.e00169

Li, L. (2018). China's manufacturing locus in 2025: With a comparison of "Made-inChina 2025" and "Industry 4.0". Technological Forecasting and Social Change, 135, 66-74. doi:10.1016/j.techfore.2017.05.028

Martin, S. L., Javalgi, R. G., \& Cavusgil, E. (2017). Marketing capabilities, positional advantage, and performance of born global firms: Contingent effect of ambidextrous innovation. International Business Review, 26(3), 527-543.

Mcdougall, P. P., Shane, S., \& Oviatt, B. M. (1994). Explaining the formation of international new ventures - The limits of theories from international-business research. Journal of Business Venturing, 9(6), 469-487. doi:http://dx.doi.org/10.1016/0883-9026(94)90017-5

Osawa, J., \& Zhang, Y. (2019, June 25). How ByteDance founder is building a global tech giant from China. Retrieved from https://www.theinformation.com/articles/how-bytedance-founder-is-buildinga-global-tech-giant-from-china 
Oviatt, B. M., \& McDougall, P. P. (2005). Defining international entrepreneurship and modeling the speed of internationalisation. Entrepreneurship Theory and Practice, 29(5), 537-553. doi:10.1111/j.1540-6520.2005.00097.x

Parnell, J. A., Lester, D. L., Long, Z., \& Köseoglu, M. A. (2012). How environmental uncertainty affects the link between business strategy and performance in SMEs. Management Decision, 50(4), 546-568. doi:10.1108/00251741211220129

Peteraf, M., Di Stefano, G., \& Verona, G. (2013a). The Elephant in the Room of Dynamic Capabilities: Bringing Two Diverging Conversations Together. Strategic Management Journal, 34(12), 1389-1410. doi:10.1002/smj.2078

Peteraf, M. A., Di Stefano, G., \& Verona, G. (2013b). The elephant in the room of dynamic capabilities: Bringing two diverging conversations together. Strategic Management Journal, 34(12), 1389-1410. doi:10.1002/smj.2078

Puffer, S. M., McCarthy, D. J., \& Boisot, M. (2010). Entrepreneurship in Russia and China: The Impact of Formal Institutional Voids. Entrepreneurship Theory and Practice, 34(3), 441-467. doi:10.1111/j.1540-6520.2009.00353.x

R. Pinho, J. (2011). Social capital and dynamic capabilities in international performance of SMEs. Journal of Strategy and Management, 4(4), 404-421. doi:10.1108/17554251111181034

Schilke, O., Hu, S., \& Helfat, C. E. (2018). Quo vadis, dynamic capabilities? A contentanalytic review of the current state of knowledge and recommendations for future research. Academy of Management annals, 12(1), 390-439. doi:https://doi.org/10.5465/annals.2016.0014

Sjodin, D. R., Parida, V., \& Kohtamaki, M. (2016). Capability configurations for advanced service offerings in manufacturing firms: Using fuzzy set qualitative comparative analysis. Journal of Business Research, 69(11), 5330-5335. doi:10.1016/j.jbusres.2016.04.133

Sohrabi, C., Alsafi, Z., O’Neill, N., Khan, M., Kerwan, A., Al-Jabir, A., . . . Agha, R. (2020). World Health Organization declares Global Emergency: A review of the 2019 Novel Coronavirus (COVID-19). International Journal of Surgery. doi:https://doi.org/10.1016/j.ijsu.2020.02.034

Stenzel, T., \& Frenzel, A. (2008). Regulating technological change-The strategic reactions of utility companies towards subsidy policies in the German, Spanish and UK electricity markets. Energy Policy, 36(7), 2645-2657. doi:https://doi.org/10.1016/j.enpol.2008.03.007

Teece, D. J., Pisano, G., \& Shuen, A. (1997). Dynamic capabilities and strategic management. Strategic Management Journal, 18(7), 509-533. doi:10.1002/(Sici)1097-0266(199708)18:7<509::Aid-Smj882>3.0.Co;2-Z

Waleczek, P., von den Driesch, T., Flatten, T. C., \& Brettel, M. (2019). On the dynamic bundles behind operations management and research and development. European Management Journal, 37(2), 175-187. doi:https://doi.org/10.1016/j.emj.2018.03.005 
Wang, M. L., Qiu, Q., \& Choi, C. H. (2019). How will the Belt and Road initiative advance China's exports? Asia Pacific Business Review, 25(1), 81-99. doi:10.1080/13602381.2018.1525855

WHO, W. H. O. (2020a). Coronavirus disease 2019 (COVID-19): Situation report-97. Retrieved from https://www.who.int/docs/defaultsource/coronaviruse/situation-reports/20200426-sitrep-97-covid19.pdf?sfvrsn=d1c3e800_6

WHO, W. H. O. (2020b). Report of the WHO-China joint mission on coronavirus disease 2019 (COVID-19). Retrieved from https://www.who.int/docs/defaultsource/coronaviruse/who-china-joint-mission-on-covid-19-final-report.pdf

Wilden, R., Devinney, T. M., \& Dowling, G. R. (2016). The architecture of dynamic capability research identifying the building blocks of a configurational approach. Academy of Management annals, 10(1), 997-1076. doi:10.5465/19416520.2016.1161966

Wilden, R., \& Gudergan, S. P. (2014). The impact of dynamic capabilities on operational marketing and technological capabilities: Investigating the role of environmental turbulence. Journal of the Academy of Marketing Science, 43(2), 181-199. doi:10.1007/s11747-014-0380-y

Wu, H., \& Heritage, T. (2020, January 26). China's cabinet to extend Lunar New Year holidays: State broadcaster. Retrieved from https://www.reuters.com/article/uschina-health-holidays/chinas-cabinet-to-extend-lunar-new-year-holidays-statebroadcaster-idUSKBN1ZP0PQ

Wun, L. M. (2019, March 20). How did TikTok become the first Chinese App to succeed oversea? Retrieved from https://walkthechat.com/how-did-tiktok-become-thefirst-chinese-app-to-succeed-oversea/

Xinhua. (2018). China to upgrade mass entrepreneurship and innovation. Retrieved from http://www.xinhuanet.com/english/2018-09/06/c 137450275.htm

Xu, Z., Shi, L., Wang, Y., Zhang, J., Huang, L., Zhang, C., . . . Zhu, L. (2020). Pathological findings of COVID-19 associated with acute respiratory distress syndrome. The Lancet Respiratory Medicine, 8(4), 420-422. doi:10.1016/S2213-2600(20)30076-X

Yamakawa, Y., Khavul, S., Peng, M. W., \& Deeds, D. L. (2013). Venturing from emerging economies. Strategic Entrepreneurship Journal, 7(3), 181-196. doi:10.1002/sej.1158

Yan, X., Gu, D., Liang, C., Zhao, S., \& Lu, W. (2018). Fostering sustainable entrepreneurs: Evidence from China college students' "Internet Plus" innovation and entrepreneurship competition (CSIPC). Sustainability (Switzerland), 10(9). doi:10.3390/su10093335

Zaheer, S. (1995). Overcoming the Liability of Foreignness. Academy of Management Journal, 38(2), 341-363. doi:10.2307/256683 
Zhang, M., \& Hartley, J. (2018). Does guanxi influence product performance and customer loyalty? Journal of Asia Business Studies, 12(3), 233-252. doi:10.1108/JABS-06-2016-0082

Zhou, L., Wu, A., \& Barnes, B. R. (2012). The effects of early internationalisation on performance outcomes in young international ventures: The mediating role of marketing capabilities. Journal of International Marketing, 20(4), 25-45. doi:10.1509/jim.12.0076

Zhou, L. X., Wu, W. P., \& Luo, X. M. (2007). Internationalisation and the performance of born-global SMEs: The mediating role of social networks. Journal of International Business $\quad$ Studies, 38(4), 673-690. doi:10.1057/palgrave.jibs.8400282

Zollo, M., \& Winter, S. G. (2002). Deliberate learning and the evolution of dynamic capabilities. Organization $\quad$ Science, 13(3), 339-351. doi:https://doi.org/10.1287/orsc.13.3.339.2780 
Summary 



\section{Research problem}

Internationalization has been a beneficial strategic option for some young and entrepreneurial firms. However, these early internationalizing firms (EIFs) encounter specific challenges to engage in international competitions. These challenges relate to the liabilities of foreignness and outsidership, as well as EIFs' smallness and newness. Scholars argue that EIFs can evade these challenges with their capabilities. Capabilities are firms' learned and stable pattern of collective activities. Young firms employ capabilities to develop unique products for international markets, and adapt to dynamic international environment under conditions of resource deficiency to create competitive advantages.

However, the proliferation of capability-based research has caused an ambiguity in capabilities' conceptualization. Such ambiguity hinders the development of capability research and provides vague practical implications. Furthermore, existing capability-based literature assumes that one specific capability can determine EIFs' performance. In contrast, literature shows evidence that EIFs perform well in international markets with the combination of several capabilities, which implies capability configurations. This research aims to categorize the existing studied capabilities in EIFs research, and to provide suggestions on how EIFs can improve international performance through the combination of capabilities. Therefore, the research question that guides this research is: What capabilities do young entrepreneurial firms need and how do these firms configure capabilities to achieve high international performance?

\section{Theoretical perspective}

In this research, the capability-based perspective (CBP) is chosen. The CBP literature holds that a firm's heterogeneity in conducting functional-directed behaviours (capabilities) can drive performance differences. Two important classes of capabilities have been addressed in the literature: substantive capabilities and dynamic capabilities. The notion of substantive capabilities involves the performance of administrative, operational, and governance-related functions that allow firms to accomplish tasks in higher quality and with lower cost. The central notion of dynamic capabilities is to sense the change in the environment, formulate a response to the change, then take actions to implement the response. The CBP provides opportunities to understand EIFs' organizational behaviours in international markets, which was recognized as one main research stream in international entrepreneurship study. Better insights into the 
capabilities in international entrepreneurship research will enhance understanding of underlying assumptions of the CBP, thereby providing answers to the research question on how EIFs can achieve high international performance.

\section{Research approach}

This research consists of two systematic literature reviews and two empirical studies. The first literature review takes stock of existing EIFs literature regarding the context of China. Further, this study identifies several knowledge gaps comparing the Chinese EIFs literature with a general IE research framework. This literature review provides suggestions to fill the knowledge gaps and derives a research agenda. The second literature review inventories the existing literature on the topic of capability-international performance in IE research. Based on which, this study provides a categorization model to classify studied capabilities relate to EIFs' international performance. This categorization model offers clear functional boundaries for each capability, therefore, resolves the problem of terming and conceptualizing capabilities with ambiguity. Moreover, this review study contributes to the knowledge of capability-based perspective by providing the foundation of capability configurations.

The research setting for the first empirical study is the high-tech industry in China. This study adopts the set-theoretical perspective to study the capability configuration in Chinese EIFs. A survey is administered on the top management team to assess the capability level among 88 Chinese technology-based EIFs. This study explores the joint relationship of dynamic bundle of capabilities from the configurational approach to account for sample size and causal complexity. The data is analysed with fuzzy-set qualitative comparative analysis (fsQCA). The analysis aims to find configurations of dynamic bundle of capabilities among three functional dimensions (marketing, technology, and networking) that jointly determine EIFs' international performance.

The research setting for the second empirical study is the undergraduates in the University of Twente in the Netherlands. This study applies the theory of planned behaviour framework to study the extent of individual capabilities influencing students' international entrepreneurship intention. A questionnaire survey is conducted among 120 university students. Data is analysed using OLS regression. To test the moderation effects, we use moderated multiple regression. 


\section{Results}

As to the state-of-the-art of Chinese EIFs literature, we found that the Chinese research cluster studied the antecedents, elements, and outcomes of early internationalization. Besides, these studies mainly focus on outcome-driven topics: the majority of these studies focus on analysing the influences from the elements $(53.3 \%)$ and antecedents $(22.2 \%)$ to outcomes. As to the research status of capability-based literature about EIFs' international performance, we found that 73 specific capabilities have been studied, together with 19 actually capability antecedents or consequences. Within these capabilities, 41 of them deal with dynamic capabilities, and 13 of them deal with substantive capabilities. Most of the dynamic capabilities were related to international market observation and evaluation, while most of the substantive capabilities relate to international market operation.

The first empirical study has two significant findings. The first significant finding is that the dynamic bundle of capabilities contributes to EIFs' international performance. Our results showed that in the high-performing EIFs, 9 out of 12 capability bundles are jointly present or absent; meanwhile, in the low-performing EIFs, 7 out of 9 capability bundles are jointly absent or present. Our results indicate that these dynamic bundles of capabilities do not rely on the main effect from specific capabilities (as suggested by linear, regression-based logics), but complement other capabilities contributing to firm performance.

The second significant finding is that we found several pathways to achieve high international performance in terms of capability configurations. Specifically, high-performing EIFs mainly rely on two ways in terms of capability configuration. The first one is the combination of more than two of the marketing, technological, and networking bundles. The second one is the combination of strong networking capabilities; however, with reliable big foreign customers. By contrast, three combinations of capabilities showed their inability to perform well in international markets. These low-performing EIFs showed mainly two clusters of capability configuration. The first one is the absence of all three dynamic bundles. The second one is the presence of only strong technological bundles, but other bundles are absent.

Results from our second empirical study showed that there are no significant direct effects from cultural intelligence and global mindset on international entrepreneurial intention. Moderation analyses suggest a negative, significant 
moderating effect of cultural intelligence on the relationship between personal attitude and international entrepreneurial intention, and on subjective norms and international entrepreneurial intention. Therefore, simply enhancing the global mindset and cultural intelligence does not contribute to students' international entrepreneurial intention. More is required from entrepreneurship education, such as improving the perception of international entrepreneurship as a valuable career choice.

\section{Contributions to theory and practice}

This dissertation extends and refines international entrepreneurship literature and capability-based literature in three ways. First, this research highlights the significant relevance of dynamic bundle of capabilities to EIFs' international performance. Dynamic bundle of capabilities that consists of the substantive and corresponding dynamic capabilities facilitate EIFs to get a sustainable competitive advantage and eventually achieve high international performance. Second, this research refines the capability-based literature by providing a capability categorization model. This model clarified the conceptual boundary of capabilities base on their functions, therefore suggests a solution for solving ambiguity problem in capability conceptualization. Moreover, this research lays a foundation for the configuration among capabilities. Third, this dissertation adds to the capability-based literature by adopting the set-theoretical perspective. There is no only one way that leads to the final goal, multiple ways are possible, and EIFs can select the best pathway that suits them. Furthermore, equifinality in configurations of these capabilities highlights the causal complexity of capability-performance relationship in international entrepreneurship research, which has implications for future conceptual and empirical studies.

For practitioners, this dissertation provides suggestions on how to achieve high international performance through the configuration of capabilities. Two pathways of capability configuration are suggested. The first one is to combine at least two of the marketing, technological, and networking dynamic bundles. The second one is to build a strong dynamic bundle of international networking capabilities, however, with reliable big foreign customers. Technology-based EIFs are suggested to invest in the development of international marketing and international networking capabilities to build corresponding dynamic bundles. 
Nederlanse samenvatting (Summary in Dutch) 



\section{Onderzoeks probleem}

De internationalisering is voor sommige jonge en ondernemende bedrijven een gunstige strategische optie geweest. Deze vroeg internationaliserende bedrijven (EIF's) staan echter voor specifieke uitdagingen om deel te nemen aan internationale wedstrijden. Deze uitdagingen hebben betrekking op de verplichtingen van het buitenland en van buitenstaanders, evenals de kleinschaligheid en het nieuwe karakter van de EIF's. Wetenschappers beweren dat EIF's deze uitdagingen met hun capaciteiten kunnen omzeilen. De capaciteiten zijn het geleerde en stabiele patroon van collectieve activiteiten van bedrijven. Jonge bedrijven maken gebruik van mogelijkheden om unieke producten voor internationale markten te ontwikkelen en zich aan te passen aan een dynamische internationale omgeving onder omstandigheden met een tekort aan middelen om concurrentievoordelen te creëren.

De snelle toename op capaciteiten gebaseerd onderzoek heeft echter geleid tot een dubbelzinnigheid in de conceptualisering van capaciteiten. Een dergelijke dubbelzinnigheid belemmert de ontwikkeling van vermogensonderzoek en biedt vage praktische gevolgen. Bovendien gaat de bestaande op capaciteit gebaseerde literatuur ervan uit dat één specifieke capaciteit de prestaties van EIF's kan bepalen. Uit literatuur blijkt daarentegen dat EIF's goed presteren op internationale markten met de combinatie van verschillende mogelijkheden, wat capaciteitsconfiguraties impliceert. Dit onderzoek heeft tot doel de bestaande bestudeerde capaciteiten in het EIF-onderzoek te categoriseren en suggesties te geven over hoe EIF's de internationale prestaties kunnen verbeteren door de combinatie van capaciteiten. De onderzoeksvraag is dan ook leidraad voor dit onderzoek: welke capaciteiten hebben jonge ondernemers nodig en hoe configureren deze bedrijven capaciteiten om hoge internationale prestaties te behalen?

\section{Theoretisch perspectief}

In dit onderzoek is gekozen voor het competentiegericht perspectief (CBP). De CBP-literatuur stelt dat de heterogeniteit van een bedrijf in het uitvoeren van functioneel-gericht gedrag (capaciteiten) prestatieverschillen kan veroorzaken. In de literatuur zijn twee belangrijke klassen van capaciteiten aan bod gekomen: inhoudelijke capaciteiten en dynamische capaciteiten. Het begrip inhoudelijke capaciteiten omvat het uitvoeren van administratieve, operationele en bestuursgerelateerde functies die bedrijven in staat stellen om taken van hogere 
kwaliteit tegen lagere kosten uit te voeren De centrale notie van dynamische capaciteiten is het aanvoelen van de verandering in de omgeving, het formuleren van een reactie op de verandering en vervolgens het nemen van acties om de reactie te implementeren. Het CBP biedt mogelijkheden om het organisatiegedrag van EIF's op internationale markten te begrijpen, dat werd erkend als een van de belangrijkste onderzoeksstromen in internationaal ondernemerschap. Een beter inzicht in de mogelijkheden van internationaal onderzoek naar ondernemerschap zal het inzicht in de onderliggende aannames van het CBP vergroten, en daarmee antwoorden geven op de onderzoeksvraag over hoe EIF's hoge internationale prestaties kunnen behalen.

\section{Onderzoeksaanpak}

Dit onderzoek bestaat uit twee systematische literatuuronderzoeken en twee empirische onderzoeken. Het eerste literatuuronderzoek inventariseert de bestaande EIF-literatuur met betrekking tot de context van China. Verder identificeert deze studie verschillende kennishiaten door de Chinese EIFliteratuur te vergelijken met een algemeen IE-onderzoekskader. Dit literatuuronderzoek geeft suggesties om de kennishiaten op te vullen en leidt tot een onderzoeksagenda. Het tweede literatuuroverzicht inventariseert de bestaande literatuur over het onderwerp bekwaamheid-internationale prestaties in IE-onderzoek. Op basis hiervan biedt deze studie een categorisatiemodel om de bestudeerde capaciteiten te classificeren, gerelateerd aan de internationale prestaties van EIF's. Dit categorisatiemodel biedt duidelijke functionele grenzen voor elke capaciteit en lost daarmee het probleem van de termijnbepaling en de conceptualisering van capaciteiten met ambiguïteit op. Bovendien draagt deze reviewstudie bij aan de kennis van op capaciteiten gebaseerd perspectief door basis te leggen voor capaciteitenconfiguraties.

De onderzoeksinstelling voor de eerste empirische studie is de hightech industrie in China. Deze studie hanteert het set-theoretische perspectief om de capaciteitsconfiguratie in Chinese EIF's te bestuderen. In het topmanagementteam wordt een onderzoek uitgevoerd om het capaciteitsniveau van 88 Chinese technologie-gebaseerde EIF's te beoordelen. Deze studie onderzoekt de gezamenlijke relatie van de dynamische bundel van mogelijkheden van de configuratieve benadering om rekening te houden met steekproefomvang en causale complexiteit. De gegevens zijn geanalyseerd met fuzzy-set kwalitatieve vergelijkende analyse (fsQCA). De analyse is gericht op het vinden van configuraties van een dynamische bundel van mogelijkheden 
tussen drie functionele dimensies (marketing, technologie en netwerken) die gezamenlijk de internationale prestaties van EIF's bepalen.

De onderzoeksomgeving voor de tweede empirische studie zijn de studenten van de Universiteit Twente in Nederland. Deze studie past de theorie van het geplande gedragskader toe om de omvang van individuele capaciteiten te bestuderen die de internationale ondernemingsintentie van studenten beïnvloeden. Er wordt een enquête gehouden onder 120 universitaire studenten. Gegevens worden geanalyseerd met behulp van OLS-regressie. Om de matigingseffecten te testen, gebruiken we gemodereerde meervoudige regressie.

\section{Resultaten}

Wat betreft de state-of-the-art van de Chinese EIF-literatuur, vonden we dat het Chinese onderzoekscluster de antecedenten, elementen en resultaten van de vroege internationalisering bestudeerde. Daarnaast richten deze studies zich vooral op resultaatgerichte onderwerpen: het merendeel van deze studies richt zich op het analyseren van de invloeden van de elementen $(53,3 \%)$ en antecedenten $(22,2 \%)$ op uitkomsten. Wat betreft de onderzoeksstatus van de op capaciteiten gebaseerde literatuur over de internationale prestaties van EIF's, ontdekten we dat 73 specifieke capaciteiten zijn bestudeerd, samen met 19 feitelijke capaciteitenantecedenten of consequenties. Binnen deze capaciteiten gaat het in 41 gevallen om dynamische capaciteiten en in 13 gevallen om inhoudelijke capaciteiten. De meeste dynamische capaciteiten hebben betrekking op internationale marktobservatie en -evaluatie, terwijl de meeste inhoudelijke capaciteiten betrekking hebben op internationale marktwerking.

De eerste empirische studie heeft twee significante bevindingen. De eerste significante bevinding is dat de dynamische bundel van capaciteiten bijdraagt aan de internationale prestaties van EIF's. Uit onze resultaten bleek dat in de goed presetende EIF's 9 van de 12 capaciteitsbundels gezamenlijk aanwezig of afwezig zijn; in de slecht presterende EIF's zijn 7 van de 9 capaciteitsbundels gezamenlijk aanwezig of afwezig. Onze resultaten geven aan dat deze dynamische capaciteitsbundels van capaciteiten niet gebaseerd zijn op het belangrijkste effect van specifieke capaciteiten (zoals gesuggereerd door lineaire, op regressie gebaseerde logica), maar een aanvulling vormen op andere capaciteiten die bijdragen aan sterke prestaties.

De tweede belangrijke bevinding is dat we verschillende trajecten hebben gevonden om hoge internationale prestaties te behalen in termen van 
capaciteitsconfiguraties. In het bijzonder vertrouwen hoog presterende EIF's voornamelijk op twee manieren in termen van capaciteitsconfiguratie. De eerste is de combinatie van meer dan twee van de marketing-, technologische en netwerkbundels. De tweede is de combinatie van sterke netwerkmogelijkheden; echter met betrouwbare grote buitenlandse klanten. Drie combinaties van capaciteiten toonden daarentegen hun onvermogen om goed te presteren op internationale markten. Deze slecht presterende EIF's vertoonden hoofdzakelijk twee clusters van capaciteitsconfiguratie. De eerste is de afwezigheid van alle drie de dynamische bundels. De tweede is de aanwezigheid van alleen sterke technologische bundels, maar andere bundels ontbreken.

De resultaten van onze tweede empirische studie toonden aan dat er geen significante directe effecten zijn van culturele intelligentie en de mondiale mentaliteit op de internationale ondernemersintentie. Moderatieanalyses suggereren een negatief, significant modererend effect van culturele intelligentie op de relatie tussen persoonlijke houding en internationale ondernemingsintentie, en op subjectieve normen en internationale ondernemingsintentie. Daarom draagt het simpelweg verbeteren van de wereldwijde mentaliteit en culturele intelligentie niet bij aan de internationale ondernemersintentie van studenten. Er is meer nodig van het ondernemerschapsonderwijs, zoals het verbeteren van de perceptie van internationaal ondernemerschap als een waardevolle beroepskeuze.

\section{Bijdragen aan theorie en praktijk}

Dit proefschrift breidt uit en verfijnt internationale literatuur over internationaal ondernemerschap en literatuur op basis van bekwaamheid op drie manieren. Ten eerste benadrukt dit onderzoek de significante relevantie van de dynamische bundeling van capaciteiten voor de internationale prestaties van EIF's. Een dynamische bundeling van capaciteiten die bestaat uit de inhoudelijke en corresponderende dynamische capaciteiten, vergemakkelijken EIF's om een duurzaam concurrentievoordeel te behalen en uiteindelijk hoge internationale prestaties te behalen. Ten tweede verfijnt dit onderzoek de op capaciteiten gebaseerde literatuur door het aanbieden van een capaciteitencategorisatiemodel. Dit model verduidelijkt de conceptuele grens van capaciteiten op basis van hun functies, en suggereert daarom een oplossing voor het oplossen van ambiguïteitsproblematiek in capaciteitsconceptualisatie. Bovendien legt dit onderzoek een basis voor de configuratie van capaciteiten. Ten derde draagt dit proefschrift bij aan de op capaciteit gebaseerde literatuur door het settheoretische perspectief te gebruiken. Er is niet slechts één manier die naar het 
uiteindelijke doel leidt, er zijn meerdere manieren mogelijk en EIF's kunnen het beste pad kiezen dat bij hen past. Bovendien benadrukt de gelijkwaardigheid in configuraties van deze capaciteiten de causale complexiteit van de relatie tussen capaciteit en prestatie in internationaal onderzoek naar ondernemerschap, wat implicaties heeft voor toekomstige conceptuele en empirische studies.

Voor praktijkmensen biedt dit proefschrift suggesties voor het bereiken van hoge internationale prestaties door middel van de configuratie van capaciteiten. Er worden twee mogelijkheden voor capaciteitsconfiguratie voorgesteld. De eerste is het combineren van ten minste twee van de dynamische marketing-, technologische en netwerkbundels. De tweede is het opbouwen van een sterke dynamische bundel van internationale netwerkmogelijkheden, echter met betrouwbare grote buitenlandse klanten. 
About the author 
Early Internationalizing Firms' Capabilities

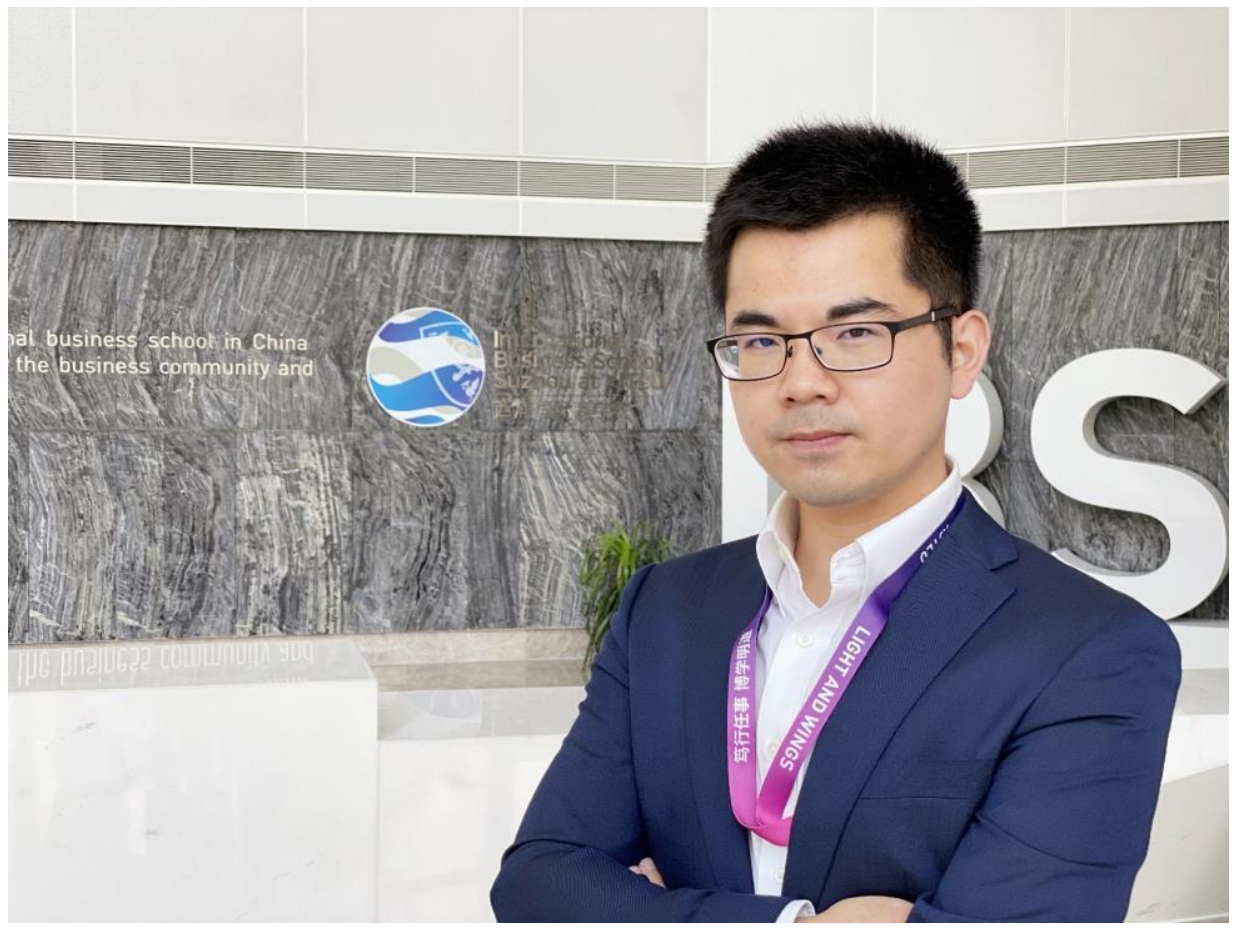


Shuijing Jie was born on June 6, 1991, in Jiangxi province, China. He obtained a Bachelor degree of Economics in International Economy and Trading (2012), and a Master degree of Economics in Industrial Economics (2015) from China University of Mining and Technology (CUMT) in Xuzhou.

In September 2015, Shuijing joined a 4-year external PhD project at NIKOS of the University of Twente, which was funded by China Scholarship Council $(C S C)$. During this project, Shuijing was under the supervision of prof. dr. Aard Groen (Entrepreneurship, Innovation \& Technology Management), and dr. Rainer Harms (Entrepreneurship, Strategy and Innovation Management).

Shuijing's research focuses on international entrepreneurship. Part of his $\mathrm{PhD}$ research was published in the journal of Education Research International. $\mathrm{He}$ has presented his work research several times at top-tier international academic conferences in the field. For example, the annual meeting of the Academy of Management (AOM) and the annual meeting of the European Academy of Management (EURAM).

In August 2020, Shuijing Jie obtained a position as a Senior Lecturer (Assistant Professor) at the department of Strategic Management \& Organization (SMO) in International Business School of Suzhou, Xi'an Jiaotong Liverpool University (XJTLU). 
Early Internationalizing Firms' Capabilities 
Acknowledgement 
Early Internationalizing Firms' Capabilities 
Finally, my $\mathrm{PhD}$ project is about to finish in the time of coronavirus quarantine. I wish to thank all the people whose assistance was a milestone in the completion of this project.

In the first place, I would like to acknowledge financial support from the China Scholarship Council (CSC). Without CSC's financial support, I would have no chance to come to the Netherlands and finish my $\mathrm{PhD}$. Accordingly, I want to thank all diligent Chinese taxpayers behind the council that makes the support possible. Further, I would like to express my sincere appreciation to my supervisor team. I would like to thank my promoter: Prof. dr. Aard Groen, who gave me the admission and accepted me as a member of NIKOS. Although we did not meet so frequently, I still would like to thank for your guidance and promotion during my $\mathrm{PhD}$ project. I wish to express my sincere appreciation to my daily supervisor: dr. Rainer Harms. He convincingly guided and encouraged me to be professional and do the right thing, even when the road got tough. Without his persistent help, the goal of this project would not have been realized. I would like to offer my special thanks to Prof. dr. ir. Petra De Weerd - Nederhof. Although you are not a member of my supervisor team, thank you for the mediating work you have done between my supervisor team and me to make this project continues. Also, thank you very much for providing generous financial support on my research travel and academic communication. Furthermore, I want to express my acknowledgement to some colleagues. Thanks dr. ir. Sandor J.A. Löwik, for inspiring me on the methodology part, and your patient and friendly conversion with me from time to time. Gave me some confidence in continuing the research. Thanks dr. Martin Stienstra, for your early introduction and supports on collecting data from the students in the class. Thanks Prof. dr. Isabella Hatak, for giving your constructive comments on my paper at the new year eve. You will always be remembered as an academic model. Thanks dr. Ir. Tijs Van Den Broek, for helping me with my first paper, and your thesis has inspired me to be a good researcher. Thanks dr. Ir. Haibo Zhou for making connections in my process of finding positions.

And I wish to acknowledge the help from other members of NIKOS: dr. Michel Ehrenhard, dr. Katarzyna Zalewska, dr. Edwin Weesie, dr. Ingrid Wakkee, dr. Ir. Jeroen Kraaijenbrink, dr. Raja Singaram, ir. Jann Van Benthem, dr. Arjan Frederiks, ir. Jeroen Sempel, Annemarie Ridder, dr. Liqin Ren, dr. Tamara Oukes, dr. Efthymios Constantinides, dr. Raymond Loohuis, dr. Jack Jia, Prof. Paula Danskin Englis, and Prof. Basil Englis. Thank you for the help in fitting 
me into NIKOS. Special thanks to the secretaries: Monique Zuithof-Otten, Daniëlle Boelen-Tanke, and Joyce Jagt-Holsbeeke. Thanks for your supports on my research work, which makes my life in the Netherlands much easier. Special thanks to Hester Ter Horst, for your contribution to the translation of the summary of this thesis.

Many thanks to my PhD colleagues: dr. Igors Skute, drs. ir. Koen Kuijpers, Lisa Bakir, Xander Stegehuis, Hanna Hanna, and dr. Anna Priante. Thanks for sharing your lunch time with me which improved my oral English and communication skills. Also, thanks to Jin Han, Ari Manuhutu, Anders Felipe Camargo Benavides, Yasin Sahhar, Timo Fiorito, and Ir. Björn Kijl, thanks for the time of workshop and conference time together. I also want to thank the smart guys from the supply management group: dr. Frederik Vos, dr. Remco Siebelink, and Vincent Delke, the coffee time and the beer will be remembered.

Many thanks to the committee members: prof. dr. T.A.J. Toonen, prof. dr. ir. L.J.M. Nieuwenhuis, prof. dr. M.R. Kabir, prof. dr. R. Breitenecker, prof. dr. J. Halberstadt, prof. dr. T. Flatten, and dr. H. Roelfsema. Thanks for your time on reading and reviewing my thesis, your comments helped to make the thesis better.

I am very glad to have some friends meet in the Netherlands: dr. Haiqing Ji, dr. Qian Li, dr. Qirong Yao, Shu Zhang, Meng Liu, Yi Liu, dr. Shuqin Cao, dr. Chengliang Liu, Jin $\mathrm{Wu}$, Chaoran Zheng, Qiansong Zhang, and Zhicheng Yang. Thanks for your accompanies that drive the loneliness away. Also, communication with you broaden my knowledge about China and research life in science disciplines. I also want to thanks friends in CUMT for their care and comfort from time to time: Prof. dr. Xiaohui Wen, Prof. dr. Lingyun He, dr. Shengbao Ji, and dr. Ruyi Shi. Thanks for your care from time to time, and your psychological supports to encourage me to finish this work.

In the end, I wish to thank my parents for their support and encouragement throughout my study. Thanks for their selfless help, care, and support all the time.

Shuijing Jie

Enschede, the Netherlands

June, 2020 
